\title{
Rechten van patienten bij overdracht van zorg : een gezondheidswetenschappelijk onderzoek
}

Citation for published version (APA):

Klop, R. (1990). Rechten van patienten bij overdracht van zorg : een gezondheidswetenschappelijk onderzoek. [Doctoral Thesis, Maastricht University]. Rijksuniversiteit Limburg. https://doi.org/10.26481/dis.19900601rk

Document status and date:

Published: 01/01/1990

DOI:

10.26481/dis.19900601rk

Document Version:

Publisher's PDF, also known as Version of record

\section{Please check the document version of this publication:}

- A submitted manuscript is the version of the article upon submission and before peer-review. There can be important differences between the submitted version and the official published version of record.

People interested in the research are advised to contact the author for the final version of the publication, or visit the DOI to the publisher's website.

- The final author version and the galley proof are versions of the publication after peer review.

- The final published version features the final layout of the paper including the volume, issue and page numbers.

Link to publication

\footnotetext{
General rights rights.

- You may freely distribute the URL identifying the publication in the public portal. please follow below link for the End User Agreement:

www.umlib.nl/taverne-license

Take down policy

If you believe that this document breaches copyright please contact us at:

repository@maastrichtuniversity.nl

providing details and we will investigate your claim.
}

Copyright and moral rights for the publications made accessible in the public portal are retained by the authors and/or other copyright owners and it is a condition of accessing publications that users recognise and abide by the legal requirements associated with these

- Users may download and print one copy of any publication from the public portal for the purpose of private study or research.

- You may not further distribute the material or use it for any profit-making activity or commercial gain

If the publication is distributed under the terms of Article $25 \mathrm{fa}$ of the Dutch Copyright Act, indicated by the "Taverne" license above, 


\section{RECHTEN VAN PATIENTEN BIJ OVERDRACHT VAN ZORG}

een gezondheidswetenschappelijk onderzoek 


\section{RECHTEN VAN PATIENTEN BIJ OVERDRACHT VAN ZORG}

een gezondheidswetenschappelijk onderzoek

\section{PROEFSCHRIFT}

ter verkrijging van de graad van doctor aan de Rijksuniversiteit Limburg te Maastricht, op gezag van de Rector Magnificus, Prof. Dr. F.I.M. Bonke, volgens het besluit van het College van Dekanen, in het openbaar te verdedigen op vrijdag, 1 juni 1990 om 14.00 uur

door

\section{Renata Klop}

geboren te Amsterdam in 1960 
Promotores: $\quad$ Prof. Mr. F.C.B. van Wijmen

Prof. Dr. H. Philipsen

Beoordelingscommissie: Prof. Dr. A. Knotmerus (voorzitter)

Prof. Dr. A van den Bergh-Braam

Prof. Dr. A. Casparie

Prof. Dr. H. ten Have

Prof. Dr. H. Leenen

CIP-GEGEVENS KONINKLIJKE BIBLIOTHEEK, DEN HAAG

Klop, Renata

Rechten van patiënten bij overdracht van zorg : een gezondheidswetenschapppelijk onderzoek / Renata Klop.

Maastricht : Datawyse. - IIl.

Proefschrift Maastricht. - Met lit. opg.

ISBN 90-5291-024-3

SISO 601.7 UDC[347.15/.17:616-052]](043.3)

Trefw.: patiëntenrecht

Produktie: Datawyse Maastricht, Ruud Leliveld

Vormgeving: Renata Klop

Omslagontwerp: André Kok

Druk: $\quad$ Krips Repro, Meppel

Distributie: Boekhandel De Tribune

Kapoenstraat 8, $6211 \mathrm{KW}$ Maastricht

De druk van dit proefschrift werd financieel mede mogelijk gemaakt door de Jan Dekkerstichting \& Ludgardine Bouwmanstichting en de Stichting Het Scholten-Cordes Fonds 


\section{INHOUDSOPGAVE}

1. INLEIDING 7

1.1 Inleiding 7

1.2 Waarom deze studie? $\quad 12$

1.3 Gezondheidswetenschappelijk perspectief 13

1.4 De gezondheidswetenschappelijke driehoek 15

1.5 Relevante rechten bij overdracht van zorg 18

1.6 Rechten van patiënten nader in kaart gebracht 21

1.7 Indeling van het boek 22

2. METHODOLOGISCHE VERANTWOORDING 25

$2.1 \quad$ Inleiding 25

2.2 De literatururstudie 25

2.3 De interviews 25

2.4 Delphi-methode 28

3. RECHTEN VAN PATIENTEN: JURIDISCH KADER 3I

$3.1 \quad$ Inleiding 31

3.2 Algemene schets 31

3.3 Relevante rechten nader bezien 33

3.3.1 Inleiding 33

3.3.2 Recht op informatie 33

3.3.3 Het toestemmingsvereiste 37

3.3.4 Het recht op vrije keuze 38

3.3.5 Het recht op informationele privacy 39

3.3.6 Het recht op inzage 41

3.3.7 Samenvatting 43

4.

$4.1 \quad$ Inleiding 47

4.2.1 Onderzoeksmethode 47

4.2.2 Selectie van de onderzoekseenheden 49

4.2.3 De interviews 52

4.2.4 Betrouwbaarheid en validiteit 55

4.3.1 Resultaten 60

4.3.2 Recht op informatie 61

4.3.3 Het toestemmingsvereiste 71

4.3.4 Het recht op vrije keuze 75

4.3.5 Het recht op informationele privacy 79

4.3.6 Het recht op inzage 82 
5. DISCUSSIE 89

5.1 Inleiding 89

5.2 Het recht op informatie 89

5.3 Het toestemmingsvereiste 94

$5.4 \quad$ Het recht op wrije keuze 97

$5.5 \quad$ Het recht op informationele privacy 100

5.6 Het recht op inzage 104

5.7 Conclusie 108

6. OPVATTINGEN VAN DESKUNDIGEN OVER

VOORWAARDEN VAN OVERDRACHT VAN ZORG 111

$6.1 \quad$ Inleiding 111

6.2 Delphi-methode 111

6.3 Voorwaarden voor overdracht van zorg 113

$6.4 \quad$ Werkwijze $\quad 114$

6.4.1 De Delphi-rondes 114

6.4.2 De panelselectie 115

6.4.3 Tijdplanning 116

6.4.4 Werkprotocol en aandachtspunten 117

6.5 De analyse 117

6.6.1 Resultaten 118

6.6.2 Resultaten nader toegelicht 119

6.6.2.1 Stellingen waarover consensus is bereikt 119

6.6.2.2 Stellingen waarmee het panel het niet eens is 126

6.6.2.3 Stellingen waarover geen consensus wordt bereikt 129

6.7 Conclusies 133

6.7.1 Conclusies ten aanzien van de resultaten 133

6.7.2 Opvattingen van het panel ten aanzien van rechten en plichten 135

6.7.3 Conclusies ten aanzien van de Delphi-methode 136

7.

7.1

7.2

7.3

BESCHOUWING, CONCLUSIES EN AANBEVELINGEN 139 Beschouwing 139

Conclusies 140

Aanbevelingen 142

LITERATUUR 145

SAMENVATTING 151

SUMMARY 155

DANKWOORD 159

CURRICULUM VITAE 161 


\section{INLEIDING}

\subsection{Inleiding}

In de gezondheidszorg van vandaag krijgt menig patiënt met meer dan éen hulpverlener te maken. De huisarts verwijst naar het ziekenhuis, waar de patiënt zorg ontvangt van onder andere specialist en ziekenhuisverpleegkundige. In de thuissituatie komt aan de zorg naast de huisarts niet zelden de wijkverpleegkundige te pas. Deze opsomming van mogelijkheden, geìnspireerd op de hoofdrolspelers in dit proefschrift, is verre van uitputtend. In zijn gang door de gezondheidszorg gaat, zo zou men kunnen zeggen, de patiënt steeds in andere handen over. Hierbij gaat het om verschillende professies, die verschillende talen spreken, die deels in complexe organisaties werken, waarbinnen en waarbuiten communicatie door allerlei factoren belemmerd wordt. De patiënt - als middelpunt hiervan - verkeert vaak niet in de conditie om in dit netwerk van communicatie een zelfstandige rol te vervullen. Overdracht wan zorg is onder deze omstandigheden waak een probleem.

Dit onderzoek richt zich op rechten van patiënten bij overdracht van zorg. Onder overdracht van zorg wordt in dit onderzoek verstaan de overdracht van verantwoordelijkheid voor de zorg voor een patiënt bij de verwijzing naar en ontslag uit het ziekenhuis. Onderzocht is aan welke voorwaarden het overdrachtsproces dient te voldoen gelet op rechten van patiềnten. In dit onderzoek gaat het om de volgende rechten: informatie, toestemmingsvereiste, vrije keuze, privacy bescherming en inzage.

De nu volgende gevalsbeschrijving geeft een indruk van ervaringen met en opvattingen van betrokkenen over overdracht van zorg. Hiervoor is een selectie gemaakt van enkele passages uit de interviews die in het kader van dit onderzoek zijn gehouden met een patiënt, een huisarts, een wijk- en ziekenhuisverpleegkundige en een specialist rondom een casus'. Alleen de naam van de patient is fictief. Tussen haakjes wordt aangegeven welk recht van de patiënt in het geding is.

\section{Casus 5 eerste interview-ronde}

De heer Dijkstra (86 jaar) woont met zijn vrouw in een grote stad in het westen van Nederland. Op een ochtend krijgt hij het vreselijk benauwd. Zijn vrouw (66 jaar) belt hun huisarts. Deze komt en stelt voor om meneer Dijkstra te laten opnemen in het ziekenhuis.

"Een casus is een in de werkelijkheid voorgevallen overdrachtssituatie, waarbij een patiënt, de verwijzende huisarts, de specialist en ziekenhuisverpleegkundige en na ontslag een wijkverpleegkundige zijn betrokken. In hoofdstuk 4 wordt nader ingegaan op de herkomst van een dergelijke casus en de opbouw van de interviews. 


\section{De heer Dijkstra vertelt:}

"Ik had het wel verwacht, het zat me dwars en benauwd en al die dingen meer.. dus ik verwachtte toch wel dat ik verwezen werd" (informatie verstrekking door huisarts aan patiënt bij verwijzing beperkt).

"In het ziekenhuis heb ik een paar dagen rust gehad en toen ging het weer beter en toen moest ik naar huis. Toen zegt de dokter van ja, je moet naar huis want we nemen geen kostgangers, daar is het veel te druk voor ... nou, toen zeg ik, wat moet ik nou beginnen, dat $\mathrm{kan}$ allemaal niet, mijn vrouw is hartpatiënte en dat kan ze niet volbrengen. Toen zegt de specialist: "maak je eigen daar nou niet bezorgd over, wij hebben al contact opgenomen, morgen krijg je al hulp". Dus toen ik zei dat $\mathrm{ik}$ het niet meer wist hoe het thuis moest na mijn ontslag, toen zei hij: "daar wordt allemaal woor gezorgd, u hoeft u niet bang te maken" (informatieverstrekking door specialist bij ontslag aan patiënt over nazorgmogelijkheden en het ontbreken van het toestemmingsvereiste voor deze zorg).

"Ik vraag nooit wat als het goed gaat. Als het fout gaat zou ik wel wat zeggen" (eigen rol patiënt bij het krijgen wan informatie beperkt).

"lk heb geen idee of de huisarts en de wijkverpleegkundige en de huisarts en de specialist elkaar wel eens bellen" (privacy; patiënt niet geïnformeerd over de professionele informatie-uitwisseling).

\section{De huisarts vertelt:}

"Ik werk hier met vijf, zes huisartsen in de buurt. Wat speelt natuurlijk: zijn ze al ergens bekend, hebben ze al eerder contacten gehad?" (vrije keuze; huisarts houdt bij de verwijzing van een patiënt rekening met vorige ziekenhuiservaringen).

"Soms weten patiënten heel duidelijk wanneer ze ergens niet naar toe willen. Anders maken ze de afspraak niet of zo" (vrije keuze; patiënt mag zelf beslissen of hij verwezen wil worden).

"Soms denk ik, ik moet bij deze patiènt een specialist zoeken waar niet direct een conflict mee ontstaat, die een goed contact kan opbouwen. Dit doe ik om de patiënt met vertrouwen te kunnen verwijzen" (vrije keuze; overwegingen die de huisarts maakt bij het werwijzen van een patiënt).

"Toen ik na ontslag bij de heer Dijkstra was, bleek een wijkverpleegkundige te zijn ingeschakeld. Ik heb wel geprobeerd wijkhulp te bevorderen om zijn vrouw enigszins te ontlasten, omdat ze hartpatiènte is" (ontbreken professionele informatie-overdracht; huisarts niet op de hoogte gebracht van wijkverpleegkundige zorg).

"Vroeger zocht ik specialisten uit waarmee goed overleg mogelijk was. Nu voel ik me deskundig op het gebied van de thuiszorg en verwijs ik patiënten door naar specialisten die ik deskundig acht. Dit heeft overigens wel een poosje geduurd" (vrije keuze; overwegingen die de huisarts maakt bij het verwijzen van een patiënt). 
De wijkverpleegkundige vertelt:

"Als een patiënt, die bij ons in zorg is, wordt opgenonen, dan horen we dat van de patiënt zelf. Maar je hebt ook de kans dat de patiènt onverwachts wordt opgenomen. Dan horen we het van de familie. We laten altijd een kaartje achter met ons telefoonnummer. Ik heb nog nooit meegemaakt dat de huisarts ons informeer-

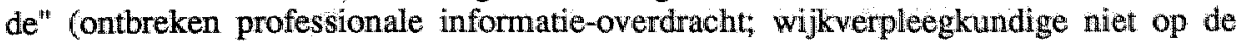
hoogte van opname patiënt).

"Als het goed is wordt het ontslag van een patiënt doorgegeven aan het hoofdkantoor. Ook wordt verteld wat voor hulp de patiënt nodig heeft. Wij. bellen tussen de middag het hoofdkantoor op en om vijf uur nog een keer. Als een patiënt "s morgens thuis is gekomen, dan bellen we deze op als we tijd hebben, tussen de middag of zo en vragen of het goed is dat we even langs komen, welke tijd het beste uitkomt en dan gaan we kijken welke hulp nodig is en hoe vaak. Als het goed is heeft de patiënt dan ook een brief bij zich uit het ziekenhuis, de overdracht" (professionele informatie-overdracht tussen ziekenhuis- en wijkverpleegkundige vindt plaats via hoofdkantoor).

"Als een overdracht niet duidelijk is bel ik nog wel even op. Vaak zijn ze summier geschreven. Staan alleen de klacht en de medicijnen vermeld, daar begin ik niet veel mee. Het hangt niet zozeer van de klacht van de patiënt af, maar meer van degene die het schrijft" (inhoud professionale informatie-overdracht soms niet duidelijk en vindt zowel mondeling als schriftelijk plaats).

"De overdracht wordt altijd aan de patiënt meegegeven. Soms is de brief open, soms dichtgeplakt. Ik lees de brief eerst zelf. Als er lets in staat wat ze zelf nog niet weten, neem ik eerst contact op met het ziekenhuis. Blijkt dat ze van alles op de hoogte zijn, dan laat ik de overdracht gewoon lezen" (inzage in verpleegkundig overdracht-formulier afhankelijk van kennis patiënt over gezondheidstoestand).

"In principe weten patiënten hun diagnose wel altijd, maar ze willen er soms niet over praten. Toevallig heb ik pas meegemaakt dat een mevrouw heel erg was geschrokken van een overdracht die ze had gelezen. Hierin stond dat ze bestrald moest worden. Ze wist niet dat ze kanker had, wel dat de ontsteking weg was gehaald. Ze was helemaal overstuur. $\mathrm{lk}$ heb contact gelegd met de verpleegafdeling. want het was een verpleegkundige overdracht. Ze zeiden dat ze hadden opgeschreven dat ik bij de patiënt eerst maar even moest aftasten.. Ik zeg: "Nee dat staat er niet, en daarbij was de brief open en kon ze het zelf lezen". Toen verbonden ze me door met de chirurg. Toen heb ik voor de patiënt een afspraak gemaakt met de chirurg" (informatie over diagnose bij ontslag onvolledig en hierdoor ontstaan verrassingen voor de patiënt bij inzage in verpleegkundig overdrachtformulier).

"Ik weet niet of patiënten al wettelijk het recht hebben om alles te weten, bijvoorbeeld van wat je opschrijft. Maar mijn gevoel zegt dat ze hier recht op hebben" (inzage in verpleegkundige overdrachtformulieren staat niet als "recht" bekend). 
"Voor de informatie die ik naar het ziekenhuis stuur wraag ik geen toestemming, want vaak zijn patiënten al opgenomen, dus maak je gewoon een overdrachtje" (toestemmingsvereiste voor professionele informatie-overdracht ontbreekt).

"Ik geef patiënten geen advies over bepaalde ziekenhuizen, omdat het vaak oudere patiénten zijn die al bekend zijn in een ziekenhuis. Ze vragen me ook geen advieg'" (het ontbreken van informatie bij verwijzing beperkt vrije keuze patiënt).

\section{De specialist vertelt:}

"Het hangt van de bekendheid van de huisarts af of hij speciaal naar mij verwijst of naar de afdeling" (vrije keuze patiënten afhankelijk van bekendheid huisarts met specialist).

"Er zijn huisartsen die zeggen tegen de patiënt: ga maar een afspraak maken met een longarts en dan kunnen patiënten zelf kiezen. Of er zijn huisartsen die zeggen tegen de patiënt:" ga naar die en die.." (vrije keuze patiënt van specialist bij verwijzing naar het ziekenthuis wordt bepaald door huisarts).

"In het algemeen neem ik contact op met de huisarts als het een onverwachtse diagnose is. Maar ook als ik onvoldoende van de patiënten weet, laat ik het zo zeggen, over de thuissituatie of iets dergelijks. Als we de indruk krijgen dat het toch problemen gaat geven wanneer de patiënt ontslagen wordt" (professionele informatie-overdracht; soms neemt specialist contact op met huisarts).

"Ik denk dat het goed is dat huisartsen patiënten in het ziekenhuis opzoeken. Je hoort het verhaal dan ook van de huisarts zelf" (professionele informatie-overdracht; huisarts bezoekt specialist in het ziekenhuis).

"Het ontslaggesprek gebeurt op zaal en dan worden er bepaalde dingen uitgelegd, zoals medicijngebruik" (informatie specialist aan patiënt bij ontslag).

"Als een patiënt bij ons op de poli op controle komt en ik vind op een gegeven moment dat de toestand stabiel is, dan werwijs ik hen naar de huisarts terug. Het is niet zo dat ik na ontslag, als de patiënt nog bij ons op controle komt, alle medische zorg van de huisarts overneem, zeker niet. Ik beperk me alleen tot de zorg op mijn gebied. Krijgt de patiënt blaasontsteking, dan gaat hij naar de huisarts" (overdracht van verantwoordelijkheid bij overdracht van zorg).

"Ik ken de huisarts van de heer Dijkstra redelijk, ze belt soms op om dingen te overleggen. In dit geval hoefde het niet" (professionele informatie-overdracht tussen huisarts en specialist vindt om verschillende redenen plaats).

"Instinctmatig bekijk ik of mensen het emotioneel aan kunnen. Bij moeilijke gevallen overleg ik met de huisarts. Dan kunnen we het misschien gezamenlijk aanpakken. Soms zegt de huisarts, stuur maar naar huis, dan ga ik haar wel verder begeleiden" (overdracht van zorg betekent soms overdracht van verantwoordelijkheid voor de informatie-verstrekking aan de patiënt). 
"Ik heb zelden meegemaakt dat patiënten om inzage in hun medisch dossier vragen. Je ziet patiënten soms wel stiekum kijken als ze bij de assistente wachten" (patiēnten vragen niet altijd expliciet om inzage).

"De brief van de huisarts vat ik samen als de patiënt vraagt wat erin staat" (informatie van de specialist aan de patiënten over de inhoud van de verwijsbrief van de huisarts).

"Ik heb eigenlijk nooit specifiek toestemming gevraagd voor de informatie die ik doorstuur naar de huisarts. Kijk verwezen, ik onderzoek en kom tot een conclusie en die conclusie wordt uitvoerig met de patiënt besproken, wat mijn bevindingen zijn, wat ik adviseer... Ditzelfde geef ik door aan de huisarts, met wat medische technologie omwikkeld. Dus in feite is er tussen hetgeen ik de patiënt vertel en hetgeen ik de huisarts vertel geen essentieel verschil" (specialist vindt toestemming van de patiënt voor professionele informatie-overdracht geen vereiste).

\section{De ziekenhuisverpleegkundige vertelt:}

"Bij het ontslag overleg je met de patiënt en met de familie wat voor zorg zij denken nodig te hebben en dan......wat we zelf denken en dan schakelen we die instanties in" (vrije keuze van de patiënt voor wijkverpleegkundige zorg).

"Soms laat je een wijkverpleegkundige bij de patiënt thuis komen, zodat die kan bepalen wat voor zorg ze moeten bieden. Er zijn ook mensen bij wie je specifieke zorg moet omschrijven" (overdracht van zorg betekent soms het geven van adviezen/suggesties aan degene aan wie je de zorg overdraagt).

"De brief is in principe open, maar als de patiënt zelf niet weet dat hij een carcinoom heeft en het is ook miet de bedoeling dat ie dat zelf weet om een of andere reden, dan is hij ook gesloten" (patiënten niet altijd gë̈nformeerd over diagnose bij ontslag).

"Ik denk niet dat patiënten hun overdracht lezen, het zijn over het algemeen oudlere patiënten, ik denk het niet" (ziekenhuisverpleegkundige denkt niet dat patiènten behoefte hebben aan inzage).

"Patiënten geven wel toestemming voor het inschakelen van wijkverpleegkundige zorg, niet voor de informatie-overdracht. We vertellen dat de overdracht voor de wijkverpleegkundige bestemd is. Hiervoor geven ze niet expliciet toestemming" (aan patiënten wordt geen toestemming gevraagd voor de professionele informatieoverdracht tussen verpleegkundigen).

"In het begin stond de heer Dijkstra sceptisch ten opzichte van wijkverpleegkundige hulp, maar dat weet ik niet zeker meer. Toen heb ik volgens mij gezegd: "Ze komen om te beginnen thuis en dan kunt u een praatje maken van hoe het gaat en wat uw vrouw eventueel zelf nog kan". Hij had lichamelijke zorg nodig bij het wassen" (vrije keuze patiënten voor wijkwerpleegkundige zorg is beperkt door eigen mogelijkheden). 
In het bovenstaande valt op dat bijna niet gesproken wordt over rechten en plichten bij overdracht van zorg. Toch geven de werschillende passages wel inzicht in de wijze waarop met rechten wan patienten wordt omgegaan. Zo komt onder andere naar voren dat:

- de patient niet weet of en op welke wijze artsen en verpleegkundigen werkzaam in de intra- en extramurale zorg contact met elkaar hebben;

- professionele informatie op verschillende wijze wordt overgedragen;

- de patiênt niet om toestemming wordt gevraagd voor de professionele informatie-overdracht",

- de patient een (beperkte) keuzemogelijkheid van hulpverleners heeft bij opname in en ontslag uit het ziekenhuis;

- de patiënt soms inzage heeft in verwijs- en ontslagbrieven c.q. overdrachtformulieren.

In hoofdstuk 4 zall nader worden ingegaan op de opwattingen en ervaringen van patiënten en en hulpverleners ten aanzien van het overdrachtsproces.

\subsection{Waarom deze studie?}

Overdracht van zorg is een aspect van de hulp aan en de zorg voor patiënten, dat het waard is nader onderzocht te worden. Hier is daarbij het perspectief van de rechtspositie van de patiënt gekozen. Overdracht van zorg betekent overdracht van verantwoordelijkheild voor de zorg van een patiënt. Juist bij de overdracht spelen informatie aan de patiënt en tussen hulpwerleners, beslissingen over doorverwijzing, behandeling, ontslag en nazorg en ook de vertrouwelijke omgang met persoonsgegevens een cruciale rol. De wijze waarop artsen en verpleegkundigen met dergelijke rechten van patiënten omgaan bij overdrachtsprocessen van eerste naar tweede lijn is nog niet systematisch onderwerp van studie geweest. De vraagstelling luidt in dit licht als volgt:

Aan welke voorwaarden dient overdracht van zorg te voldoen gelet op rechten van patiënten?

Bij overdracht van zorg zijn aanhoudend rechten van patiënten en in het geding. Hierbij is het van belang om te weten hoe met deze rechten dient te worden omgegaan in het licht van de (komende) wettelijke regelingen ter zake.

Het onderzoek is opgesplitst in drie delen, te weten:

- een literatuurstudie

- interviews

- een Delphi-methode

Om de vraagstelling te onderzoeken is eerst de rechtspositie van de patiënt aan de hand van wet- en regelgeving, jurisprudentie en zelfregulering bestudeerd. Vervolgens is gebruik gemaakt van sociaal-wetenschappelijke onderzoeksmethoden. De interviews met patiënten, artsen en verpleegkundigen over opvattingen en ervaringen ten aanzien van het overdrachtsproces zijn bedoeld om inzicht te krijgen van de werkelijkheid van enkele overdrachtsprocessen. Met de Delphi-methode zijn de inzichten die zijn verkregen uit de literatuurstudie en de interviews in de vorm van stellingen ter beoordeling voorgelegd aan een panel van deskundigen, om na te 
gaan in hoeverre consensus kan worden bereikt over voorwaarden woor overdracht van zorg. In hoofdstuk 2 wordt nader ingegaan op de methodologische verantwoording van de gevolgde werkwijze.

\section{$1.3 \quad$ Gezondheidswetenschappelijk perspectief}

Dit onderzoek is een gezondheidswetenschappelijke studie. De Stichting voor Medisch Onderzoek en Gezondheidszorgonderzoek (MEDIGON) definieert gezondheidswetenschappen als "die wetenschappen die de invloed bestuderen van omgevingsfactoren, gedragsfactoren en lichamelijke factoren op de gezondheidstoestand van bevolking en individuen, alsmede de wijze waarop vorm en inhoud gegeven kan worden aan de gezondheidszorg. Uitgangspunt voor wetenschappelijk onderzoek is de gezonde en niet de zieke mens".

Ten Have (1987) komt tot de conclusie dat "gezondheidswetenschappen een verbreding betekenen voor de geneeskunde; die laatste heeft in zijn ogen sinds de vorige eeuw zowell wat haar object als wat haar methoden betreft een proces van inperking en specificering ondergaan, zodat een opvatting van geneeskunde als gezondheidsleer, die eeuwenlang vanzelfsprekend was, in onze tijd geen inhoud meer heeft". Volgens hem gaan de gezondheidswetenschappen uit van een positief gezondheidbegrip en niet, zoals in de geneeskunde, van een negatief (afwezigheid van ziekte). "Het negatieve begrip wordt niet afgewezen, maar geëncadreerd in een bredere opvatting. Het surplus van het positieve gezondheidsbegrip ten opzichte van het negatieve is echter op verschillende wijze nader omschreven: als het vermogen om maatschappelijke rollen en functies adequaat te verrichten, als een toestand van volledig lichamelijk, geestelijk en maatschappelijk welzijn, als adaptatie aan de omgeving en als vermogen tot zelfbeschikking. Elk van deze omschrijvingen belicht bepaaldle aspecten van het menselijk functioneren; vanuit een dergelijk gezichtspunt wordt gezondheid onderzoekbaar met de methode van een specifieke wetenschappelijke discipline"" (Ten Have 1987).

Het bovenstaande geeft een algemeen-typologische benadering weer en verdient daarom enige nuancering. Hoe "curatiever" de zorg des te meer zal de ziekte als zodanig centraal staan. Het is dan ook waarschijnlijk dat hulpverleners die sterk. gespecialiseerde zorg verlenen meer een negatief gezondheidsbegrip hanteren. Naarmate een beroepsbeoefenaar meer werkzaam is als generalist, bijvoorbeeld als huisarts of wijkverpleegkundige, is het aannemelijk dat meer rekening wordt gehouden met de bedreigende en begunstigende factoren van het gezonde bestaan. Op deze begrippen zal in paragraaf 1.4 nader worden ingegaan.

Vanuit het gezondheidswetenschappelijk perspectief kunnen in het vlak van de directe patiëntenzorg, maar ook in dat van de gezondheidszorg en het gezondheidszorgbeleid oorzaken worden benoemd voor de problematiek rondom overdracht van zorg. Tezamen leidt dat tot een aantal factoren, waarvan de belangrijkste hieronder worden vermeld. 


\section{De afhankelijklheid van de patiënt}

lemand die aangewezen is op hulp uit de gezondheidszorg bevindt zich in een afhankelijke positie. De zojuist geschetste complexiteit van de zorg roept de vraag op wie deze rondom en ten behoeve van de patiënt coördineert. Nadat verschillende hulpwerleners in de eerste lijn deze rol hebben geclaimd, ontstaat een beweging om de patiënt zijn eigen coördinator te laten zijn. In het beeld van de autonome patięnt, waar het recht wan uit gaat, zou dat moeten kunnen. Met alle respect voor het recht stelt Philipsen dat dit in de gezondheidszorg een lapmiddel blijft, zolang men niet erkent dat de meest bewerkelijke patiënten minder vrij en mondig zijn dan de gemiddelde burger. Wanneer men de zelfstandigheid van de patiènt wil benadrukken, dient men deze op te vatten als de autonomie van de patiënt met inbegrip van zijn sociaal netwerk (Philipsen 1985, p. 151). Juristen ijveren daarentegen voor de zelfbeschikking van de patiënt als een individueel recht. $\mathrm{Zij}$ sluiten de ogen niet voor het feit, dat vele patiënten in een afhankelijke positie verkeren. Aan het zelfbeschikkingsprincipe doet dat niets af: patiënten die dat kunnen, moeten mogen beslissen. Zij die dat niet kunnen, verdienen extra bescherming, soms ook tégen het sociaal netwerk. Zolang anderen ${ }_{\text {, }}$ ook al is dat met de beste bedoelingen, voor patiënten beslissen, ijwert de "patiëntenbeweging" terecht voor verdere positivering van rechten en plichten, zonder aan de coördinatie van een behoorlijke, continue zorg te willen tornen (Van Wijmen 1988, p. 28).

\section{De toename van de medische mogelijkheden}

In de jongste decennia zijn de medische mogelijkheden exponentieel toegenomen. Geavanceerde en steeds verfijnder diagnostische technieken stellen ons in staat met steeds grotere nauwkeurigheid ziekte-oorzaken op te sporen. Ook de behandelmethoden worden voortdurend verbeterd. Met behulp van deze medische technologie is het mogelijk om zowel de levensduur te verlengen als de kwaliteit van het leven te verbeteren. Schaduwzijde van deze ontwikkelingen is dat een zo grote hoeveelheid mogelijkheden tot keuzes noopt. Patiënten zijn hier niet altijd toe in staat en voelen zich soms in een uitzichtloze situatie gemanoeuvreerd. In de directe patiëntenzorg in het algemeen en in overdrachtssituaties in het bijzonder trekt dit een zware wissel op aard en inhoud van de informatie aan patiënten en beslissingen omtrent doorverwijzing, behandeling ontslag en nazorg.

\section{De vergrijzing van de bevolking}

In de gehele westerse samenleving ziet men de bevolking vergrijzen. Daarmee nemen langdurige, chronische of degeneratieve aandoeningen en gebreken toe. Dit vraagt om intensievere medische en verpleegkundige hulpverlening in de thuissituatie: ouderen zijn meer op de huisarts aangewezen en het overgrote deel van thuisverpleging betreft de categorie ouderen. Verwijzing naar het ziekenhuis vindt relatief het vaakst in deze categorie plaats. Na zijn verblijf in het ziekenhuis is de oudere veelal nog op medische hulp en verpleegkundige zorg aangewezen.

\section{Het substitutiebeleid van de overheid}

Het overheidsbeleid is gericht op beperking van de intramurale sector ten gunste van de extramurale zorg. Deze substitutie, die een belangrijke pijler vormt van het 
beleid (Rapport-Dekker, Verandering Verzekerd) komt de thuiszorg ten goede. De eerstelijnsgezondheidszorg is evenwel nog onvoldoende op deze nieuwe zorgvraag voorbereid door:

- onevenwichtigheid: de gemiddelde verpleegduur in ziekenhwizen daalt nog steeds, waardoor patiënten sneller ontslagen worden en meer medische en verpleegkundige nazorg nodig hebben; de mogelijkheden in de eerstelijnsgezondheidszorg, zowel in termen van capaciteit als van deskundigheid, blijven daarbij achter;

- onvoldoende steun uit de informele sector: door toenemende individualisering nemen de bereidheid en de mogelijkheid om voor elkaar te zorgen af. Steun door partners en kinderen is vaak niet voorhanden en kan in redelijkheid niet altijd worden gevraagd. Voor de wederzijdse steun door buren en bekenden geldt hetzelfde (Philipsen 1986).

- verschil in scholing: de opleiding van huisartsen en wijkverpleegkundigen is nog onvoldoende toegesneden op de complexe problematiek van de zorg aan ouderen met chronische, degeneratieve ziekten; specialisten en ziekenhuisverpleegkundigen zijn beter geschoold in het verlenen van gedifferentieerde hoogtechnische zorg.

\section{De specialisering in de gezondheidszorg}

De patiënt krijgt steeds meer te maken met verschillende gespecialiseerde hulpverleners en instellingen. Aan de ene kant is dit een positieve ontwikkeling: de patiënt krijgt de beste zorg. Aan de andere kant leidt deze ontwikkeling tot de volgende twee problemen. De gespecialiseerde procedures sluiten niet automatisch aan op de behoeften en gevoelens van de patiènt. Zoals Philipsen (1985) aangeeft dreigt het gevaar dat de ziekte, niet de zieke een "project" wordt waarbij de instrumentele aspecten van het handelen de leefwereld van de patiënt "koloniseren".

Het tweede probleem betreft de communicatie. Door vergaande specialisering wordt het voor hulpverleners steeds moeilijker elkaar te verstaan, terwijl ze in het kader van de behandeling/verzorging/overdracht van zorg juist in toenemende mate met elkaar moeten communiceren.

Aldus leidt de specialisering tot een heterogene en gedifferentieerde gezondheidszorg waarbij hulpverleners extra moeite moeten doen om op de hoogte te zijn van elkaars kwaliteiten en mogelijkheden.

\subsection{De gezondheidswetenschappelijke driehoek}

Kenmerkend voor gezondheidswetenschappen is dat verschillende disciplines (gezondheidsethiek, gezondheidsrecht, medische psychologie, medische sociologie etc.) in hun benadering van gezondheid en gezondheidszorg samengaan en daarbij een gemeenschappelijke theoretische grondslag nodig hebben. Eén van de in dit verband mogelijke theorieën is de op het gezondheidskundig concept van Kuiper (1975) georiënteerde "driehoek", zoals door Philipsen geïntroduceerd (1986).

Volgens deze gezondheidswetenschappelijke benadering kan het thema "overdracht van zorg" gestructureerd worden weergegeven door uit te gaan van de driehoek: 
gezond bestaan, bedreigende en begunstigende factoren en interventies. Verschijnselen van ziekte, gezondheid en gezondheidszorg kunnen vanuit de drie hoekpunten worden bestudeerd, ook met het onderhavige gezichtspunt: de rechten van de patiënt bij overdracht varı zorg. Dit leidt tot wragen als de volgende:

* Welke gezondheidswetenschappelijke problemen doen zich voor?

* Hoe worden ze door patiënten en beroepsbeoefenaren beleefd en gedefinieerd?

* Welke factoren bedreigen of begunstigen het "gezonde bestaan" van het individu? Het gaat daarbij niet on factoren die eventueel bijdragen aan het ontstaan van het gezondheidsprobleem. Aan de orde zijn vooral de factoren die inwerken op het verloop van de ziekte en op de loopbaan van de patiënt.

* Welke interventies vinden in de gezondheidszorg plaats die bijdragen tot een soepele overdracht van zorg? Bestaat er duidelijkheid in verantwoordelijkheden en beslissingen die in het kader van het overdrachtsproces worden genomen?

Schema 1.1 vat het bovenstaande samen.

Deze specifieke invulling van de gezondheidswetenschappeijike driehoek kan als volgt worden toegelicht:

1. Bij het "gezonde bestaan" worden de lichamelijke en geestelijk toestand van de patiënt alsmede zijn maatschappelijk positie en loopbaan niet ongunstig beïnvloed door overdracht van zorg.

2. Overdracht van zorg kan plaats vinden wanneer:

* rechten van patiënten worden gerespecteerd door:

- informatieverstrekking aan de patiënt met betrekking tot:

. keuzemogelijkheden

. het recht op inzage

. de professionele informatie-overdracht

- het vragen van toestemming voor:

. de verwijzing

. de professionele informatie-overdracht

. het inschakelen van een wijkverpleegkundige

* er duidelijkheid bestaat in verantwoordelijkheid bij hulpverleners;

* er duidelijkheid bestaat in beslissingen die in het kader van overdracht van zorg worden genomen;

* er evenwicht bestaat tussen de thuis geboden zorg en de in instellingen geboden zorg;

* coördinatie in de patiëntgebonden zorg de fragmentatie ervan overheerst.

3. Het overdrachtsproces zal soepel verlopen wanneer rekening wordt gehouden met de in de vorige paragraaf genoemde factoren. Dit betekent dat aan de volgende voorwaarden moet worden voldaan:

* de patiënt dient betrokken te worden bij het overdrachtsproces;

* de zorg dient gericht te zijn op langdurige, chronische of degeneratieve aandoeningen die vooral op latere leeftijd voorkomen;

* bij het substitutiebeleid van de overheid dient aandacht te worden geschonken aan een bevredigende thuiszorg;

* specialisering dient plaats te vinden zonder dat dit gepaard gaat met "de kolonisatie van de leefwereld van de patiënt" en communicatie problemen tussen verschillende hulpverleners; 
* goede informatieverstrekking dient plaats te vinden orntrent voor- en nadelen van medische mogelijkheden;

* aan medische mogelijkheden in de gezondheidszorg dient aandacht te worden geschonken.

\section{GEZOND BESTAAN}

* De lichamelijke en geestelijke toestand van de patiént alsmede zijn maatschappelijke positie en loopbaan worden niet ongunstig beïnvloed door overdracht van zorg

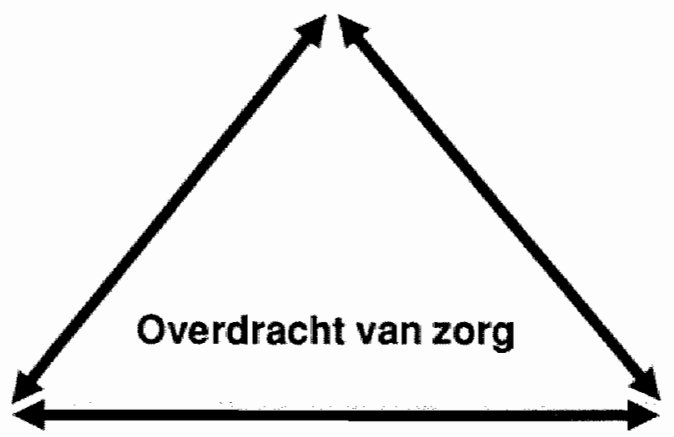

\section{BEDREIGENDE EN \\ BEGUNSTIGENDE FACTOREN}

- Patiënt-kenmerken

-de mate van afhankelijkheid

- de mate van betrokkenheid

- de mate van organisatie

* Gezondheidszorg-kenmerken

- De vergrijzing wan de bevolking

- Het substitutiebeleid van de overheid

\section{INTERVENTIES}

- Respecteren van de rechten van de pallent door: - Informatieverstrokking aan de patient m.b.t.: keuze mogelijkheden recht op inzage professionele informatie-uitwisseling

- Toestemmingsvereiste voor: de verwijzing de prolessionele informatie-overdracht hel inschakelen van oen wijkverpleegkumdige

- Duide lijkheid in verantwoordelijkheid bij beroepsbeoelenaren

* Duidelijkheid in beslissingen die in hat kader van overdracht van zorg worden genomen

* Coórdinatie in plaats van fragmentatie in de patientgebonden zorg

* Evenwicht tussen de thuis aangebonden zorg en de in de inslellingen aangeboden zorg

Schema 1.1 De gezondheidswetenschappelijke driehoek bij overdracht van zorg 
Op welk veld heeft dit onderzoek betrekking? Om te beginnen moet worden opgemerkt dat elk onderzoek in principe met elk van de drie hoeken van de driehoek te maken heeft. Inperking vindt plaats door de keuze van een concreet empirisch vragstuk te koppelen aan een theoretisch/wetenschappelijk uitgangspunt (Philipsen 1986).

Dit onderzoek gaat in op de vraag an welke woorwaarden het overdrachtsproces moet voldoen, zoals deze plaats vindt van de eerste naar de tweede lijn en vice versa. Hierbij vormt het juridisch kader, met in het bijzonder de rechten van de patiënt; het normatief wetenschappelijk uitgangspunt.

\subsection{Relevante rechten bij overdracht van zorg}

Uit de casus, die eerder in het dit hoofdstuk werd beschreven, blijkt dat verschillende rechten van de patiënten een belangrijke rol spelen bij het overdrachtsproces. Hierbij ligt het accent op het recht op informatie, omdat dit recht de patiënt onder andere in staat stelt om toestemming te geven voor de verwijzing en om een keuze te maken naar welk ziekenhuis hij verwezen wil worden. Kortom, informatie stelt de patiënt in staat zijn andere rechten te realiseren, zoals het toestemmingsvereiste, vrije keuze, privacy en inzage.

Naast het toestemmingsvereiste voor de verwijzing is de toestemming van de patiënt ook van belang bij de volgende stappen die in het overdrachtsproces worden gezet. De patiënt heeft weliswaar een overeenkomst gesloten met zijn huisarts, maar voor de handelingen die binnen deze overeenkomst worden verricht is telkens de toestemming van de patiënt vereist. Toestemming voor de verwijzing is in het bijzonder van belang omdat de behandeling tussen huisarts en patiënt bij opname in het ziekenhuis tijdelijk onderbroken wordt.

Met een variatie op het begrip "informed consent" kan bij verwijzing naar het ziekenhuis gesproken worden van "informed referral" en bij ontslag van "informed discharge". Dit betekent overigens niet dat de informatie zich moet beperken tot die informatie die de patiénten in staat stelt toestemming te geven. Ook als geen toestemming in het geding is dient de patiënt deugdelijk te worden geïnformeerd. Wat dit betekent voor de inhoud van de informatie bij overdracht van zorg, wordt nader beschreven in hoofdstuk 3.

Het recht op vrije keuze speelt een rol als de huisarts tot de conclusie komt dat een verwijzing naar een specialist gewenst is. In de casus blijkt dat de huisarts zelf enige overwegingen heeft bij de keuze van een specialist of ziekenhuis. Bij elke stap in het overdrachtsproces is er sprake van een keuze moment, ook voor de patiënt. Soms is de patiënt zelf niet in staat om te kiezen bij de verwijzing naar het ziekenhuis - een comateuze patiënt heeft weinig te kiezen bij verwijzing naar het ziekenhuis - en soms zijn de keuzemogelijkheden beperkt door de organisatie van de gezondheidszorg. In hoofdstuk 3 wordt aangegeven binnen welke grenzen de patiënt bij overdracht van zorg recht heeft op vrije keuze. 
Het recht op privacy komt in de casus niet duidelijk naar voren, maar speelt toch een belangrijke rol bij het overdrachtsproces. Het gaat hier om de informationele privacy, waaronder ook het recht op geheim wordt genoemd. Overdracht van zorg gaat namelijk gepaard met het uitwisselen van informatie tussen bercepsbeoefenaren. Deze professionele informatie-uitwisseling is nodig om de continuüteit in de zorg te garanderen en om op een verantwoorde wijze de zorg van een patiènt over te kunnen dragen. Uiteraard heeft de patiënt het recht dat met deze informatie zorgvuldig wordt omgesprongen.

Tenslotte is het recht op inzage bij overdracht van zorg van belang. De patiënt zal behoefte aan inzage kunnen hebben in zijn verwijs- en ontslagbrieven c.q. overdrachtformulieren om erachter te komen wat hij nu precies heeft. Deze behoefte hoeft in eerste instantie niet te berusten op gebrek aan vertrouwen in de beroeps: beoefenaar, maar kan ook voortkomen uit een soort nieuwsgierigheid. Uiteraard kan de patiënt de behoefte hebben om gegevens in de professionele informatieoverdracht te corrigeren, te verwijderen en/of aan te vullen, al zal dat dit meestal niet de reden zijn waarom hij om inzage verzoekt. In hoofdstuk 3 wordt aangegeven wie inzage kan verstrekken en in hoeverre de patiënt de mogelijkheid heeft tot correctie, verwijdering en aanvulling.

In dit onderzoek zal niet specifiek worden ingegaan op de rechten van de minderjarige patiënt en de rechten van de patiënt die geestelijk is belemmerd zijn eigen belangen te behartigen en zelf beslissingen te nemen over een medische behandeling en verzorging. Deze patiëntencategorieën zouden te veel afzonderlijke uitleg vergen van bijzondere rechtsconstructies, die voor overdracht van zorg als zodanig niet van belang zijn. We beperken ons dus tot de rechten van de meerderjarige, handelingsbekwame patiënt.

Samenvattend, de volgende rechten van patiënten worden in dit onderzoek betrokken: het recht op informatie, het toestemmingsvereiste, het recht op vrije keuze, het recht op informationele privacy en het recht op inzage.

Bovenstaande rechten in het overdrachtsproces kunnen als volgt schematisch worden weergegeven (schema 1.2). 


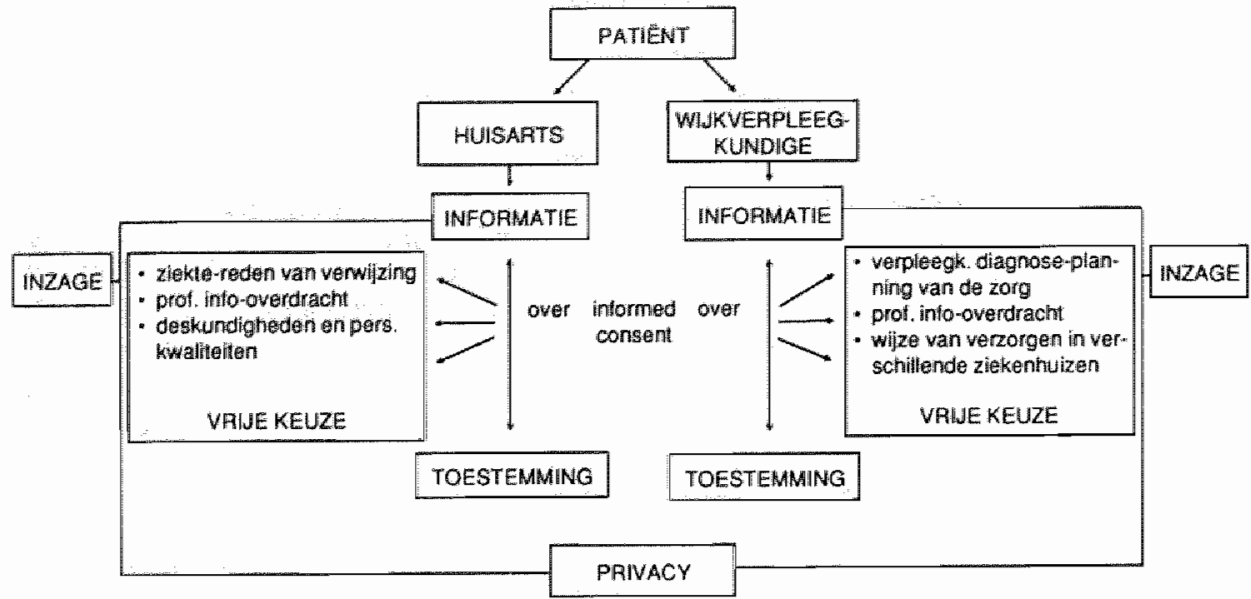

\section{Informed Referral}

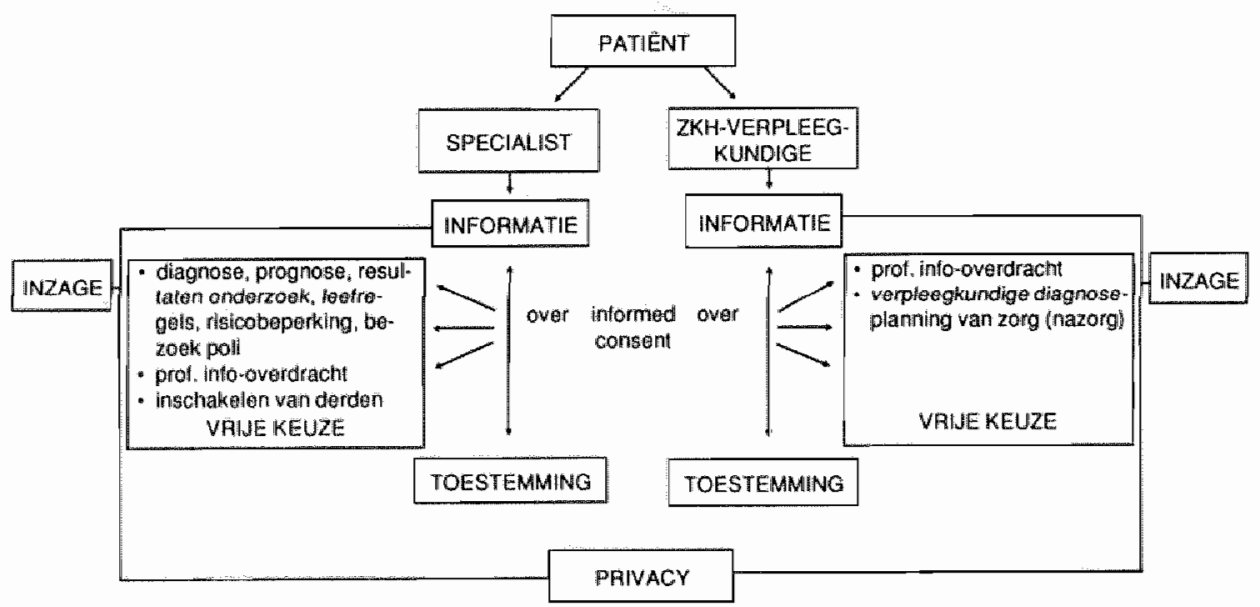

\section{Informed discharge}

Schema 1.2 De vijf rechten van de patiënt bij "informed referral" (verwijzing) en "informed discharge $^{\text {th }}$ (ontslag) 


\subsection{Rechten van patiënten nader in kaart gebracht}

Voor de zes overdrachtssituaties in de tweede ronde ${ }^{2}$, die wij via de interviews op het spoor kwamen, kan in een schema (1.3) worden aangegeven op welke wijze artsen en verpleegkundigen volgens de patiënt met de eerder aangeduide rechten zijn omgegaan.

\begin{tabular}{|c|c|c|c|c|c|c|c|c|c|}
\hline & & & casus & 1 & 2 & 3 & 4 & 5 & 6 \\
\hline \multirow{9}{*}{ 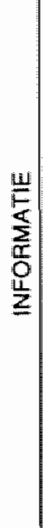 } & \multirow{5}{*}{ 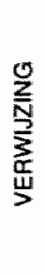 } & - met betrekking lol ziekte-reden vermigzing (huisarts) & & $x$ & $x$ & $X$ & $x$ & $x$ & $x$ \\
\hline & & \multirow{2}{*}{ - met betrekking tot prolessionele inilormatie overdracht o 0} & ha & $?$ & $x$ & $x$ & $?$ & $?$ & $?$ \\
\hline & & & $w$ & M.V.l. & - & n.y.t. & 7 & n. & n.v.t. \\
\hline & & $\begin{array}{l}\text { - met betrekking tot deskundigheden en persaonlifike kwalitei- } \\
\text { tem specialistziekenhuis (huissants) " }\end{array}$ & & - & - & - & - & - & - \\
\hline & & $\begin{array}{l}\text { - met betrekling tot wijze van verzongen in verschillende zio- } \\
\text { kenhuizen (wi kverpleeghumdige) }\end{array}$ & & m.y.t. & - & n.t.t & - & n.u.t. & m.v.t. \\
\hline & \multirow{4}{*}{$\frac{0}{5}$} & $\begin{array}{l}\text { met betrekking tot diagnose, prognose, resultaten onder- } \\
\text { zoek, leeflregels, risicobeperking, bezoelk polkiliniek } \\
\text { (spectialist) }\end{array}$ & & $\cdots$ & 0 & $x$ & $x$ & 0 & - \\
\hline & & - met betrakina tot orofessionele linfom ate-ourdracht to & spect & 0 & $\mathrm{x}$ & 7 & $=$ & $\therefore$ & $?$ \\
\hline & & 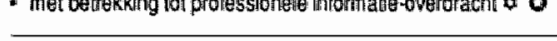 & 2. werpl & $\cdots$ & 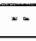 & ninti. & 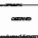 & $?$ & $?$ \\
\hline & & " met betrekking bot inschakelein wijkverpleegkundige " & & $\cdots$ & $x$ & n.v.t. & $x$ & $?$ & 0 \\
\hline
\end{tabular}

\begin{tabular}{|c|c|c|c|c|c|c|c|c|c|}
\hline \multirow{10}{*}{ 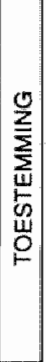 } & \multirow{5}{*}{ 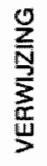 } & \multicolumn{2}{|l|}{ " woor de verwijzing " } & \multirow{2}{*}{-} & \multirow{2}{*}{-} & \multirow{2}{*}{-} & \multirow{2}{*}{-} & \multirow{2}{*}{-} & \multirow{2}{*}{-} \\
\hline & & & ha & & & & & & \\
\hline & & 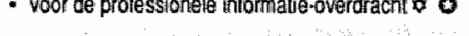 & w. verpl & $\cdots$ & $\cdots$ & n.v.t. & $\cdots$ & n.vil. & $-\infty$ \\
\hline & & \multirow{2}{*}{ - wasteggen loestemming 0} & & $\cdots$ & $\because$ & $\therefore$ & $\therefore *$ & 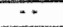 & $\therefore$ \\
\hline & & & & + & $\cdots$ & $=$ & $m-$ & $\cdots$ & $\cdots$ \\
\hline & \multirow{5}{*}{$\frac{0}{\frac{O}{Z}}$} & " woor inschakelen wijkverpleegkundige " & & $\cdots$ & $\cdots$ & nu.r.t. & $\cdots$ & $?$ & - \\
\hline & & & hà & $\therefore$ & $\cdots$ & $\therefore-\infty$ & $\therefore$ & $\cdots$ & $\therefore$ \\
\hline & & - woor de prolessionele inlomalie-owerdrachl o & w. Wepl & $\therefore$ & $\because$ & n. & $\because$ & $?$ & $\cdots$ \\
\hline & & * katyegonen toestemming 0 & & $x=$ & $\sim$ & $\therefore$ & $\cdots$ & 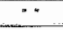 & 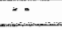 \\
\hline & & & & $\cdots$ & $\cdots$ & n.M. & $\cdots$ & $\because$ & + \\
\hline & & $\begin{array}{l}0 \text { = piwacy } \\
\text { = wilie keuze } \\
\text { w inzage }\end{array}$ & \multicolumn{7}{|c|}{ 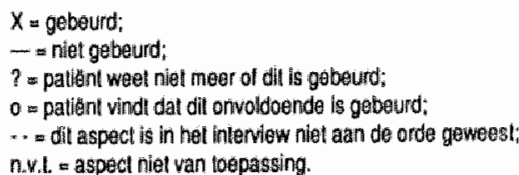 } \\
\hline
\end{tabular}

Schema 1.3 Rechten van patiënten nader in kaart gebracht aan de hand van de interviews met patiënten over 5 overdrachtsprocessen.

${ }^{2}$ De interviews zijn gehouden in twee rondes. Op grond van de resultaten uil de eerste interview ronde zijn in de tweede ronde interviews gehouden aan de hand van topics. In hoofdstuk 4 wordt nader ingegaan op de opbouw van de interviews. 
Hierbij dient te worden opgemerkt dat deze gegevens niet te generaliseren zijn naar een algemeen overdirachtsproces. Het schema vormt slechts een illustratie ter verbeelding van de werkelijkheid, zoals wij die in dit onderzoek antroffen.

Uit dit schema blijkt dat de patiënten in de verschillende casus aangeven dat de informatie zich met name beperkt tot de informatieverstrekking door de huisarts over respectievelijk de ziekte en reden van de verwijzing en de - veelal gebrekkige - informatie van de specialist over diagnose, prognose, resultaten onderzoek, leefregels, risicobeperking en bezoek polikliniek. Patiënten geven aan dat zij niet of onvoldoende geïnformeerd worden over de professionele informatie-overdracht. Soms werd aan de patiënt expliciet gevraagd of hij over een bepaald aspect werd geïnformeerd. Deze vraag vloeide voort uit het verhaal wan de patiënt. Soms kwamen aspecten uit het schema in de loop van het interview helemaal niet aan de orde. Hieruit kan men concluderen dat de patiënt blijkbaar niet expliciet op de hoogte is gesteld van bijvoorbeeld de professionele informatie-overdracht of de mogelijkheid of eventuele noodzaak om na ontslag uit het ziekenhuis wijkverpleegkundige hulp te krijgen. Wat betreft dit laatste is het interessant te vermelden dat twee patiënten aangeven dat zij vermoeden dat zij de hulp van een wijkverpleegkundige moeten accepteren.

De toestemming van de patiënt voor de verwijzing wordt volgens het schema niet expliciet gevraagd.

Tenslotte geeft het schema aan dat patiënten niet worden geïnformeerd over deskundigheden en persoonlijke kwaliteiten van specialisten of de wijze van verzorgen in verschillende ziekenhuizen. Patiënten geven aan dat zij meestal worden verwezen naar het ziekenhuis dat ze al kennen.

Naar aanleiding van het bovenstaande kan een aantal vragen worden geformuleerd die in de volgende hoofdstukken behandeld worden. Op welke wijze dient met rechten van patiënten bij overdracht van zorg te worden omgegaan (hoofdstuk 3)? Welke zijn de opvattingen en ervaringen van patiënten, artsen en verpleegkundigen ten aanzien van het overdrachtsproces (hoofdstuk 4)? Kunnen daaruit voorwaarden voor overdracht van zorg worden gedestilleerd, die maximaal tegemoet komen aan de rechten van de patiënten (hoofdstuk 6)?

\subsection{Indeling van het boek}

Met het voorgaande is in hoofdlijnen de indeling van het boek aangegeven. Het bevat zeven hoofdstukken.

In hoofdstuk 2 wordt een methodologische verantwoording van de gekozen onderzoeksmethoden gegeven.

Hoofdstuk 3 belicht het juridisch kader van dit onderzoek. Onderwerp van beschrijving zijn de bij overdracht van zorg meest relevant geachte rechten van patiënten.

Hoofdstuk 4 gaat in op de opvattingen en ervaringen wan patiënten, artsen en verpleegkundigen ten aanzien van overdracht van zorg met betrekking tot de rechten van patiènten. Na een beschrijving van de onderzoeksopzet volgen de resultaten.

In hoofdstuk 5 wordt het juridisch kader naast de opvattingen en ervaringen van 
patiënten, artsen en verpleegkundigen gelegd en wan commentaar voorzien. Hoofdstuk 6 is gewijd aan het Delphi-onderzoek. Voorwaarden voor overdracht van zorg, gebaseerd op het juridisch kader en de interviews, worden in de vorm van stellingen voorgelegd aan een deskundig panel, om na te gaan in hoeverre consensus kan worden bereikt.

Hoofdstuk 7 is een concluderend hoofdstuk waarin aanbevelingen worden gedaan ten aanzien van de voorwaarden voor overdracht van zorg en kanttekeningen worden geplaatst bij de gehanteerde onderzoeksmethode. 



\section{METHODOLOGISCHE VERANTWOORDING}

\section{$2.1 \quad$ Inleiding}

In dit hoofdstuk wordt een methodologische verantwoording gegeven van de gehanteerde onderzoeksmethoden. Zoals in het eerste hoofdstuk is beschreven bestaat dit onderzoek uit drie delen, een analyse van wet- en regelgeving, jurisprudentie en zelfregulering, interviews met patiënten, artsen en verpleegkundigen en een Delphi-methode (schema 2.1). De volgorde van deze onderzoeksmethoden kan als volgt worden beargumenteerd. Met het bestuderen van de literatuur werd inzicht verkregen in de rechtspositie van de patiënt bij overdracht van zorg. Dit normatief juridisch kader vormde de basis voor de volgende twee fasen van het onderzoek. Met behulp van de interviews werd ernaar gestreefd inzicht te verkrijgen in de wijze waarop patiënten, artsen en verpleegkundigen het overdrachtsproces hadden ervaren. Vervolgens zijn de indikaties die voortkwamen uit de vergelijking tussen het juridisch kader en de interviews, voorgelegd aan een Delphi-panel. Dit onderzoek levert geen bijdrage aan sociaal-wetenschappelijke theorievorming rondom het werschijnsel overdracht van zorg, maar geeft aan in welke mate een panel, bestaande uit vertegenwoordigers van beroepsbeoefenaren in de gezondheìdszorg, instemt met geformuleerde voorwaarden.

\section{$2.2 \quad$ De literatuurstudie}

Om inzicht te krijgen in de heersende opvattingen ten aanzien van rechten van patiènten is in de eerste plaats het geldend recht bestudeerd. Bij de analyse en rapportage van de resultaten heeft toespitsing plaatsgevonden op (toekomstige) wetgeving. De reden hiervoor was dat deze wetgeving beschouwd kan worden als een soort kristallisatie van de rechtsontwikkelingen ten aanzien van de rechten van patiënten en omdat die - in tegenstelling tot jurisprudentie en zelfregulering - beoogt een algemene geldigheid te hebben. Bij de beschrijving van het juridisch kader - toegespitst op de rechtspositie van de patiënt bij overdracht van zorg - wordt dus geen uitvoerig overzicht gegeven van allerlei regelingen. Het normatieve diende als uitgangspositie bij de interviews.

\subsection{De interviews}

Dit onderzoek heeft het karakter van een kwalitatief onderzoek. Smaling (1987, p. 244) omschrijft dit begrip als "een empirische onderzoeksstrategie waarbij de dataverzameling meestal informeel (minder van te voren geregeld) is en waarbij de data-analyse niet kwantificerend is. Hiermee onderscheidt kwalitatief onderzoek zich van journalistiek, kunst, niet-empirisch onderzoek en kwantificerend onderzoek". 


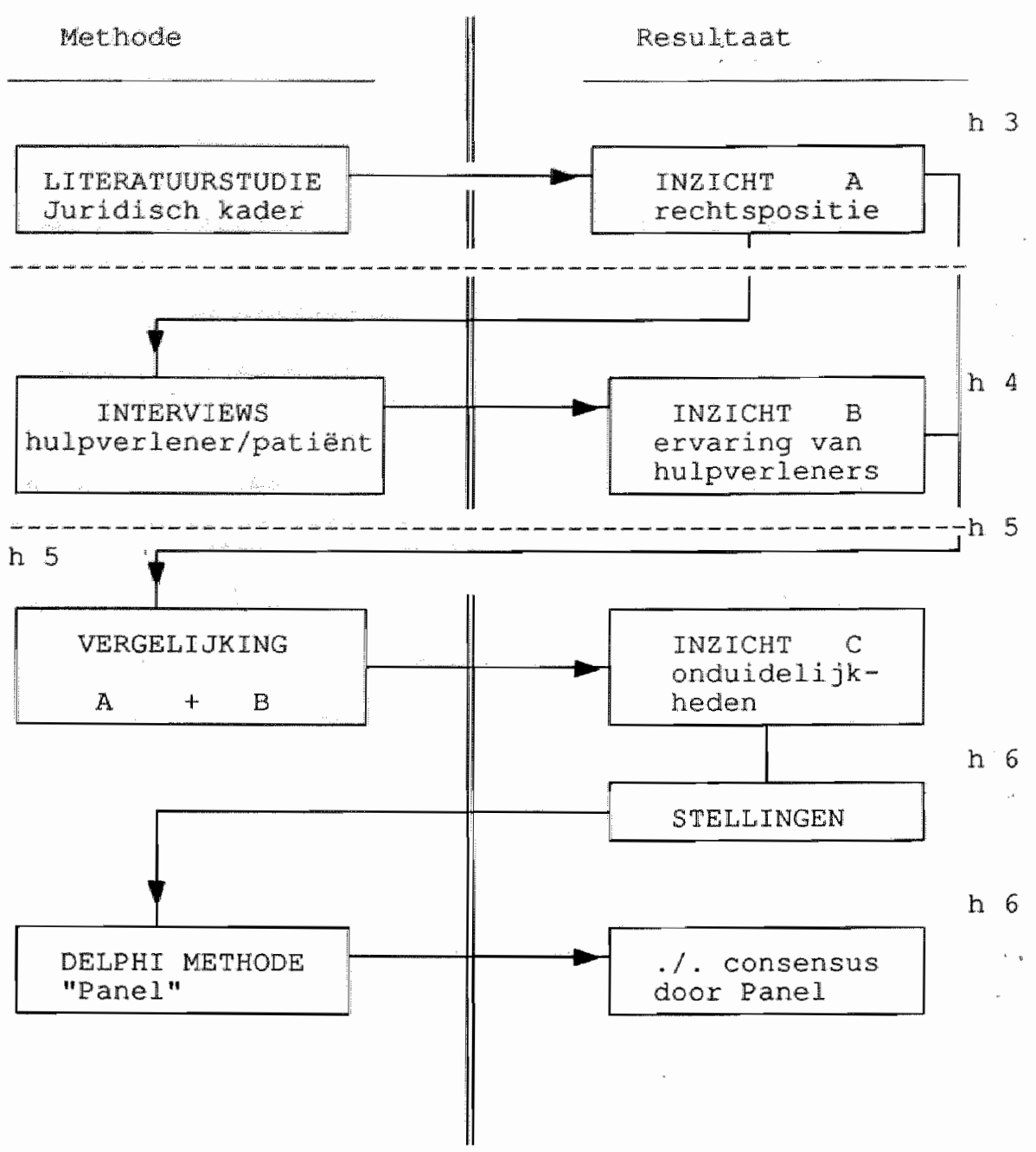

Schema 2.1 Opbouw onderzoeksmethode

Zowel Maso (1988,p. 11) als Wester (1987, p. 43) achten het verschil tussen kwalitatief en kwantitatief onderzoek gelegen in de onderzoekspraktijk zelf. Maso denkt hierbij aan de vraggstelling die gericht dient te zijn op de aard van een sociaal verschijnsel. Kwantitatieve onderzoeksmethoden worden in zijn ogen gebruikt om de mate van optreden van (elementen van) sociale verschijnselen te onderzoeken. Wester legt de nadruk op het verschil in onderzoeksprocedure of de werkwijze. Hij stelt: "In de kwalitatieve methodologie ligt de nadruk op de aansluiting bij het veld van onderzoek, waarbij een open benadering wordt gehanteerd en de vrijheid en de kreativiteit van de onderzoeker woorop staat". 
De opvatting van Leininger $(1985$, p. 5) komt met die van Wester overeen. Zij stelt: "The qualitative type of research refers to the methods and techniques of observing, documenting, analysing and interpreting attributes, patterns, characteristics, and meanings of specific, contextual or gestaltic features of phenomena under study". Het doel hierbij is: "to document and interpret as fully as possible the totally of whatever is being studied in particular contexts from the people's viewpoint or frame of reference".

De overweging om in dit onderzoek voor de kwalitatieve onderzoeksstrategie te kiezen is in de eerste plaats pragmatisch van aard (Smaling 1987, p. 265). De keuze om niet te beginnen met een theoretische beschouwing uitmondend in hypothesen is gebaseerd op de geringe hoeveelheid literatuur over de rechtspositie van de patiënt in relatie tot overdracht van zorg. In zowel medische als verpleegkundige vakliteratuur is veel geschreven over de problematiek rondom de verwijzing naar en het ontslag uit het ziekenhuis, doch het perspectief van de rechtspositie van de patiënt ontbreekt veelal. Bovendien is deze literatuur voor het merendeel normatief van aard.

De tweede overweging is paradigmatisch van aard (Smaling 1987, p. 247); wij waren geïnteresseerd in de aard van het verschijnsel overdracht van zorg en zochten naar een antwoord op de vraag op welke wijze patiënten, artsen en verpleegkundigen het overdrachtsproces interpreteerden. Wij wilden de verhalen van de respondenten zo natuurgetrouw mogelijk weergeven waardoor geen onpersoonlijke informatie zou worden verkregen, maar informatie die recht doet aan het subject, zogenaamde objectieve informatie (Reuling 1986, p. 78).

De kwalitatieve onderzoeksmethode leek gezien onze onderzoeksvraag de meest geëigende. Hoewel de term kwalitatief onderzoek in wezen staat voor een aantal uiteenlopende benaderingen kunnen zonder veel bezwaar de volgende typeringen worden genoemd (Nooy 1977; Wester 1978):

- er dient sprake te zijn van role taking, het vermogen jezelf te verplaatsen in de positie van een individu of groep. Voor de onderzoeker betekent dit dat hij de gedragssituatie definieert volgens de betekenissen die de onderzochten zelf aan die situatie toeschrijwen. Kortom, hij moet proberen in hun huid te kruipen.

- direct examination of the emperical world, ook wel "going native" genoend. Niet eerst begrippen construeren, operationaliseren en vervolgens meten, maar zoveel mogelijk direct contact zoeken met deze werkelijkheid, de leefwereld van betrokkenen. Theorieën en begrippen moeten via het onderzoek van de werkelijkheid ontwikkeld worden.

- first hand involvement with the social world. De onderzoeksprocedure moet zo open mogelijk zijn, moet gericht zijn op direct contact met de werkelijkheid. De voorkeur wordt gegeven voor participerende observatie en case-study. Op deze onderzoeksmethoden wordt in hoofdstuk 4 nader ingegaan. Vervolgens moet deze werkelijkheid in begrippen worden geobjectiveerd.

De pragmatische en paradigmatische overwegingen hebben ertoe geleid dat interviews zijn gehouden met patiënten, artsen en verpleegkundigen. De vraag waarom voor deze techniek is gekozen wordt in hoofdstuk 4 beantwoord. Vervolgens is 
een-analyse-in-eerste-instantie toegepast. Dit betekent dat alle kennis die is verworven bij het formuleren van de probleemstelling en de onderzoeksopzet, evenals de gedachten tijdens het verzamelen, in deze fase tussen haakjes worden gezet. Hierbij kunnen de volgende stappen worden onderscheiden (Maso 1987, p. 114):

1. De registratie en verslagen van de verschijnselen die in de onderzoekssituatie zijn aangetroffen worden versehillende malen gelezen zonder poging tot verklaring.

2. Het beeld dat in de vorige stap is verkregen wordt verdiept en uitgebreid door het accent te leggen op de details van de verschijnselen.

3. De aangetroffen verschijnselen worden zo mogelijk verklaard door ze met elkaar in verband te brengen.

4. De al dan niet met elkaar in verband gebrachte verschijnselen worden onderzocht om te zien of ze ến of meer onderwerpen of thema's vertegenwoordigen, die alleen of te zamen de betekenisvolle eenheid van die verschijnselen vormen.

5. De verzamelde gegevens worden nog eens nagelopen om voor zover nodig de preciese betekenissen van die verschijnselen vast te stellen.

6. De gegevens worden nogmaals bekeken om te zien of ze inzicht kunnen verschaffen in een mogelijk antwoord op de voorlopige probleemstelling of in die probleemstelling zelf.

In paragraaf 4.2.3 wordt op deze analyse nader ingegaan. Met de analyse-in-eersteinstantie hebben wij een bevredigend - zij het niet volledig - inzicht verkregen in opvattingen en ervaringen van patiënten en hulpverleners ten aanzien van het overdrachtsproces.

De koppeling van de gegevens uit de analyse-in-eerste-instantie met bestaande theorieën en meningen, ook wel de-analyse-in-tweede-instantie genoemd (Maso 1987 , p. 115), is achterwege gelaten. Dit had te maken met het feit dat wij gezien de vraagstelling - niet geinteresseerd waren in een theoretische verklaring voor de verschillende verschijnselen. Het was niet de bedoeling om de inzichten die we verkregen hadden met behulp van de interviews, te laten uitmonden in een sociaal wetenschappelijke theorie.

\section{$2.4 \quad$ Delphi-methode}

In plaats van een analyse-in-tweede-instantie hebben wij de Delphi-methode toegepast. De stellingen zijn gebaseerd op de indicaties die bij vergelijking tussen het juridisch kader en de interviews naar voren kwamen. Ze zijn dus niet primair aan het juridisch kader ontleend.

De keuze voor de Delphi-methode berust op een aantal overwegingen. Wij wilden inzicht krijgen in de opvattingen van enkele representatieve vertegenwoordigers van de verschillende beroepsgroepen in de gezondheidszorg, ten aanzien van de voorwaarden voor overdracht van zorg. Het panel is zorgvuldig en weloverwogen samengesteld. Kwantitatieve vertegenwoordiging is niet de bedoeling. Het gaat steeds om het vermogen te generaliseren en om het geheel van belangen en be- 
langhebbenden dat vertegenwoordigd is. Panelleden dienen derhalve acceptabel te zijn, zowel op basis van hun deskundigheid als op basis van hun integriteit en betrokkenheid bij de doelgroep(en) (Donabedian 1982, p. 175-180).

Het terugkoppelen van de resultaten en de herhaalde presentatie van de stellingen komt enerzijds de validiteit en de betrouwbaarheid van de verkregen antwoorden ten goede, anderzijds verhoogt dit de acceptatie van de onderzoeksresultaten. Een degelijk effect is van belang voor het in praktijk brengen van deze resultaten.

Op de voor- en nadelen van de Delphi-methode wordt verder ingegaan in hoofdstuk 6 . 



\title{
3. RECHTEN VAN PATIENTEN:
}

\author{
JURIDISCH KADER
}

\section{$3.1 \quad$ Inleiding}

In dit hoofdstuk zal, na een korte algemene schets van de rechten van de patiënt die grotendeels gebaseerd is op het Handboek Gezondheidsrecht (Leenen, 1988) nader worden ingegaan op de rechten die in het kader van overdracht van zorg van belang zijn. Hierbij wordt met name uitgegaan van (toekomstige) wettelijke regelingen zoals het Voorontwerp geneeskundige behandelingsovereenkomst, waarin de ontwikkelingen ten aanzien van de rechten van de patiënt zijn gecondenseerd en de Wet persoonsregistraties.

\section{2}

\section{Algemene schets}

Internationale rechtsontwikkeling na de Tweede Wereldoorlog heeft een stevig fundament gelegd voor vrijheids- en persoonlijkheidsrechten, die inmiddels ook onder onze grondrechten een vaste plaats hebben verworven. Het gaat dan met name om artikelen 10 en 11 , zoals die sinds 1983 in de Grondwet staan en in 1988 in werking zijn getreden. Zij strekken tot bescherming van ieders privacy en persoonlijke integriteit. Het noodzakelijk complement daarvan ligt besloten in de onder de zgn. sociale grondrechten vervatte plicht van de overheid om te zorgen yoor een goede gezondheidszorg (art. 22 Grondwet). Dit recht op gezondheidszorg geeft aan individuele rechten de vereiste maatschappelijke dimensie.

De groeiende belangstelling voor de verstrekking van de rechtspositie van de patiënten is volgens Leenen (1988, p. 151) tot ontwikkeling gekomen door:

- een WHO-seminar waarin door Prof.Dr. A. Querido en Prof. G. Kraus een ontwerp-declaratie van de rechten van de patiènt werd opgesteld (1953);

- de ontwikkeling van het gezondheidsrecht in de jaren zestig;

- het jaar van de rechten van de mens (1968);

- de introductie van het vak gezondheidsrecht aan enkele universiteiten;

- de oratie van J. Rang in 1973 over patiëntenrecht;

- het toenemend aantal publikaties over de rechten van de patiënt, komende uit verschillende hoeken;

- de opkomst van groepen voor de belangenbehartiging van patiềnten;

- de toenemende belangstelling in de media voor de rechten van de patiënt.

In 1977 vroeg de regering advies aan de aan de toenmalige Centrale Raad voor de Volksgezondheid inzake de positie van de patiënt. De Raad stelde een Commissie 
Rechten van de patiënt in onder voorzitterschap van Leenen. Deze Commissie produceerde tussen 1980 en 1982 vijf deeladviezen, welke achtereenvolgens behandelen:

- de juridische relatie tussen patiënt en arts, het recht van de patiënt op informathe en het toestemmingsvereiste;

- de bescherming van de privacy van de patiênt;

- medische experimenten met mensen;

- bemiddeling bij klachten van patiënten;

- kernbepalingen voor de regeling van de relatie tussen patiênt en arts.

Het regeringsstandpunt ten aanzien van deze adviezen werd achtereenvolgens werwoord in de Nota Patiëntenbeleid van 1981, de Voortgangsnota Patiëntenbeleid (1983) en de Tweede Nota Voortgangsnota Patiëntenbeleid (1988). De Nota Patièntenbeleid kenmerkt zich door een verkennende, stapsgewijze benadering, waarbij het accent ligt op een inventarisatie van de rechtspositie van de patiënt in het gezondheidszorgsysteem. Ten aanzien van het patiëntenbeleid wordt een onderverdeling gemaakt tussen voorlichting, participatie, patiëntenorganisaties en patiêntenrecht. De Voortgangsnota uit 1983 is veel gedetailleerder en concreter wat betreft de rechtspositie van de patiënt. Wettelijke regelingen inzake rechten van de patiënt worden in het vooruitzicht gesteld. In de Tweede Voortgangsnota Patiẻntenbeleid wordt gesteld dat de huidige rechtspositie van de patiënt, zoals vastgelegd in wettelijke regelingen, wel op onderdelen, maar niet in het algemeen voldoende inzichtelijk en in concrete situaties toepasbaar en afdwingbaar is. Het beleid dient derhalve gericht te zijn op het creëren van een rechtspositie die voldoet aan de eisen van overzichtelijkheid, bruikbaarheid en afdwingbaarheid.

De bescherming van de rechtspositie van de patiënt komt in verschillende (op handen zijnde) regelingen tot uiting. $\mathrm{Ze}$ zijn verschillend van aard en rechtskracht. Rechten van patiënten zullen in civielrechtelijke wetgeving geregeld gaan worden in onder andere de behandelingsovereenkomst. Administratiefrechtelijke wettelijke bepalingen ten aanzien van de rechten van patiënten treft men onder andere aan in de Wet persoonsregistraties, het Wetsvoorstel bijzondere opneming in psychiatrische ziekenhuizen en het Wetsvoorstel democratisch functioneren van zorginstellingen.

De rechtspraak heeft tot nu toe ten aanzien van de rechtspositie van de patiënt een belangrijke rol gespeeld. Vooral in de jurisprudentie van de civiele rechter en medisch tuchtrechter, maar ook van de administratieve rechter en de strafrechter zijn de rechten van patiënten, zoals het recht op informatie, het toestemmingsvereiste en het inzagerecht aan de orde geweest. Hoe belangrijk dit uit oogpunt van rechtsontwikkeling ook is geweest, uit het oogpunt van rechtszekerheid is de rechtspraak niet optimaal. $\mathrm{Zij}$ is casuistisch en fragmentarisch. $\mathrm{Zij}$ loopt bovendien vaak vooruit op aangekondigde wetgeving. Op deze wijze lopen de toetsing van incidentele gevallen en regelgeving door elkaar: de uitspaak van de rechter heeft weliswaar een normerende werking, maar zij is niet algemeen bindend.

Het erkenningensysteem is, als het gaat om de rechtsbescherming van de patiënt, een vorm van zogenaamde indirecte regelgeving. Mogelijkheden voor een adequate 
rechtshandhaving zijn met dit systeem beperkt, maar het biedt wel een ondersteunend kader voor de rechtspositie van de patiënt (Leenen 1986, p. 87; Roscam Abbing 1985, p. 2).

Tenslotte kunnen rechten van patiënten door zelfregulering geregeld worden. De wetgever geeft het kader aan, schept garanties en houdt toezicht, maar laat de uitvoering over aan maatschappelijke organisaties. Een nadeel van zelfregulering is dat derden vaak formeel weinig of geen invloed kumnen uitoefenen op de regelgeving door de desbetreffende privaatrechtelijke organisaties. Daardoor ontstaat macht van een bepaalde groep over andere groepen. Bovendien kan het schorten aan openbaarheid of verbindendheid en is het risico van onvoldoende uniformiteit aanwezig. Kenmerkend voor zelfregulering is dat de patiënt daar niet rechtstreeks rechten aan kan ontlenen. Een voordeel van zelfregulering is echter dat betrokkenen op flexibele en op de situatie toegesneden wijze een nadere uitwerking kunnen geven aan bij wet vastgestelde hoofdlijnen.

In dit onderzoek vormen (toekomstige) wettelijke regelingen het juridische kader, enerzijds omdat zij kunnen worden beschouwd als condensatie van de ontwikkelingen ten aanzien van de rechten van patiënten, anderzijds omdat zij de meeste rechtskracht hebben. Centraal staan het Voorontwerp geneeskundige behandelingsovereenkomst en de Wet op de persoonsregistraties.

\subsection{Relevante rechten van patiënten nader bezien}

\subsubsection{Inleiding}

In het nu volgende wordt nader ingegaan op welke wijze de in paragraaf 1.5 genoemde rechten in het geding zijn bij overdracht van zorg. Achtereenvolgens worden de volgende rechten belicht:" het recht op informatie, het toestemmingsvereiste, het recht op vrije keuze, het recht op informationele privacy en het recht op inzage.

\subsubsection{Recht op informatie}

Informatieverstrekking aan de patiënt - door Van Wijmen (1988) in het kader van een beschouwing over patiëntenvoorlichting de scharnier genoemd, waar alle andere rechten van patienten om draaien - is bij overdracht van zorg van belang om de patiënt bij het proces te betrekken en hem tevens de mogelijkheid te geven zijn andere rechten tot gelding te brengen (bijvoorbeeld om zijn toestemming te geven voor de verwijzing, de professionele informatie-overdracht en het eventueel inschakelen van een wijkverpleegkundige), maar ook om hem inzicht te geven in zijn keuzemogelijkheden. In deze paragraaf zal nader worden ingegaan op de vraag wat het recht op informatie in relatie tot het overdrachtsproces betekent en hoe een en ander wettelijk is/wordt geregeld. Hierbij wordt uitgegaan van de volgende ordening: wie moet de informatie verstrekken, waarover gaat de informatie, op welke wijze wordt informatie verstrekt en wanneer wordt wel en wanneer wordt geen informatie verstrekt? 
Artsen en verpleegkundigen die de patiènt respectievelijk behandelen en verzorgen hebben in principe een eigen plicht tot informatie van de patiënt. Primair is overdracht van zorg een medische aangelegenheid; de huisarts kan niet verder behandelen of heeft behoefte aan nadere diagnostische gegevens. De huisarts is daarom de eersit aangewezene om de patiënt te informeren. Als een huisarts de patiènt heeft verwezen voor onderzoek door de specialist, die na bericht aan de huisarts geen verdere activiteiten onderneemt, dan blijft de huisarts degene die de patie̊nt op de hoogte dient te stellen (Leenen 1988, p. 169).

Indien de patiént vór opname in het ziekenhuis wijkverpleegkundige zorg ontvangt dient de wijkverpleegkundige de patiënt te informeren over verpleegkundige aangelegenheden. Bij ontslag uit het ziekenhuis dienen de specialist en de ziekenhuisverpleegkundige de patiënt op hun beurt te informeren. Ook hier zet de specialist de eerste stap gevolgd door de ziekenhuisverpleegkundige die zorgt voor informatie betreffende haar vakgebied.

Het uitgangspunt dat de voor de zorg verantwoordelijke hulpverlener de patiënt informeert krijgt gestalte in de toekomstige wetgeving (Voorontwerp geneeskundige behandelingsovereenkomst art. $1653 \mathrm{~b}$ lid 1 en 2 en art. 1653c).

\section{* Waarover gaat de informatie?}

De informatie bij overdracht van zorg dient de patiënt:

- op de hoogte te brengen van problemen rond zijn gezondheidstoestand;

- in staat te stellen te beslissen;

- inzicht te geven in wat zijn eigen aandeel kan zijn in het overdrachtsproces. In paragraaf 2.2 introduceerden wij hiervoor reeds de begrippen "informed referral" en "informed discharge".

De inhoud van de informatie wordt bepaald door degene die de informatie verstrekt. Zo heeft de informatie van een verpleegkundige betrekking op de verpleging en de verzorging van een patiënt, terwijl de informatie van een arts betrekking heeft op de behandeling.

De huisarts dient de patiënt bij verwijzing naar het ziekenhuis te informeren omtrent zijn ziekte en de reden van de verwijzing. Bij een verwijzing kan onzekerheid bestaan omtrent het gezondheidsprobleem van de patiënt en over hetgeen hem in het ziekenhuis te wachten staat. Leenen stelt hierover dat "er marges van onzekerheid kunnen zijn over een aantal punten, waardoor eventuele schattingen in redelijkheid op grond van de professionele standaard moeten kunnen worden verantwoord. Ongegronde vermoedens mogen niet als zeker worden gepresenteerd" (Leenen 1988, p. 166). Bovendien stelt Leenen (1988, p. 167) dat de arts bepaalde zaken als bekend mag veronderstellen. Hij denkt hier onder andere aan het feit dat bij een ziekenhuisopname veelal bloed wordt afgenomen en dat urine wordt onderzocht. Gezien de "Aids-discussie" vandaag de dag kan de vraag worden gesteld of de huisarts de patiënt niet juist moet informeren over wat 
wel of niet mag en/of moet bij bloedonderzoek. Tenslotte dient de huisarts net zoals de wijkverpleegkundige de patiènt te informeren omtrent de professionele informatie-overdracht aan de specialist (Leenen 1988, p. 202).

De bij de zorg betrokken wijkverpleegkundige dient de patiënt te informeren over het feit dat informatie wordt verstrekt aan de ziekenlhuisverpleegkundige, waarbij tevens wordt verteld waarom deze informatie wordt verstrekt. Eventueel kan zij de patiënt ook informeren over de wijze van verzorgen in het ziekenhuis, zoals het eventueel taak- of patiëntgericht verplegen. Bij ontslag uit het ziekenhuis dient de ziekenhuisverpleegkundige de patiënt te informeren over de mogelijkheden en eventuele noodzaak van wijkverpleegkundige hulp, alsmede over het feit dat; bij het inschakelen van een wijkverpleegkundige, informatie-overdracht plaats vindt.

De specialist dient de patiënt voor het ontslag uit het ziekenhuis te informeren over diagnose, prognose, resultaten onderzoek, leefregels, risicobeperking en bezoek polikliniek, alsmede over de professionele informatie-overdracht aan de huisarts.

Bovenstaande uitgangspunten krijgen gestalte in het Voorontwerp geneeskundige behandelingsovereenkomst. In artikel $1653 \mathrm{~b}$ lid 1 wordt aangegeven waar de informatie van artsen betrekking op dient te hebben: aard en doel van het onderzoek of de behandeling die de hulpverlener mogelijk acht, over de te verwachten gevolgen en de risico's daarvan voor de gezondheid van de patiënt, over andere methoden van onderzoek of behandeling die in aanmerking komen, alsmede over de staat en de vooruitzichten met betrekking tot diens gezondheid voor wat betreft het terrein van onderzoek of behandeling.

Het (toekomstige) wettelijk vereiste dat de patiënt geïnformeerd dient te worden over de informatie-overdracht aan derden kan worden afgeleid uit de Wet persoonsregistraties (art. 12 lid 1) en van het Voorontwerp geneeskundige behandelingsovereenkomst (art. 1653l, lid 1). Volgens Leenen (1988, p. 201), die zich baseert op artikel 16531 lid 2 Voorontwerp geneeskundige behandelingsovereenkomst, kan de toestemming van de patiënt verondersteld worden bij de gegevensuitwisseling tussen de bij de zorg betrokken hulpverleners, behoudens indien het gaat om een uitdrukkelijk toevertrouwd probleem. Deze veronderstelde toestemming sluit echter niet uit dat de patiënt wel geïnformeerd dient te worden omtrent de gegevensuitwisseling (Leenen 1988, p. 202).

Leenen (1988, p. 166) geeft eveneens aan waar de informatie van de arts uit dient te bestaan. Deze punten krijgen voor het merendeel gestalte in bovengenoemde wetgeving. Extra zijn de informatie omtrent ervaringen van een arts met therapeutische mogelijkheden; de rol bij de behandeling van de bij de hulpverlening betrokken hulpverleners; de bereikbaarheid van de hulpverlening en vervangingsregelingen; praktische regelingen als bezoektijden en regelingen op de verpleegafdeling. Leenen geeft aan dat deze lijst nog aangevuld kan worden. Hij stelt daarbij dat de algemene norm, die bij de informatie aan de patiënt het beste kan worden aangehouden, het verstrekken van inlichtingen is over feiten en mogelijkheden die 
en redelijk mens in de gegeven omstandigheden verwacht mag worden te overwegen alyorens hij een beslissing neemt, die hij behoeft voor zijn verdere levensgedrag (Leenen 1988 , p. 167).

Informatie over laatstgenoemde aspecten, zoals de bereikbaarheid van hulpverleners en ervaringen met therapeutische mogelijkheden, kunnen ook in het kader van de verwijzing naar het ziekenhuis van belang zijn. De huisarts kan de patiënt hierover informeren. De specialist en/of de ziekenhuiswerpleegkundige zijn de aangewezen personen om de patiënt te informeren over de bezoektijden en regelingen op de verpleegafdeling. $\mathrm{Ze}$ zijn hierover beter genformeerd en deze informatie is bovendien niet noodzakelijk woor de patiënt om in te kunnen stemmen met de verwijzing.

\section{* Wanneer wel en wanneer geen informatieverstrekking?}

Informatie verstrekken hoort tot de professionele standaard. Het recht op informatie is erop gericht een goede besluitvorming door de patiënt mogelijk te maken. Informatie kan bij overdracht van zorg achterwege worden gelaten in geval van een $\mathrm{zgn}$. therapeutische exceptie: de arts acht het beter om in dit geval de patiënt niet te informeren omdat dit de patiënt nadeel kan toebrengen. Dit beginsel is te vinden in het Voorontwerp geneeskundige behandelingsovereenkomst (art. 1653b lid 2).

Formuleringen als "nadeel ondervinden" en "schadelijk zijn" laten veel ruimte. Gezondheidsjuristen, onder wie Leenen (1988, p. 164) waarschuwen tegen het te soepel hanteren van de therapeutische exceptie, omdat dit het recht op informatie zou uithollen.

Informatie van de patiënt dient volgens het Voorontwerp geneeskundige behandelingsovereenkomst evenmin plaats te vinden indien deze te kennen heeft gegeven geen inlichtingen te willen ontvangen, behoudens voorzover de arts gelet op de aard van de verrichtingen, de informatie noodzakelijkerwijs aan de patiënt dient te verstrekken (art. 1653c). Bij overdracht van zorg kan, als sprake is van een therapeutische exceptie, de specialist, wel worden geïnformeerd, ook al is de patient zelf (nog) niet op de hoogte van de informatie.

\section{* De wijze van informatieverstrekking}

Informatie kan mondeling en schriftelijk worden verstrekt. In principe dient de patiënt mondeling deugdelijk te worden geïnformeerd. Schriftelijke informatie dient ter ondersteuning van de mondelinge informatie, bijvoorbeeld bij moeilijke ingrepen. Bij overdracht van zorg kan de patiënt de arts en de verpleegkundige verzoeken om bepaalde mondeling verstrekte informatie op papier te zetten. Dit uitgangspunt is te vinden in het Voorontwerp geneeskundige behandelingsovereenkomst (art. 1653b).

De informatieplicht geldt ten aanzien van de patiënt en niet ten aanzien van de familie. Indien de patiënt echter niet in staat kan worden geacht de informatie terstond te verwerken kan ook een ander, bijvoorbeeld een familielid, worden ingelicht (art. 1653b lid 2). In de jurisprudentie is de wijze van informatie 
verstrekken enigszins verder genormeerd, overigens op geleide van de literatuur. Zo dient de arts zich ervan te vergewissen dat de patiënten de informatie in volle omvang heeft begrepen. Voor het geven van informatie moet de tijd worden genomen. De informatie moet ook in begrijpelijke vorm worden gegeven.

\subsubsection{Het toestemmingsvereiste}

Het toestemmingvereiste geeft de patiènt de mogelijkheid on invloed uit te oefenen op de te volgen procedure, waarmee hij actief bij het overdrachtsproces wordt betrokken.

In deze paragraaf wordt ingegaan op de vraag waarvoor bij overdracht van zorg toestemming vereist is en op welke wijze de toestemming van de patiënt moet worden verkregen.

\section{* Waarvoor is toestemming vereist?}

Voor de verwijzing naar het ziekenhuis dient de patiënt expliciet toestemming te geven. Immers, bij overdracht van zorg is er sprake van een overdracht van verantwoordelijkheid voor de zorg van een patiënt. Aangezien hulpverleners die werkzaam zijn in een ander echelon bij de hulpverlening worden betrokken kan niet worden uitgegaan van veronderstelde toestemming. Leenen $(1988$, p. 173) stelt over veronderstelde toestemming het volgende: "In het algeneen doet de arts er goed aan de toestemming niet te snel te veronderstellen, mede omdat de bewijslast voor de verkregen toestemming op de arts rust. Loutere passiviteit van de patiënt, het toelaten van de behandeling, impliceert op zichzelf nog geen toestemming".

Toestemming is niet vereist indien het belang van de patiënt vereist dat tot de verrichting onverwijld wordt overgegaan ( $1653 \mathrm{~d}$ lid $4 \mathrm{a}$ ). Hiervan is bij overdracht van zorg sprake bij bijvoorbeeld een acute verwijzing van een comateuze patiënt naar het ziekenhuis.

De toestemming van de patiënt is vereist voor informatie-overdracht aan derden (Voorontwerp geneeskundige behandelingsovereenkomst art. 16531 lid 1 en Wet persoonsregistraties art. 11 lid 1). In paragraaf 3.3.2 is aangegeven dat van veronderstelde toestemming kan worden uitgegaan bij de informatie-overdracht tussen bij de behandeling betrokken personen. Informatie omtrent deze overdracht stelt de patiënt in staat hiertegen bezwaar te maken. Hierdoor komt de veronderstelde toestemming te vervallen (Leenen 1988, p. 202).

Voor ontslag uit het ziekenhuis is de toestemming van de patiënt geen vereiste aangezien het verblijf van een patiënt in het ziekenhuis gebaseerd is op een medische indicatie. Als de specialist tot de conclusie komt dat een patient ontslagen kan worden dan is dit zijn beslissing, waarvoor de toestemming van de patiënt niet nodig is. Een patiënt kan dus eventueel tegen zijn wil uit het ziekenhuis worden ontslagen, al kan deze situatie worden voorkomen door goed overleg tussen patiënt en specialist.

Aangezien de ziekenhuisverpleegkundigen nauw bij de zorg van de patiënt zijn betrokken, is overleg met hen over ontslag gewenst. Ook kan de specialist de mening van de huisarts betrekken bij zijn beslissing over het ontslag van een 
patiënt. In de wetgeving wordt niet wastgelegd dat de specialist met de ziekenhuisverpleegkundigen en de huisarts dient te overleggen over het ontslag van een patiènt.

\section{* Op welke wijze dient de toestemming te worden verkregen?}

De patiènt moet in staat worden gesteld om in vrijheid zijn toestemming te geven. In het ideale geval krijgt hij de kans om over de eventuele mogelijkheden na te denken, alvorens een beslissing te moeten nemen. De toestemming van de patiënt dient te worden verkregen door ernaar te vragen. Slechts in bepaalde gevallen kan worden uitgegaan van weronderstelde toestemming. In de vorige paragraaf werd op deze uitzonderingen ingegaan. Vervolgens kan de toestemming worden vastgelegd in het dossier of de verwijsbrief. Het vastleggen van de toestemming voor de verwijzing wordt niet wettelijk voorgeschreven. Ook wordt niet bepaald dat de specialist schriftelijk dient vast te leggen, dat hij de patiënt tegen diens wil uit het ziekenhuis ontslaat.

Volgens de Wet persoonsregistraties kan de toestemming van de geregistreerde voor de verstrekking van gegevens uit een persoonsregistratie slechts schriftelijk worden gegeven (art. 12 lid 1) en worden ingetrokken (art. 12 lid 3). In de vorige paragraaf is beschreven dat bij professionele informatie-overdracht van veronderstelde toestemming kan worden uitgegaan. Hierdoor komt het vastleggen van de toestemming komt voor de gegevens-overdracht te vervallen.

\subsubsection{Recht op vrije keuze}

Het recht op vrije keuze is, in tegenstelling tot de hiervoor beschreven rechten niet alleen een individueel maar ook een sociaal grondrecht. Dit laatste betekent dat de overheid het recht op vrije keuze verwezenlijkt voorzover dit mogelijk is, gegeven onder andere de financieel-economische mogelijkheden. Bovendien heeft dit recht eerst onder bepaalde omstandigheden een afdwingbaar karakter (Leenen 1978).

De patiënt heeft bij verwijzing het recht om de specialist of het ziekenhuis te kiezen. Voor ziekenfondsverzekerden is deze keuze echter beperkt tot een hulpverlener of instelling binnen hun woonplaats of in de naaste omgeving (art. 9 ZFW en art. 10 AWBZ). Indien de aard van het ziektegeval dit noodzakelijk maakt, kan een verzekerde overigens wel toestemming worden verleend de noodzakelijke hulp elders in te roepen, mits het betreft een wettelijk geregelde aanspraak (art. 9 lid 4 ZFW en art 10 lid $4 \mathrm{AWBZ}$ ). Daaronder vallen niet alleen gevallen waarin door een tijdelijk c.q. structureel tekort aan gebruikelijke voorzieningen een beroep op voorzieningen buiten de woonplaats of naaste omgeving nodig is, maar ook situaties waarin de voor de specifieke aard van het ziektegeval van verzekerde benodigde behandelingsvorm (zoals superspecialismen) niet in het werkgebied van het ziekenfonds voorhanden is.

Tegenover deze keuzebeperking staat dat geneeskundige verzorging kan worden ingeroepen zonder financiële belemmeringen (Leenen 1986, p. 159). De keuzevrijheid voor particulier verzekerden wordt in het algemeen niet ingeperkt.

Bij verwijzing kan de patiënt in eerste instantie, binnen de hierboven beschreven beperkingen, kiezen voor een bepaalde specialist. Hiervoor dient hij door de 
huisarts deugdelijk te worden geïnformeerd over deskundigheden en persoonlijke kwaliteiten van specialisten en instellingen. De keuze voor een bepaalde specialist impliceert een verwijzing naar een bepaald ziekenhuis, de eventuele opname op een bepaalde verpleegafdeling en de verzorging van de daar werkzame verpleegkundigen.

Bij ontslag uit het ziekenhuis is de keuze van de patiënt doorgaans niet aan de orde: hij wordt weer aan de zorg van zijn huisarts overgedragen. De patiènt heeft ook geen mogelijkheid om voor wijkverpleegkundige zorg te kiezen. Hij komt hiervoor pas in aanmerking als hij aan bepaalde criteria voldoet. Indien de patiènt voldoet aan deze criteria zou hij in principe een keuze moeten kunnen maken uit verschillende wijkverpleegkundigen. De keuze voor een bepaalde wijkverpleegkundige is echter veelal beperkt tot de verpleegkundigen die werkzaam zijn in een bepaalde wijk en/of samenwerken met de betreffende huisarts.

Het recht van de patiënt op vrije keuze van een hulpverlener vindt als zodanig geen neerslag in wet- en regelgeving.

\subsubsection{Het recht op informationele privacy}

De drie belangrijkste aspecten van het recht op privacy zijn de inbreuk op de private sfeer die medische behandeling noodzakelijkerwijze met zich meebrengt, de ruimtelijke privacy van mensen die worden onderzocht in instituten en verblijven en de informationele privacy die de bescherming van persoonlijke gegevens betreft (Leenen 1988, p. 219). Bij overdracht van zorg ligt het accent van de privacybescherming' op het laatste.

Bij deze informationele privacy moeten vier algemene beginselen worden aangehouden (Leenen 1988, p. 222):

1. De patiënt heeft recht op zijn geheim en de beroepsbeoefenaar heeft de plicht om dat geheim te bewaren.

2. De hulpverlener dient gegevens doelgericht te verzamelen en vast te leggen.

3. Het doel van de registratie moet aanvaardbaar zijn en duidelijk zijn omschreven.

4. De gegevens dienen niet voor een ander doel te worden gebruikt dan waarvoor ze zijn verzameld.

\section{* Het recht op geheim}

Ten aanzien van het eerste beginsel kan in het kader van de overdracht van zorg worden geconcludeerd dat de patiënt - bij het gebruik van verwijs- of ontslagbrief respectievelijk overdrachtformulier door de beroepsbeoefenaar - het recht heeft op geheim en dat de beroepsbeoefenaar de plicht heeft om dat geheim te bewaren. In dat verband is in de Wet persoonsregistraties in art. 11 lid 3 een bepaling opgeno-

a Het recht op geheim en en recht op privacy worden in de literatuur apart behandeld (Leenen 1988), omdat het recht op geheim niet alleen een aspect is van privacy, maar ook van de beroepsplichten van de arts en andere hulpverleners, waarbij aspecten als zwijgplicht en verschoningsrecht een rol spelen. 
men dat de verstrekking van gegevens aan derden achterwege blijft voor zover uit hoofde wan ambt, beroep of wettelijk voorschrift geheimhouding geboden is. Wat betekent dit in concreto? Artsen en verpleegkundigen dienen in het kader van overdracht van zorg gegevens uit te wisselen, waardoor de continuiteit van zorg gewaarborgd wordt en de zorg op een verantwoorde wijze kan worden overgenomen. $\mathrm{Zij}$ dienen deze gegevens alleen in verwijs- en ontslagbrieven c.q overdrachtformulieren op te nemen indien zij de overtuiging hebben dat het geheim van de patiênt voldoende is beschermd. Bij overdracht van zorg kunnen de belangen van de hulpverlener om bepaalde gegevens over te dragen - bijvoorbeeld om te continuîtteit van zorg te garanderen - nooit zo groot zijn dat hierdoor het recht van de patiënt op geheim moet wijken. Alleen de patiënt zelf heeft die mogelijkheid als niet in een wettelijke regeling anders is voorzien (Leenen 1988, p. 223).

\section{* Doelgericht verzamelen en vastleggen}

Volgens het tweede beginsel - de hulpverlener dient gegevens doelgericht te verzamelen en vast te leggen - dienen de huisarts en wijkverpleegkundige bij de verwijzing van de patiënt naar het ziekenhuis voor hun verwijsbrief respectievelijk overdrachtformulier gegevens doelgericht te verzamelen en deze doelgericht vast te leggen. Dit betekent dat brieven en formulieren slechts mogen worden opgesteld indien dit noodzakelijk is voor de continuïteit van zorg en tevens de verantwoordelijkheid op verantwoorde wijze kan worden overgedragen. Wettelijk ligt dit beginsel vast in de Wet persoonsregistraties artikel 18 lid 1 en 2 . Bovendien wordt in artikel $1653 \mathrm{i}$ lid 1 van het Voorontwerp geneeskundige behandelingsovereenkomst bepaald dat de hulpverlener aantekening dient te houden van de gegevens omtrent de gezondheid van de patiënt en de te diens aanzien uitgevoerde verrichtingen, voorzover dit voor een goede hulpverlening noodzakelijk is. Alleen in de Gedragsregels voor artsen wordt aangegeven welke gegevens moeten worden vastgelegd bij overdracht van zorg: antwoorden op concrete, gerichte en relevante vragen die berusten op verricht onderzoek en voorlopig eigen oordeel toegespitst op het indiwiduele geval en beperkt tot het terrein dat door de vraagstelling wordt aangegeven (regel 78). Copieën, rapporten en brieven die voor een ander doel werden opgesteld komen in het algemeen niet voor informatie-overdracht in aanmerking (regel 79).

\section{* Doel registratie aanvaardbaar en duidelijk omschreven}

Volgens het derde beginsel dient bij overdracht van zorg het doel van verwijs- en ontslagbrieven c.q. overdrachtformulieren aanvaardbaar te zijn en duidelijk te zijn omschreven.

\section{* Doelgebonden gebruik gegevens}

Volgens het vierde uitgangspunt dienen gegevens niet te worden gebruikt voor een ander doel dan waarvoor ze zijn verzameld. Wettelijk ligt dit beginsel vast in de Wet persoonsregistraties (art. 6 lid 1). Gegevens die door de huisarts in zijn dossier zijn vastgelegd zijn tevens geschikt voor een verwijsbrief, aangezien deze gegevens met een zelfde doel zijn vastgelegd, namelijk ter ondersteuning van de behandeling en verzorging van de patiënt. Zoals hierboven is beschreven dient de professionele-informatie overdracht volgens de Gedragsregels voor artsen wel te worden toegespitst op de vraagstelling waarmee een patiënt wordt verwezen. 
Bovendien dient de informatie zo volledig te zijn dat de zorg van een patiènt op een verantwoorde wijze door een andere beroepsbeoefenaar kan worden overgenomen. In art. 11 lid 1 Wet persoonsregistraties wordt bepaald dat gegevens aan een derde mogen worden verstrekt voorzover zulks voortvloeit uit het doel van de registratie, respectievelijk zulks wordt vereist ingevolge een wettelijk voorschrift of geschiedt met toestemming van de patiënt.

\subsubsection{Het recht op inzage}

Het recht op inzage geeft de patiënt de mogelijkheid om te zien welke gegevens zijn vastgelegd. Bovendien $\mathrm{kan}$ hij hierdoor gegevens laten verwijderen, aanvullen of corrigeren. Bij overdracht van zorg kunnen verwijs-en ontslagbrieven c.q. overdrachtformulieren via de patiënt worden uitgewisseld; de patiënt is dan postbode. Hierdoor kan hij de behoefte krijgen om de verslaglegging te lezen. Deze behoefte berust dan niet op wantrouwen jegens de beroepsbeoefenaar en de door hem mondeling verstrekte informatie, maar meer op een soort nieuwsgierigheid; wat zou ik hebben en wat staat me te wachten? De beroepsbeoefenaar zal op deze nieuwsgierigheid in kunnen spelen door de patiènt mondeling te informeren over informatie die hij in de verslaglegging opneemt. Hierdoor komt de patiênt bij het lezen van deze verslaglegging niet voor verrassingen te staan.

In deze paragraaf wordt ingegaan op de vragen wie inzage verstrekt en op welke wijze de patiënt inzage kan krijgen. Bovendien wordt ingegaan op de vragen of de patiënt recht heeft op het krijgen van afschriften en het recht heeft geschriften te corrigeren, aan te vullen, te verwijderen of te vernietigen.

\section{* Wie verstrekt inzage?}

Bij overdracht van zorg kan de hulpverlener, die informatie verstrekt aan een collega die werkzaam is in het andere echelon, de patiënt de mogelijkheid van inzage geven in de verwijs- en ontslagbrieven, c.q. overdrachtformulieren. Ook zou de hulpverlener die de informatie ontvangt en op dat moment verantwoordelijk is voor de zorg, inzage kunnen verstrekken. Zo kan bijvoorbeeld een huisarts na ontslag de patiënt inzage geven in de ontslagbrief van de specialist, mede omdat deze brief wordt opgenomen in het dossier van de patiënt.

Dit uitgangspunt sluit aan bij het Voorontwerp geneeskundige behandelingsovereenkomst waarin wordt bepaald dat de hulpverlener de inzage verstrekt (art. $1653 \mathrm{k})$. Dit is de hulpverlener die op dat moment verantwoordelijk is voor de zorg van een patiënt.

\section{* Wijze van inzage}

Inzage kan op twee manieren worden verstrekt, direct en indirect via een vertrouwenspersoon. Van deze laatste mogelijkheid kan gebruik worden gemaakt indien. de hulpverlener rechtstreekse inzage door de patiënt wil voorkomen, omdat hij denkt dat de patiënt hierdoor schade kan oplopen.

Noch het Voorontwerp geneeskundige behandelingsovereenkomst (art. 1653k) noch de Wet persoonsregistraties (art. 29) kennen bij het recht op inzage een therapeutische exceptie. Kennelijk waardeert de wetgever het belang dat een patiënt inzage moet kunnen hebben in de hem betreffende medische gegevens hoger dan de mogelijke schade die op dat moment nog zou kunnen ontstaan - nadat (of omdat) 
het informatieverkeer blijkbaar niet bevredigend is werlopen - doordat de patiënt geschokt zou zijn vanwege de gegevens waarvan hij kennis neemt. Als een patiënt bij wie in het stadium van de informatieverstrekking de therapeutische exceptie is toegepast later om inzage vraagt, doet de hulpverlener er verstandig aan om met de patiënt te owerleggen en alsnog genuanceerd en deugdelijk toegelicht de niet verstrekte informatie te geven.

Op het recht op inzage is wettelijk slechts eên beperking toegestaan. Als kan worden voorzien dat het verstrekken van inzage of afschrift van bepaalde gegevens aan de patiênt de persoonlijke levenssfeer van een derde zou schaden, dient de hulpverlener deze gegevensverstrekking achterwege te laten (art. 16531 lid 2).

Het inzagerecht strekt zich niet uit tot de werkaantekeningen van de hulpverlener. Deze moet de mogelijkheid hebben om persoonlijke indrukken en voorlopige opvattingen aan het papier toe te vertrouwen, om ze in een volgend stadium van onderzoek of behandeling nog eens te kunnen raadplegen. Dergelijke nog niet geobjectiveerde medische gegevens zijn in beginsel niet voor derden bestemd. Verwijs- en ontslagbrieven c.q. owerdrachtformulieren dienen evenwel geobjectiveerde informatie te bevatten ten behoeve van de arts die de verantwoordelijkheid voor de zorg van een patiënt overneemt en kunnen derhalve niet tot de werkaantekeningen worden gerekend.

\section{* Recht van de patiënt op afschriften}

Bij overdracht van zorg kan het voorkomen dat de patiënt een afschrift wil van zijn verwijs- en/of ontslagbrief c.q. overdrachtformulier. Voor het verstrekken van een afschrift mag de hulpverlener de kostprijs in rekening brengen (Voorontwerp geneeskundige behandelingsovereenkomst art. $1653 \mathrm{k}$ ). Volgens de Wet persoonsregistraties (art. 36) mogen de kosten niet hoger zijn dan een bij of krachtens algemene maatregel van bestuur vast te stellen bedrag.

\section{* Het recht op correctie, aanvulling, verwijdering en vernietiging}

Bij overdracht van zorg kan de patiënt de behoefte hebben om gegevens in zijn verwijs- en/of ontslagbrief c.q. overdrachtformulier te corrigeren, aan te vullen, te verwijderen of te vernietigen. Zo kan het voorkomen dat een patiënt bij het lezen van zijn verwijsbrief tot de conclusie komt dat daarin naar zijn idee relevante informatie ontbreekt of dat er juist informatie in staat die geen betrekking heeft op zijn huidige gezondheidsprobleem. De patiënt zou kunnen overwegen om de ontbrekende informatie alsnog mondeling te verstrekken. De vraag is of deze informatie net zo overtuigend overkomt - en bovendien niet verloren gaat - als de door de arts of verpleegkundige schriftelijk verstrekte informatie. Uitgangspunt is dat de beroepsbeoefenaar het belang van de patiënt dient te respecteren door ontbrekende informatie aan te vullen en onjuiste informatie, of irrelevante informatie respectievelijk te corrigeren en te verwijderen.

In de toekomstige wetgeving wordt het recht op aanvulling geregeld in artikel $1653 \mathrm{i}$ lid 2 van het Voorontwerp geneeskundige behandelingsovereenkomst; de hulpverlener dient een door de patiënt afgegeven verklaring met betrekking tot de aantekeningen toe te voegen aan de gegevens die hij omtrent de gezondheid van 
de patiënt en de diens inziens uitgevoerde verrichtingen aantekent. Het recht op aanvulling of verwijdering wordt toegekend in de Wet persoonsregistraties (art. 31). Strikt genomen gaat het daar niet om een recht zonder meer omdat de houder van de registratie de mogelijkheid heeft te beslissen in hoeverre hij aan dat verzoek voldoet. In geval van verschil van mening zal de rechter moeten oordelen (Leenen 1988, p. 266). Bovendien is wettelijk bepaald dat de beslissing tot verbetering, aanvulling of verwijdering zo spoedig mogelijk wordt uitgevoerd (WPR art. 31 lid 3).

In het Voorontwerp geneeskundige behandelingsovereenkomst (art. 1653j lid 2) wordt bepaald dat het verzoek om vernietiging van bescheiden binnen een jaar dient te worden ingewilligd. Voor overdracht van zorg heeft een dergelijke bepaling geen betekenis aangezien de informatie in korte tijd moet worden uitgewisseld. Vernietiging blijft overigens achterwege voorzover zwaarwegende belangen van de patiënt, de hulpverlener, een derde of de volksgezondheid dit moodzakelijk maken, alsmede indien daarover tussen de patiënt en de hulpverlener overeenstemming bestaat (art. 1635j lid 3).

\subsubsection{Samenvatting}

\section{* Recht op informatie}

Degene die verantwoordelijk is voor de verpleging c.q. behandeling van de patiènt is ook verantwoordelijk voor de informatie aan de patiënt. Deze norm komt terug in het Voorontwerp geneeskundige behandelingsovereenkomst. De informatie dient volgens het Voorontwerp geneeskundige behandelingsovereenkomst betrekking te hebben op aard en doel van het onderzoek of de behandeling die de hulpverlener mogelijk acht, over de te verwachten gevolgen en de risico's daarvan voor de gezondheid van de patiënt, over andere methoden van onderzoek of behandeling die in aanmerking komen, alsmede over de staat en de vooruitzichten met betrekking tot diens gezondheid voor wat betreft het terrein van onderzoek of behandeling.

Bij verwijzing dient de huisarts de patiënt voor te bereiden op hetgeen hem na de verwijzing te wachten staat. Over punten waarover onzekerheid bestaat zullen eventuele schattingen in redelijkheid op grond van de professionele standaard moeten kunnen worden verantwoord. De informatie van de wijkverpleegkundige kan betrekking hebben op de wijze van verzorgen in het ziekenhuis en het eventueel taak- of patiëntgericht verplegen. Zowel huisarts als wijkverpleegkundige dienen de patiënten te informeren omtrent de informatie-overdracht atan collega's werkzaam in het andere echelon.

De informatie bij ontslag, die door de specialist wordt verstrekt, heeft betrekking op het genezingsproces, op leefregels en op risicobeperking. Bovendien dient de patiënt geïnformeerd te worden over het inschakelen van derden en de daarbij verstrekte informatie. De ziekenhuisverpleegkundige kan de patiënt informeren omtrent de noodzaak en eventuele mogelijkheden van wijkverpleegkundige hulp. Indien wordt besloten om wijkverpleegkundige zorg aan te wragen dient de patient geïnformeerd te worden over de informatie-overdracht die plaatsvindt tussen 
ziekenhuis- en wijkverpleegkundige.

Informatie dient volgens het Voorontwerp geneeskundige behandelingsovereenkomst altijd te worden verstrekt, tenzij de hulpverlener het beter acht om de patiênt niet te informeren, bijvoorbeeld omdat hij veronderstelt dat de patiënt, door de informatie, nadeel kan ondervinden. In de literatuur wordt tegen het soepel hanteren van de therapeutische exceptie gewaarschuwd omdat dat het recht op informatie zou uithollen.

De patiënt kan de hulpverlener verzoeken hem niet te informeren. De hulpverlener moet dit verzoek respecteren behoudens voorzover hij, gelet op de aard van de verrichtingen, de informatie noodzakelijkerwijs aan de patiënt dient te verstrekken.

De informatie kan de patiënt mondeling, maar op verzoek van de patiënt, ook schriftelijk worden verstrekt.

* Toestemmingsvereiste

De toestemming van de patiënt is expliciet vereist voor de verwijzing naar het ziekenhuis, aangezien sprake is van overdracht van verantwoordelijkheid voor de zorg van een patiënt. Indien de patiënt instemt met de verwijzing impliceert dit de toestemming voor de bijbehorende informatie-overdracht.

Voor ontslag uit het ziekenhuis is de toestemming van de patiënt niet vereist, het is een beslissing van de specialist.

De patiënt dient in vrijheid zijn toestemming te geven of te kunnen onthouden nadat hij voldoende inzicht heeft verkregen in de consequenties van zijn toestemming.

Bepalingen inzake het schriftelijk vastleggen van de toestemming voor de gegevens-overdracht vindt men terug in de Wet persoonsregistraties.

\section{* Recht op vrije keuze}

Bij verwijzing naar het ziekenhuis kiest de patiënt voor een bepaalde specialist en/of ziekenhuis. Deze keuze impliceert een eventuele opname op een bepaalde verpleegafdeling en de verzorging door de daar werkzame verpleegkundigen. Bij ontslag is de keuze van de patiënt niet echt aan de orde ${ }_{n}$ hij keert in principe terug naar zijn huisarts. De keuze van een bepaalde wijkverpleegkundige is veelal beperkt tot de verpleegkundigen die werkzaam zijn in een bepaalde wijk en/of samenwerken met de betreffende huisarts.

\section{* Recht op informationele privacy}

Bij overdracht van zorg ligt het accent van de privacybescherming bij de gegevensuitwisseling. Hierbij moeten 4 algemene beginselen worden aangehouden. Bij overdracht van zorg kunnen de belangen van de hulpverlener om bepaalde gegevens over te dragen - bijwoorbeeld om de continuitteit van zorg te garanderen - nooit zo groot zijn dat hiervoor het recht van de patiënten op geheimhouding met wijken. In de verwijs- en ontslagbrieven c.q. overdrachtformulieren dienen de gegevens doelgericht te worden verzameld en vastgelegd, waarbij het doel van de 
registratie aanvaardbaar is en duidelijk is omschreven. Alleen die gegevens mogen uit het dossier van de patiënt worden uitgewisseld die voor het behandelingsdoel relevant zijn.

\section{* Het recht op inzage}

Het Voorontwerp geneeskundige behandelingsovereenkomst bepaalt dat de hulpverlener inzage dient te verstrekken. Bij overdracht van zorg is het voor de patiènt van belang om te weten bij welke hulpverlener hij om inzage in verwijs- en ontslagbrieven c.q. overdrachtformulieren kan verzoeken. Dit kan zowel bij degene zijn die de informatie verstuurd als bij degene die de informatie ontvangt.

Zowel het Voorontwerp geneeskundige behandelingsovereenkomst als de Wet persoonsregistraties bepalen dat de patiënt direct toegang heeft tot zijn gegevens.

De patiënt heeft volgens het Voorontwerp geneeskundige behandelingsovereenkomst recht op inzage in de verslaglegging, behoudens voorzover dit de persoonlijke levenssfeer van een derde zou schaden. Ook de Wet persoonsregistraties erkent dit recht op inzage. Bij overdracht van zorg kan het wan belang zijn om informatie over een derde, bijvoorbeeld een familielid te vermelden in een verwijsbrief. Indien de privacy van dit familielid wordt geschaad, kan dit een reden zijn waarom het verzoek van de patiënt om inzage kan worden geweigerd.

De patiënt heeft volgens de wet recht op afschriften, eventueel tegen betaling van de kostprijs.

Het recht op correctie, aanvulling en verwijdering is wettelijk vastgelegd in de Wet persoonsregistraties. Tevens heeft de patiënt volgens het Voorontwerp geneeskundige behandelingsovereenkomst het recht op vernietiging van bescheiden, doch vernietiging blijft achterwege indien zwaarwegende belangen van de patiënt, de hulpverlener, een derde of de volksgezondheid dit noodzakelijk maken.

Tenslotte heeft de patiënt, volgens het Voorontwerp geneeskundige behandelingsovereenkomst, het recht om een eigen verklaring met betrekking tot de aantekeningen aan de verslaglegging van de hulpverlener toe te voegen. 


\section{OPVATTINGEN EN ERVARINGEN TEN AANZIEN VAN HET OVERDRACHTSPROCES}

\subsection{Inleiding}

In dit hoofdstuk wordt ingegaan op de opvattingen en ervaringen van patiènten, artsen en verpleegkundigen met betrekking tot de rechten van patiènten bij overdracht van zorg. Om redenen die staan beschreven in het tweede hoofdstuk, zijn interviews gehouden die volgens de kwalitatieve onderzoeksmethode zijn geanalyseerd. Doel van deze onderzoeksfase was het verkrijgen van inzicht in de aard van het verschijnsel overdracht wan zorg en de wijze waarop geinterviewden het overdrachtsproces interpreteerden.

$\mathrm{Na}$ een beschrijving van de gehanteerde onderzoeksmethode worden de resultaten uit dit deel van het onderzoek belicht. In hoofdstuk 5 worden de resultaten uit de interviews geprojecteerd op het in het vorige hoofdstuk beschreven juridische kader.

\subsubsection{Onderzoeksmethode}

Om inzicht te krijgen in het overdrachtsproces wilden wij in eerste instantie een aantal patiënten volgen en observeren in hun gang naar en uit het ziekenhuis. Tegen het verrichten van een afstandelijke observatie' bestond een drietal bezwaren.

Een praktisch bezwaar was het verwachte gebrek aan medewerking van de kant van de hulpverleners. In onderzoeken over onder andere informatieverstrekking door de arts en de betrokkenheid van de patiënt tijdens spreekuren in de huisartsenpraktijk of op een polikliniek is wel gebruik gemaakt van afstandelijke observatie, maar het betrof meestal een beperkt aantal onderzoekslokaties. De betrokken hulpverleners hadden hun toestemming voor aanvang van het onderzoek gegeven. In dit onderzoek konden wij wijkverpleegkundigen, ziekenhuisverpleegkundigen en specialisten niet van te voren om toestemming vragen, aangezien zij, afhankelijk van het probleem van de patiënt, bij het onderzoek zouden worden betrokken. Bovendien zouden de patiënten uit verschillende delen van Nederland afkomstig zijn en derhalve met verschillende ziekenhuizen c.q. hulpverleners te maken hebben.

"Maso (1987, p.55) definieen afstandelijke observatie als: "het zorgvuldig en aandachtig. gadeslaan van gedragingen waarin onderzoekers zijn geïnteresseerd, waarbij deze gedragingen op geen enkele wijze het resultaat zijn van de activiteiten van onderzoekers, terwijl ze daaraan ook niet deelnemen". 
Het tweede praktische bezwaar was de relatief grote tijdsinvestering ten opzichte van het resultaat. Dit kwam enerzijds omdat niet elk gesprek op het spreekuur over de verwijzing of het ontslag van de patiënt gaat. Er zouden dus relatief veel gesprekken geobserveerd moeten worden om inzicht te krijgen in het gedrag van betrokkenen bij verwijzing, opname en ontslag van een patiënt. Deze gesprekken zouden bovendien in de spreekkamer, maar ook bij patiënten aan het bed - thuis en in het ziekenhuis - plaatsvinden, hetgeen extra tijd zou kosten. Verder zouden naast observaties ook nog interviews moeten worden afgenomen om een meer valide beeld te krijgen van de werkelijkheid. Tijdens deze interviews zou de onderzoeker na kunnen gaan of zijn interpretatie van wat hij gezien heeft overeenkomt thet de opvattingen en ervaringen van betrokkenen.

Een inhoudelijk bezwaar van afstandelijke observatie was dat de aanwezigheid van de onderzoeker tijdens verwijs-, opname en ontslaggesprekken invloed zou kunnen hebben op de "dagelijkse gang van zaken". In de praktijk blijkt echter dat geobserveerden na verloop van tijd aan de observator wennen of uit noodzaak "terugvallen" in hun normale gedragingen.

In dit onderzoek zijn in twee rondes rond een tiental overdrachtssituaties interviews gehouden met betrokken patiënten, huisartsen, specialisten, wijk- en ziekenhuisverpleegkundigen; het zogenaamde "stertetje" (figuur 4.1). Bij deze vorm van dataverzameling is er sprake van data-triangulatie, hetgeen betekent dat diverse data-bronnen zijn aangeboord om inzicht te krijgen in het onderzoeksobject (Smaling 1987, p. 293). Door met patiënten, artsen en verpleegkundigen uit een casus te praten over het overdrachtsproces zou hiervan een vollediger beeld kunnen worden verkregen.

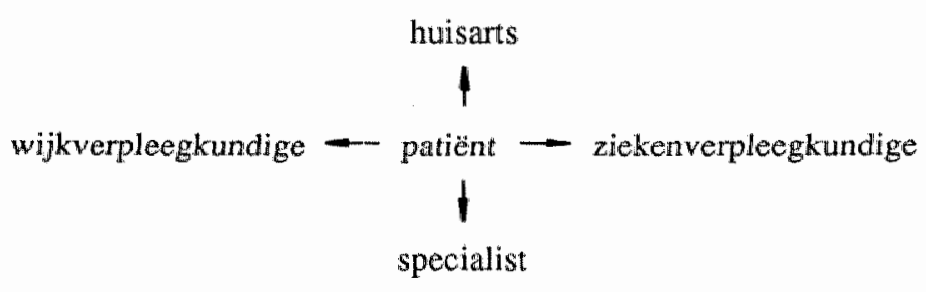

Figuur 4.1 Samenstelling casus in de vorm van een sterretje.

Het interviewmateriaal uit de eerste ronde zou dienen voor de opbouw van het interview in de tweede ronde. In de eerste ronde is gekozen voor vrije-interviews. Bij dit type interview hanteert de interviewer geen vragenlijst of een lijst met onderwerpen waar het gesprek over moet gaan (Segers 1977, p. 217). Hierbij had ik de mogelijkheid om me enigszins confronterend op te stellen door de respondenten te vragen inconsistenties te verduidelijken en door te vragen naar redenen van hun gedragingen en opvattingen. Zo antwoordden huisartsen op de vraag naar hun mening over "het recht van de patiënt op informatie", dat zij dit een belangrijk 
recht vonden en dat zij de patiënt altijd informeerden. Als later in thet gesprek bleek dat een huisarts de patiënt niet expliciet inlichtte over de informatie die hij over de patiënt aan de specialist verstrekte, werd gevraagd hoe de desbetreffende huisarts in een dergelijke situatie het recht op informatie van de patiënt respecteerde. Ook werd gevraagd waarom thij de patiënt hier niet over informeerde.

De interviews in de tweede ronde hadden het karakter van een focused-interview. Bij dit type vraaggesprek hanteert de interviewer geen vragenlijkst, maar stelt vragen aan de hand van een lijst van onderwerpen. Deze topics waren voortgekomen uit de interviews in de eerste ronde. Over de opbouw van de interviews wordt in paragraaf 4.2 .3 nader ingegaan.

\subsubsection{Selectie van onderzoekseenheden}

Nadat voor het houden van interviews was gekozen kon worden overwogen wie per casus het eerst zou worden geïnterviewd: de patiënt, de huisarts, de specialist, de wijk- of ziekenhuisverpleegkundige. Om de chronologische volgorde van het overdrachtsproces binnen de opbouw van de interviews te handhaven werd besloten om met de huisarts te beginnen. Hiermee werd het probleem van een "onvolledig sterretje" - dat wil zeggen, niet alle respondenten in een casus deden met het onderzoek mee - ondervangen; wij benaderden net zolang verschillende huisartsen met het verzoek of zij met het onderzoek mee wilden doen, totdat het gewenste aantal was bereikt (in de eerste en tweede ronde respectievelijk 5 en 6 huisartsen). Bovendien kon de huisarts worden verzocht om patiënten te selecteren die aan een aantal criteria voldeden. In het nu volgende zal worden aangegeven op welke wijze de onderzoekspopulatie is samengesteld.

\section{* De huisartsen}

De huisartsen in de eerste ronde zijn geselecteerd op grond van sexe, leeftijd en praktijkvorm. Hierbij werd gestreefd naar een gevarieerde groep huisartsen en niet naar een representatieve steekproef van Nederlandse huisartsen ${ }^{2}$. Wij waren immers geïnteresseerd in de aard van bepaalde verschijnselen in plaats van in de mate waarin die verschijnselen voorkwamen (Maso 1987, p. 12; Wester 1987, p. 72). Tevens konden deze variabelen worden teruggevonden op de adressenlijst van Nederlandse huisartsen die was verkregen bij het Nederlands Instituut voor onderzoek wan de Eerstelijnsgezondheidszorg (Nivel). Het feit dat het Nivel bereid was om voor het doel van dit onderzoek een adressenlijst te verstrekken zou de huisartsen mogelijk motiveren om mee te doen.

Tien huisartsen moesten worden aangeschreven om er uiteindelijk 5 over te houden, 1 vrouwelijke en 4 mannelijke huisartsen. Redenen die artsen gaven om niet mee te doen hadden betrekking op: geen patiënten kunnen leveren (1), al aan een ander onderzoek meedoen (2), al te vala met onderzoeksvragen benaderd (1) en pas begonnen als huisarts (1).

De leeftijd van de huisartsen die meededen aan het onderzoek varieerde tussen de

Steekproeven uit universa stellen ons in staat tot uitspraken "over de mate waarin cen verschijnsel voorkomt, over zijn geografische en sociale variatie en over' de typische vormen die het aanneemt (Philipsen 1969, p.17). 
35 en 50 jaar. De praktijkvormen verschilden: drie solopraktijken en drie associaties. Alle lokaties lagen in de grote steden in de randstad.

In de tweede ronde werd besloten om huisartsen te benaderen die vermeld staan in het Geneeskundig adresboek 1987. De reden hiervoor was dat het aanvragen van een nieuwe adreslijst bij het Nivel opnieuw tijd zou kosten. Bovendien bleek dat van de Nivellijst al twee huisartsen aan een ander onderzoek meededen. Een andere huisarts was al te vaak met onderzoeksvragen benaderd. Ook leverde de adressenlijst van het Nivel vooral adressen op van mannelijke huisartsen die werkzaam waren in de Randstad. Kortom, het verwachte positieve effect van de Nivellijst viel minder gunstig uit dan was verwacht. Door gebruik te maken van het Geneeskundig adresboek werd de keuze mogelijkheid vergroot.

Aangezien in het adresboek alleen plaats van vestiging en de sexe van de huisarts vermeld staan, kon op grond van deze twee variabelen een tweede groep huisartsen worden samengesteld. De praktijkvorm speelde in de tweede ronde geen rol bij de selectie.

Uit de resultaten van de eerste ronde bleek dat alleen huisartsen bij het onderzoek waren betrokken die, wegens de lokatie van hun praktijk, bij de verwijzing uit verschillende ziekenhuizen konden kiezen. Op grond hiervan wilden wij in de tweede ronde ook huisartsen benaderen die in minder "ziekenhuis-dichte" regio"s werkzaam waren.

Tevens bleek dat huisartsen bij verwijzingen naar academische ziekenhuizen de patiënt verwezen naar een bepaald specialisme in plaats van naar een specifieke specialist, meestal omdat ze bepaalde specialisten niet persoonlijk kenden en ook niet op de hoogte waren van persoonlijke kwaliteiten en sub-specialisaties van specialisten. In de tweede ronde wilden wij nagaan of huisartsen ook naar specialisten uit perifere ziekenhuizen naar een specialisme, in plaats van op een naam van een specialist verwijzen. Daarom zijn in de tweede ronde ook huisartsen in het onderzoek betrokken die niet zo vaak met academische ziekenhuizen te maken hadden.

Vijftien huisartsen moesten in de tweede ronde telefonisch worden benaderd om er zes over te houden, 3 vrouwelijke en 3 mannelijke huisartsen. Redenen voor de non-respons waren:

- geen tijd en te druk (4)

- niet geînteresseerd zijn (2)

- nooit meedoen aan onderzoek (1)

- overwerkt zijn (1)

- zelf geen patiënten verwijzen, doch werkzaam zijn als

homeopatisch arts die door patiënten geconsulteerd wordt (1)

Ook in de tweede ronde varieerde de leeftijd van de huisartsen tussen de 30 en 50 jaar. Drie huisartsen werkten in een associatie, een huisarts in een gezondheidscentrum en een in een therapeuticum. Van de 6 huisartsenpraktijken lag en een in een kleine stad buiten de randstad en een in een kleine plaats in Brabant. 
De vraag kan worden gesteld of bij de selectie van de huisartsen theoretical sampling is toegepast. Hiervan is sprake als men een empirisch onderzoek zo inricht, dat men diverse theorieën kan toetsen en vergelijken (Smaling 1987, p. 293). In dit onderzoek is nog geen sprake van een theorie over het verwijsgedrag van huisartsen. Strauss (1987, p. 16) zegt over theoretical sampling: "The researcher, after previous analysis, is seeking samples of population, events, activities guided by his or her emerging (if still primitive) theory". In dit onderzoek is op grond van nieuwe inzichten over relaties tussen huisartsenvariabelen en het verwijsgedrag, het verzamelen van gegevens onder huisartsen aangepast.

\section{* De patiënten}

Elke huisarts werd verzocht om uit zijn patiëntenbestand 5 patiënten te selecteren.

De patiëntenselectie was gebaseerd op de volgende criteria:

- to: cordelen en uiten in staat;

- een of meer keren in het ziekenhuis opgenomen geweest, waarvan de laatste keer niet langer dan drie maanden geleden;

- Nederlandse taal mondeling en schriftelijk beheersen;

- wijkverpleegkundige zorg hebben gehad.

Het eerste en derde criterium moesten ervoor zorgen dat huisartsen patiënten selecteerden die het doel van het onderzoek konden begrijpen en die hun eigen ervaringen en opvattingen konden verwoorden. Het tweede criterium kon ervoor zorgen dat patiënten, maar ook verpleegkundigen en specialisten zich het overdrachtsproces van een bepaalde patiënt zouden herinneren. Het laatste criterium was van belang omdat ik ook de overdracht van zorg tussen wijk- en ziekenhuisverpleegkundigen in het onderzoek wilde betrekken. Voor de meeste huisartsen leverden deze criteria problemen op omdat te weinig patiënten aan de criteria voldeden. Hierdoor had de onderzoeker niet de mogelijkheid om uit de vijf door de huisarts geselecteerde patiënten één patiënt te kiezen en moest veelal genoegen worden genomen met én patiënt uit een huisartsenpraktijk. Men zou kunnen veronderstellen dat hierdoor een vertekening in de onderzoeksresultaten is opgetreden. Aangezien echter uit de resultaten blijkt dat het overdrachtsproces niet altijd even voorbeeldig verloopt lijkt deze veronderstelling niet aannemelijk.

\section{* De specialisten en verpleegkundigen}

Voor de selectie van specialisten, wijk- en ziekenhuisverpleegkundigen zijn geen criteria geformuleerd. Tijdens de interviews met de patiënten werd gevraagd door welke specialist zij in het ziekenhuis waren behandeld en met welke ziekenhuisverpleegkundigen zij het meeste contact hadden gehad. Ook werd hen gevraagd wie hun wijkverpleegkundige was. In het kader van dit onderzoek is van deze werkwijze niet afgeweken. Kortom, de zorgvuldige selectie zoals die bij de huisartsen en patiënten heeft plaats gevonden, speelde bij de selectie van specialisten geen rol.

De voordelen van een dergelijke opbouw en de gekozen volgorde van de onderzoekspopulatie waren:

- de privacy van de patiënt werd niet aangetast bij de werving;

- de respons van de specialisten was $100 \%$, omdat zij geen "spelbreker" wilden zijn; 
- we verkregen inzicht in de kennis van de huisarts over wijkverpleegkundige zorg; een aantal malen was de huisarts hier onvoldoende van op de hoogte en moest hij in het kader wan het onderzoek contact opnemen om zich nader te informeren, b.w. welke patiënten van hem bij de wijkverpleging in zorg waren;

- we verkregen inzicht in de (telefonische) bereikbaarheid van de specialist, huisarts, wijk- en ziekenhuisverpleegkundige. Een belangrijk aspect voor de communicatie tussen hulpverleners in het kader van overdracht van zorg.

De nadelen waren de volgende:

- het onderzoek nam veel (reis)tijd in beslag. Het bleek niet mogelijk om op een of twee dagen alle afspraken rondom een casus te maken, met als gevolg dat veel op en neer gereisd moest worden;

- oude tot zeer oude patiënten deden met het onderzoek mee, omdat de patiënten na opname wijkverpleegkundige zorg moesten hebben gehad. Hierdoor is geen inzicht verkregen in de opvattingen en ervaringen van niet bejaarde patiënten.

Tabel 4.2 Kenmerken respondenten

\begin{tabular}{|c|c|c|c|c|c|}
\hline & Pat & $\mathrm{Ha}$ & Spec & Wv & $\mathrm{Zv}$ \\
\hline \multicolumn{6}{|l|}{ Leeftijd } \\
\hline $20-34$ & -. & & & 4 & 3 \\
\hline $35-50$ & .. & 11 & 11 & 6 & 8 \\
\hline $51-70$ & 5 & & & & \\
\hline $70+$ & 6 & & & & \\
\hline \multicolumn{6}{|l|}{ Geslacht } \\
\hline $\operatorname{man}$ & 4 & 6 & 2 & 8 & 7 \\
\hline vrouw & 7 & 7 & 9 & 3 & 4 \\
\hline Randstad & 9 & 9 & 9 & 9 & 9 \\
\hline Overige steden & 1 & 1 & 2 & 1 & 1 \\
\hline Kleine plaatsen & 1 & 1 & -- & 1 & 1 \\
\hline
\end{tabular}

Afkortingen: pat $=$ patiënt ${ }_{n}$ ha $=$ huisarts,, spec $=$ specialist,$w \mathrm{v}=$ wijkverpleegkundige, $\mathrm{zv}=$ ziekenhuisverpleegkundige

\subsubsection{De interviews}

De interviews kunnen worden verdeeld in twee rondes. In de eerste ronde hadden zij het karakter van het vrije-interview. Vanuit de resultaten uit de eerste ronde konden de topics van de interviews in de tweede ronde worden opgestell (focused-interview). In paragraaf 4.2 .1 is beschreven waarop de keuze voor vrije- en focused interviews is gebaseerd. 
De interviews duurden ongeveer een uur. Alle interviews met de patiènten werden bij de patiënt thuis afgenomen. Indien de partner of een ander familielid de patiënt vergezelde bleef deze ook tijdens het interview aanwezig. Ik heb overwogen om "derden" te verzoeken de ruimte te verlaten, maar aangezien tijdens de gesprekken bleek dat de patiënt zich soms weinig van de overgang van de eerste- naar de tweede lijn kon herinneren, werd besloten eventuele partner of ander familielid bij het interview te betrekken. De interviews met de verpleegkundigen werden in een ruimte op de afdeling of in het wijkgebouw afgenomen.

De interviews werden op geluidsband opgenomen en in de eerste ronde door de onderzoeker uitgetypt. In de tweede ronde werden de interviews uitgetypt door een onderzoeksassistente. $\mathrm{Zij}$ bracht hierbij in de tekst aan waar volgens haar in het interview een bepaalde passage overging naar een ander topic. Ik voorzag de verschillende passages van trefwoorden. Deze analyse heb ik tweemaal, met een tussenperiode van een week, uitgevoerd. De reden hiervoor was dat ik wilde controleren of ik de juiste trefwoorden plaatste bij de verschillende scènes, ik was namelijk de enige onderzoeker die de scènes van trefwoorden voorzag. In de tweede interview ronde waren de trefwoorden uit de eerste ronde mijn topics. Het computerprogramma Kwalitan werd gebruikt bij het selecteren van bepaalde passages uit de werschillende interwiews (Peters, 1987).

\section{* Opbouw van de interviews}

Gestart werd met vragen met een weinig bedreigend karakter om een zekere mate van openheid van de kant van de ondervraagde te bereiken. Bovendien legde ik de geïnterviewden duidelijk uit dat de verkregen antwoorden niet zouden worden teruggekoppeld naar de overige betrokkenen in de casus. Tijdens de analyse kon worden vastgesteld dat naarmate het gesprek vorderde inderdaad de vertrouwelijkheid toenam, resulterend in opmerkingen dat "een antwoord eigenlijk niet bestemd was voor het cassettebandje". Ook werden in de loop van het gesprek steeds vaker "ik-antwoorden" gegeven in plaats van relatief afwijkende, vage of anderszins minder zeggende reacties. Hierbij kan worden opgemerkt dat artsen dit sneller doen dan verpleegkundigen die meer spreken over "wij". Patiënten daarentegen spreken uitsluitend over hun persoonlijke ervaringen en opvattingen. Opvallend was dat ondanks dat de patiënten in hun verhalen duidelijk punten van kritiek naar voren brachten, zij toch regelmatig opmerkten dat ze zeer tevreden en goed te spreken waren over de verleende zorg.

De vragen in de eerste ronde waren zeer open (vrije interviews). Gevraagd werd hoe patiënten werden verwezen en wat er bij de verwijzing kwam kijken. De interviews hadden een oriënterend karakter waarbij niet in elk interview dezelfde topics werden besproken. De respondent mocht bepalen wat hij belangrijk vond bij het overdrachtsproces en op welke wijze hij dacht dat rechten van patiënten hier een rol in speelden. De interviews hadden wel ongeveer dezelfde opbouw, na een open begin werd aan het eind van het gesprek op enkele specifieke rechten van patiënten ingegaan, zoals het recht op informatie, het toestemmingsvereiste, het recht op vrije keuze, het recht op informationele privacy en het recht op inzage. De reden hiervoor was dat deze rechten het juridisch kader vormden van het on- 
derzoek en dat in de interviews werd nagegaan in hoeverre deze rechten bij overdracht van zorg werden gerespecteerd.

In de tweede ronde werden aan de respondenten vragen gesteld die gebaseerd waren op de resultaten van de eerste ronde. De topics hadden betrekking op:

- globale beschrijving opname in c.q. ontslag van een patiënt uit het ziekenhuis

- informatieverstrekking aan de patiênt bij verwijzing

- de beslissing tot verwijzing

- mondelinge en schriftelijke professionele informatie-overdracht bij verwijzing

- relatie/contacten eerste en tweede lijn

- bezoeken hulpverleners aan het ziekenhuis

- mondeling en schriftelijke professionele informatie-overdracht bij ontslag

- informatieverstrekkíng aan de patiënt bij ontslag

- organisatie van de nazorg

- contacten vanuit het ziekenhuis met huisarts en wijkverpleegkundige

$\mathrm{Na}$ deze beschrijving over opvattingen en ervaringen ten aanzien van het overdrachtsproces, werd aan alle hulpverleners gevraagd waar zij aan dachten bij beroepsregels, of deze op schrift waren gezet en of dit wel eens gesprekstof was onder collega's. Daarna werd bij alle respondenten nogmaals ingegaan op het recht op informatie, het toestemmingsvereiste, het recht op vrije keuze, het recht op informationele privacy en het recht op inzage opdat gekeken kon worden of de respondent eenduidig was in zijn antwoorden. Hierbij werd bovendien gevraagd of het desbetreffende recht een rol speelde bij overdracht van zorg. Tenslotte werd nader ingegaan op de casus van de patiënt, voorzover deze nog niet ter sprake was gekomen. In veel gevallen was het moeilijk om gedetailleerd op het overdrachtsproces van een bepaalde patiënt in te gaan. In de volgende paragraaf zal hier nader op worden ingegaan.

\section{* Analyse-in-eerste-instantie}

De analyse van kwalitatief verzameld materiaal vergt een afzonderlijke aanpak. Hierbij wordt de dataverzameling, analyse en het relateren aan mogelijke theoretische inzichten voortdurend afgewisseld. Maso (1987, p. 81) onderscheid hierbij de analyse-in-eerste-instantie en de analyse-in-tweede-instantie. In het tweede hoofdstuk is hier al even bij stilgestaan. Bij de eerst genoemde analyse wordt alle kennis die is verworven tijdens het formuleren van de probleemstelling en onderzoeksopzet, evenals de gedachten tijdens het verzamelen, tussen hakjes gezet. Hierbij kunnen de volgende stappen worden onderscheiden:

1. De registratie en verslagen van de verschijnselen die in de onderzoeksituatie zijn aangetroffen worden verschillende malen bekeken en gelezen zonder poging tot verklaring.

2. Het beeld dat in de vorige stap is verkregen wordt verdiept en uitgebreid door het accent te leggen op de details van de verschijnselen.

3. De aangetroffen verschijnselen worden zo mogelijk verklaard door ze met elkaar in verband te brengen.

4. De al dan niet met elkaar in verband gebrachte verschijnselen worden onderzocht om te zien of ze én of meer onderwerpen of thema's vertegenwoordigen, die alleen of te zamen de betekenisvolle eenheid van die verschijnselen vormen. 
5. De werzamelde gegevens worden nog eens nagelopen om voor zover nodig de preciese betekenissen van die verschijnselen vast te stellen.

6. De gegevens worden nogmaals bekeken on te zien of ze inzicht kunnen verschaffen in een mogelijk antwoord op de voorlopige probleemstelling of in die probleemstelling zelf.

In dit onderzoek zijn in zowe $\rrbracket$ de eerste als tweede ronde de volgende stappen gezet. De woordelijk uitgeschreven interviews zijn verschillende malen herlezen en van trefwoorden voorzien (stap 1). Hierbij bleek dat overdracht van zorg gezien werd als een proces waarbij fasen kunnen worden onderscheiden zoals de opnameprocedure, de informatieverstrekking aan de patiënt bij overdracht van zorg, contacten tussen hulpverleners in de ziekenhuis- en thuissituatie, kennisgeving van de overdracht door hulpverleners onderling, schriftelijke informatie-overdracht, bezoek van huisarts en wijkverpleegkundige aan het ziekenhuis, bereikbaarheid van hulpverleners en de ontslagprocedure. Vervolgens is bij deze verschillende fases nagegaan op welke wijze de rechten van patiënten werden gerespecteerd (stap 2). Zo is bijvoorbeeld nagegaan op welke wijze huisartsen de patiënt informeerden over de schriftelijke informatie-overdracht aan collega's werkzaam in het andere echelon; welke woorden werden gebruikt, hoeveel tijd ervoor werd uitgetrokken, of de patiënt inzage kreeg in zijn gegevens etc. Hierbij is tevens nagegaan waarom huisartsen de patiënt op een dergelijke wijze informeerden (stap 3) en of deze wijze van informatieverstrekking specifiek was voor de informatie over de professionele informatie-overdracht tussen beroepsbeoefenaren in verschillende echelons (stap 4). Dit bleek het geval te zijn. Informatie aan de patiënt over bijvoorbeeld onderzoeks- en behandelingsmogelijkheden werd door huisartsen beschouwd als van een andere orde dan de informatie over de professionele informatie-overdracht. De patiënt had volgens hen recht om over eerstgenoemde geinformeerd te worden, terwijl informatie over de professionele-informatie-overdracht werd gezien als een aspect van hun professionele verantwoordelijkheid waar de patiënt niet bij betrokken diende te worden. Vervolgens is gekeken inhoeverre deze informatieverstrekking aan de patiënt consistent is met eerdere beweringen omtrent het recht op informatie van de patiënt (stap 5). Tenslotte is de analyse-in-eerste-instantie afgesloten met de bestudering van de gegevens met het oog op de probleemstelling. Hileruit bleek dat informatie over de professionele informatie-overdracht een apart onderdeel vormt in het totaal van de informatieverstrekking bij verwijzing en ontslag (stap 6).

Zoals reeds in het tweede hoofdstuk is beargumenteerd is een analyse-in-tweedeinstantie achterwege gelaten. Het materiaal dat met de interviews is verkregen is vergeleken met het juridisch kader. De indicaties die uit deze vergelijking naar voren kwamen, werden in de vorm van stellingen gepresenteerd aan een Delphipanel met de bedoeling na te gaan in hoeverre consensus kon worden verkregen ten aanzien van de voorwaarden woor owerdracht van zorg.

\subsubsection{Betrouwbaarheid en validiteit}

Uit de literatuurstudie van Smaling (1987, p. 273) komt naar voren dat door kwalitatieve methodologen ten aanzien van de validiteit en de betrouwbaarheid eisen worden gesteld die gedeeltelijk overeenkomen met de door kwantitatieve methodo- 
logen gestelde eisen. Smalling stelt: "Weliswaar worden deze termen door kwalitatieve methodologen soms verworpen, vermeden of door andere termen vervangen, maar de geloofwaardigheidsproblemen die ermee worden aangeduid keren in de een of andere worm steeds weer terug". In het nu volgende zal worden uitgegaan van het referentiekader van Smaling. Zijn studie berust op een analyse van verschillende methodologen waarbij hij uiteindelijk aangeeft wat de kwaliteitseisen betekenen woor kwalitatief onderzoek.

Achtereenvolgens zal worden ingegaan op de interne en externe betrouwbaarheid en de interne validiteit. De externe validiteit - ook wel generaliseerbaarheid genoend - wordt buiten beschouwing gelaten omdat de onderzoeksresultaten niet gebruikt worden voor het doen van generaliserende uitspraken. Bij de presentatie van de resultaten gaat het niet om hoeveel personen bepaalde verschijnselen beschijven, maar om de wijze waarop verschijnselen worden ervaren.

\section{* Betrouwbaarheid}

In kwalitatief onderzoek komt betrouwbaarheid bijna niet voor als een kenmerk van instrumenten anders dan de onderzoeker zelf. Smaling (1987, p. 276) stelt vast dat:

- betrouwbaarheid zelden of nooit voorkomt als interne consistentie, stabiliteit, parallellie of vergelijkbaarheid van vormen ten aanzien van het instrument;

- geen statistische modellen voor betrouwbaarheid gehanteerd worden;

- geen numerieke benaderingen van overeenkomst of overeenstemming tussen onderzoekers of observeerders voorkomen.

In kwalitatief onderzoek betekent betrouwbaarheid volgens Smaling herhaalbaarheid (of repliceerbaarheid, reproduceerbaarheid) van onderzoeksresultaten door andere onderzoekers (of observeerders, interviewers, etc.) in eenzelfde situatie met dezelfde methoden, of consistentie van verschillende observaties en andere bevindingen binnen een onderzoeker. Hierbij onderscheidt Smaling interne en externe betrouwbaarheid. Eerstgenoemde kan worden bevorderd door:

- beschrijvingen met zo min mogelijk interpretaties, inferenties weer te geven;

- samenwerking van meerdere onderzoekers die door discussie tot overeenstemming komen;

- samenwerking met onderzochten, participanten, die soms als arbiter kunnen optreden;

- confrontaties met andere onderzoekers of onderzoeksresultaten, dus "peer examination";

- mechanisering van het registreren van gegevens, bijvoorbeeld met video- en audiotapes;

- reglementering van de data-analyseprocedures.

Dit onderzoek is door slechts 1 onderzoeker uitgevoerd, waardoor discussies met andere onderzoekers en de z.g. "peer examination" niet mogelijk waren. Overwogen is om samen te werken met de onderzochten, door de resultaten uit de interviews aan hen terug te koppelen, waardoor zij als scheidsrechter zouden kunnen optreden. Hiervoor is uiteindelijk niet gekozen omdat dit voor mij, maar ook voor de onderzochten, een aanzienlijke tijdsinvestering zou betekenen. Derhalve hebben we gezocht naar andere methoden om de interne betrouwbaarheid te vergroten. 
Maso (1987, p. 67) stelt dat volkomen ongestructureerde interviews meer waarborgen bieden betrouwbare gegevens op te leveren dan wat meer gestructureerde. De reden hiervoor zou zijn dat de respondenten zich buj gestructureerde interviews zouden bepalen tot het onderwerp van de door de onderzoeker gestelde beginvraag. De beperkende rol zit in het feit dat de onderzoeker zich bij het stellen van deze vragen zou kunnen laten leiden door gevoelens of vooroordelen. Zoals reeds is beschreven, bestonden de interviews in de eerste ronde uit volkomen ongestructureerde interviews. In de tweede ronde waren de interviews opgebouwd rondom een aantal topics, maar ook tijdens deze gesprekken bepaalde de respondent voor een groot deel op welke topics het accent werd gelegd.

Door de interviews op geluidsband op te nemen en ze vervolgens letterlijk uit te typen, bevatten de beschrijvingen zo min mogelijk interpretaties. Bovendien is bij de analyse van de gegevens gebruik gemaakt van het computerprogramma Kwalitan. Dit programma kan gezien worden als een soort reglementering van het analyseproces, aangezien de voornaamste handelingen en activiteiten van de onderzoeker op een rij worden gezet (Peters 1987).

De verschillende scènes zijn tweemaal, met een tussenperiode van een week, door de onderzoeker van trefwoorden voorzien.

De vorming van bepaalde thema's vindt volgens Glaser en Strauss (1967, p. 23) plaats "from evidence". De indeling in scènes blijft echter gebonden aan de interpretaties van de onderzoeker. Diens subjectieve visie speelt dus wel degelijk een rol.

In dit onderzoek hebben de onderzoeker en de onderzoeksassistente - die had geholpen met het uittypen van de interviews - niet onafhankelijk van elkaar de verschillende passages ingedeeld en van trefwoorden voorzien, waardoor geen inzicht is verkregen in de betrouwbaarheid van de indeling en de trefwoorden.

Het computerprogramma Kwalitan gaf de garantie dat alle relevante passages rondorn een bepaald onderwerp uit de grote hoeveelheid gegevens snel geselecteerd en geprint konden worden. Bij het handmatig selecteren is de kans groot dat de onderzoeker bepaalde passages over het hoofd ziet.

Tenslotte zijn alle scènes, gebundeld rondom een bepaald thema, verwerkt tot een onderzoekswerslag, waarbij de onderzoeker bepaalde welke passages woordelijk ter illustratie van een bepaalde opvatting werden opgenomen. Ook hier speelt de interpretatie van de onderzoeker een belangrijke rol.

In dit onderzoek is ook aandacht besteed aan de externe betrouwbaarheid, ook wel de navolgbaarheid (Bleeker en Mulderij, 1984; Van IJzendoorn en Miedema, 1986) genoemd. Met dit laatste wordt aangegeven dat de lezer van het onderzoeksrapport alles kan "volgen" en ook beoordelen. Gezien de zorgvuldige beschrijving van de gevolgde werkwijze - bijvoorbeeld welke respondenten zijn benaderd en rondom. welke topics de interviews zijn gehouden - is aan het criterium van de externe betrouwbaarheid, gedefinieerd als navolgbaarheid, voldaan.

Externe betrouwbaarheid wordt ook wel als herhaalbaarheid omschreven (LeCompte en Goetz 1982). Sommige kwalitatieve onderzoekers menen dat een onderzoek. niet repliceerbaar is in de zin dat onderzoekers dezelfde resultaten verkrijgen. Zo 
menien Bogdan en Biklen (1982) dat verschillende onderzoekers op zich betrouwbaar kunnen zijn in de zin van zorgwuldig en volledig, maar dat ze toch tot verschillende resultaten kunnen komen, omdat ze nu eenmaal verschillen in interesses, achtergronden en theoretische perspectieven.

Samenvattend, in dit onderzoek zijn verschillende stappen ondernomen om de interne- en externe betrouwbaarheid te bevorderen. Daarbij is niet nagegaan of en inhoeverre inderdaad betrouwbare resultaten zijn verkregen.

\section{* Interne validiteit}

De interne validiteit in ruime zin - hieronder vallen de inhoudsvaliditeit, criterium gerelateerde validiteit, constructvaliditeit en interne validiteit-in-engere-zin is volgens Smaling (1987, p. 279) de mate waarin het onderzoek de vermelde eindresultaten, de getrokken conclusies rechtvaardigt. Smaling beschrijft negen bedreigingen van deze waliditeit.

1. Reactiviteit; dit is het fenomeen dat onderzochten zich onder de aanwezigheid van een onderzoeker anders kunnen gedragen, alleen al door het feit van de aanwezigheid op zich.

2. Onderzoekerseffecten; dit is de reactie van de onderzochte op de kenmerken, gedragingen en houdingen van de onderzoeker.

3. Onderzoekersbias; dit is de invloed van de onderzoekerskenmerken, -attitudes, -vooroordelen enz., op de waarnemingen, gegevens, interpretaties enz. van de onderzoeker.

4. Vervormingen door de methode; hierbij kan men denken aan dataverzamelingstechnieken zoals observatie, gesprekswoering. audio- en videorecording of analysemethoden zoals inhoudsanalyse of analytische inductie tijdens de dataverzameling.

5. Selectiviteit; de keuze van de bestudeerde situaties (tijdstip en respondenten) kan dusdanig select zijn dat eigenlijk alleen maar een scheef, onvolledig of geheel verkeerd beeld kan ontstaan.

6-8. Geschiedenis, groei of ontwikkeling en uitval vormen drie bedreigingen die zijn verbonden met het tijdsverloop. Externe gebeurtenissen en veranderingen bij de onderzochten kunnen in de loop van het onderzoek een beeld veranderen.

9. Subject-bias; hierbij gaat het om vooroordelen, vervormde of verkeerde uitspraken van onderzochten of informanten. Overigens is het niet zo dat de vervormde ideeën van de onderzochten steeds irrelevant zijn. Zo geldt: "if men define situations as real, they are real in their consequences" (Thomas 1928, p. 572; Denzin 1970).

ad 1 en 9

In dit onderzoek zijn de volgende stappen ondernomen om een aantal van deze bedreigingen tegen te gaan. Aangezien interviews zijn gehouden met respondenten vormt de reactiviteit geen wezenlijke bedreiging. De respondenten hebben hoogstens een mooier verhaal verteld dan wat ze werkelijk ervaren hebben (subjectbias). De patiënten wisten immers dat ik ook met de betrokken artsen en verpleegkundigen zou praten over hun overdracht. Zeker omdat een aantal patiënten nog onder behandeling stond of verzorging kreeg kan de angst voor "represaille" niet 
worden uitgesloten. Als remedie tegen deze bedreiging heb ik geprobeerd om de interviews open te beginnen om de werkelijkheid van de respondenten geen geweld aan te doen. Naderhand kwam ik op bepaalde aspecten uit het verhaal van de respondent terug, speciaal als het ging over het recht op informatie of andere rechten van patiënten. Tevens beloofde ik de respondenten dat ik de informatie niet zou terug koppelen naar andere betrokkenen.

\section{ad 2}

Het onderzoekerseffect kan een bedreiging hebben gevormd voor de validiteit. De respondenten wisten immers dat ik als onderzoeker werkzaam was bij de vakgroep Gezondheidsrecht. Hierdoor zouden de beroepsbeoefenaren zich kunnen hebben gemodelleerd naar mijn opvattingen, zonder dat ik deze had kenbaar gemaakt, het zogenaamde "Pygmalion-effect". De al eerder beschreven confronterende vragen kunnen deze bedreiging enigszins hebben beperkt.

\section{ad 3}

Ook de onderzoekersbias kan in dit onderzoek een rol hebben gespeeld. Het was voor mij als onderzoekster moeilijk om me te verplatsen in de verschillende culturen. Het gevaar dat ik hierbij een andere cultuur probeerde te begrijpen vanuit mijzelf of eigen cultuur was niet te voorkomen (personal equation). In de literatuur wordt gesteld dat het zoeken naar mensen die "outliners" zijn en het zoeken naar disconfirmerende gevallen de onderzoekersbias kan beperken. Gezien de geringe omvang van de onderzoekspopulatie bleek dit in beperkte mate mogelijk.

\section{ad 4}

De validiteit kan tevens zijn bedreigd door storingen op de interviewlokaties. De telefoontjes en de mensen aan de deur hebben de loop van het gesprek mogelijk beïnvloed (vervorming door methode). Daarnaast vormde de opname-apparatuur een storende factor. Zo nu en dan moest de cassette worden omgedraaid. Op zo'n moment moest het gesprek even worden onderbroken. Soms liep het gesprek gewoon door, waardoor informatie verloren ging. Zoals in paragraaf 4.2.3 uiteen is gezet, bleek de aanwezigheid van de opname-apparatuur de respondenten niet te weerhouden zich te uiten. Bij het uittypen van de interviews bleken een paar passages moeilijk te verstaan, waardoor deze gegevens schriftelijk miet konden worden vastgelegd. Ook het ontbreken van dit onderzoeksmateriaal wormt een bedreiging van de validiteit.

\section{ad 5}

De selectiviteit vormt vooral een bedreiging van de externe validiteit. De beschrewen casus geven in dit onderzoek een selecte weergave van enkele overdrachtssituaties. Dit komt enerzijds door de selectiecriteria van de patiênt, anderzijds hebben ook de huisartsen een rol gespeeld bij het selecteren van patiënten. Zo kunnen zij patiënten hebben geselecteerd die zeer betrokken zijn geweest bij het overdrachtsproces en waarbij de rechtspositie werd gerespecteerd. Aan de andere kant kunnen huisartsen juist die patiënten hebben geselecteerd die zelf geen belang stellen in enige betrokkenheid bij het overdrachtsproces en zich overleveren aan de hulp van artsen en verpleegkundigen. In dit onderzoek lijken - gezien de gevarieerde beschrijvingen - beide selecties te hebben plaatsgevonden. 
ad 68

Het tijdstip van het interview kan bepalend zijn voor de loop van het gesprek (wervorming door "geschiedenis"). Zo bleek het niet of nauwelijks mogelijk om met de respondenten te spreken over het overdrachtsproces van een bepaalde patiènt. Alleen met de patient kon over zijn ervaringen worden gesproken, maar zijn verhaal kon niet worden aangevuld door andere betrokkenen. Toch konden ook patiënten zich bepaalde gebeurtenissen niet meer herinneren. De reden hiervoor zou kunnen zijn dat bepaalde informatie en het toestemmingsvereiste deze patienten niet zo interesseerden. Hierop wordt in de volgende paragraaf nader ingegaan.

Met de huisartsen kon niet op het specifieke overdrachtsproces worden ingegaan omdat zij - ondanks dringend verzoek van de onderzoekster - pas na het interview een patiënt benaderden met het verzoek om aan het onderzoek mee te doen. Tijdens het interview was derhalwe nog niet bekend welke patiënt met het onderzoek mee zou doen. Wijk- en ziekenhuiswerpleegkundigen konden zich net zo $\mathrm{min}$ als specialisten herinneren op welke wijze de zorg van een bepaalde patiënt was overgedragen. Met name konden zij, ondanks het feit dat de overdracht niet langer dan drie maanden geleden had plaats gevonden, geen antwoord meer geven op specifieke vragen omtrent de informatie die zij de patiënt hadden verstrekt, of en zo ja op welke wijze professionele informatie was uitgewisseld en of en waarover de patiënt hen vragen had gesteld. Aangezien deze informatie ook niet schriftelijk was vastgelegd of het dossier net onvindbaar was, moest veelal genoegen worden genomen met een algemeen verhaal van de respondent over het overdrachtsproces.

Het idee om door middel van het "sterretje" (figuur 4.1) met behulp van interviews een valide beeld te krijgen van het overdrachtsproces van een bepaalde patiënt viel dus tegen. Het "sterretje" gaf echter wel een zekere aanvulling op het verhaal van de respondenten. Ik bezocht de lokaties waar de patiënt ook geweest was en sprak met hulpverleners die met elkaar en met de patiënt gesproken hadden. Kortom, de informatie verkregen in de twee interview-ronden rond bepaalde topics met betrokkenen uit een aantal casus leverde waardevolle informatie op.

\subsubsection{Resultaten}

In deze paragraaf zal achtereenvolgens worden ingegaan op het recht op informatie, het toestemmingsvereiste, het recht op wrije keuze, het recht op informationele privacy en het recht op inzage, zoals die in de bestudeerde casus naar voren kwamen. Bij het beschrijven van de resultaten zullen bij elk recht de opvattingen en ervaringen van achtereenvolgens patiënten, artsen en verpleegkundigen worden belicht. Hierbij wordt soms aangegeven dat het een opvatting is van én patiënt of beroepsbeoefenaar. Soms wordt aangegeven dat het de mening/werkwijze van enkele of verschillende personen is. Voor deze beschrijving is gekozen on aan te geven dat meer personen eenzelfde opmerking maakten, zonder hiermee te willen aangeven dat dergelijke uitspraken van groter belang zouden zijn. De ordening binnen elke paragraaf is gebaseerd op het in het vorige hoofdstuk beschreven juridische kader. 


\subsubsection{Het recht op informatie}

Bij overdracht van zorg vindt informatieverstrekking plaats bij de verwijzing van de patiënt naar de specialist/het ziekenhuis (informed referral) en bij ontslag uit het ziekenhuis (informed discharge). Bij deze twee overdrachtsmomenten wordt in deze subparagraaf nagegaan waar de informatie betrekking op heeft, door wie deze wordt verstrekt. wanneer wel en wanneer geen informatie wordt verstrekt en op welke wijze dit gebeurt.

\section{Informed referral}

\section{* Wie verstrekt de informatie?}

In de interviews met patiënten wordt niet specifiek ingegaan op de vraag wie bij de verwijzing informatie verstrekt. Het antwoord ligt namelijk erg voor de hand: omdat de meeste patiënten door de huisarts naar het ziekenhuis worden verwezen is hij degene die de patiënt informeert. Bij acute opnames is in feite niet van verwijzing sprake.

In de interviews met huisartsen wordt aangegeven wie de informatie verstrekt. Eén huisarts zegt hierover het volgende:

"Ja, een specialist neemt het over, maar het blifft onze patiënt, dus ik vind het onze taak om de patiënt voor verwijzing te informeren over de richting die het mogelijk op zal gaan. De specialist kan informatie geven over de definitieve diagnose."

Een andere huisarts vertelt zijn patiënt bij verwijzing dat hij hem in het ziekenhuis altijd op mag bellen als hij iets te bespreken of te vragen heeft. Dit raadt hij de patiënt aan omdat "het niet haalbaar is om elke patiënt achterna te blijven lopen."

Verpleegkundigen geven aan dat de arts de medische informatie omtrent de diagnose aan de patiënt moet mededelen. Toch komen verpleegkundigen in de interviews zelf steeds terug op het door verpleegkundigen verstrekken van medischtechnische informatie. Eén wijkverpleegkundige stelt dat de huisarts of de specialist informatie over medische zaken moet geven, terwijl zij de verpleegtechnische zaken aan de patiënt uitlegt.

\section{* Waarover gaat de informatie?}

Uit de interviews komt naar woren dat de informatie bij de verwijzing van een patiënt betrekking kan hebben op de reden van de verwijzing, de voorlopige diagnose, de keuzemogelijkheden van de patiënt en de informatie-uitwisseling tussen beroepsbeofenaren.

In de interviews met de patiënten komen deze aspekten het minst terug. Patiënten geven aan te begrijpen waarom de huisarts hen naar het ziekenhuis verwijst. Zo vertelt één patiënt:

"Hij zei: "Het is een liesbreuk, ik moet u naar het ziekenhuis sturen." 
Bij een acute verwijzing is voor informatieverstrekking weinig ruimte. Van een niet-acute verwijzing weet één patięnt zich het volgende nog te herinneren.

"Ik kwam bij hem in juni, ik zeg dokter ik ben schor en ik ben niet verkouden.... toen gaf hij me 5 pilletjes mee en als ze op zijn kom je maar terug en toen ik na 5 dagen terug kwam zat hij al te schrijven, hij zij: "Ga maar naar de dokter aan de overkant", daar woonde die keelarts."

Dat een patiẻnt bij de verwijzing niet altijd wordt geïnformeerd over de ernst van de klacht bewijst het volgende citaat:

"Voor ik werd verwezen had ik geen flauw idee van hoe ernstig het was, dat hoorde ik pas toen de operatie voorbij was."

Een andere patiënte geeft aan hoe haar huisarts de keuze voor een bepaald ziekenhuis motiveert.

"De dokter zei dat ze dat ziekenhuis het best geschikt vond voor mij en dan geloof ik haar ook. Ze lichtte toe dat het een reuma ziekenhuis was en ik heb reuma."

Patiënten weten over het algemeen niet meer of informatie-uitwisseling tussen huisarts en specialist heeft plaatsgevonden. Over de inhoud van de brief worden ze niet geînformeerd. De brief wordt over het algemeen niet gelezen omdat er moeilijke woorden instaan, omdat het hen niet interesseert of omdat verondersteld wordt dat ze de brief niet mogen lezen. Eén patiënte geeft treffend aan wat zij van dèze brief vindt.

P(atiënt): "De verwijsbrief heb ik niet gelezen, ik kreeg hem mee en gaf hem aan de specialist, hij was gewoon dichtgevouwen."

I(nterviewer): "Maar u hoeft hem niet te lezen?"

$P$ : "Nee, omdat er allemaal van die moeilijke woorden instaan, dat begrijp ik toch niet."

Eén patiënt geeft te kennen niets over de professionele informatie-uitwisseling te weten.

I: "En weet $u$ of er bepaalde informatie van de huisarts naar de spe. clalist is gegaan?"

$P$ : "Daar weet ik niks van."

I: "Zou w dat willen weten"

P. "Dat hoef ik niet te weten. Er moet een beetje afstand zijn tussen

de patiënt en de dokter. Ik hoef dat allemaal niet te weten, waarom en hoe. Sommige mensen moeten het naadje van de kous weten, maar ik vertrouw op hun. En mijn vrouw ook. Als je nou alles vraagt aan de dokter ... ten eerste begrijpen wij dat niet zo gauw, dan zou hij het al gauw een paar keer moeten vertellen, dat het tot me doordringt, he? Als hij het éen keer vertelt, dan begrijp ik het niet."

In de interviews met de huisartsen komen de verschillende aspekten veel uitvoeriger aan de orde. Eén huisarts geeft als volgt weer hoe hij de reden van de verwijzing aan de patiënt toelicht: 
"Ik zeg: "Ik stuur $u$ toch even door naar dokter $x, y$ of $z$." Vermoedens geef ik zijdelings een beetje aan. I $k$ ga niet zeggen dat er een kans van $1 \%$ is dat het kanker zou kunnen zijn, maar we moeten uitkijken, geen risico nemen of zo en wat de specialist mogelijk gaat doen: in uw maag kijken, scan maken, bloedonderzoek."

Een andere huisarts uit zijn vermoedens pas als de patiënt niet echt verwezen wil worden.

"Als ik zeker weet, of bijna zeker weet dat het kanker is dan zeg ik:

"Nu moet je naar het ziekenhuis." Als de patiënt niet echt wil, dan probeer ik hem duidelijk te maken waarom ik het wel nodig wind. Dan zou ik bij vermoeden van kanker kunnen zeggen: "Nou, het zou wel eens kwaadaardig zijn en dat moeten we voor zijn."

Dat een huisarts de patiënt toch kan informeren zonder in eerste instantie op de diagnose in te gaan bewijst het volgende citaat.

"Ik denk dat het niet altijd zinnig is om de hele differentiaaldiagnose met de patiênt te bespreken. Ik verwijs niet zonder uitleg naar bijvoorbeeld een longarts, maar zeg: "U hebt bloed opgehoest, dat kan veel oorzaken hebben en dat moet verder uitgezocht worden." Als mensen zelf zich in iets verdiept hebben, wat meer opleiding hebben, dan kun je op iets nader ingaan, maar dat geven ze zelf aan."

Uit de interviews zou men voorzichtig kunnen concluderen dat volgens de huisartsen de meeste patiënten bij de verwijzing niet precies weten welke diagnose gesteld is. Meestal weten ze wel met welk denkbeeld de huisarts hen gestuurd heeft en wat ze globaal in het ziekenhuis kunnen verwachten.

Blijkens de interviews met de huisartsen besteden deze weinig aandacht aan de informatie die voor de patiënt van belang is voor het maken van keuzes. Eén huisarts geeft aan dat hij "de patiënt niet specifiek informeert over een keuzemogelijkheid, maar dat hij adviseert als de keuze voor de patiënt een probleem is."

Een andere huisarts stelt dat bij een verwijzing naar het ziekenhuis kennis over eventuele wachttijden van belang is. Hij voegt daar echter aan toe dat hij de patiënt hier niet specifiek over informeert ondat deze het zelf wel merkt als hij het ziekenhuis belt voor een afspraak.

Huisartsen geven in de interviews aan dat patiënten op de hoogte zijn van de schriftelijke professionele informatie-uitwisseling tussen huisarts en specialist. Soms omdat de brief wordt geschreven waar de patiënt bij zit, soms omdat de huisarts de brief hardop voorleest en daarbij de latijnse termen vertaalt. De huisarts vertelt echter, zoals hieronder blijkt, niet altijd alles wat hij opschrijft.

"Als de patiënt ruim gebruiker van alcohol of verdovende middelen is dan vermeld $i k$ dat wel als het te maken kan hebben met de aandoening, maar ik praat er niet over met de patiënt of hij het goed vindt. Waarom niet? Het hoort bij het verhaal." 
Eén patiënte blijkt niet expliciet op de hoogte te worden gesteld van de mondelinge informatie-uitwisselling:

"Tegen de patiënt zeg ik: "Nou, ik bel nog even." Ja, eigenlijk weet de patient het min of meer wel."

Tenslotte verzoekt een aantal huisartsen hun patiënten om bij thuiskomst direct op te bellen. Eên huisarts bespreekt voor verwijzing met zijn patiènt dat deze de zorg goed in de gaten moet houden omdat er soms dingen gebeuren waar de huisarts hem niet voor heeft doorverwezen en er bovendien vergissingen voor kunnen komen.

Enkele wijkwerpleegkundigen geven aan de patiënt te informeren omtrent het contact met ziekenhuisverpleegkundigen. Eén wijkverpleegkundige geeft hiervoor als reden dat het de patiënt op zijn gemak zou stellen als deze zou weten dat gegevens werden doorgegeven. Eén wijkverpleegkundige vindt dat de patiënt alles zou moeten weten van wat ze opschrijft.

\section{* Wanneer wordt wel en wanneer wordt geen informatie verstrekt?}

In de interviews met de patiënten wordt geen aandacht geschonken aan het feit of artsen wel of geen informatie aan de patiënt verstrekken bij de verwijzing.

Huisartsen daarentegen gaan heel bewust met het wel of geen informatie verstrekken om. Eén huisarts zegt hierover:

"Als ik een patiënt bij de verwijzing absoluut iets niet vertel heeft dat te maken met de individuele patiënt. De ene patiënt wil het wel graag weten, de andere patiënt niet."

I: "En hoe weet $u$ of hij het wel of niet wil" weten?"

A: "Dat moet je peilen, tja.. als ze niet doorvragen en als het afgewezen wordt, nou dan liever niet."

Ook andere huisartsen schatten voordat zij informatie verstrekken in met wat voor patiënt zij te maken hebben en "hoe de patiënt vraagt, doorvraagt en wat voor discussie erop steekt."

Eén huisarts stelt dat hij de patiënt altijd informeert maar dat de informatie bij de patiênt "soms niet wil overkomen." Een andere huisarts stelt:

"Veel mensen ken je en bij sommigen weet je dat het geen zin heeft om ergens heel gedetailleerd over te praten of voorlichting te geven."

Eén huisarts beschrijft de patiënten die hij niet informeert als dusdanig oude patiënten, dat zij de informatie niet meer begrijpen.

Tenslotte gaan enkele huisartsen in de interviews in op het inwilligen van de wens van de familie om de patiënt niet te informeren. De meeste willigen deze wens niet in en proberen aan de familie uit te leggen dat niet informeren slecht is voor onder andere de communicatie tussen gezinsleden. Eén huisarts zegt hier over.

"Ik hoor de wens van de familie om de patiënt niet te informeren aan, maar ik denk dat mijn oordeel over de patiënt uiteindelijk bepaalt 
hoeveel er overkomt. Ik laat mijn oordeel afhangen wan de wens van de patiënt om wel of niet geinformeerd te willen worden. Ik vraag de patiënt ook wat hij nou eigenlijk zou willen weten."

Eén huisarts geeft aan dat tijdgebrek of een volle wachtkamer ook bepalend zijn voor het niet of niet volledig verstrekken van informatie. De informatie die de patiënt niet wordt verstrekt, maar die voor de specialist wel van belang is wordt door één huisarts in de verwijsbrief opgeschreven en deze wordt per post opgestuurd. De patiënt wordt in bepaalde situaties well geinformeerd. Zo stelt eén huisarts:

"Als ik de indruk krijg dat iemand zijn eigen situatie niet goed inschat en ik toch vind dat iets moet óverkomen dan kan het zo zijn dat ik toch probeer dit over te brengen."

Wijkverpleegkundigen gaan in de interviews niet in op de vraag wanneer zij wel of geen informatie aan de patiënt verstrekken. De reden hiervoor is dat zij vaak niet op de hoogte zijn van de verwijzing van de patiënt naar het ziekenhuis.

\section{* Hoe wordt de informatie verstrekt?}

Patiënten geven in de interviews niet aan op welke wijze de informatie wordt verstrekt. Evenmin als de inhoud van de informatie konden de patiënten zich de wijze van informeren herinneren.

De huisartsen belichten wel dit aspect van de informatieverstrekking. Hierbij galat een aantal artsen in op de dosering van de informatie. Eén huisarts zegt hierover:

"Als ik merk dat iemand van slag is, helemaal geblokkeerd, dan vraag

$i k$ of ze nog een keertje terugkomen als het allemaal wat gekalmeerd

is. Soms heb je wel eens een langer proces nodig om het allemaal uit

te leggen, soms lukt het in een keer."

Dezelfde huisarts vervolgt even later:

"Ik denk dat mensen heel weinig voor informatie opkomen, ze zijn misschien ook wel een beetje bang om dingen te horen die ze eigenlijk niet willen horen. Als arts moet je hiermee rekening houden door geen informatie te verstrekken als de patiënt niet wil weten dat er iets aan de hand is. Je moet informatie afstemmen op vragen."

Een andere huisarts haalt het probleem aan van informatieverstrekking aan buitenlanders.

"Bij Marokkaanse of Turkse mensen zit je met een taalbarrière en moet je proberen zoveel informatie te geven dat ze ermee wit te voeten kunnen zonder dat ze in angst zitten."

Tenslotte geeft én huisarts aan hoe hij omgaat met de vraag van de patiènt of hij dood gaat. Hij beschouwt dit als hele intense contacten.

"Als iemand vraagt ga ik dood dan zeg ik: je gaat zeker dood, ik kan alleen niet zeggen wanneer." 
Wijkverpleegkundigen gaan niet in op de wijze waarop zij informatie aan de patiènt verstrekken bij de verwijzing van de patiënt naar het ziekenhuis. De reden hiervoor is dat zij niet weten dat de patiënt wordt opgenomen.

\section{Informed discharge}

* Wie verstrekt de informatie?

Volgens de patiënten wordt de informatie bij ontslag verstrekt door éến of verschillende specialisten.

I: "Was het altijd dezelfde arts die u informatie gaf?"

P: "Nee, ik heb geen zelfde arts gehad in het ziekenhuis, wel een maatschap. Het was wel duidelijk wat ze vertelden alleen een beetje verwarrend."

De patiènten geven aan in het ziekenhuis door de specialist geïnformeerd te worden omtrent de diagnose en niet pas thuis door de huisarts.

De huisarts speelt geen rol bij de informatieverstrekking in het ziekenhuis. Volgens eén patiênt kwamen alle nieuwe berichten van de specialist. Een andere patiënt geeft aan dat de specialist de informatie bij ontslag verstrekt.

"De huisarts gaf geen informatie over hoe het met me ging en wanneer ik naar huis kon, maar zei wel dat ik als ik naar huis toekwam ik het hem dat moest laten weten."

Verder kunnen patiënten zich alleen nog herinneren dat de hoofdverpleegkundige informatie gaf over nazorgmogelijkheden.

De specialisten geven in de interviews uitsluitend aan wie de diagnose aan de patiënt verstrekt; in principe de specialist zelf. Eén specialist zegt hierover het volgende:

"Over het algemeen zijn onze patiënten voldoende geïnformeerd bij hun ontslag. Er zijn best wel eens wat vragen, maar daar heb je dan de huisarts weer voor, want je kan niet alles in een keer opnemen, of je vergeet wel eens wat of er komt een vraag later bij je op."

Volgens een andere specialist wordt soms in overleg met de huisarts besloten of de huisarts de patiënt informeert over zijn diagnose. De reden hiervoor is dat hij de patiënt beter kent. Eén huisarts constateert dat hij het idee heeft dat patiënten soms bij hem komen om uitleg te krijgen over wat een specialist gedaan heeft. Eén specialist stelt dat eigenlijk niemand het ziekenhuis verlaat zonder dat hij weet waar hij aan toe is. Het gebeurt volgens hem niet vaak dat een huisarts de informatie verstrekt in plaats van de specialist. Hij voegt hieraan toe:

"Bij mensen die het absoluut niet willen weten vertel je de huisarts waarom je de patiënt niet hebt geïformeerd en dan kan het gebeuren dat de huisarts het bijvoorbeeld drie weken later wel vertelt. Of dat de familie het hem verteld heeft. Dat zijn vervelende dingen." 
Volgens één specialist is de patiënt op de hoogte van eventuele contacten tussen specialist en huisarts. Hij zegt hierover:

"Het is in eerste instantie de specialist die de patiënt vertelt wat er besproken gaat worden met andere dokters."

Eén wijkverpleegkundige geeft aan niet zelf informatie te vertrekken aan de patiënt, maar de patiënt te helpen bij het inwinnen van informatie:

"Ik help de patiënt met het formuleren van vragen door met de patiënt over zijn problemen te praten. Ook geef ik hem het advies niet bij de specialist weg te gaan voordat hij antwoord heeft gekregen."

Eén wijkverpleegkundige vindt dat er ook van de wijkverpleegkundige een eerlijk antwoord moet komen. Een andere wijkwerpleegkundige vindt daarentegen dat het niet haar taak is om de patiënt na ontslag te vertellen dat hij kanker heeft.

Eén ziekenhuisverpleegkundige stelt dat zij de gemoedstoestand van de patiënt het beste kan inschatten. Ze probeert de vragen van de patiënt zo te beantwoorden dat ze geen ontkennende antwoorden hoeft te geven, waarna zij de vragen doorgeeft aan de arts. Ook een andere ziekenhuisverpleegkundige geeft aan dat ze vermijdt om informatie zelf te geven, maar dat ze de arts soms stimuleert zodat deze op een bepaald moment de patiënt meer informatie verstrekt.

\section{* Waarover gaat de informatie?}

Patiënten gaan in de interviews nauwelijks in op de unhoud van de informatie bij ontslag uit het ziekenhuis. Eén patiënte geeft treffend aan welke informatie zij kreeg van de specialist.

"De specialist zegt: "Wij maken wel uit of je naar huis gaat, je gaat niet naar huis als je niet voldoende hulp hebt."

Dat patiènten niet altijd vragen stellen terwijl ze die wel hebben, bewijst het volgende illustratieve fragment:

$P$ : "Ik heb ook niet gevraagd wat het eigenlijk was, daar heb ik wel recht op."

I: "Hoe komt het dat u dat niet gevraagd hebt?"

$P$ : "Het kwam niet bij me op, ik kwam weer bij, dat was voor mij voldoende."

Ook een andere patiënt toont een zekere berusting:

I: "U had meer vragen dan u aan antwoorden kreeg."

$P$ : "Ja, ik heb vaak geen informatie gehad."

I: "Vindt $u$ dat $u$ recht had om het te weten?"

$P$ : "Ach, toen wel, maar nu niet meer."

Informatie met betrekking tot het inschakelen van een wijkverpleegkundige vindt én patiënt niet nodig omdat bij hem thuis al een wijkverpleegkundige kwam voor zijn manisch depressieve vrouw. Eén patiënte denkt dat de huisarts de wijkzorg heeft geregeld, terwijl een andere patiënt verondersteld dat de zaallarts dit voor hem geregeld heeft. Eén patiënt ziet wijkzorg als noodzaak. Tenslotte geeft één 
patient aan niet te weten over de mogelijkheden van wijkzorg geïnformeerd te $\mathrm{zijn}$

Ten amzien van de professionele informatie-uitwisseling geven twee patiënten aan dat ze niet weten of dit heeft plaats gevonden. Eén patiënt verondersteld dat geen informatie wordt uitgewisseld en een andere patiënt zegt hierover:

"Ik kreeg een brief mee yoor de huisarts, maar die heb ik dicht gelaten. Je mag dit soort brieven niet openmaken."

Specialisten hebben meestal een gesprek met de patiënten voordat deze naar huis gaan. Hierin wordt gepraat over wat er nou precies gebeurd is en waar ze zich aan moeten houden als ze naar huis gaan om te voorkomen dat het probleem zich gaat herhalen. Eén specialist houdt bij ontslag een aantal zaken nauwlettend in de gaten, doch verstrekt bepaalde informatie niet zelf.

$S$ : "Je moet ze op de hoogte brengen van waar ze aan toe zijn, wat er in het ziekenhuis is gebeurd en daarna waar ze contact mee moeten ophemen en warvoor ze zijn verzekerd"

1: "Doet $u$ die laatste twee dingen zelf of laat $u$ dat over aan andere mensen?"

S: "Over het algemeen stel ik me wel op de hoogte of die informatie wordt versitrekt. Ik kan me er zelf niet mee bemoeien, maar ik heb een goede indruk of daaraan gewerkt wordt."

Volgens specialisten wordt de patiënt geïnformeerd over het feit dat gegevens naar de huisarts worden gestuurd. Eén specialist antwoordt op de vraag hoe hij de patiënt hierover informeert echter:

"Het is me nog nooit overkomen dat de patiënt tegen me zei van dat mag je de huisarts niet vertellen."

Volgens dezelfde specialist komt dit omgekeerd wel voor, alloewel de meeste huisartsen open enveloppes meegeven om dat soort problemen te voorkomen. Deze informatie heeft dan vooral betrekking op sociale problemen.

Eén specialist veronderstelt dat de patiènt de informatie die hij naar de huisarts stuurt leest en zegt hierover het volgende:

"Als de patiënt de brief wil lezen vraagt hij het maar aan de huisarts. Hiervoor zou de huisarts niel meer apart contact met de specialist hoeven op le nemen. Als hij de patient kent en hij kan inschatten of de brief gelezen kan worden heb ik daar geen problemen mee."

Ziekenhuisverpleegkundigen geven aan dat zij de patiënt niet expliciet informeren over de informatie-uitwisseling. Wel wordt de patiënt gevraagd of hij accoord gaat met het inschakelen van wijkverpleegkundige zorg.

Eén wijkverpleegkundige gat ervan uit dat de patięnt weet dat zij een overdrachtformulier krijgt, maar informeert de patiẻnt hierover niet. Ze kan zich echter niet herinneren iemand ontmoet te hebben die niet op de hoogte was. 
* Wanneer wordt wel en wanneer wordt geen informatie verstrekt?

Patiënten zeggen in de interviews weinig over het wel of niet verstrekken van informatie door specialisten. Eén patiënte antwoordt op de vraag of ze nooit meer wilde weten dan de dokter haar vertelde:

"Nee, dan vraag ik het, ik ben misschien zo brutal om het te vragen."

Een andere patiënte vindt haar houding ten aanzien van de informatieverstrekking bellangrijk. Zij zegt hierover:

"Ik kan u zeggen dat ze me ontzettend goed antwoorden op wat ik vraag. Ik vraag erg veel. Als ik iets vraag dan laten ze me het zien en dan leggen ze het uit of ze vragen wat ik er zelf van vind. Maar ja, $i k$ werk aan mijn kant ook wel mee."

I: "Hoe?"

P: "Door positief tegenover alles te staan, niet zo van jakkes nog aan toen nou moeten ze dat nog met me doen en dat nog....ik accepteer het graag."

Kenmerkend voor het verwachtingspatroon van de patiënt ten opzichte van de informatieverstrekking is de volgende passage:

I: "Hebt $u$ wel eens tegen de arts gezegd dat $u$ echt altijd de waarheid wilde horen, ook als de diagnose niet gunstig is?"

P: "Nee, nooit."

I: "U gaat ervan uit dat de specialist alles tegen $u$ vertelt?"

$P$ : "Ja, ik ga ervan wit, ze weten wat ik wil en dan hoor ik het."

De specialisten geven in de interviews duidelijk grenzen aan in de informatieverstrekking over de diagnose aan de patiënt. Ook de specialist kijkt bij bijwoorbeeld de diagnose kanker eerst met wat voor soort patiënt hij te maken heeft en wat de leeftijd is. Volgens én specialist zeggen patiënten nooit dat ze verder niet meer geïnformeerd willen worden, maar ze hanteren het mechanisme wel door gewoon niets meer te horen. Een andere specialist heeft wel eens het verzoek gehad van een patiënt om "hem niet te informeren als de uitslag van het onderzoek kwaadaardig was." De specialist respecteerde dit verzoek, maar omdat de patiënt nooit de uitslag had gekregen was hij volgens de specialist wel op de hoogte, alleen wilde hij de uitslag niet rechtstreeks horen.

Eén specialist heeft te maken met verzoeken van de familie om de patiënt niet te informeren, al komt dat volgens een specialist zelden voor. Is er sprake van een dergelijk verzoek dan overlegt een specialist met de huisarts hoe en wie de informatie zal geven. Een andere specialist geeft aan moeite te hebben met het negeren van het verzoek van de familie en stelt:

"Het gebeurt regelmatig dat je een patiënt op verzoek van de famille niet inlicht. Als je zo iemand dan toch inlicht en hij wordt verdrietig moet je voorzichtig zijn dat het niet met de familie botst."

Eén specialist wacht met het verstrekken van informatie tot de patiënt een vraag stelt omdat hij veronderstelt dat de patiënt niet alle informatie meer kan verwerken. Bovendien stelt hij dat je "iets op verschillende manieren kan zeggen." 
Ziekenhuisverpleegkundigen gaan nauwelijks in op het wel of geen informatie verstrekken. Eên ziekenhuisverpleegkundige stelt:

"Ik vind dat een patiënt altijd alles mag weten, maar soms vind ik maar dat je even moet zwijgen en dat kan over van alles zijn, bijvoorbeeld over de opname van een patiënt in een verpleeghuis, omdat de patiënt anders scènes gaat trappen."

Volgens één ziekenhuisverpleegkundige stellen mensen met vage klachten die meestal uit de kwaadaardige hoek komen de meeste vragen. Angstige patiënten zouden minder vragen stellen. Volgens haar was dit niet leeftijdsafhankelijk.

\section{* Op welke wijze wordt de informatie verstrekt?}

Patiënten kunnen zich in de interviews delen van het ontslaggesprek herinneren. Zo vertelt één patiënt:

"De arts zei:" "Het gaat wel weer, he?"...(ja als hij me zo hoort..) en de andere dag mocht ik naar huis. Ik had al een week eerder naar huis gekund, maar ze wisten dat ik toch alleen thuis was en toen hebben ze me maar gehouden."

Informatie over de diagnose werd volgens een patiënt niet bij ontslag verteld maar tijdens het poliklliniekbezoek. Opvallend daarbij vond éen patiënt dat de arts het woord kanker niet durfde te noemen. Hij vertelt hier als volgt over:

"Toen de hij (de arts) zei dat het bestraald moest worden zei ik:" "Het is kanker", gauw klaar. Ze zeggen nu nog niet het is kanker."

Volgens specialisten vindt de dag voor het ontslag het ontslaggesprek plaats; onder vier ogen of met de partner erbij. Eén specialist overlegt eerst met de familie of hij de patiënt gaat informeren of dat de familie het liever zelf doet. Op zich vindt hij dat de informatie niet door de familie moet worden verstrekt en meestal doet hij het samen met de familie. Eên specialist merkt hierover op dat hij bij demente patiënten eerst de farnilie informeert omdat "zij er verder mee moeten."

Eén specialist constateert dat hij de patiënt in de eerste fase meerdere keren iets moet vertellen voordat deze begrijpt wat er gezegd wordt. Een andere specialist zegt hierover:

"Ik denk dat niemand het ziekenhuis verlaat zonder dat hij op de hoogte is, soms zijn dingen onduidelijk, maar dat kan ook wel komen door het feit dat we het hem dan niet genoeg verteld hebben, dat het verhal niet goed begrepen is."

Tenslotte merkt én specialist het volgende op:

"Je kunt een patiënt wel volstouwen met informatie, maar de kunst is om iemand het gevoel te geven dat hij begrijpt waar het om gaat en dat hij zich tevreden voelt."

Eén ziekenhuisverpleegkundige geeft aan niet te doen alsof haar neus bloedt als de patiënt vragen stelt, maar eerlijk te antwoorden. 


\subsubsection{Het toestemmingsvereiste}

In deze paragraaf wordt ingegaan op het toestemmingsvereiste. Bij de beschrijwing zal achtereenvolgens worden belicht waarvoor toestemming wordt gegeven bij overdracht van zorg wanneer volgens de respondenten wel en wanneer geen toestemming wordt vereist en op welke wijze de toestemming van de patiënt wordt verkregen. Hierbij wordt geen onderscheid gemaakt in het toestemmingsvereiste voor opname en na ontslag uit het ziekenhuis.

\section{* Waar wordt toestemming voor gegeven?}

Patiënten kunnen in de interviews niet aangeven warvoor hun toestemming nodig is in het overdrachtsproces. Op de vraag of aan hen voor de verwijzing, het ontslag en voor de professionele informatie-uitwisseling toestemming is gevraagd, geven de meeste aan dat dit niet is gebeurd. Op het toestemmingsvereiste voor de verwijzing en het ontslag gaan patiënten verder niet door. Over het toestemmingsvereiste voor de gegevensoverdracht wordt meer gezegd. Eén patiënt beschouwt de informatie die de huisarts aan de specialist verstrekt als "zakelijke dinges die natuurlijk aan de specialist mag worden doorgegeven."

Een andere patiënt geeft als antwoord op de vraag of ze haar huisarts zou willen verzoeken om bepaalde informatie over haar niet aan de specialist door te geven: "Oh, nee, misschien de jongere generatie, die is veel mondiger, maar ja, je bent het gewend van vroeger. Vroeger werd het dichtgeplakt en een zegel werd erop gezet, dat kon je vroeger ook niet open maken."

Naast de toestemming voor de gegevensoverdracht denkt één patiënte dat zij bij ontslag uit het ziekenhuis geen wijkverpleging had kunnen weigeren want:

"Ik ben geen zuster en zij hebben ervoor geleerd dus dat kan je niet weigeren."

Huisartsen vragen de patiënt in principe geen toestemming voor de verwijzing. Eén huisarts geeft als reden dat de meeste mensen die niet verwezen willen worden dat gewoon zeggen. Tevens komt het volgens hem zelden voor dat mensen dit niet zeggen en toch niet gaan (uitgezonderd mensen die naar RIAGG verwezen zijn). Een andere huisarts vindt dat de toestemming van de patiënt noodzakelijk is voor de inschakeling van de wijkverpleging, maar ook voor de inschakeling van de familie. De patiênt moet steeds bepalen of het mag. Specialisten vragen voor het ontslag niet expliciet de toestemming van de patiënt. Zo stelt één specialist:

"Meestal wordt met de patiënt besproken dat ze de volgende dag naar huis kunnen. Als er dan redenen zijn dat dat echt niet kan dan proberen wij er rekening mee te houden, maar dat is erg moeilijk. Mensen die gewoon nog een paar daagjes willen blijven om op verhaal te komen, terwijl ze eigenlijk niks mankeren, dat kan niet meer tegenwoordig."

Opmerkelijk is dat in de interviews met artsen zowel huisartsen als specialisten denken aan het toestemmingsvereiste voor het verrichten van een bepaald onderzoek of behandeling. Eén huisarts geeft als voorbeeld de toestemming van een Jehovagetuige voor een bloedtransfusie. Enkele specialisten zeggen dat zij rekening 
houden thet de wens van de patiënt om ontslagen te worden. Eén specialist geeft aan dat hij een keer de wens van de patiënt om ontslagen te worden, niet heeft ingewilligd. Het betrof de wens van een moeder van kleine kinderen. Hij wilde haar pas ontslaan nadat kinderopvang was geregeld. Hij voegde hieraan toe dat je patiênten wel moet laten inzien waarom ze zijn opgenomen. Dat het toestemmingsvereiste ook een rol kan spelen bij de overdracht van zorg komt in de interviews nauwelijks naar voren.

Voor de schriftelijke informatie-uitwisseling vraagt één huisarts geen expliciete toestemming. Hierbij merkt hij op:

"Als het gaat om informatie dan geef ik die gewoon door zonder daar verder $e h, j a \ldots . .1 k$ denk, dingen waar niemand wat mee te maken heeft die vermeld ik niet, ik geef to the point informatie over hetgeen waar de patiënt voor komt."

Enkele huisartsen stellen dat zij het onwerkbaar zouden vinden alls patiënten steeds toestermming zouden moeten geven voor de informatie-overdracht. Eén huisarts merkt op dat patiënten nogal nijdig worden als zij merken dat hij onvoldoende op de hoogte is omdat hij de ontslagbrief nog niet heeft ontvangen.

Eén huisarts heeft wel eens informatie op verzoek van een patiënt achtergehouden omdat patiënten voor hem "toch nog wel een beetje heilig zijn." Een andere huisarts schrijft in de verwijsbrief niet op wat de patiënt hem in vertrouwen heeft verteld. Als voorbeeld noemt hij een vrouw die in de avonduren wat bijverdient in de prostitutie en een bankovervaller die hij naar de specialist verwijst.

Eén specialist stelt dat hij de patiënt vertelt dat hij de huisarts een brief stuurt en dat het hem nooit was overkomen dat de patiënt had gevraagd bepaalde informatie niet door te geven. Een andere specialist geeft aan dat de schriftelijke informatieoverdracht automatisch plaatsvindt, maar ook hij vertelt de patiënt dat hij zijn bevindingen naar de huisarts op zal sturen.

Wijkverpleegkundige gaan in hun interviews in zeer beperkte mate in op de vraag waar bij overdracht van zorg toestemming voor wordt gegeven. Eén wijkverpleegkundige veronderstelt dat ziekenhuisverpleegkundigen de patiënt toestemming vragen om wijkverpleegkundige zorg aan te vragen. Bovendien denkt ze dat er een overdracht wordt geschreven naar de huisarts als de patiënt geen wijkverpleegkundige zorg nodig heeft. Eén wijkverpleegkundige zal niet aandringen als de familie in eerste instantie vindt dat de patiênt geen wijkverpleegkundige zorg nodig heeft.

Voor het verstrekken van informatie aan de ziekenhuisverpleegkundige vraagt én wijkverpleegkundige geen toestemming aan de patiënt omdat deze informatie-uitwisseling beschouwd wordt als een gebruikelijke gang van zaken. Volgens haar is de patiënt wel op de hoogte van de berichtgeving omdat ze de overdracht in het bijzijn van de patiënt schrijft of naderhand aan de patiënt vertelt dat ze de ziekenhuisverpleegkundige informatie heeft gestuurd. 
Tussen wijk- en ziekenhuisverpleegkundigen vindt informatie-overdracht plaats, ook zonder expliciete toestemming van de patiënt, zelfs als de patiẻnt het niet met de uitwisseling eens is. Eén wijkverpleegkundige zegt hierover:

"Als ik het in het belang van de mens acht, dan denk ik dat ik eerst zou averleggen met het team en dan zeggen van nou, wel of niet. Dat moet je per situatie bekijken, of het relevant is."

Een andere wijkverpleegkundige geeft als volgt aan waarom zij informatie aan een ziekenhuisverpleegkundige doorgeeft:

$V$ : "In principe schriff ik op wat wij voor zorg geven in de thuissitua-

tie en dat geef ik mee naar het ziekenhuis, eventueel met een toelichting, bijwoorbeeld mevrouw kan moeilijk bij haar tenen, wilt $u$ daar extra opletten. Van die kleine dingen."

I: "Zou een patiënt dat zelf niet kunnen zeggen?"

$V$ : "Ja, maar vaak durven ze dat toch niet of vinden ze het een beetje vervelend om die kleine dingetjes te vragen."

Eén wijkverpleegkundige vindt dat ze nooit iets zonder de toestemming van de patiënt kan doen. $\mathrm{Zij}$ zegt hierover:

"Zelfs voor de overdracht moet de toestemming van de patiënt gevraagd worden, zeker als je iets opschrijft over de psychosociale beweging van de patiënt."

Even later stelt ze wel dat er sprake is van een moeilijke situatie als de patiënt totaal afwijzend is en vult dit aan met:

"Gezien de zorgverlening en de continuïteit is het belangrijk dat de hulpverlening hier verder op door kan gaan. Ze moeten inderdaad weten hoe het is en dat betekent dat ik de informatie toch doorgeef."

Eén ziekenhuisverpleegkundige geeft aan dat de toestemming woor het inschakelen van wijkverpleegkundige zorg niet expliciet wordt gevraagd. Zij veronderstelt dat de patiënt zijn bezwaren wel kenbaar zal maken. Een andere wijkverpleegkundige vindt dat ze geen toestemming voor ontslag aan de patiënt hoeft te vragen, want de datum van ontslag bepaalt de arts. Zijj stelt daarbij:

"Als je geen keuze hebt, dan is het moeilijk om toestemming te vragen."

Eén ziekenhuisverpleegkundige vraagt wel toestemming aan de patiënt voor het inschakelen van wijkverpleegkundige zorg. Het komt volgens haar wel eens voor dat de patiënt thuis geen wijkverpleging wil als de ziekenhuisverpleegkundige dit wel nodig vindt. Op de vraag wat er in zulke situaties gebeurt antwoord zij:

$V$ : "Nou, door te praten komen we tot een conclusie."

$I:$ "En het is uw stem die wint?"

$V:$ "Ik denk het wel."

I: "Waar ligt dat aan?"

$V$ : "Ik denk dat ik het toch nodig vindt dat die man dat krijgt en dat je een stukje nazorg wil geven." 
Eén ziekenhuisverpleegkundige zegt hierover het volgende:

"Als een patient het niet wil dan probeer je hem toch nog wel een keer extra uit te leggen waarom het voor hem belangrijk is dat de wijkzorg een stukje nazorg gaat doen. Willen ze dan nog niet dan gaat het niet door. Het enige dat we dan nog wel doen is dat we een foldertje meegeven van de wijkverpleging, met het telefoonnummer en dan we zeggen van: "Als $u$ mu thuis bent en het valt toch nog tegen en $u$ hebt alsnog behoefte aan die zuster, dan kunt $u$ dat nummer bellen en dan komen ze alsnog." En dan is het aan de wijkverpleegkundige zelf om contact met ons op te nemen."

Wat betreft de informatie-uitwisseling constateert eến ziekenhuisverpleegkundige dat je de wens van de patiënt om bepaalde informatie niet door te geven zoveel mogelijk dient te eerbiedigen. Maar ook zij maakt een uitzondering; informatie dient wel te worden verstrekt als niet informeren de behandeling thuis in de weg. zou staan.

* Op welke wijze wordt toestemming verkregen en vastgelegd?

Een echtgenote geeft aan hoe de familie op eigen initiatief haar echtgenoot wit het ziekenhuis haalt.

E(chtgenote): "Hij was het spuugzat, hij heb er elf weken ingelegen.

En toen zei mijn schoonzoon: "Ik ga hem halen, $i k$ zet hier een bed neer, want dan is hij toch in vertrouwelijke omgeving." Ik zeg: "Nou, dat wind ik een prima idee." En mijn man wond het prima."

I: "En de dokter, wat vond die ervan?"

$E_{.:}$"Ik heb het niet aan de huisdokter gevraagd, in het ziekenhuis wel. Als het een breed huis was dan mocht ie gaan, maar als hij hier naar mijn eigen huis was gegaan dan had het niet gemogen, dan hadden ze hem gehouden.

I:" "En wie heeft bepaald dat uw man naar huis kon?"

E: "Wij zelf, maar dat heb ik niet aan de huisarts gevraagd, die draagt daar geen verantwoording voor, dat heb ik zelf gedaan, toen hebben we hem thuis gebracht."

Patiènten vertellen in de interviews niet op welke wijze zij toestemming hebben gegeven. $\mathrm{Zij}$ vinden deze toestemming ook niet noodzakelijk.

Eén huisarts geeft aan dat strikt genomen "de patiënt voor de informatie-uitwisseling toestemming zou moeten geven en dat hij met zijn neus overal bovenop zou moeten zitten, maar in de praktijk is dit niet werkbaar." Eén specialist zegt alleen tegen de patiënt dat de huisarts een brief krijgt. Een andere specialist geeft als volgt aan hoe hij de ontslagdatum bepaalt:

"Het is een spel wat je speelt. Vandaag heb ik visite gelopen. Toen zei ik. "Nou ik vind eigenlijk wel dat u naar huis kan." Maar mevrouw $S$ zegt dan:" Als het maar voor 9 maart is, want dan is mijn man jarig." En ik had in mijn hoofd dat ze morgen naar huis kon. 
Dan zeg ik: "Zullen we het zaterdag doen?" Hiermee stel ik het eventjes uit zodat ze er wat naar toe kan leven. Nou dat vindt ze prima, in zo'n geval zeg ik niet, dat kan morgen. Een andere patiènt die zegt: "Al was het morgen dokter!" Dan zeg ik: "Nou het kan morgen."

Ook de rol van de wijkverpleegkundige is belangrijk bij de bepaling van de ontslagdatum. Eén specialist zegt hierover:

"De verpleegkundigen hebben toch meer informatie. Meestal is het in de trant van: "Ze moet nu echt naar huis want ze heeft het moeillijk:" Daar houd ik dan rekening mee. Want dat ze het moeilijk hebben zeggen ze niet zo gauw tegen artsen maar eerder tegen de verpleging."

Een andere specialist voegt hieraan toe:

"Ik krijg op mijn donder van de verpleging als ik geen rekening houd met de opvang en nazorg thuis."

Soms vindt de ontslagbespreking plaats waar de patiënt zelf bij is, maar het gebeurt ook wel op de gang of in de hal, afhankelijk van de reden van ontslag.

Artsen geven in de interviews niet aan dat zij de toestemming van de patiènt ergens, hetzij in de verwijs- of ontslagbrief hetzij in het dossier van de patiënt, schriftelijk wastleggen.

Verpleegkundigen lichten in de interviews niet toe op welke wijze de toestemming van de patiënt wordt verkregen. De reden hiervoor is dat zij de toestemming van de patiënt niet als een vereiste beschouwen. Derhalve wordt geen melding gemaakt van het vastleggen van de toestemming van de patiënt in de verslaglegging.

\subsubsection{Het recht op vrije keuze}

In deze paragraaf wordt ingegaan op de vraag waarop de patiënt zijn keuze baseert als hij verwezen wordt naar het ziekenhuis, hoe de huisarts de keuzevrijheid van de patiënt respecteert, of de patiënt op naam van een bepaalde specialist wordt verwezen of dat hij verwezen wordt naar een bepaalde polikliniek en welke keuzemogelijkheden de patiënt bij overdracht van zorg heeft ten aanzien van verpleegkundigen.

* Waarop baseert de patiënt zijn keuze?

Niet alle patiënten worden bij de verwijzing voor een keuze gesteld. Zo vertelt één patiënt:

"Ik had geen keus, het was het enigste ziekenhuis waar ik bestraald kon worden."

Een andere patiënt geeft aan dat hij naar een bepaald ziekenhuis moest omdat daar zijn keelarts werkte. Enkele patiënten geven in de interviews aan geen duidelijke voorkeur te hebben voor een bepaald ziekenhuis of specialist. Zo stelt eén patiënt:

"Het maakt me allemaal niks uit, als ik maar geholpen wordt." 
Een andere patiênt antwoordt op de vraag of ze wel naar dat ziekenhuis toe wilde:

"Nou graag, op dat moment vraag je het niet. $1 \mathrm{k}$ had toen geen voorkeur; ik wou alleen niet naar....(naam ziekenhuis) amdat 34 jaar geleden mijm zoontje daar is overleden."

Eén patiente wil juist verwezen worden naar het ziekenhuis waar zij 50 jaar geleden haar kinderen had gekregen. Dat wond ze een leuk idee. Het ziekenhuis was inmiddels helemaal yerbouwd en goed bereikbaar. Goede ziekenhuiservaringen van vroeger spelen bij meer patiënten een positieve rol bij de keuze. Een patiënte geeft aan dat de arts niet expliciet vroeg naar welk ziekenhuis ze wilde. Zij had echter wel gereageerd als haar dokter haar naar een ziekenhuis had gestuurd waarmee ze slechte ervaringen had gehad. Een andere patiënte geeft aan dat haar arts toelichtte waarom zij dacht dat dat ziekenhuis het beste geschikt was voor haar; haar dokter vertelde haar dat ze daar een reuma-afdeling hadden en ze had reuma.

Volgens huisartsen baseert de patiënt zijn keuze op de goede berichten die hij hoort over een specialist van familieleden, vrienden en bekenden of van de huisarts. Eén huisarts concludeert dat de patiënten ten aanzien van polikliniekbezoek kiezen voor de specialist die het snelste tijd voor ze heeft. Bereikbaarheid van het ziekenhuis voor familieleden en de geloofsovertuiging van de patiënt spelen volgens verschillende huisartsen ook een rol bij de keuze.

Eén specialist geeft aan dat de meeste patiënten kiezen voor de specialist waar ze al vaker zijn geweest. Eén specialist merkt op dat het belangrijk is, dat de huisarts patiënten stuurt naar degene die het meest gespecialiseerd is voor een bepaald probleem. Tenslotte constateert een vrouwelijk specialist dat de meeste patiënten van te voren weten dat ze een vrouwelijke arts is. Vooral buitenlandse vrouwen zouden voor een vrouwelijke specialist kiezen omdat ze anders bij het lichamelijke onderzoek problemen zouden krijgen met hun man.

Volgens verpleegkundigen baseren patiënten hun keuze op parkeergelegenheid, de afstand tot het ziekenhuis, de bereikbaarheid, de ervaring die ze met een ziekenhuis hebben, de gewoonte binnen de familie en de voorkeur van de huisarts. Zo stelt én verpleegkundige:

"De keuze voor een bepaald ziekenhuis komt voor een groot deel woort uit de keuze van de huisarts. Deze kiest voor de specialist waarmee hij het meeste contact heeft."

Eén ziekenhuisverpleegkundige geeft aan niet te weten waarop de patiënt zijn keuze baseert. In een aparte paragraaf wordt ingegaan op de keuzemogelijkheid van de patiënt ten aanzien van de verpleging.

* Hoe respecteert de huisarts de vrije keuze van de patiënt?

Een aantal patiènten geeft te kennen dat de huisarts bij de verwijzing naar het ziekenhuis naar de voorkeur van de patiënt vraagt of hier volgens hen uit zichzelf rekening mee houdt. Eén patiënte stelt dat de huisarts haar wel naar haar voorkeur vroeg maar dat deze vraag niet tot haar doordrong. "Ze had geen gedachten meer." Eén patiënt zegt dat de huisarts gewoon een naam van een ziekenhuis noemde. Hij wist dat dit ziekenhuis dichtbij lag. 
Verschillende huisartsen geven in de interviews aan dat zij de patiënt vragen naar zijn voorkeur. Eến huisarts zegt hierover:

"In principe is de patiënt vrij om te kiezen, maar mïn ervaring is gewoon dat ze aan mij advies vragen. Ik zeg bij mijn advies dat de patiënt vrij is om te gaan waar hij wil."

Eén huisarts geeft aan dat het nooit zover is gekomen dat hij de keuze van de patiënt moest afraden. Een huisarts zegt hierover:

"Soms verschilt de voorkeur van de patiënt met die van de huisarts. Dan praten we daarover en dan komen we er op den dutur wel uit. Ik heb argumenten en hij heeft argumenten, ik weet niet wie er uiteindelijk wint."

Eén huisarts maakt een onderscheid in keuzemogelijkheid tussen een acute en niet acute verwijzing en zegt hierover:

"In acute situaties ga je alleen maar na waar de patiënt bekend is, maar als daar geen plaats is dan gaat het over. Als het niet acuut is, maar de specialist heeft geen bed wrij dan oefenen we vaak invloed uit als de patiënt bekend is in een bepaald ziekenhuis. Ze kunnen dan een overbed maken."

Tenslotte geeft én huisarts aan dat hij de patiënt adviseert, bijvoorbeeld bij speciale kinderproblemen.

Verpleegkundigen geven in de interviews geen informatie over de wijze waarop de huisarts de vrije keuze van de patiënt respecteert.

\section{* Verwijzing op naam van de specialist of naar specialisme?}

Patiënten maken in de interviews geen onderscheid tussen een verwijzing op naam van een specialist en een verwijzing naar een bepaalde polikliniek. De meeste patiënten geven aan dat ervaringen met een bepaald ziekenhuis, de bereikbaarheid en de het advies van de huisarts bepalend zijn voor de keuze van een bepaald ziekenhuis. Voor slechts één patiënt is de keuze van de specialist bepalend voor de keuze van het ziekenhuis. Hij zegt hierover:

"Ik werd verwezen naar een bepaalde keelarts en daarvoor moet je naar dat ziekenhuis."

Huisartsen geven verschillende motieven waarom ze een patiënt op naam van een specialist verwijzen. Bijvoorbeeld als de huisarts veronderstelt dat het probleem de interesse heeft van een bepaalde specialist. Eén huisarts zegt over zijn keuze:

"Als een specialist in onze stijl werkt dan stuur ik de patiënt daar naar toe. Mijn keuze licht ik wel aan de patiënt toe."

Deze huisarts geeft well aan de specialisten te kennen van praatjes in het ziekenhuis die hij bijwoont en zegt vooral telefonisch contact met ze te hebben. Eén huisarts stuurt de patiënten naar de polikliniek omdat hij de specialisten niet persoonlijk kent. Een andere huisarts verwijst de patiënt bij gynaecologie en orthopedie op naam omdat hij de specialisten daar kent. Bij de specialismen interne en chirurgie doet hij dat niet omdat patiënten daar toch bij andere specialisten of 
assistenten terecht komen, dãn bij degene naar wie hij heeft verwezen.

Eén huisarts maakt een afspraak met een bepaalde specialist als de patiënt niet zelfstandig is en zelf niet het woord kan doen of als hij denkt dat het probleem specifiek geschikt is voor een bepaalde specialist. Bovendien houdt hij hierbij rekening met de karakterstructuur van de specialist.

Een specialisit constateert dat huisartsen patiënten op naam verwijzen als het acuut is. Een internist geeft aan dat patiënten zowel op naam, maar ook naar de interne poli worden verwezen. Hierbij geeft hij aan dat het specialisme interne een groot vakgebiled is waar de meeste specialisten een bepaald aandachtsgebied hebben. Als de patiënt geen voorkeur heeft voor een bepaalde specialist dan kijkt de secretaresse bij wie de afspraak het handigste uitkomt. Een andere specialist stelt dat er geen verschil bestaat in verwijzing tussen particulier en ziekenfonds verzekerde patienten.

Verpleegkundigen gaan in de interviews niet in op een verschil tussen verwijzingen op naam van een specialist of naar een polikliniek.

\section{* Keuzemogelijkheden van de patiënt ten aanzien van de verpleging.}

Patiënten geven in de interviews geen informatie over de door verpleegkundigen genoemde keuzemogelijkheid bij verwijzing naar of ontslag uit het ziekenhuis. De reden hiervoor zou kunnen zijn dat patiënten zich niet meer herinneren welke informatie verpleegkundigen verstrekten bij de verwijzing naar het ziekenhuis. De patiënten geven in de interviews niet aan of ze bij ontslag uit het ziekenhuis voor wel of geen wijkverpleegkundige zorg konden kiezen en of ze eventueel uit verschillende wijkverpleegkundigen konden kiezen. Eén patiënt zegt hierover:

"Ik ben geen zuster en zij hebben ervoor geleerd dus ik kan geen wijkverpleegkundige zorg weigeren."

Huisartsen en specialisten praten in de interviews niet over informatie verstrekt door de verpleegkundigen waarmee de patiënt in staat zou zijn een keuze te maken. Bovendien gaan zij niet in op de keuzemogelijkheid van de patiënt voor verpleegkundige zorg.

Eên wijkverpleegkundige geeft aan de patiënt voor verwijzing niet te informeren over verschillen tussen ziekenhuizen omdat dit (deze kennis) haar persoonlijke mening zou zijn. Bovendien zou een patiënt hier ook nooit naar vragen. Eén ziekenhuisverpleegkundige stelt dat de patiënt niet specifiek voor een bepaalde afdeling zou kunnen kiezen in een ziekenhuis. Ook de keuze voor een bepaalde verpleegkundige op een afdeling is beperkt aangezien geen sprake is van teamverpleging. Eén ziekenhuisverpleegkundige zegt hierover:

"Als een verpleegkundige als een rode lap op een stier werkt dan doen we moeite om te zorgen dat die verpleegkundige niet meer bij die patiënt komt."

Meestal wordt echter over het probleem waarom patiënt en verpleegkundige niet goed met elkaar kunnen opschieten gepraat. Dit kan ook leiden tot een oplossing. De keuzemogelijkheid van de patiënt tussen verschillende wijkwerpleegkundigen is 
zeer beperkt. De patiënt wordt verpleegd door die verpleegkundige die verantwoordelijk is voor de zorg in een bepaalde wijk. Bij problemen tussen patient en wijkverpleegkundige wordt naar dezelfde oplossingen gezocht als in het ziekenhuis.

\subsubsection{Het recht op privacy}

In deze paragraaf wordt ingegaan op:

* het recht op geheim van de patiënt;

* de doelgerichte wijze van verzameling en vastlegging van gegevens bij overdracht van zorg;

* de duidelijkheid waarmee dit doel is omschreven;

* het niet uitwisselen van gegevens voor een ander doel dan waarvoor ze zijn verzameld.

\section{* Het recht op geheim}

In de interviews met patiënten komt naar voren dat de patiënten van de informatie-uitwisseling op de hoogte zijn als ze de brief of het overdrachtformulier zelf aan bijvoorbeeld de specialist of wijkwerpleegkundige moeten afgeven. Over de inhoud van de informatie worden ze niet geinformeerd, maar dit interesseert hen niet. Eén patiënt zegt hierover: " Zo nieuwsgierig ben ik nou ook weer niet."

In de paragraaf over de informatieverstrekking aan de patient wordt ingegaan op de kennis van de patiënt over de inhoudelijke kant wan de informatie-uitwisseling.

Uit de interviews met de artsen blijkt dat informatie bij overdracht van zorg schriftelijk, maar ook mondeling wordt doorgegeven. Zo antwoordt één huisarts op de vraag of hij de specialist wel eens opbelt:

"Het kan voorkomen dat ik de specialist bel met informatie die ik niet in de brief heb gezet...met name als een patiënt heel ongerust is over bepaalde dingen. Psycho-sociale informatie schriff ik niet in de brief, maar die geef ik ook niet telefonisch door omdat $i k$ ook wel eens het gevoel heb dat je contact daar zeer gekleurd door is en dat ik de mening wil hebben van de specialist die wrij is op dat gebied. Het kan zijn dat het wel ter sprake komt in tweede instantie met de specialist."

Deze huisarts vervolgt:

"Vroeger gaf ik eerder gegevens door zonder overleg met de patient dan tegenwoordig. Ik denk dat ik daar zorgvuldiger in geworden ben." $I_{:}$"Hoe is dat gekomen?"

H: "Nou, dat je steeds meer probeert gelijkwaardig met degene die tegenover je zit te communiceren."

Eén huisarts stelt dat hij bij de gegevens-uitwisseling rekening houdt met Beroepsregels; hij brieft geen informatie door als de patiënt dit niet zou weten. Een andere huisarts zegt hierover:

"We hebben de afspraak dat patiënten weten dat we contact hebben met elkaar en als ik iemand verwijs dan vraag ik of het goed is dat ik contact leg." 
Uit de interviews met verpleegkundigen blijkt dat zij de patiënt niet altijd informeren omtrent het contact met collega's in het andere echelon. Op dit feit is in de paragraaf rond de informatieverstrekking nader ingegaan. Ook komt uit de interviews met verpleegkundigen naar voren dat informatie zowel schriftelijk als mondeling wordt doorgegeven. Als de patiènt accoord gaat met het voorstel om wijkverpleegkundige zorg aan te vragen, wordt hij door ziekenhuisverpleegkundigen niet theer expliciet geînformeerd over het feit dat informatie wordt uitgewisseld. Omdat het een gebruikelijke gang van zaken is dat informatie wordt uitgewisseld veronderstelt een ziekenhuisverpleegkundige dat de patiënt "hiervan weet." Een andere ziekenhuisverpleegkundige zou niet weten of een patiënt hiervan op de hoogte is.

Volgens ến wijkverpleegkundige is het de bedoeling dat de patiènt over de schriftelijke informatie-uitwisseling wordt geïnformeerd. Een andere wijkverpleegkundige stelt dat de patiënt verteld moet worden dat er telefonisch contact is tussen wijken ziekenhuisverpleegkundigen. Dit zou patiënten ook op hun gemak stellen. Eén wijkverpleegkundige vertelt dat zij het overdrachtformulier in het bijzijn van de patiënt invult, een andere wijkverpleegkundige dat hij met een collega verpleegkundige in het bijzijn van de patiënt telefoneert.

\section{* Doelgericht verzamelen en vastleggen van gegevens}

Zoals uit de vorige paragraaf blijkt is de interesse van patiënten voor de professionele informatie-uitwisseling beperkt. In de interviews met de patiënten is daarom niet nader ingegaan op het verzamelen en vastleggen van gegevens bij overdracht van zorg.

Uit de interviews met de artsen blijkt dat huisartsen in hun verwijsbrief aandacht schenken aan een concrete vraagstelling waarbij aanvullende informatie betrekking heeft op het gezondheidsprobleem van de patiënt. Op het feit dat artsen naar het idee van de patiënt meer in de brief schrijven dan strikt noodzakelijk is, wordt in de paragraaf over correctie, aanvulling, verwijdering en vernietiging van gegevens nader ingegaan.

Verpleegkundigen geven in de interviews aan dat zij voor de schriftelijke informatie-uitwisseling voorgestructureerde overdrachtformulieren invullen. Eén wijkwerpleegkundige schrijft liever een eigen overdrachtsbrief omdat ze haar verhaal op het formulier niet $\mathrm{kwijt} \mathrm{kan.} \mathrm{Ziekenhuisverpleegkundigen} \mathrm{vullen} \mathrm{relatief} \mathrm{vaker} \mathrm{een}$ overdrachtformulier in dan wijkverpleegkundigen. De reden hiervoor is dat wijkverpleegkundigen vaak niet of pas na een aantal dagen op de hoogte worden gebracht van de opname van de patiënt in het ziekenhuis. Uit onwetendheid wordt het formulier niet ingevuld of omdat ze het niet meer de moeite waard vinden om. het alsnog te doen.

\section{* Doel aanvaardbaar en duidelijk omschreven}

Zoals al eerder is opgemerkt en uit de beschrijvingen van de resultaten nog zal blijken, wordt in de interviews met patiënten niet nader ingegaan op de professionele informatie-uitwisseling. Reden hiervoor is dat patiënten aangeven niet geïnteresseerd te zijn in deze informatie-uitwisseling. 
Uit de interviews met artsen blijkt dat zij de patient niet expliciet informeren omtrent het doel van de professionele informatie-uitwisseling. Enkele huisartsen schrijven een verwijsbrief om een duidelijke vraag te kunnen stellen aan de specialist naar aanleiding van een gezondheidsprobleem van een patiènt. Specialisten geven aan in voorlopige ontslagbrieven informatie te geven over de medicijnen en diagnose. In het definitieve ontslagbericht wordt hierop uitvoeriger ingegaan. Huisartsen komen overeen met specialisten in wat betreft de beschrijving van de inhoud en het doel van het voorlopige en definitieve ontslagbericht. Eén huisarts zegt het op prijs te stellen alś specialisten aan de patiënt een kort kattebelletje mee zouden geven bij verandering van medicatie.

Uit de interviews met verpleegkundigen blijkt dat ook zij de patiënt niet informeren omtrent het doel van het invullen van het overdrachtformulier. Verschillende ziekenhuisverpleegkundigen geven aan zich wel bewust te zijn van de relevantie van de informatie-uitwisseling. Eén ziekenhuisverpleegkundige constateert verbitterd:

"Op congressen en bijscholingsavonden krijgen wij van wijkverpleeg. kundigen het verwijt geen overdrachtformulieren in te vullen, maar in al die jaren dat ik hier werk heb ik welgeteld wier overdrachtformulieren van wijkverpleegkundigen gekregen!"

Verpleegkundigen werken meer met voorgedrukte formulieren dan artsen. Bij het praten over "het schrijven van een overdracht" blijkt, na doorvragen; dat ze hiermee het invullen van het verpleegkundig overdrachtformulier bedoelen.

\section{* Gegevens niet voor een ander doel gebruiken dan waarvoor ze verzameld zijn}

Het uitwisselen van informatie bij overdracht van zorg is erop gericht de zorg te laten aansluiten, opdat geen overbodige handelingen worden verricht. De zorg van een arts is niet hetzelfde als die van een verpleegkundige. De inhoud van de informatie die een arts uitwisselt zal daarom anders zijn dan die van een verpleegkundige. Het overdragen van specifiek voor de overdracht verzamelde gegevens is in de interviews met patiënten niet nader aan de orde gekomen.

Huisartsen geven in de interviews aan dat zij niet weten of verwijsbrieven, die gericht zijn aan de specialist, door ziekenhuisverpleegkundigen gelezen worden. Eén huisarts zegt hierover:

"Ik heb er geen problemen mee als verpleegkundigen de verwijsbrieven lezen, maar ik denk er nooit aan, van ik schrijf het ook voor de zuster of zo."

Een andere huisarts, voor wie het lezen van verwijsbrieven door verpleegkundigen ook geen probleem is, zegt wel:

"Ik denk dat de vraagstelling veel meer voor de specialist zelf is dan voor de zuster."

Eén huisarts vraagt zich af of verpleegkundigen de brieven mogen lezen, maar concludeert eveneens dat hij het prima zou vinden als ze het zouden doen, omdat hij zich voor kan stellen dat "hij ook nieuwsgierig zou zijn als hij in het ziekenhuis zou werken." 
Een huisarts: veronderstelt dat werpleegkundigen de verwijsbrief niet lezen omdat Wij de brief naar de polikiliniek stuurt.

"De britef komt in handen van een co-assistent", op een polikiniek lopen geen verpleegkundigen rond."

In de interviews geven sommige specialisten aan de verpleegkundige verslaglegging in het algemeen wel eens te lezen "om een breder beeld te krijgen van de problematiek van de patiènt." Met name kunnen zij zo een indruk krijgen van zijn zelfzorgvermogen. Zo zegt én specialist:" Hierdoor weet ik wat een patiënt thuis nog deed."

Enkele ziekenhuisverpleegkundigen geven in de interviews aan de werwijsbrieven van de huisarts te lezen. Eén ziekenhuisverpleegkundige vindt dat "dit beter gedaan zou kunnen worden, maar dat de werkdruk hiervoor te hoog is." Alleen in de nachtdienst zou hier tijd voor zijn. Eén ziekenhuisverpleegkundige stelt dat ze verwijskaarten niet kan lezen omdat de specialist de informatie uit de brief zou verwerken in het dossier van de patiënt. $\mathrm{Zij}$ veronderstelt dat de specialist de brief daarna weggooit omdat zij het niet in het dossier van de patiënt kan terugvinden. Eén ziekenhuiswerpleegkundige leest niet alle brieven maar vaak leest zij ze wel en haalt er de be]angrijke informatie uit.

"Ik vind het prettig om te weten."

Eén wijkverpleegkundige geeft aan dat huisartsen bij individueel overleg de brieven van de specialist laten zien. Hieruit begrijpt ze "hoe zwaar de zaak is en wat er gebeurd is."

Een enkele ziekenhuisverpleegkundige stuurt altijd een copie van het overdrachtformulier naar de huisarts. Hiermee wordt hij geïnformeerd over het inschakelen wan wijkverpleegkundige zorg door ziekenhuisverpleegkundigen. In de interviews geven wijkverpleegkundigen aan dat zij geen copieën van overdrachtformulieren aan specialisten verstrekken. Eén wijkverpleegkundige geeft soms een briefje mee aan een patiënt die op de polikliniek onder controle wan een specialist staat. Hierin vraagt zij bijwoorbeeld of $\mathrm{zij}$ de medicatie mag veranderen.

\subsubsection{Het recht op inzage}

In deze paragraaf zal achtereenvolgens worden ingegaan op de vraag wie inzage heeft in de overdrachtformulieren, c.q. verwijs-en ontslagbrieven, op welke wijze de patiënt inzage krijgt, wanueer de patiënt wel of geen inzage krijgt, of de patiènt afschriften kan krijgen en of de patiënt het recht en de mogelijkheid heeft

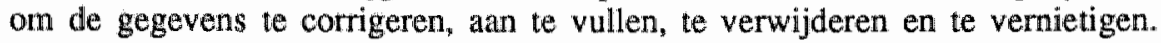

\section{* Wie heeft inzage in de overdrachtformulieren c.q verwijs- en ontslag- brieven?}

Patienten geven in de interwiews aan dat ze artsen en verpleegkundigen niet expliciet om inzage verzoeken. Op de vraag of zij wel eens brieven of overdrachtformulieren lezen antwoordt én patiënte dat zij niet weet of zij de gesloten brief mag openen die de huisarts naar de specialist stuurt. Ook een andere patiënte zou niet weten of ze deze brief zou mogen lezen. Een patiënt merkt op dat hij nog nooit om inzage heeft gevraagd. 
Huisartsen vertellen de patiënten, blijkens de interviews niet dat zij hun de verwijs- en ontslagbrieven mogen lezen. Eén specialist veronderstelt dat de patiênt de informatie die hij naar de huisarts stuurt niet leest. Een andere specialist stelt dat iedere patiënt het recht heeft om zijn eigen status in te zien Eén specialist heeft de indruk "dat patiënten die inzage willen er van te voren van uitgaan dat er dingen instaan die niet kloppen." Een andere specialist geeft aan geen problemen te hebben met het recht op inzage, maar voegt hier aan toe:

"De dingetjes in de kantlijn die de patiënt eigenlijk niet mag lezen zijn ook niet zo interessant voor hem."

Eén specialist beschouwt het verzoek om inzage als een symptoom van een communicatiestoornis. Een andere specialist stelt dat de patiënt het verzoek om inzage in de ontslagbrief maar tot de huisarts moet richten.

Eén wijkverpleegkundige weet niet of patiënten het overdrachtformulier lezen als ze die meenemen naar het ziekenhuis. Ze stelt wel "dat ze de enveloppe altijd netjes dicht plakt." Een andere verpleegkundige constateert dat de patiënt nog nooit om inzage heeft gevraagd. Zelf schrijft ze alleen datgene op wat ze met de patiënt heeft afgesproken.

Eén ziekenhuisverpleegkundige vindt:

"Het recht van de patiënt op inzage kan niet worden onthouden. Pa-

tiënten wragen echter nooit om inzage."

\section{* Op welke wijze krijgt de patiënt inzage?}

Patiènten geven in de interviews aan "een brief van de huisarts aan de specialist te geven." Over de inhoud van deze brief is echter niet veel bekend. Eén patiënte zegt hierover:

$P$ : "Ik kijk nooit in de enveloppe als die dicht is."

I: "Denkt $u$ dat $u$ de brief wel open zou mogen maken als $u$ zou willen?"

P: "Nee, volgens mij mag je een brief niet openmaken, niet als hij dicht is."

Een andere patiënt geeft aan dat hij de brief wel in zijn bezit heeft en hem kan lezen omdat hij alleen maar dichtgevouwen was.

"Hij was niet dicht dus dan mag ik hem best openmaken."

Eén patiënt stelt dat hij de brief naar de cardioloog zo open kan maken, maar voegt hieraan toe dat hij "die hele taal niet kent omdat ze vakjargon praten." Eên patiënt geeft aan het best wel leuk te vinden als de arts zou aanbieden om de verwijsbrief samen te lezen. Hij constateert tevens dat hij dit ook aan zijn arts kan vragen omdat hij een fijne arts heeft.

In de interviews met huisartsen wordt veel verteld over de wijze waarop inzage wordt verstrekt. Eén huisarts vraagt de patiënt niet expliciet om inzage. Een andere huisarts stelt het op prijs als de patiënt de verwijsbrief wil lezen. Hij houdt bij het schrijven dan wel rekening met het feit dat de patiënt de brief leest. Een ande- 
re huisarts geeft de brieven altijd met de patienten mee, dat scheelt hem aan postzegels. Over inzage in de ontslagbrief van de specialist zegt ến huisarts:

H: "Een heel enkele keer wordt door de patient verzocht om de brief van de specialist in te zien. Iemand waarvan ik weet dat hij het echt niet moet lezen, daar zorg ik wel woor dat het niet kan. In andere gevallew, lemand die echt geinteresseerd will lezen, die mag wel.

I: "Hoe ga je dit dan tegen?"

H(uisarts):" Misschien wel niet naar de vraag luisteren, ik weet niet hoe, misschien wel niet horen. Ik kan mij niets voor ogen halen zo."

Een andere huisarts constateert dat patienten weten dat gegevens worden uitgewisseld. Hij weet alleen niet hoe zij dit weten en voegt hieraan toe:

"Ik ga er altijd van uit dat men op de hoogte is, of ik laat het expres merken door te zeggen dat ik heb gehoord dat de specialist tevreden is."

Tenslotte merkt éen huisarts op dat patiênten de brief van de specialist niet kunnen lezen omdat deze na het ontslag van de patiènt binnenkomt. Bovendien stelt hij:

"Maar als ze de brief willen lezen en erom vragen, dan mag de pa-

tiënt deze lezen, maar ze hebben er heel weinig aan."

Deze huisarts had uit recente problemen begrepen dat voor inzage in de ontslagbrief de toestemming van de specialist vereist was.

Ook onder specialisten lijkt de wijze van inzage een belangrijk onderwerp. Eén specialist veronderstelt dat de patiënt de verwijsbrief van de huisarts leest, marar weet dit wiet zeker. Hij heeft er echter geen problemen mee als de patiënt deze brief zou lezen omdat het toch informatie is die hij als specialist ook krijgt. Eén specialist zou alvorens inzage te verlenen overleggen met de huisarts als "er cruciale dingen in zouden staan." Een andere specialist heeft de indruk dat de patiënt de verwijsbrief meestal wel heeft gelezen en zegt hierover:

"Je moet er ook vanuit gaan dat de patiënt de verwijsbrief leest en er dus geen dingen inzetten die de patiënt onthouden moeten worden. lets waar de huisarts aan denkt en wat niet zeker is, daar kan de patiétut maar beter niet aan ruiken."

Specialisten geven in de interviews aan geen moeite te hebben om de patiënt inzage te geven in de ontslagbrief. Verschillende specialisten hebben echter nog nooit het verzoek om inzage hierin gehad. Enkele specialisten geven aan dat de mogelijkheid tot inzage wel invloed heeft op de wijze waarop zij de ontslagbrief schrijven. Eén specialist zegt hierover:

"Ik denk dat je zorguldig moet zijn als je informatie opschriff. Als een keer het woord longkanker in zo'n briefje staat dan gelooft de patiënt voor de rest vam zijn leven dat hij kanker heeft en dat kun je dan niet meer corrigeren."

Wijkverpleegkundigen vertellen in de interviews weinig over de wijze waarop de patie̊nt inzage krijgt. Eén wijkverpleegkundige zegt dat zij het overdrachtformulier 
bij de patiënt invult. Een andere wijkverpleegkundige neemt "de overdracht met de patiënt door als deze hem zelf nog niet heeft gelezen."

Ziekenhuisverpleegkundigen vertellen meer dan wijkverpleegkundigen over de wijze van inzage. Eén ziekenhuisverpleegkundige veronderstelt dat de patiënt niet het overdrachtformulier thuis zal lezen alhoewel ze niet weet wat patienten met het formulier doen. Eén ziekenhuisverpleegkundige weet niet of patiénten behoefte hebben om het overdrachtformulier te lezen. Uit gewoonte plakt zij de brief dicht. Een andere ziekenhuisverpleegkundige maakt de aantekeningen waar de patiënt bij is. Eén ziekenhuisverpleegkundige neemt het overdrachtformulier aitijd met de patiënten door. Zij zegt hier het volgende over:

"Het is heel frappant, maar je kunt bijoorbeeld in de brief schrijven dat de patiënt ontzettend gestimuleerd moet worden om rechtop te lopen. Patiënten kijken je dan aan en zeggen: "Dat is waar, he?" Dat wind ik heel gek, maar het is echt waar."

Eén ziekenhuisverpleegkundige vindt dat zij verplicht is de patiënt inzage te geven als deze hierom zou vragen. Tenslotte stelt én ziekenhuisverpleegkundige dat zij "iets niet zo snel in de overdracht zal schrijven als dit nog niet ter sprake is gekomen." Als ze dit wel doet plakt zij de brief dicht.

\section{* Wanneer krijgt de patiënt wel en wanneer krïgt de patiënt geen inzage?}

Verschillende patiënten geven in de interviews aan niet geïnteresseerd te zijn in wat artsen elkaar schrijven en dus geen behoefte te hebben aan inzage. Eén patiënt zegt hierover treffend:

"Inzage? Nee hoor, ze zeggen het me wel. Als ik iets wraag dan geven ze antwoord. Ik heb niet het idee dat ze dingen achter mijn rug verborgen houden."

Eén patiënt veronderstelt dat datgene wat verpleegkundigen opschrijven voor studiedoeleinden is. Hij weet het echter niet precies, want hij heeft het nooit aan ze gevraagd. Een andere patiënte geeft aan geen behoefte te hebben aan inzage, maar dat de jongere generatie die mondiger is die behoefte misschien wel heeft. In de paragraaf over het toestemmingsvereiste is hier nader op in gegaan. Tenslotte geeft één patiënte als volgt aan dat ze enige twijfels heeft rondom inzage:

"Nou ja, ik weet niet of dat goed is. Het zijn dingen die je misschien beter niet kan weten, we hebben zoveel narigheid gehad. Ik weet niet of je er zoveel aan hebt. Ik hou er niet van om over ziektes te praten en dat soort meer."

Slechts enkele huisartsen geven aan wanneer de patiënt well en wanneer de patiënt geen informatie krijgt. In principe hebben zij geen problemen met inzage van de patiënt.

Specialisten geven in de interviews geen beperkingen aan van het recht op inzage in de verwijsbrief van de huisarts of de ontslagbrief van de specialist. 
Enkele verpleegkundigen geven aan datgene wat ze opschrijven met de patiënt door te nemen. Patiënten vragen volgens hen nooit om inzage, maar als ze dat well zouden doen dan geven verschillende verpleegkundigen aan dat ze dit verzoek niet mogen weigeren.

\section{* Afschriften}

In de interviews is niet gevraagd of de patiënt behoefte heeft aan afschriften, omdat de patienten al hadden aangegeven niet geïnteresseerd te zijn in de inhoud van de overdrachtformulieren en verwijs- en ontslagbrieven.

Artsen geven aan geen bezwaar te hebben tegen het verstrekken van afschriften. In de praktijk zijn zij echter nog nooit met het verzoek om afschriften geconfronteerd zodat zowel huisartsen als specialisten op dit punt geen informatie konden verstrekken.

Eén ziekenhuisverpleegkundige vertelt dat de patiënt een copie van de ontslagbrief van de specialist meekrijgt, die hij thuis kan lezen. Verder praten verpleegkundigen niet over de mogelijkheid van de patiënt om afschriften te krijgen van de overdrachtformulieren.

* Correctie, aanvulling, verwijdering en vernietiging van gegevens.

In de interviews met patiênten wordt niet ingegaan op de mogelijkheid om gegevens te corrigeren, aan te vullen, te verwijderen en te vernietigen.

Artsen geven in de interviews aan dat patiënten behoefte kunnen hebben om gegevens te corrigeren, aan te vullen, te verwijderen of te vernietigen. Eén huisarts geeft als volgt aan hoe de patiënt de mogelijkheid heeft om informatie te corrigeren of aan te vullen:

"Het komt wel eens voor, bijvoorbeeld als ik twijfel of de patiënt het goed zal vinden, dan vraag ik hoe ik het op zal schrijuen. Het is dan miet zo dat ik ga zitten doorstrepen, maar het gebeurt wel eens dat voordat het opgeschreven wordt er eigenlijk gereageerd wordt zoals de patiënt het graag ziet."

Volgens een andere huisarts heeft de patiënt ook de mogelijkheid om de brief niet af te geven.

"Als patiênten denken van nou, dat heeft de dokter niet goed gedaan en ik ben het er niet mee eens, dan zijn ze natuurlijk ook vrij om de verwijsbrief weg te gooien en het te verwoorden."

I: "Komt het wel eens voor denkt u?"

H: "Ik krijg niet altijd gericht antwoord op de verwijsbrief. Het kan zijn dat de specialist niet zoveel met de informatie in de werwijsbrief doet."

Eén huisarts stelt dat mensen verwijsbrieven altijd mogen lezen, verbeteren of aanvullen, maar dan well in overleg met hem. De brief schrijft hij ter plekke. Is hier te weinig tijd voor dan schrijft hij de brief later en haalt de patiënt hem af. Eén huisarts geeft verschillende voorbeelden waarin patiënten reageren op de grote hoeveelheid informatie in de verwijsbrief. Zo was é́n patiënte van streek geraakt 
van de melding van een onduidelijk psychiatrisch opname in het verleden. De huisarts zei hierover:

"Ik heb de brief gewijzigd, waarbij ik tevens heb overwogen dat de specialist er ook wel uitkwam. Meestal vind ik het belangrijk om de voorgeschiedenis in de brief te zetten, dat is makkelijk voor de spe. cialist, dan hoeft hij het niet allemaal uit te puzzelen."

$\mathrm{Bij}$ een andere patiënt die ook vond dat er teveel voorgeschiedenis in zijn verwijsbrief stond heeft hij de voorgeschiedenis toegespitst op het specialisme waar de patiënt terecht zou komen.

Eến specialist zegt over de mogelijkheid van de patiènt om gegevens te corrigeren:

"Patiënten krijgen de brieven die we aan de huisarts sturen helemaal niet te zien, tenzij zij er zelf om vragen."

Dit blijkt in de praktijk echter nauwelijks voor te komen.

Tenslotte merkt éen specialist op dat sommige patiënten bepaalde informatie, bijvoorbeeld of iemand een zieke indruk maakt, beschouwen als een persoonlijke aanval. Hij zegt hierover:

"Je moet je terminologie aanpassen omdat patiënten anders dingen niet zouden snappen. Wetenschappelijk twiffels moet je er niet in zetten, omdat dat verkeerd begrepen wordt."

De mogelijkheid tot vernietiging van gegevens wordt in de interviews met artsen niet besproken.

Eén wijkverpleegkundige heeft zelf nog nooit meegemaakt dat patiënten de behoefte hebben om iets bij de overdracht te schrijven of te veranderen. Ze kan zich wel voorstellen dat patiënten deze behoefte zouden hebben.

Eén ziekenhuisverpleegkundige vraagt na het doornemen van de overdracht met de patiënt of er nog aanvullingen zijn. Tot haar verbazing reageren patiënten heel snel met:

"Ik vertrouw het wel hoor."

Dan moet ze zeggen:

"Ik wil dat u weet wat ik schrijf en misschien will $u$ er wat in hebben wat ik niet erbij heb gezet, weet ik het. Nou dat vinden ze wel leuk."

Tenslotte merkt één ziekenhuisverpleegkundige op:

"Bij het schrijven van de overdracht houd ik geen rekening met het feit dat de patiënt de overdracht kan lezen, omdat hij best mag weten hoe hij overkomt bij de ander."

De mogelijkheid van de patiënt tot verwijdering of vernietiging van gegevens komt in de interviews met verpleegkundigen niet ter sprake. 



\section{DISCUSSIE}

\subsection{Inleiding}

In dit hoofdstuk wordt ingegaan op de resultaten uit de interviews in het licht van het juridisch kader. Andere bronnen die zijn geraadpleegd naar aanleiding van de resultaten uit de interviews, zoals ander onderzoek, (toekomstige) wetgeving die nog miet in hoofdstuk 3 is besproken en aanvullende gesprekken met onder andere verpleegkundigen continuilteit van zorg, worden in dit hoofdstuk indien relevant, gebruikt.

\section{$5.2 \quad$ Het recht op informatie}

In deze paragraaf wordt ingegaan op de vragen wie de informatie verstrekt, waarover en op welke wijze de patiënt wordt geïnformeerd en wanneer wel en wanneer geen informatie wordt verstrekt.

\section{* Wie verstrekt de informatie?}

Als de patiënt in het ziekenhuis wordt opgenomen is sprake van overdacht van verantwoordelijkheid voor zorg van de patiënt. Uit een interview met een huisarts blijkt dat hij zich ook na opname van de patiënt in het ziekenhuis verantwoordelijk voelt voor onder andere het verstrekken van informatie aan de patiënt en zijn familie, hetgeen kan interfereren met het beleid van de specialist. Ondanks dit verantwoordelijkheidsgevoel is het voor de duidelijkheid van de patiënt van belang om toch het volgende uitgangspunt te hanteren: degene die de patiënt behandelt/verzorgt informeert de patiënt. Uit de interviews met patiënten blijkt dat zij in het ziekenhuis door de specialist worden geïnformeerd. Een specialist geeft aan dat hij de informatieverstrekking ook wel eens aan de huisarts over laat, wanneer deze de patiënt beter kent. Bij dit soort beslissingen, waarbij het algemene uitgangspunt wordt losgelaten (degene die de patiënt behandelt informeert) zijn overleg en duidelijke afspraken over wie de patiënt informeert en wat er gezegd wordt van groot belang. Als de specialist op het moment van het ontslag nog niet alle (onderzoeks)gegevens/uitslagen in zijn bezit heeft dient de huisarts de patiënt, zodra hij de gegevens van de specialist heeft ontvangen, te informeren. De specialist is verantwoordelijk voor het zo spoedig mogelijk informeren van de huisarts.

Bij ziekenhuisverpleegkundigen ligt de verantwoordelijkheid voor het verstrekken van informatie bij degene die de patiënt (op dat moment) verzorgt. Bij wijkverpleegkundigen is het meestal duidelijker wie verantwoordelijk is voor de zorg dan bij ziekenhuisverpleegkundigen, waar over het algemeen steeds verschillende ver- 
pleegkundigen voor (een deel van) de zorg vain een patiënt verantwoordelijk zijn (takkgerichte verpleging)'. Informatieverstrekking door de hoofdverpleegkundige is in dergelijke situaties wenselijk. Patiënten geven in de interviews ook aan dat de hoofdverpleegkundige degene is geweest met wie zij gedurende hun ziekenhuisopname het meest contact hebben gehad. Het uitgangspunt dat degene die de patiënt verzorgt ook informeert, wordt bij taakgerichte verpleging losgelaten.

\section{* Waarover wordt informatie verstrekt?}

In de interviews met patiënten komt naar voren dat zij bij verwijzing naar het ziekenhuis niet over hun gezondheidstoestand, de reden van de verwijzing, keuzemogelijkheid, professionele informatie-uitwisseling en inzage mogelijkheid worden geïnformeerd. Dit komt onder andere omdat patiënten zich niet meer (precies) kunnen herinneren welke informatie hen voor de verwijzing naar de specialist is verstrekt. Hierdoor lijkt het alsof de patiënten niet worden geïnformeerd. Deze conclusie mag dus niet zonder meer worden getrokken. De resultaten uit het observatie-onderzoek van Busschbach en Verhaak (1987) naar het arts-patiënt gesprek vormen een interessante aanvulling. De onderzoekers komen tot de conclusie dat de patiënt in ongeveer de helft van de gevallen geen instructies krijgt omtrent de verwijzing.

Ondanks dat overdracht van zorg een belangrijke gebeurtenis lijkt, kunnen patiënten zich niet meer precies herinneren wat er rondom de verwijzing gebeurd is en wat hen verteld is. Wordt de overdracht dan wel als een belangrijke gebeurtenis ervaren? Lijkt het niet meer op een wanzelfsprekende gebeurtenis (de huisarts kan niet meer verder behandelen en verwijst door), waarbij de patiènt zich overlevert aan de hulp van de beroepssbeoefenaar. Deze veronderstelling is gebaseerd op de geringe betrokkenheid van de patiënt bij het selecteren specialist/ziekenhuis en het ontbreken aan interesse in de professionele informatie-uitwisseling.

De geringe betrokkenheid van de patiënt mag voor de hulpverlener geen argument zijn om de patiënt niet te informeren. Ook een niet geïnteresseerde patiënt heeft recht om geînformeerd te worden over de hierboven besproken aspecten.

Patiênten kunnen zich iets meer herinneren van de informatie die hen bij ontslag uit het ziekenhuis is verstrekt dan van de informatie die hen bij verwijzing naar het ziekenhuis is verstrekt. Uit de interviews zou men kunnen concluderen dat ze niet geînformeerd worden over het verloop van het genezingsproces, leefregels, risicobeperking en informatieverstrekking aan en eventuele inschakeling van derden. Met deze conclusie dient men echter voorzichtig te zijn omdat patiënten in de interviews waarschijnlijk niet over al deze aspecten hebben gesproken. Dit kan (wederom) te maken hebben met het herinneringsvermogen van patiënten. Uit de interviews blijkt verder dat één patiënt naar zijn gevoel niet voldoende is geïnfor-

${ }^{\prime}$ Bij integrerende verpleegkunde en teamverpleging is duidelijk afgesproken welke verpleegkundige verantwoordelijk is voor de zorg van een patiënt. 
meerd en dat hij niet in staat is de verlangde informatie te verkrijgen. Een patiènte geeft aan hier wel in te zijn geslaagd. Dit kwam volgens haar door hatar positieve opstelling.

Uit de interviews met huisartsen blijkt dat infomatie over een ongewenste prognose niet altijd aan de patiënt wordt verstrekt. Deze informatie wordt soms wel in de verwijsbrieven geschreven. Patiënten lezen deze professionele informatieoverdracht niet.

Het verzoek van de patiënt om inzage mag er niet toe leiden dat beroepsbeofenaren informatie uitsluitend mondeling uitwisselen in plaats van schriftelijk. Artsen en verpleegkundigen kunnen hiertoe overgaan omdat ze de patiënt niet willen informeren omtrent de inhoud van de professionele informatie-overdracht, bijvoorbeeld bij een ongunstige (voorlopige) diagnose. Mondeling verstrekte informatie kan echter vergeten worden. Op de nadelen van het uitsluitend mondeling verstrekken van informatie wordt in paragraaf 5.5 ingegaan. Bovendien heeft de beroepsbeoefenaar de plicht om een dossier bij te houden, waaruit de plicht tot het schrijven van verwijs- en ontslagbrieven c.q. ontslagformulieren kan worden afgeleid (art. 1653i Voorontwerp geneeskundige behandelingsovereenkomst). Deze brieven en formulieren maken duidelijk welke informatie wel en niet is uitgewis-

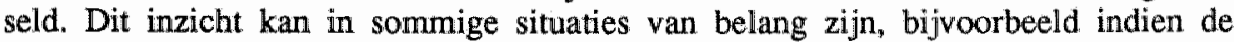
specialist onvoldoende geinformeerd is door de huisarts en hierdoor een medische fout maakt.

Het verdient geen voorkeur om de patiënt alleen te informeren over ernstige vermoedens om hem hiermee te "motiveren" naar een specialist te gaan. Men kan zich zelfs afvragen of deze informatie juist niet een omgekeerd effect heeft bij de patiënt: hij schrikt zó dat hij het bezoek aan het ziekenhuis uitstelt.

De patiënt dient geïnformeerd te worden over de reden van de verwijzing (paragraaf 4.3.2). Voor de huisarts kunnen dit verschillende redenen zijn zoals diagnostiek, behandeling, behandelingsadvies, geruststelling, ondersteuning van eigen beleid, second opinion, documentatie voor een te verwachten (af)keuringsprocedu re. De patiënt kan verwezen willen worden omdat hij onvoldoende vertrouwen heeft in de huisarts, zijn ziekterol wil legitimeren of angstig en onzeker is over de klacht. Duidelijkheid omtrent elkaars verwachtingen kan de vertrouwensrellatie vergroten.

De huisarts dient niet te snel te veronderstellen dat de patiënt bepaalde procedures rondom de verwijzing kent. Hij en in tweede instantie ook de specialist zullen de patiënt zoveel mogelijk moeten voorbereiden op de polikliniek en/of opname. Informatie, warvan de inhoud reeds in paragraaf 3.3 .2 is weergegeven, speelt hierbij een belangrijke rol.

Uit de interviews blijkt dat een huisarts relatief weinig aandacht schenkt aan het verstrekken van informatie die van belang is voor het maken van keuzes. De arts dient de patiẻnt te wijzen op de keuzemogelijkheid. Als het maken van een keuze voor de patiènt een probleem is (omdat hij gewoon niet weet waarop hij moet 
letten) kan de arts verschillende alternatieven benoemen en daarbij voor- en nadlelen angeven. Een voorwaarde hiervoor is dat huisartsen, maar ook specialisten, voldoende geinformeerd zijn over:

- de kennis en vaardigheden van verschillende specialisten (technisch en sociaal);

- behandelingsmogelijkheden in verschillende ziekenhuizen;

- wachttijden.

Deze informatie kuninen zij krijgen via de patiènt zelf (ervaringen die zij met patiënt hebben bij verwijzing en ontslag, tevredenheid patiënt over de specialist), de ontslagbrieven (hoe beantwoordt specialist vraag in verwijsbrief, wat is met patiènt in ziekenhuis gebeurd), refereerbijeenkomsten (inzicht in technische mogelijkheden) en persoonlijke contacten (inzicht in sociale kwaliteiten specialist).

Indien de patiënt accoord gaat met het voorstel om wijkverpleegkundige zorg aan te vragen, wordt hij, ten onrechte, door ziekenhuisverpleegkundigen niet meer expliciet geînformeerd over het feit dat informatie wordt uitgewisseld. Evenmin wordt hij geînformeerd over de inhoud van deze informatie. Verpleegkundigen zouden zich meer dan nu het geval is moeten realiseren dat de patiënt wel recht heeft op deze informatie omdat het gaat over het verstrekken van informatie aan derden.

Specialisten geven in de interviews aan dat zij de patiènt omtrent de professionele informatie-uitwisseling informeren. Op de vraag aan een specialist hoe hij de patiënt hierover informeert (om te checken of hij werkelijk de informatie verstrekt) antwoordt hij dat het hem nog nooit is overkomen dat een patiënt hem verzocht heeft iets niet aan de huisarts door te geven. Onduidelijk is of de specialist de patiënt expliciet informeert omtrent de professionele informatie-uitwisseling.

Beroepsbeoefenaren zouden duidelijker dan nu het geval lijkt te zijn, aan moeten geven wat de inhoud van de brief of het formulier is.

\section{* Wanneer wordt wel en wanneer wordt geen informatie verstrekt?}

Artsen geven in de interviews aan dat zij in principe de patiënt informeren. De inhoud van de informatie en de wijze waarop de informatie wordt verstrekt wordt aangepast aan het begripsniveau van de patient. Slechts eén huisarts geeft aan oudere patiënten die de informatie niet meer zouden begrijpen, ook niet meer te informeren. Het uitgangspunt dient echter te zijn dat artsen de informatie aanpassen aan het begripsnivesu van de patiënt (hoofdstuk 3). Mogelijk spreekt desbetreffende arts over meerderjarige handelingsonbekwame patiënten. In het kader van dit onderzoek wordt op deze problematiek niet nader ingegaan.

Informatie die de huisarts heeft gekregen via een familielid, bijvoorbeeld over een erfelijke ziekte, maar die hij niet aan de patiënt mag verstrekken in verband met de privacy van het familielid kan, indien voor de behandeling van belang, worden doorgegeven aan de specialist. Deze informatie kan schriftelijk worden verstrekt. Hierbij verdient het de voorkeur om de verwijsbrief per post te versturen. Indien de patiènt om inzage verzoekt kan hem in deze situatie het inzagerecht worden onthouden in verband met de privacy van het familielid. 
De huisarts mag de specialist informatie verstrekken die hij, ondat hij vreest dat dit voor de patięnt nadelig is, (nog) niet heeft besproken met de patiènt (therapeutische exceptie). Deze informatie kan per post worden verstuurd. Indien de patient om inzage verzoekt kan de huisarts toelichten waarom inzage in deze fase wordt ontraden. De patiënt heeft echter, ondanks het negatieve advies van de arts, recht op inzage. Eventueel schadelijke gevolgen vallen in dit geval onder zijn verantwoordelijkheid. Het Nederlands Huisartsen Genootschap (NHG) adviseert de "therapeutische exceptie" zo min mogelijk te hanteren. Doch, informatie die niet aan de patiënt wordt verstrekt in het kader van de therapeutische exceptie, mag wel aan een specialist worden verstrekt. Het recht op privacy wordt namelijk niet aangetast als de patiënt wel wordt geïnformeerd over het feit dat informatie wordt uitgewisseld. Tenslotte dient te worden opgemerkt dat patiënten argwaan kunnen krijgen en mogelijk ook ongerust worden als de huisarts tegen zijn gewoonte in, de verwijsbrief naar de specialist opstuurt in plaats van met de patiënt meegeeft (NHG 1989).

In de interviews met patiënten komt naar voren dat patiënten artsen doorgaans niet verzoeken om hen niet te informeren. Een patiënt vindt het brutaal om dit te vragen. Niet bekend is in hoeverre patiënten weten dat ze dit mogen vragen.

Patiënten laten artsen c.q. verpleegkundigen bepalen welke informatie aan hen verstrekt wordt. Dat hun houding en vragen wel van belang zijn voor de informatieverstrekking blijkt uit de interviews met artsen. Als de patiënt bijvoorbeeld niet doorvraagt en geen interesse toont krijgt hij minder informatie dan wanneer hij dit wel zou doen. De patiënt dient, om geïnformeerd te worden, vragen te stellen en zoals een tevreden patiënt stelt -: positief te staan ten opzichte van voorstellen van een arts. Een dergelijke houding kan niet van iedere patiënt worden verlangd. De arts dient derhalve ook bij minder geïnteresseerde of geïnteresseerd lijkende patiènten begrijpelijke informatie te verstrekken.

\section{* Wijze van informatieverstrekking}

De informatie dient te worden afgestemd op het begripsniveau van de patiënt. Uit eén interview blijkt dat een arts ook rekening houdt met het bevattingsvermogen van de patiënt; is de patiënt helemaal geblokkeerd, dan laat hij de patiënt terugkomen als deze wat gekalmeerd is. Dit tijdsaspect komt ook in de jurisprudentie terug; voor het vertrekken van informatie dient de tijd te worden genomen (paragraaf 3.3.2).

Schriftelijke informatie kan voor de patiënt een waardevolle aanvulling betekenen op de reeds mondeling verstrekte informatie. Het Nederlands Huisartsen Genootschap (1989) geeft aan dat het slechts in enkele gevallen (5\% van de verwijzingen) ongewenst is de verwijsbrief aan de patiënt mee te geven. Een reden hiervoor kan bijvoorbeeld zijn het noemen van een diagnose met ongunstige prognose. In een dergelijke situatie dient de huisarts de verwijsbrief per post aan de specialist toe te zenden. Het meegeven van een gesloten brief aan de patiënt moet worden vermeden (NHG 1989). 
In sommige vakliteratuiur wordt gesteld dat een copie van de werwijs- en ontslagbrief c.q. overdrachtfornulier de patient kan helpen zich afspraken te herinneren. De hulpverlener kan echter zonder veel extra moeite een nieuw briefje of een folder aan de patiênt werstrekken. Het mondeling uitwisselen van de informatie tussen beroepsbeoefenaren tast, zoals eerder is beargumenteerd, de privacy van de patièt aan en biedt geen garantie dat de informatie wordt onthouden.

Informatie omtrent de medische diagnose dient door de arts zelf en niet door de familie aan de patiênt te worden verstrekt. Onduidelijk is wat een specialist in een interview bedoeld met het "samen met de familie verstrekken van informatie". Als dit betekent dat de familie de patiënt eerst informeert terwijl de specialist zorgt voor aanvulling c.q. verduidelijking, onttrekt hij zich in eerste instantie van zijn informatieplicht ten opzichte van de patiënt. Bovendien betekent een dergelijke werkwijze dat de familie eerder is geinformeerd dan de patiënt, hetgeen in principe een verkeerde volgorde is! Informatie van de specialist aan familieleden betekent het verstrekken van informatie aan derden, waarvoor de toestemming van de patient vereist is.

Tenslotte verdient het de voorkeur dat verpleegkundigen vragen die niet op hun werkterrein liggen, doorgeven aan de behandelend arts opdat deze de patiënt kan informeren (mocht hij om een of andere reden de informatie uit zichzelf nog niet hebben verstrekt). Dit voorkomt dat de patiënt verschillende (mogelijk tegenstrijdige) verhalen te horen krijgt. De arts is verantwoordelijk voor het verstrekken van begrijpelijke informatie omtrent de medische behandeling. Hij dient derhalve niet uit te gaan van de eventuele mogelijkheid dat de verpleegkundige zorgt voor uitleg van/toelichting op zijn verhaal. Zelfs niet als de verpleegkundige bij de informatieverstrekking aanwezig is geweest. Het argument dat de verpleegkundige de patiënt meer ziet en beter kent dan de arts ontheft hem niet van zijn informatieplicht ten opzichte van de patiënt.

\section{3}

Het toestemmingsvereiste

In deze paragraaf wordt ingegaan op de vragen waarvoor toestemming wordt gegeven en op welke wijze de toestemming wordt verkregen en vastgelegd.

* Waarvoor wordt toestemming gegeven?

Patiènten geven in de interviews aan dat zij het niet nodig vinden om toestemming te geven voor de professionele informatie-uitwisseling; beroepsbeoefenaren mogen volgens verschillende patiënten zelf bepalen welke informatie wordt uitgewisseld. Wel wordt de veronderstelling geuit dat de jongere generatie misschien mondiger zou zijn en die behoefte om toestemming te geven wel zou hebben. Aangezien geen jonge patiënten in het onderzoek konden worden betrokken kan niet nader op deze veronderstelling in worden gegaan.

Artsen en verpleegkundigen kunnen in eerste instantie niet aangeven waarvoor toestemming van de patiënt binnen het overdrachtsproces nodig is. Bij het beantwoorden van gerichte vragen, zoals: "Is de toestemming van de patiënt vereist 
voor de verwijzing?", blijkt dat de toestemming van de patiënt niet expliciet wordt gevraagd. Kennelijk wordt uitgegaan van veronderstelde toestemming.

Een huisarts geeft aan dat een patiënt hem eens verzocht heeft bepaalde informatie niet door te geven. Hieruit zou kunnen blijken dat de patiënt, mits geïnformeerd over het feit dat informatie wordt uitgewisseld, een duidelijke rol kan spelen bij de informatie-overdracht. Voor deze patiènt betekent een verwijzing naar een specialist niet automatisch dat alleen de arts bepaalt welke informatie wordt overgedragen. De arts dient de wens van de patiënt te respecteren. Indien hîj echter tot de conclusie komt dat deze informatie toch verstrekt dient te worden en overleg niet tot een oplossing leidt, kan in het uiterste geval de huisarts besluiten de patiënt niet over te dragen.

Uit de interviews zou men kunnen concluderen dat artsen en verpleegkundigen te snel uitgaan van het feit dat patiënten zelf wel hun bezwaren kenbaar maken en dat derhalve expliciete toestemming niet vereist is. Nogmaals: als patiënten bijvoorbeeld niet weten dat informatie wordt uitgewisseld kunnen ze hiertegen ook geen bezwaar maken.

Een ziekenhuisverpleegkundige geeft aan dat ze de beslissing om een wijkverpleegkundige in te schakelen aan de patiënt overlaat nadat ze haar keuze heeft gemotiveerd. Indien de patiënt geen wijkverpleegkundige nazorg wil, verstuurt ze geen informatie aan de wijkverpleegkundige. Ze laat het van de wijkverpleegkundige afluangen of deze, nadat de patiënt toch om wijkverpleegkundige zorg heeft gevraagd, om informatie verzoekt. De ziekenhuisverpleegkundige is in deze situatie niet verantwoordelijk voor het overdragen van de verantwoordelijkheid voor de zorg van een patiënt aan de wijkverpleegkundige (door middel van het verstrekken van informatie). Indien sprake is van een gezondheidsprobleem na ontslag uit het ziekenhuis en indien de patiënt geen wijkverpleegkundige zorg will, dan is de huisarts verantwoordelijk voor de zorg van een patiënt. Dit zou een reden kunnen zijn voor de ziekenhuisverpleegkundige om de huisarts te informeren over de keuze/wens van de patiënt om geen wijkverpleegkundige zorg in te schakelen. De wijkverpleegkundige kan eventueel naderhand bij de huisarts naar de naam van de verpleegkundige in het ziekenhuis vragen zodat zij allsnog om informatie (een schriftelijk overdrachtformulier) kan vragen. Uiteraard bestaan er ook situaties waarin de patiënt niet kan kiezen of hij wijkverpleegkundige zorg wil; deze zorg is een voorwaarde voor zijn ontslag. De ziekenhuisverpleegkundige dient in deze situaties de noodzaak wan wijkverpleegkundige zorg met de patiënt te bespreken en te vertellen dat informatie dient te worden overgedragen. In de meeste gevallen zal de patiënt gebruik willen maken van wijkverpleegkundige zorg en begrijpen dat informatie dient te worden uitgewisseld.

Uit de interviews met ziekenhuisverpleegkundigen blijkt dat zij huisartsen soms copieën sturen van verpleegkundige overdrachtformulieren. Over het recht op inzage in de verslaglegging van een andere discipline wordt in paragraaf 5.5 ingegaan. Uitgangspunt hierbij is dat de ziekenhuisverpleegkundige de patiënt dient te informeren omtrent het feit dat de huisarts een copie van het verpleegkundig overdrachtformulier krijgt. 
De patiènt dient toestemming te geven voor het inschakelen van wijkverpleegkundige zorg en niet de familie. De opvatting van de familie over de behoefte aan wijkverpleegkundige zorg kan inzicht geven in de wijze waarop de familie de thuissituatie inschat. Dit inzicht kan weer gebruikt worden om de patiënt te informeren over de eventuele voor- en nadelen van het al dan niet krijgen van wijkwerpleegkundige zorg.

De toestemming van de patient voor ontslag uit het ziekenhuis is geen vereiste. Het verblijf van een patiënt in het ziekenhuis en de beëindiging daarvan berusten namelijk op een medische indicatie. Zodra deze wegvalt heeft de patiënt geen recht meer op vergoeding van zijn ziektekosten. In de interviews geven artsen wel aan met de wensen van de patiënt en verpleegkundigen rekening te houden bij het bepalen van de ontslagdatum. De opvatting van de huisarts wordt daarentegen niet meegewogen in de ontslagbeslissing. Specialisten geven bovendien aan dat ze niet benaderd zijn door een huisarts omtrent het ontslag van een patiënt. Toch zou de opvatting van de huisarts, meer dan nu het geval is, een belangrijke rol kunnen spelen bij het bepalen van de ontslagdatum. Hij is namelijk degene die na het ontslag de verantwoordelijkheid voor de zorg van een patiënt overneemt. Indien hij bijvoorbeeld om technische redenen tot de conclusie komt dat hij deze verantwoordelijkheid niet op zich kan memen, dan zou de specialist hier rekening mee moeten houden en het ontslagmoment moeten uitstellen. Bovendien dient te worden opgemerkt dat in de toekomst de huisarts volgens de toekomstige Wet BIG ook verantwoordelijk is voor de uitvoering van medisch-technische handelingen door wijkverpleegkundigen. Indien de huisarts zichzelf hiertoe onvoldoende bekwaam en in staat acht, dan dient ook met dit feit rekening te worden gehouden bij de ontslagbeslissing. Dit pleit overigens voor een eigen verantwoordelijkheid voor de wijkverpleegkundige voor het uitvoeren van medisch-technische handelingen, zonder de voorwaarden voor voorbehouden handelingen (BIG art 53).

\section{* Op welke wijze wordt toestemming verkregen en vastgelegd?}

Zoals reeds in de vorige paragraaf is vermeld vinden patiënten het niet noodzakelijk om hun toestemming te geven voor de verwijzing, het ontslag of de professionele informatie-uitwisseling. In de interviews met de patiènten worden geen ervaringen toegelicht of wensen geuit met betrekking tot de wijze waarop de toestemming kan worden verkregen en vastgelegd.

De toestemming van de patiënt voor de verwijzing naar de specialist wordt, blijkens de interviews met huisartsen, niet in het dossier of in de verwijsbrief vastgelegd. Helaas is niet nagegaan of dit wel gebeurt indien de patiënt een dringend verzoek doet om verwezen te worden of indien hij tegen zijn wil wordt ontslagen of opgenomen.

Of de patiënt instemt met het ontslag wordt niet expliciet in de ontslagbrieven en overdrachtformulieren vermeld. Toch zou men kunnen overwegen orn toestemming voor opname en ontslag vast te leggen. Het is een goede gewoonte en bovendien een beroepsplicht om rekening te houden met de wensen van de patiënt. Bovendien geeft het blijk van een systematische afhandeling van zaken. In ieder geval dient "het ontbreken van toestemming van de patiënt" vermeld te worden. 
In deze paragraaf worden de volgende onderwerpen besproken: waarop baseert de patiënt zijn keuze, hoe respecteert de huisarts diens recht op vrije keuze, wordt de patiënt op naam van een specialist of naar een specialisme verwezen en welke zijn de keuzemogelijkheden van de patiënt ten opzichte van de verpleging?

\section{* Waarop baseert de patiënt zijn keuze?}

Patiënten geven in de interviews aan dat zij niet geïnformeerd worden. omtrent mogelijke alternatieven. Hierbij zou men kunnen denken aan informatie over de sexe van de specialist, de ervaringen van de specialist met specifieke problemen (technische vaardigheid), de vaardigheid van de specialist om met patiënten te communiceren, de ervaringen die de huisarts heeft opgedaan met een specialist, nieuwe behandelmogelijkheden in ziekenhuizen buiten de regio en de consequenties als de patiënt kiest voor een ziekenhuis buiten de regio e.d.. Patiënten geven aan verwezen te willen worden naar het dichtstbijzijnde ziekenhuis, vaak het ziekenhuis waar ze goede ervaringen mee hebben gehad.

De vraag kan worden gesteld of patiënten voldoende interesse tonen voor de verschillende onderzoeks- en behandelmogelijkheden. De opmerking: "Het maakt me allemaal niks uit, als ik maar geholpen wordt", geeft aan dat deze patiènt niet geïnteresseerd is in informatie over eventuele verschillen. Een dergelijke houding zal de huisarts niet stimuleren om de patiënt nader te informeren.

Volgens huisartsen spelen wachttijden, bereikbaarheid en geloofsovertuiging een rol bij de keuze van de patiënt. De huisarts lijkt over deze aspecten voldoende geïnformeerd te zijn. Zolang patiënten niet vragen naar informatie over alternatieven zoals hierboven beschreven, zal de huisarts zich niet verplicht voelen om zichzelf hierover nader te informeren.

\section{* Hoe respecteert de huisarts de vrije keuze van de patiënt?}

Uit de interviews met de patiènten blijkt, zoals reeds eerder is gemeld, dat er bij de verwijzing geen sprake lijkt te zijn van een weloverwogen keuze gebaseerd op verschillende alternatieven. Een huisarts stelt dat patiënten om zijn advies vragen als hij hen vraagt of ze voorkeuren hebben. Dit zou de huisarts de gelegenheid geven om eventuele voor- en nadelen van verschillende onderzoeks- en behandelmogelijkheden door te spreken.

Verschillende huisartsen geven aan dat zij zelden de patiènt moeten afraden om naar een "door de patiënt gekozen" specialist te gaan. Een huisarts geeft zijn patiënten de ruimte om hus voorkeur te beargumenteren. Vervolgens licht hij zijn voorkeur toe. Bij deze werkwijze kan worden opgemerkt dat het voor de patiënt moeilijker is om zijn voorkeur te beargumenteren dan voor de huisarts. Niet alleen omdat hij zich doorgaans ziek voelt, maar ook omdat emotionele aspecten bij de keuze een rol kunnen spelen. De arts kan zich daarentegen baseren op praktische ervaringen en verworven kennis. Zijn voorkeur zal hierdoor mogelijk doorslaggevend zijn. Patiënten met een lange reeks ziekenhuiservaringen, bijvoorbeeld 
chronische patiênten, zullen daarentegen een meer gelijkwaardige gesprekspartner zijin.

De huisarts zal de patiënt naar zijn voorkeur dienen te vragen; maar eveneens alternatieven moeten aanbieden en toelichten. Pas daarna is de patiënt in staat een welowerwogen keuze te maken.

Bij overdracht yan zorg hebben huisartsen belang bij de keuze van de patiènt van een specialist. Zij dienen (tot op zekere hoogte) samen te werken met de gekozen specialist (biedt de door de patiënt gekozen specialist hiertoe de mogelijkheid?) en zijn afhankelijk wan zijn berichtgeving.

\section{* Verwijzing op naam van een specialist of naar specialisme?}

Uit de interviews met artsen en patiënten blijkt dat patiënten zowel naar een specialisme als naar een bepaalde specialist worden verwezen. Verwijzingen naar een bepaalde specialist zijn gerichter, maar vergen van de huisarts wel inzicht in de kennis en kunde van bepaalde specialisten. Bovendien kan de klacht van een patiënt dermate vaag zijn dat een gerichte verwijzing niet altijd even zinvol lijkt.

Patiënten lijken op naam te worden verwezen naar de specialist die de huisarts persoonlijk kent. Men kan zich echter voorstellen dat op grond van een ruime informatieverstrekking over kwaliteiten van verschillende specialisten (een soort data-bank of informatiegids), dit principe kan worden losgelaten. Huisartsen zouden patiënten dan ook kunnen verwijzen naar die specialist die een ruime ervaring heeft met bepaalde problematiek en goede successen boekt met zijn behandelwijze.

Een andere mogelijkheid is om patiënten niet op naam te verwijzen maar naar een bepaalde polikliniek omdat daat meer inzicht is in kennis en kunde (en eventuele wachtlijsten) van verschillende specialisten binnen een discipline dan bij de huisarts. Een eenmaal verwezen patiënt zal om financiële redenen misschien niet zo snel door een specialist worden doorverwezen en blijven hangen binnen de muren van een bepaalde afdeling. Het belang van de specialist weegt misschien op tegen dat van de patiënt. Daarom is het misschien toch beter dat de huisarts, voordat hij verwijst, zich zo mogelijk samen met de patiënt, uitvoerig laat informeren over onderzoeks- en behandelmogelijkheden in verschillende ziekenhuizen. Dit soort oriëntaties zijn uiteraard alleen mogelijk in niet-acute situaties.

Het initiatief voor het maken van afspraken in het ziekenhuis kan, als eenmaal tot verwijzing besloten is, zowel van de patiënt als van de huisarts uitgaan. Opvallend is dat als de huisarts een afspraak maakt voor een patiënt in het ziekenhuis (in acute-situaties of als de patiènt niet zelfstandig genoeg is), hij meestal meteen een bepaalde specialist belt. De patiënt wordt in een dergelijk geval meteen op naam van een specialist verwezen. Dit overleg is voor genoemde situaties zinvol, maar dient niet vaker te worden toegepast, aangezien dit zowel de huisarts als specialist extra tijd kost. Lang niet alle verwijzingen behoeven vooraf overleg tussen huisarts en specialist. 
Uit én interview met een huisarts blijkt dat hij een patiënt niet op naam verwijst naar de specialismen interne en chirurgie. Patiënten zouden daar toch bij andere specialisten of assistenten, dan waar hij hen naar toe had verwezen, terecht komen. Het Nederlands Huisartsen Genootschap stelt, dat een huisants in zijn verwijsbrief expliciet dient te vermelden, wanneer hij niet wil dat een andere dan de beoogde specialist de patiënt behandelt. Alleen "op naam verwijzen" lijkt dus niet voldoende. Een uitdrukkelijk verzoek leidt tot de gewenste verwijzing. Men kan zich echter afvragen of dit in de praktijk werkelijk het geval zal zijn.

\section{* Keuzemogelijkheden van de patiënt ten aanzien van de verpleging}

Patiënten lijken hun keuze voor een bepaald ziekenhuis niet te baseren op bijvoorbeeld de kwaliteit van de verpleging. De vraag kan trouwens worden gesteld of hier sprake is van een zelfstandige keuze. Een belangrijk motief voor verwijzing naar het ziekenhuis vormen de medische mogelijkheden. Voorkeur voor bepaalde verpleegkundige zorgverlening is ondergeschikt aan de medische hulp die kan worden geboden. Men zou zich echter voor kunnen stellen dat een patiènt de voorkeur geeft aan integrerende verpleging of teamverpleging in plaats van aan taakgerichte verpleging ${ }^{2}$. Bij zijn keuze voor een specialist en/of ziekenhuis zou de patiënt hier meer rekening mee kunnen houden dan nu het geval is. Voorwaarde is wel dat de huisarts en wijkverpleegkundige de patiënt hierover kunnen informeren en dat zij deze informatie bijvoorbeeld niet beschouwen als "een zuiver persoonlijke mening".

Bij ontslag lijkt de patiënt blijkens de interviews niet te worden geïnformeerd omtrent de keuzemogelijkheid binnen de wijkverpleging. Dit kan te maken hebben met het feit dat deze keuzemogelijkheid zeer beperkt is; de patiënt wordt als regel verpleegd door de verpleegkundige die verantwoordelijk is voor de zorg in een bepaalde wijk. Pas als patiënt en wijkverpleegkundige niet goed met elkaar kunnen opschieten, wordt, nadat over dit probleem is gepraat, soms besloten de patiënt door een andere verpleegkundige te laten verplegen. Men zou zich echter voor kunnen stellen dat een patiënt graag verpleegd wil worden door een mannelijke of juist vrouwelijke wijkverpleegkundige. Deze keuzemogelijkheid (afhankelijk van de beschikbare wijkverpleegkundige) zou de ziekenhuis- of wijkverpleegkundige de patiënt reeds in het ziekenhuis voor kunnen leggen. Uit een gesprek met een verpleegkundige continuïteit van zorg in de randstad bleek dat het soms voorkomt dat een patiënt niet door een verpleegkundige met een donkere huidskleur verpleegd wil worden. Binnen de kruisvereniging wordt dit ervaren als discriminatie van werkneemsters/nemers; de patiënt heeft in principe geen keuzemogelijkheid binnen de wijkverpleging. Overigens kan men zich voorstellen dat patiënten uit ethnische minderheden de voorkeur hebben voor een verpleegkundige die hun eigen taall en culturur kent.

${ }^{2}$ Integrerende verpleging en teamverpleging komen in ziekenhuizen minder valak voor dan taakgerichte verpleging. Deze verhouding kan echter in de toekomst veranderen. 
De patient kan dus niet op dezelfde wijze zijn wijkverpleegkundige kiezen als dat hij zijn huisarts kiest. De vraag kan worden gesteld waarop dit verschil berust. Wordi de wijkverpleegkundige-patiënt relatie als minder persoonlijk beschouwd dan de arts-patient relatie? Vinden patiënten en verpleegkundigen de keuze van een wijkverpleegkundige minder belangrijk dan die van een huisarts? Is men niet gewend aan ewentuele keuzemogelijkheid van een wijkwerpleegkundige of bestaan er eventuele organisatorische problemen? Op deze vragen kon binnen het kader van dit onderzoek niet worden ingegaam.

\subsection{Het recht op informationele privacy}

Zoals reeds in het derde hoofdstuk is vermeld dienen bij de bescherming van het recht op privacy vier algemene beginselen te worden aangehouden. De patiënt heeft recht op geheim en de hulpverlener heeft de plicht om dat geheim te bewaren; de hulpverlener dient de gegevens doelgericht te verzamelen en vast te leggen; het doel van de registratie moet aanvaardbaar zijn en duidelijk zijn omschreven en de gegevens mogen niet voor een ander doel dan waarvoor ze zijn verzameld worden gebruikt. Deze beginselen vormen het uitgangspunt voor de volgende vier paragrafen betreffende het recht op privacy.

\section{* Het recht op geheim}

Bij overdracht van zorg is de expliciete toestemming van de patiënt voor de informatie-uitwisseling niet vereist. Wel dient de patiënt geïnformeerd te worden over het feit dat informatie wordt uitgewisseld. Hierdoor kan de patiënt bijvoorbeeld om inzage verzoeken en in het uiterste geval de arts of verpleegkundige vragen bepaalde informatie niet over te dragen. In principe is de beroepsbeoefenaar zelf verantwoordelijk voor de informatie-uitwisseling. Bij verschil van opvatting met een patiënt over de inhoud van de informatie dient de beroepsbeoefenaar, als de patiënt erop staat dat bepaalde informatie niet wordt overgedragen, eerst na te gaan of het werzoek van de patiënt redelijk is. Indien hij de informatie toch over wil dragen dan dient hij de reden hiervoor aan de patiënt uit te leggen. Blijft het meningsverschil tussen beroepsbeoefenaar en patiënt bestaan, dan kan in het uiterste geval bijvoorbeeld een huisarts besluiten om de patiënt niet te verwijzen. Dit kan alleen als dit geen medische bezwaren oplevert. De arts kan de patiënt eventueel voorstellen een andere arts te consulteren. Zover zal het echter in de praktijk waarschijnlijk niet komen.

Uit de interviews met patiènten blijkt dat zij van de informatie-uitwisseling op de hoogte zijn als ze zelf de brief of het overdrachtformulier aan de specialist of ziekenhuisverpleegkundige afgeven. Patiënten geven niet aan expliciet te worden geinformeerd omtrent de informatie-uitwisseling. Artsen en verpleegkundigen stellen dat patiënten over het algemeen van de informatie-uitwisseling op de hoogte zijn, al zeggen ze daarbij niet dat zij de patiënt hier expliciet over informeren. Het is de vraag of men de patiënt als voldoende geïnformeerd mag beschouwen, als de brief of het overdrachtformulier in het bijzijn van de patiënt wordt geschreven. 
Informatie blijkt ook mondeling te worden uitgewisseld. Ondanks het voordeel wan deze werkwijze - de informatie kan snel worden verstrekt en overleg is mogelijk dient mondelinge informatie als enige manier om informatie te verstrekken te worden ontraden. De reden hiervoor is dat achteraf niet kan worden gecontroleerd of en welke informatie is doorgegeven. Bovendien is degene die de informatie werstrekt afhankelijk van degene die de informatie noteert. Een wijkverpleegkundige kan bijvoorbeeld niet weten of en hoe volledig de door haar mondeling werstrekte informatie door de ziekenhuisverpleegkundige wordt geregistreerd en wervolgens wordt verspreid. Daarom verdient het schriftelijk verstrekken van informatie de voorkeur met de mogelijkheid om bij onduidelijkheden telefonisch contact op te nemen.

\section{* Doelgericht verzamelen en vastleggen van gegevens}

Niet alle door de huisarts of wijkverpleegkundige verzamelde gegevens omtrent een patiënt dienen bij overdracht van zorg te worden uitgewisseld. De vraag kan worden gesteld welke informatie overgedragen dient te worden. In principe mag de beroepsbeoefenaar dit zelf bepalen. Hierbij kan hij wel steun hebben aan normen ten aanzien van de informatie-uitwisseling die binnen de beroepsgroep zijn gesteld. Het Nederlands Huisartsen Genootschap (NHG) publiceerde onlangs (1989) een aantal richtlijnen betreffende de inhoud van verwijsbrieven. Deze dienen enerzijds te bestaan uit specifiek voor de overdracht verzamelde gegevens (naam specialist/ specialisme/ziekenhuis, belangrijkste klacht, (voorlopige) diagnose c.q probleemstelling, vraagstelling) en anderzijds uit gegevens die vermeld staan in het dossier wan de patiënt (aanvullende gegevens, aanvullend onderzoek, reeds ingestelde behandeling en resultaat hiervan). De verwijsbrief bevat een samenvatting van alle voor de verwijzing belangrijke gegevens en is daarmee een weerspiegeling van de kwaliteit van de verwijzing.

Bij het uitwisselen van aanvullende gegevens dient de hulpverlener zich bewust te zijn van het feit dat informatie over psychosociale factoren en familieanamnese tot ongewenste gevolgen kan leiden (NHG 1989). De arts dient zorgvuldig te overwegen of deze informatie voor het gezondheidsprobleem van essentieel belang is, met name omdat patiënten om inzage in de verslaglegging kunnen verzoeken. De "therapeutische exceptie" geldt in het Voorontwerp geneeskundige behandelingsovereenkomst niet ten opzichte wan het recht op inzage.

Aangezien de richtlijnen van het NHG zijn gepubliceerd nadat de interviews waren afgenomen kon niet op de inhoud hiervan worden ingegaan. Het is interessant om te vermelden dat artsen in de interviews geen problemen signaleren bij het verstrekken en ontvangen van informatie. Hun beschrijvingen over de inhoud van de informatie komen in grote lijnen overeen met de inhoud van de richtlijnen wan het NHG.

In de literatuur worden wel eens knelpunten aangegeven in de informatie-uitwisseling tussen specialisten en huisartsen (Oosterhuis, 1974; Ruhe, 1974; Swinkels en Lodewick, 1984; Pop en Keysers 1985). Hierbij wordt met name ingegaan op de tekortkomingen van verwijsbrieven. Beugeling en Van der Wouden (1989) stellen echter dat hierbij vooral de huisartsen verwijsbrieven belangrijk vinden voor de 
verbetering wan de communicatie. ${ }^{3}$. Volgens deze auteurs is nog niet aangetoond wat het rendement is van de verwijsbrief, omdat in de onderzoeken onvoldoende rekening is gehouden met factoren die de inhoud, respectievelijk het effect van de verwijsbrief beînvloeden. Pas als inzicht is werkregen in deze factoren zou verder uitwerken van de inhoud van de optimale verwijsbrief (in samenwerking met speciallisten) zin hebben.

Tenslotte kan nog worden opgemerkt dat de Gedragsregels voor artsen aangeven dat de informatie dient te bestaan uit antwoorden op concrete, gerichte en rèlevante vragen en dient te berusten op verricht onderzoek en (voorlopig) eigen oordeel, toegespitst op het individuelle geval en beperkt tot het terrein dat door de vraagstelling wordt aangegeven (regel 78). De Gedragsregels sluiten tevens aan op de maatstaven geformuleerd door de gemengde commissie van het Centraal Begeleidingsorgaan voor de Intercollegiale Toetsing (Hageman, Van Giffen en Meyboom 1984).

Kruisorganisaties en ziekenhuizen ontwikkelen reeds enige tijd, veelal onafhankelijk van elkaar, voorgestructureerde overdrachtformulieren. Het initiatief in Amsterdam, waarbij wijk- en ziekenhuisverpleegkundigen samen een overdrachtformulier hebben samengesteld (Smitz 1988), verdient navolging. Verpleegkundigen, maar ook andere beroepsbeoefenaren, kunnen namelijk bij elkaar aangeven welke informatie ze nodig hebben om de zorg te kunnen voortzetten.

Hierbij kan worden vermeld dat (nog) geen enkele verpleegkundige beroepsorganisatie standaardrichtlijnen heeft gepresenteerd omtrent de inhoud van het overdrachtformulier.

Ziekenhuisverpleegkundigen overleggen met wijkverpleegkundigen veelal mondeling omtrent de behoefte aan wijkverpleegkundige zorg. Per telefoon wordt globaal afgesproken welke zorg de patiënt nodig heeft en welke zorg de wijkverpleegkundige kan geven. Uit de interviews met de ziekenhuisverpleegkundigen blijkt dat dezen het overdrachtformulier niet altijd invullen en met de patiënt meegeven. $\mathrm{Zij}$ worden niet geprikkeld om te reageren op de door de wijkverpleegkundige verstrekte informatie of een expliciet gestelde vraag, ondat deze veelal ontbreken. Dit komt enerzijds omdat veel patiënten voor opname meestal nog geen wijkverpleegkundige zorg hebben gehad, anderzijds door het feit dat wijkverpleegkundigen de ziekenhuisverpleegkundigen geen overdrachtformulier hebben toegestuurd.

\section{* Doel aanvaardbaar en duidelijk omschreven}

Doelgerichte informatie-uitwisseling dient bij voorkeur aan de hand van een vast sjabloon (eventueel in de vorm van een voorgedrukte verwijs- ontslagbrief/overdrachtformulier) te geschieden (NHG 1989). Dit voorkomt enigszins dat beroepsbeofenaren vergeten informatie over te dragen.

Een dergelijk standaard wordt bepaald door normen, voortvloeiend uit de aard van

"Het achterliggend idee hierbij is, dat de gegevens (mede)bepalend zijn voor het beleid van de specialist. 
het medisch handelen, uit de rechten van de patiènt en de maatschappelijke functie van de geneeskunde (Leenen 1983). Wetenschappelijke gegevens kunnen bepaalde elementen van de standaard onderbouwen (NHG 1989).

Standaard van zorg is geen standaardzorg. Daarvoor kunnen de volgende argumenten worden genoemd (Leenen 1983):

- de condities en reacties van patienten kunnen verschillen;

- het proces van diagnostiek en therapie kent veel onzekerheden:

- causaliteitsproblemen komen in de geneeskunde veelvuldig voor;

- de geneeskunde is steeds in ontwikkeling, nieuwe inzichten moeten een kans krijgen;

- de plaats van handeling kan van belang zijn.

Kortom, standaarden wan zorg moeten flexibel zijn.

De Nationale Kruisvereniging (NK 1985) heeft beschreven wat het doel is van verpleegkundige voorzorg-, nazorg- en terugrapportage en uit welke elementen deze dient te bestaan. Ook het NHG geeft, naast het doel van de informatieuitwisseling en een aantal gedragsregels voor het verwijzen aan waar de zogenaamde "maximum-" en "minimumbrief" uit dient te bestaan. De NK en het NHG zijn overigens beide organisaties gericht op de eerste lijn.

Maatstaven voor de verslaglegging van de specialist aan de huisarts zijn door een gemengde commissie van het Centraal Begeleidingsorgaan voor de Intercóllegiale Toetsing geformuleerd (Hageman, Van Giffen en Meyboom 1984) en (nog) niet door de beroepsorganisatie. Tenslotte wordt ook in de vakliteratuur aandacht besteed aan de inhoud van de informatie van de specialist aan de huisarts (Meyboom en Casparie 1980, Beusekom en Geerlings 1988).

De interviews met artsen en verpleegkundigen geven aan dat de patiënten niet expliciet worden geïnformeerd omtrent het doel van de informatie-uitwisseling tussen beroepsbeoefenaren. In het kader van de overdracht van zorg ligt het voor de hand om te veronderstellen dat deze informatie-uitwisseling plaats vindt ten behoeve van de continuïteit van zorg. Artsen en verpleegkundigen zouden gezien deze brede omschrijving de patiënt kunnen informeren over de reden om in zijn geval gegevens te verstrekken. Bovendien kunnen zij eventuele vragen van de patiënt naar aanleiding van deze informatie beantwoorden.

\section{* Gegevens niet voor ander doel gebruiken dan waarvoor ze zijn verzameld}

Uit de interviews blijkt dat verwijs- en ontslagbrieven c.q. overdrachtformulieren gelezen worden door hulpverleners voor wie de informatie-verstrekking niet (direct) is bedoeld. Volgens de literaturur is de informatie-uitwisseling tussen bijvoorbeeld huisarts en specialist bedoeld om de continuilteit in de geneeskundige zorg van/voor een patiënt te bevorderen. Verpleegkundigen geven in de interviews aan dat deze informatie ook relevant is voor de continuïteit in de verpleegkundige zorg. De vraag kan worden gesteld of om deze reden besloten kan worden om de informatie, die bedoeld is voor artsen, ook beschikbaar te stellen voor verpleegkundigen. De patiënt dient in dit geval hierover geïnformeerd te worden. 
In principe mogen beroepsbeoefenaren elkaars verslaglegging lezen, indien zij betrokken zijn bij de behandeling/verzorging. De patiënt moet er echter well van op de hoogte gebracht worden tussen wie informatie wordt uitgewisseld en wie inzage heeft in de gegevens.

Enkele huisartsen geven aan dat zij niet weten of ziekenhuisverpleegkundigen de verwijsbrieven lezen. Om de patiênt hierover te informeren zouden ze hier eerst zelf van op de hoogte moeten zijn. Het verdient derhalve de voorkeur dat beroepsbeoefenaren brieven en overdrachtsformulieren gericht versturen. De verzender bepaalt wie inzage heeft in de verslaglegging en informeert hierover de patiënt.

Als de huisarts binnen een gezondheidscentrum de wijkverpleegkundige informeert over de door de specialist verstrekte informatie, wordt uitgegaan van veronderstelde toestemming; de patiënt hoeft niet expliciet geïnformeerd te worden omtrent de informatie die wordt uitgewisseld tussen beroepsbeoefenaren werkzaam binnen een team (hoofdstuk 3). De patiënt dient wel te weten wie binnen dit team werkzaam zijn.

\subsection{Het recht op inzage}

In deze paragraaf wordt besproken wie inzage verstrekt, op welke wijze de patiënt inzage kan krijgen en wanneer wel en wanneer geen inzage wordt verstrekt. Bovendien wordt ingegaan op het recht van de patiënt op afschriften en het recht om geschriften te corrigeren.

\section{* Wie verstrekt inzage?}

Uit de interviews met patiënten blijkt dat zij geen brieven of overdrachtformulieren van hulpverleners lezen; ze kunnen derhalve niet aangeven wie inzage verstrekt. Blijkens de interviews met patiënten en verpleegkundigen vragen patiënten aan verpleegkundigen ook nooit om inzage. Artsen geven in de interviews wel aan soms met een dergelijk verzoek geconfronteerd te worden. Men kan zich afvragen of patiënten voldoende geïnformeerd worden over de eventuele mogelijkheid om inzage te krijgen. Artsen geven in de interviews aan dat ze professionele informatie niet $z o$ belangrijk vinden voor de patiënt. Bovendien ervaren zij het verzoek om inzage, zoals reeds in de literatuur wordt gesteld (Leenen 1988, p. 233), als een uiting van wantrouwen of als symptoom van een communicatiestoomis. Helaas hebben patiënten in dit onderzoek geen verzoek om inzage gedaan, zodat niet kon worden nagegaan of patiënten die wel om inzage verzoeken dit bijvoorbeeld uit wantrouwen doen. Wel geeft een patiënte aan dat ze niet het idee heeft dat informatie achter haar rug verborgen wordt gehouden en dat ze derhalve geen behoefte heeft aan inzage.

Inzage kan worden verstrekt in verwijs- en ontslagbrieven c.q. overdrachtformulieren door die arts of verpleegkundige die op dat moment verantwoordelijk is voor de zorg van een patiënt of door degene die de brief heeft geschreven of het formulier heeft ingevuld. Dit betekent bijvoorbeeld dat een patiënt aan zowel zijn huisarts als specialist om inzage in zijn ontslagbrief kan verzoeken. 


\section{* Op welke wijze krijgt de patiënt inzage?}

Blijkens de interviews met patiënten blijkt dat patiënten niet expliciet geïnformeerd worden omtrent het doel en de inhoud van informatie-uitwisseling tussen hulpverleners. Patiënten zorgen soms voor het transport van brieven tussen huisarts en specialist. Zoals uit vorige paragrafen blijkt, lezen ze deze brieven niet en moeten ze naar het doel en de irihoud van de brief raden.

Eén arts geeft aan rekening te houden met het verzoek om inzage van een patiênt: Onduidelijk is op welke wijze hij hiermee rekening houdt. Schrijft hij de verwijsbrief op zodanige wijze dat de patiènt de inhoud begrijpt en streeft hij, meer dan anders, naar objectiviteit, of besluit hij bepaalde informatie niet in de brief te noteren uit angst voor de reacties van de patiënt? Dit laatste zou te betreuren zijn indien deze informatie voor de specialist in het kader van zijn onderzoek en behandeling wel relevant is.

Eén huisarts stelt dat hij soms zorgt dat een patiënt zijn ontslagbrief niet kan lezen omdat hij vindt dat de patiënt die niet moet lezen. Hierbij dient te worden opgemerkt dat de huisarts niet het recht heeft om voor de patiënt uit te maken of hij wel of niet de verwijs- of ontslagbrief mag lezen. Elke patiënt heeft recht op inzage (paragraaf 3.3.6).

Eén huisarts informeert de patiënt over het feit dat hij door de specialist geỉnformeerd is door te zeggen dat "de specialist tevreden is". Met deze impliciete wijze van informeren weet de patient onvoldoende waarom en waarover de huisarts en specialist met elkaar contact hebben gehad en dat bijvoorbeeld de huisarts de schriftelijke informatie van de specialist heeft ontvangen.

Als artsen vanuit hun positie zeggen dat wat zij aan informatie uitwisselen niet interessant is voor de patiënt, is het voor de patiënt moeilijk om toch om inzage te verzoeken. De vraag kan worden gesteld of artsen hun opvatting over desbetreffende informatie aan de patiënt dienen mee te delen. Informatie over het feit dat er informatie wordt uitgewisseld tussen huisarts en specialist alsmede informatie over het doel van deze informatie-uitwisseling is voldoende.

De speciallist dient niet te bepalen wat de patiënt aan informatie onthouden moet worden. Als een patiënt om inzage verzoekt, doet de specialist er verstandig aän de nog niet verstrekte informatie (omdat hij de therapeutische exceptie heeft toegepast) alsnog te geven. De therapeutische exceptie geldt niet voor het recht op inzage (hoofdstuk 3). Bovendien dient men zich te realiseren dat na het verzoek van de patiënt, het niet geven van inzage (ook) tot schade kan leiden omdat de patiènt in onzekerheid leeft omtrent de volledigheid van de mondeling verstrekte informatie.

Specialisten geven aan geen moeite te hebben met het geven van inzage aan de patiënt als deze erom vraagt. Dit kan te maken hebben met het feit dat specialisten zelden met een dergelijk verzoek zijn geconfronteerd. De extra tijd en moeite 
die het hun kost om het verzoek om inzage in te willigen, het uitleggen van de schriftelijke informatie en de eventuele andere gevolgen van het verstrekken van inzage hebben ze blijkens de interviews nog niet ervaren.

Enkele verpleegkundigen veronderstellen dat patiënten de overdrachtformulieren niet lezen, terwijl andere verpleegkundigen niet weten of patiënten het doen danwel hier behoefte aan hebben. Kortom, er bestaat veel onduidelijkheid over de vraag of een patiënt het overdrachtformulier leest. Verpleegkundigen kunnen het overdrachtformulier met de patiënt doornemen en hem vragen of hij het wil lezen. Het formulier kan beter niet in een dichtgeplakte envelop worden meegegeven aangezien dit de patiênt de veronderstelling kan geven dat hij het formulier niet mag lezen. Het voorstel van het Nederlands Huisartsen Genootschap verdient ook hier de voorkeur; indien informatie wordt uitgewisseld waarover de patiënt beter niet geïnformeerd kan worden dient de brief per post te worden verzonden. Door de toenemende automatisering en het ontstaan van geautomatiseerde informatienetwerken kan in de nabije toekomst waarschijnlijk gedacht worden over heel andere methoden van informatie-uitwisseling dan via de patiënt (Klop 1987).

\section{* Wanneer wel en wanneer geen inzage?}

Het recht op inzage van een patiënt geldt ten opzichte van al zijn medische en verpleegkundige documenten, met uitzondering van de persoonlijke werkaantekeningen van de arts of verpleegkundige en de gegevens over derden. Zoals reeds in hoofdstuk 3 is vermeld, kunnen verwijs- en ontslagbrieven c.q. overdrachtformulieren niet tot werkaantekeningen worden gerekend. Informatie over psychosociale factoren en familie-anamnese heeft veelal betrekking op derden. Indien de patiënt zelf niet van deze informatie op de hoogte is gesteld kan hem het recht op inzage worden onthouden. Psychosociale factoren alsmede een uitvoerige familie-anamnese kunnen beter niet in de verslaglegging aan derden worden opgenomen. Uit de interwiews blijkt overigens dat patiënten het recht op inzage niet wordt ontnomen om bovengenoemde redenen. Dit kan, zoals reeds eerder is geschreven, komen omdat patiënten zelden om inzage verzoeken.

Eén patiẻnt geeft te kennen twijfels te hebben rondom zijn recht op inzage. Deze patiênt gaat er hoogstwaarschijnlijk vanuit dat informatie (over narigheid) wordt opgeschreven die hem mondeling niet is verstrekt. Een variatie op een bekend gezegde: "De patiênt vreest het meest voor hetgeen hij niet leest" lijkt op deze situatie van toepassing. Men kan zich afvragen of een patiënt toch niet meer gediend is met een helder verhaal van de hulpverlener, een open en toegelichte brief en de zekerheid dat er voor hem geen geheimen zijn.

\section{- Afschriften}

Blijkens de interviews met patiënten en beroepsbeoefenaren worden geen afschriften van verwijs- en ontslagbrieven c.q. overdrachtformulieren aan de patiënt verstrekt. Patiënten vragen ook niet om copieën. Dit kan komen omdat de patiënt brieven en overdrachtformulieren mee kan nemen naar huis waar hij ze kan lezen. Het duurt immers een bepaalde tijd voordat hij de brief of het formulier bij een 
volgende afspraak hoeft af te geven.

Toch lijkt deze veronderstelling niet waarschijnlijk aangezien patienten, zoals reeds eerder is opgemerkt, geen behoefte hebben aan inzage.

\section{* Correctie, aanwulling, verwijdering en vernietiging van gegevens}

Volgens het Voorontwerp geneeskundige behandelingsovereenkomst en de Wet persoonsregistraties kan de patiënt een (schriftelijk) verzoek indienen indien hij gegevens in de verslaglegging wil wijzigen (paragraaf 3.3.6). Zijn verzoek hoeft echter pas binnen 1 jaar (Voorontwerp geneeskundige behandelingsovereenkomst) te worden ingewilligd. Aangezien verwijs- en ontslagbrieven c.q. overdachtformulieren gebaat zijn met een snelle verzending is een dergelijke procedure niet bruikbaar.

Uit de interviews met huisartsen blijkt dat ze de patiënt de mogelijkheid geven om de informatie te corrigeren of aan te vullen. Uiteraard kunnen patiënten alleen van deze mogelijkheid gebruik maken indien ze de brieven kunnen lezen of als de huisarts hen uitwoerig vertelt wat hij opschrijft.

Opmerkingen van de patiënt ten aanzien van de inhoud van de brief hebben betrekking op de te uitvoerige verslaglegging en de toegepaste terminologie. Afhankelijk wan het gezondheidsprobleem (soms is vorige klacht van belang om te vermelden) en eventuele aantekeningen van eerdere verwijzingen zal de brief c.q. overdrachtformulier meer of minder gebaseerd zijn op specifiek voor een bepaalde overdracht verzamelde gegevens. Gegevens die bij de vorige klacht verzameld zijn kunnen voor het nieuwe gezondheidsprobleem ook weer van belang zijn. Specialistenbrieven en ander (eerder) verzameld materiaal kunnen worden meegegeven indien ze betrekking hebben op de huidige klacht (Nederlands Huisartsen Genootschap, 1989).

Blijkens de interviews met artsen worden gegevens meestal gecorrigeerd of overtollige informatie wordt verwijderd. Aanvulling of vernietiging komt blijkens de interviews niet voor. Men zou zich echter voor kunnen stellen dat een patiënt zijn arts verzoekt iets in de brief te schrijven omdat hij het moeilijk vindt om hier zelf, na de overdracht van zorg, met een andere hulpverlener over te praten. Tevens kan worden opgemerkt dat een patiënt na overdracht van zorg, mits geïnformeerd over de inhoud van de brief, zelf gegevens mondeling aan kan vullen. De vragg is dan of deze informatie door de specialist net zo gewaardeerd wordt als de door de huisarts schriftelijk verstrekte informatie.

Eén huisarts geeft aan dat de patiënten zelf kunnen besluiten om de verwijsbrief niet af te geven aan de specialist. Hierdoor zou correctie, anvulling, verwijdering of vernietiging van gegevens niet persé nodig zijn. Een dergelijke werkwijze geeft echter aan dat er sprake is van een communicatiestoornis tussen arts en patiènt. Indien de arts de inhoud van de brief met de patiënt bespreekt en hij open staat voor opmerkingen, zal de patiënt waarschijnlijk niet overwegen om de brief niet af te geven. Overigens heeft de specialist de verwijsbrief nodig omdat deze informatie eem belangrijke bijdrage kan leveren aan de continuïteit van zorg. 
Uit het voorafgaande kan een aantal ondutdelijkheden worden geselecteerd met betrekking tot de wijze waarop met rechten van patiënten omgegaan dient te worden tijdens het overdrachtsproces.

* Onduidelijkheid ontrent de inhoud van de informatie die artsen en verpleegkundigen aan de patiènt dienen te verstrekken bij verwijzing naar en ontslag uit het ziekenhuis.

* Onduidelijkheid omtrent de kennis die bij artsen en verpleegkundigen aanwezig dient te zijn over het werk wan collega's werkzaam in het andere echelon.

* Onduidelijkheid over de wijze waarop artsen en werpleegkundigen kennis kunnen nemen van het werk van collega"s werkzaam in het andere echelon.

* Onduidelijkheid over de inhoud van de professionele informatie-overdracht van artsen en verpleegkundigen (in verband het doelgericht verzamelen en vastleggen van gegevens).

* Onduidelijkheid over de wijze waarop artsen en verpleegkundigen werkzaam in het andere echelon bereikbaar dienen te zijn; onder andere van belang voor overleg bij opname in of ontslag uit het ziekenhuis.

* Onduidelijkheid omtrent de noodzaak van enkele stappen in het overdrachtsproces bij een niet-acute verwijzing zoals:

- het expliciet toestemming vragen aan de patiënt voor de verwijzing;

- het vastleggen van de toestemming van de patiënt in zijn dossier en/of verwijsbrief;

- de informatieverstrekking van de specialist aan de huisarts omtrent zijn beslissing tot opname (zodat de huisarts weet waar hij aan toe is en hij de zorg voor de patiënt over kan nemen);

- de informatie verstrekking van de huisarts aan de wijkverpleegkundige omtrent de opname van de patiënt in het ziekenhuis (zodat de wijkverpleegkundige weet dat patiënt is opgenomen en zij een overdrachtformulier kan opsturen).

* Onduidelijkheid omtrent de noodzaak van enkele stappen in het ontslagproces, zoals:

- de informatie aan de patiènt over het inschakelen van derden en diens toestemmingsvereiste hiervoor;

- de rol van de verpleegkundige bij verwijzing en ontslag;

- het overleg tussen ziekenhuis- en wijkverpleegkundige over noodzaak en mogelijkheden van wijkverpleegkundige zorg en de bestelling van verpleegartikelen;

- het overleg tussen specialist en ziekenhuisverpleegkundigen over de noodzaak en mogelijkheden van wijkverpleegkundige zorg;

- de berichtgeving van de specialist en de ziekenhuisverpleegkundige aan collega's werkzaam in het andere echelon dat een patiënt wordt ontslagen (nadat reeds overeenstemming is bereikt over het ontslag van de patiënt);

- de beslissing over het ontslag;

- het toestemmingswereiste voor ontslag van de patiënt en het vastleggen van deze toestemming in zijn dossier en/of ontslagbrief.

* Onduidelijkheid over de wijze waarop patiënten inzage kunnen krijgen in verwijs- en ontslagbrieven c.q. overdrachtformulieren. 
* Onduidelijkheid over de wijze waarop patienten onjuiste of niet meer relevante gegevens in verwijs- en ontslagbrieven c.q. overdrachtformulieren kunnen verbeteren of verwijderen.

* Onduidelijkheid over de mogelijkheid van de patiënt om gegevens in verwijsen ontslagbrieven c.q. overdrachtformulieren aan de vullen.

Bovenstaande onduidelijkheden zijn in de vorm van stellingen gepresenteerd aan een deskundig panel met de bedoeling na te gaan in hoeverre consensus kan worden bereikt ten aanzien van deze aspecten van het overdrachtsproces. 



\section{OPVATTINGEN VAN DESKUNDIGEN OVER VOORWAARDEN VOOR OVERDRACHT VAN ZORG}

\subsection{Inleiding}

In dit hoofdstuk wordt ingegaan op de opvattingen van deskundigen over overdracht van zorg, die wij met behulp van de Delphi-methode onderzochten. Uit de in hoofdstuk 4 beschreven interviews komt naar voren dat hulpverleners niet geheel volgens het in hoofdstuk 3 beschreven juridische kader handelen. Naar aanleiding van de in hoofdstuk 5 genoemde onduidelijkheden hebben wij besloten om stellingen voor te leggen aan een panel van deskundigen om na te gaan in hoever re consensus kan worden bereikt ten aanzien van bepaalde aspecten van het overdrachtsproces.

$\mathrm{Na}$ een uiteenzetting over doel, voor- en nadelen van de Delphi-methode, wordt kort aangegeven waarom en op welke wijze stellingen zijn ontwikkeld. Vervolgens wordt beschreven op welke wijze de Delphi-methode in dit onderzoek is toegepast en worden de resultaten belicht. In de conclusie wordt, naast inhoudelijk commentaar, aangegeven of de methode bruikbaar is voor het formuleren van voorwaarden voor overdracht van zorg.

\subsection{Delphi-methode}

De Delphi-methode is een ondersteuningsmethode voor gestructureerde meningsvorming via herhaalde terugkoppeling van informatie (Van Houten 1988, p. 5). De methode houdt in dat aan een groep van deskundigen (panel), die anoniem zijn. voor elkaar, in een aantal ronden vragen worden gesteld. De respondenten kunnen kennis nemen van elkaars antwoorden, zonder dat zij met elkaar in contact komen.

Kenmerkend voor de Delphi-benadering is hel iteratieve karakter. Dit will in deze context zeggen, dat het onderzoek een kringloopstructuur heeft en uit verschillende zich voortdurend toespitsende onderzoeksronden bestaat. $\mathrm{Na}$ iedere ronde worden de antwoorden van alle panelleden geanalyseerd, samengevat en teruggerappoteerd aan elk afzonderlijk panellid. Een ander kenmerk is de interactieve benadering: de panelleden wordt niet uitsluitend verzocht uit zichzelf informatie te verstrekken, maar worden via het onderzoek in staat gesteld om te reageren op informatie (Van Houten, 1988, p. 5).

De procedure biedt, naast het voordeel dat geen rekening hoeft te worden gehouden met geografische afstanden, door de anonimiteit een optimale kans op het 
meenemen en verwerken van individuele, eventueel sterk afwijkende meningen van panelleden. In groepsbesprekingen komen die dikwijls onvoldoende tot hun recht. Ook kan "het weten wie welk argument hanteert" op voorhand tot een bijvoorbeeld negatieve reactie leiden. Door de anonimiteit wordt dit zogenaande "haloeffect" voorkomen. Met name dit laatste argument is bepalend geweest voor de keuze van de Delphi-methode. Verwacht werd dat verschillende (beroeps)groepen in het panel elkaars argumenten met een zeker vooroordeel tegemoet zouden treden, waardoor zif niet open zouden staan voor elkaars ideeën.

Naast de voordelen van de Delphi-methode worden in de literatuur ook verschillende nadelen besproken. Er zou minder gelegenheid zijn om van elkaars argumenten te leren dan in een groepsdiscussie (Institute of Medicine 1985). Anonimiteit kan tot gevolg hebben dat men te weinig kritisch nadenkt over de stellingen die men betrekt (Sackman 1975; Brorsson en Wall 1985). Sackman voegt hier nog aan toe dat de vragen in een Delphi-onderzoek vaak vaag en dubbelzinnig zijn. Scheibe. Skutsch en Schofer (1975) hebben aangetoond dat mensen zich laten beïnvloeden door de feedback. Men zou meer zoeken naar conformiteit in plaats van dat men het er echt mee eens zou zijn. Zij bepleiten dan ook om te kijken naar de stabiliteit binnen het groepsantwoord, waarmee wordt bedoeld dat bekeken moet worden in hoeverre panelleden hun mening tijdens het onderzoek herzien.

Tenslotte wordt door sommigen het procedurele keurslijf als belemmerend ervaren (Sackman 1975; Balfoort en Dieleman 1985).

Het Delphi-onderzoek kent vele varianten. Het accent lag oorspronkelijk bij het yoorspellen van de toekomst, doch tegenwoordig kunnen twee hoofdklassen worden onderscheiden: voorspellingsgerichte en ontwerpgerichte toepassingsvormen. In de eerste categorie worden prognoses opgesteld op basis van consensus (inhoudelijke overeenstemming). Bij ontwerpgerichte toepassingsvormen doet de methode dienst als beleidsondersteunend hulpmiddel, als instrument om informatie te structureren en om doelstellingen pragmatisch op elkaar af te stemmen. Niet het voorspellende en beschrijvende, maar vooral het anticiperende en ontwerpende gebruik van de methode staat daarbij voorop (Van Houten 1988, p. 6).

Dit onderzoek draagt het karakter van een ontwerpgerichte toepassingsvorm. Ten eerste omdat de methode dienst doet als beleidsondersteunend hulpmiddel, als instrument om informatie te structureren met betrekking tot de voorwaarden voor overdracht van zorg. Ten tweede omdat het accent hierbij heeft gelegen op de realiteit en niet op het voorspellen van de toekomst (paragraaf 6.4.1). Ten slotte kan een derde kenmerk van de ontwerpgerichte toepassingsvorm worden genoemd, het panel bestaat niet uit een homogene groep deskundigen, maar uit uiteenlopende typen deskundigen: zowel hulpverleners als patiënten en ook juristen en onderzoekers zijn in het panel betrokken (paragraaf 6.4.2). 
Aan het formuleren van woorwaarden voor de overdracht van zorg gaat een expliciteringsproces vooraf, waarbij kriteria en standaarden ontwikkeld worden. In deze benadering is men in feite bezig met eenzelfde activiteit als bij kwaliteitstoetsing: ook daarbij gaat het om het vaststellen van normen (standaarden, kriteria) die zich voor toetsing lenen.

Dit expliciteringsproces omvat een viertal stappen (Donabedian 1982), die kunnen worden toegepast op het onderwerp van studie.

\section{Aangeven welke aspecten bij overdracht van zorg bepalend zijn}

In dit onderzoek is het respecteren van bepaalde rechten van de patient door de artsen en verpleegkundigen bepalend.

\section{Specificeren van deze aspecten}

In hoofdstuk 3 zijn de rechten van patiënten, zoals die in de context van dit onderzoek zijn gehanteerd, gespecificeerd. Vervolgens is via interviews over verschillende overdrachtssituaties in kaart gebracht hoe in de praktijk met deze rechten wordt omgegaan. Hierdoor verkregen wij inzicht in enkele belangrijke knelpunten bij het respecteren van de rechten van de patiënt bij overdracht van zorg. De resultaten van dit deel van het onderzoek zijn in hoofdstuk 4 beschreven en in hoofdstuk 5 is aangegeven wanneer de rechten van patiënten wel of niet worden gerespecteerd bij overdracht van zorg.

\section{Wegen van verschillende aspecten}

Om de aspecten te wegen zijn drie Delphi-rondes uitgevoerd, waarbij aan het panel stellingen zijn gepresenteerd. Bij elke ronde heeft de onderzoeker voorwerk verricht, zoals het bestuderen van relevante literatuur en diepte-interviews. Voor de tweede en derde ronde zijn bovendien de reacties van de panelleden verwerkt.

\section{Grenzen aangeven wanneer de overdracht van zorg wel of niet voldoet aan 'de norm'}

$\mathrm{Na}$ drie Delphi-rondes vormden de stellingen, waarover binnen het panel consensus was bereikt, de uiteindelijke voorwaarden voor overdracht van zorg.

De stellingen over overdracht van zorg kunnen op grond wan de meest logische volgorde worden verdeeld over de volgende aspecten, die ook als zodanig uit de interviews naar voren komen:

- informatie aan de patiënt;

- kennis van elkaars werk;

- professionele informatie-overdracht;

- bereikbaarheid;

- opnameprocedure bij niet-acute verwijzing:

- ontslagprocedure;

- verstrekking hulpmiddelen;

- inzage. 


\subsection{Werkwijze}

Het onderzoek is in vier onderdelen uitgewerkt, te weten:

1. Het aantal en de aard van de Delphi-rondes.

2. De panelselectie en benadering.

3. Werkprotocoll en aandachtspunten voor de Delphi-rondes.

4. Tijdsplanning van de Delphi-rondes.

\subsubsection{De Delphi-rondes}

Er zijn drie Delphi-rondes uitgevoerd. De stellingen hadden betrekking op de voorwaarden voor overdracht van zorg. Hierbij moesten de panelleden achtereenvolgens aangeven:

- mogelijkheden en wenselijkheden;

- verwachtingen en ervaringen;

- waarschijnlijkheden en haalbaarheden.

Voor deze stapsgewijze werkwijze is gekozen om te voorkomen dat panelleden reeds in de eerste in plaats van in de derde ronde aan zouden geven welke ontwikkelingen het meest waarschijnlijk en best haalbaar zouden zijn (van Houten 1988 , p. 12).

De invalshoek van waaruit op de stellingen moest worden gereageerd stond echter alleen in de handleiding vermeld. Uit de vragenlijst zelf kon dit niet worden opgemaakt. Hierdoor zijjn de panelleden mogelijk vergeten om bij het invullen van de vragenlijst op de drie verschillende invalshoeken te letten. Deze veronderstelling werd bevestigd in de argumenten van enkele panelleden bij verschillende stellingen. Om deze reden zall bij de beschrijving van de resultaten en de discussie niet nader op dit onderscheid worden ingegaan.

De panelleden konden in de eerste ronde reageren op een 5-puntsschaal van het Likert-type. Tevens werd hun verzocht om hun keuze te beargumenteren. Bovendien werd hun gevraagd aan te geven of de stelling te generaliseren was voor alle overdrachtsprocessen. Met dit laatste wordt bedoeld dat de stellingen voor elke overdrachtssituatie geldig zijn.

Met de tweede vragenlijst wilden wij meer inzicht krijgen in de verschillende argumenten van de panelleden. Zij kregen derhalve het verzoek aan te geven welke argumenten zij irrelevant en/of ondeugdelijk vonden. Vervolgens werd hun gevraagd te beargumenteren waarom zij het met deze argumenten niet eens waren. Bovendien konden zij nieuwe argumenten aan de lijst toevoegen. Tenslotte werd hen gevraagd de argumenten te ordenen door een 1 te plaatsen bij het argument dat hen het meest aansprak, een 2 bij het daarop volgende argument etc..

Ondat uit de reactie van enkele panelleden naar voren kwam dat de vragenlijst in de tweede ronde te lang was, waardoot de vragen mogelijk niet zo zorgvuldig en volledig zijn ingevuld, is besloten on de vragenlijst in de derde ronde op te splitsen in twee delen. Indien een panellid onvoldoende tijd had om beide lijsten in te vullen, werd hem verzocht om op zijn minst de A-lijst in de vullen. Deze had direct betrekking op de rechten van de patiënt. In de B-lijst werden alleen de stellingen opgenomen die indirect betrekking hadden op de rechten van de patiënt en waarbij de score onder de 50\% lag (panelleden zijn het niet eens met de 
stellingen). De onderzoeker wilde weten of het panel het echt niet eens was met deze stellingen. De panelleden konden beide vragenlijsten op dezelfde manier invullen als de lijst in de tweede ronde.

\subsubsection{De panelselectie}

Bij het samenstellen van het panel is in navolging van Donabedian (1982) met de volgende punten rekening gehouden:

1. De panelleden dienden functioneel betrokken te zijn bij de verpleegkundige of geneeskundige hulpverlening in de intra- of extramurale gezondheidszorg dan wel als patiënt(enfunctionaris) bij deze zorg betrokken te zijn. Gezien de prow bleemstelling van het onderzoek zijn ook enkele onderzoekers en juristen met kennis van het terrein van onderzoek in het panel opgenomen;

2. De panelleden dienden interesse en tijd te hebben voor deelname;

3. De panelleden dienden aan te kunnen geven wat onder wenselijke voorwaarden bij overdracht van zorg kan worden verstaan, rekening houdend met rechten van patiënten. Zij dienden hiervoor enigszins afstand te kunnen nemen van de dagelijkse praktijk.

De volgende vertegenwoordigers zijn in het panel $(n=27)$ opgenomen:

* patiënten(vertegenwoordigers) $(\mathrm{n}=4)$ werkzaam bij het Landelijk patiënten/ consumenten platform, de consumentenbond en door dezen aangedragen patiënten;

* huisartsen $(n=4)$ betrokken bij het beleid of werkzaam in de directe patiëntenzorg, maar ook als hoogleraar verbonden aan een universiteit;

* wijkverpleegkundigen $(\mathrm{n}=4)$ : onder andere werkzaam als staffunctionaris, hoofd wijkverpleegkundige en beleidsmedewerker;

* specialisten $(n=5)$ : onder andere werkzaam in de directe patiëntenzorg, maar ook gepensioneerd of als hoogleraar verbonden aan een universiteit;

* ziekenhuisverpleegkundigen $(n=4)$ : onder andere betrokken bij de directe patiëntenzorg, maar ook werkzaam in beleidsfuncties;

* juristen $(n=3)$ met kennis van het gezondheidsrecht;

* onderzoekers $(n=3)$ bekend met het onderwerp van studie.

De patiënten(vertegenwoordigers) zijn benaderd via patiëntenbelangenverenigingen. De artsen en onderzoekers zijn benaderd naar aanleiding van hun publikaties in vakbladen over samenwerking tussen de eerste en tweede lijn. Soms kreeg ik tips van anderen. Tijdens het organiseren van de interviews was ik in contact gekomen met "verpleegkundigen continuitteit van zorg". Deze verpleegkundigen waren zeer geïnteresseerd in het onderwerp en deskundig op het gebied van samenwerking tussen wijk- en ziekenhuisverpleegkundigen. Verder is contact gelegd met verpleegkundigen die betrokken waren bij samenwerkingsprojecten tussen de eerste en tweede lijn. De juristen waren deskundig op het gebied van gezondheidsrecht, bekend uit de literatuur en soms zelfs betrokken bij samenwerkingsprojecten tussen de eerste en tweede lijn. 


\subsubsection{Tijdplanning}

Dit deel van het onderzoek heeft, inclusief het selecteren van de panelleden, zeven maanden in beslag genomen. De panelleden hadden per ronde ruim twee weken de tijd on de vragenlijsten te beantwoorden. Tenslotte dient te worden opgemerkt dat bij de planning van de Delphi-rondes rekening is gehouden met de vakanties van de panelleden. Zoals uit de tijd-as (schema 6.1) blijkt, vond het Delphi-onderzoek in de zomerperiode plaats. Dit bleek bij navraag onder de panelleden geen probleem te zijn, mede door het feit dat zij in het uiterste geval ongeveer vier weken de tijd hadden om de vragenlijst in te vullen en terug te sturen.

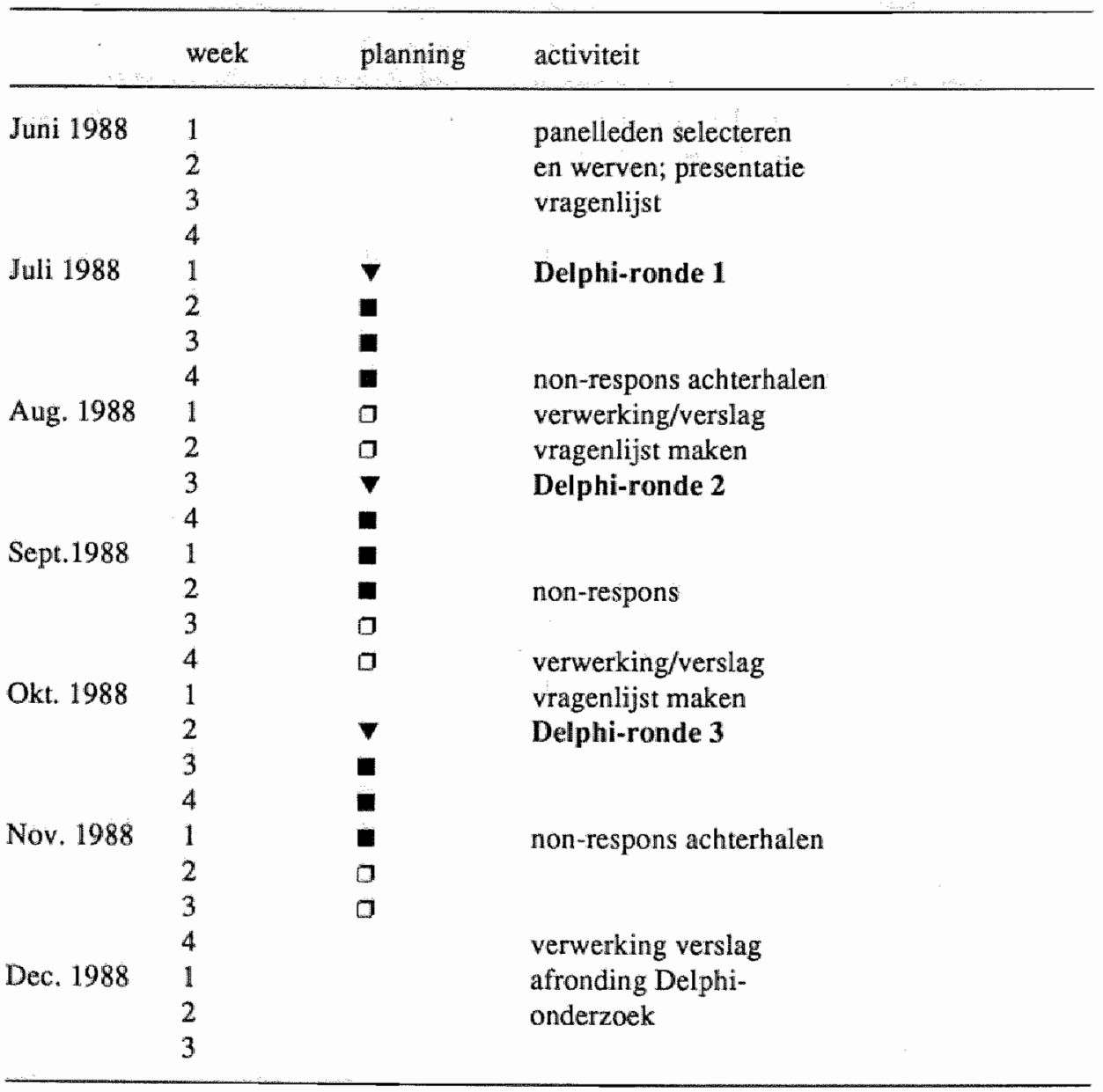

Schema 6.1 Tijdsplanning "Delphi-onderzoek".

$\nabla$ verstuurdatum; $\mathbf{\square}$ beantwoordtermijn; $\square$ uitlooptermijn. 


\subsubsection{Werkprotocol en aandachtspunten}

In het werkprotocol kunnen vier hoofdcategorieën worden onderscheiden, die in verschillende activiteiten uitgewerkt zijn.

\section{Werving panelleden}

De panelleden zijn telefonisch benaderd door de onderzoeker. In alle gevallen werd nadat mondelinge informatie was verstrekt een afspraak gemaakt over deelname in het panel. Hierbij dient te worden opgemerkt dat een aantal panelleden voor dit telefonische contact benaderd zijn door een voor hen bekende medewerker aan de uniwersiteit om hiermee de motivatie tot deelname te verhogen.

\section{Presentatie van de vragenlijst}

De inhoud van de eerste lijst is besproken met een specialist, een huisarts, een verpleegkundige en een onderzoeker, waarbij met name nagegaan werd of de stellingen duidelijk waren. Deze "proefpersonen" namen later niet deel aan het onderzoek.

Voor het ontwerp van de vragenlijst (en later ook voor de presentatie van de resultaten uit de vorige ronde) is gebruikt gemaakt van de ervaring en de deskundigheid van een medewerker van het Medisch en Maatschappelijk Informatiecentrum (MEMIC) aan de Rijksuniversiteit Limburg.

\section{Beantwoording van de vragen}

Zoals uit de tijdplanning blijkt hadden de respondenten voor het invullen van de vragenlijst ruim twee weken de tijd. De mogelijkheid werd aangegeven dat de vragen samen met een collega ingevuld mochten worden. Aan het einde van de tweede week werd telefonisch contact opgenomen met degenen die de lijst nog niet hadden teruggestuurd. In een enkel geval moest al eerder telefonisch overleg plaatsvinden omdat de vragenlijst onduidelijk of onvolledig was ingevuld. Dit persoonlijke contact was mogelijk omdat het panel uit 27 personen bestond. Vooral in de laatste ronde van het onderzoek zijn verschillende panelleden telefonisch benaderd.

\section{Verwerking en verslaglegging}

Om de motivatie onder panelleden te behouden zijn de resultaten binnen een maand teruggekoppeld. De kwalitatief verzamelde gegevens zijn met behulp van de computer uitgewerkt en verwerkt in de volgende vragenlijst. De kwantitatief verzamelde gegevens konden handmatig berekend worden; $\mathrm{zij}$ werden bij de presentatie van de nieuwe vragenlijst zeer beknopt weergeven.

\subsection{De analyse}

De verwerking van de antwoorden was zowel kwantitatief als kwalitatief van aard. Vrij arbitrair is vastgesteld dat over een stelling consensus was bereikt indien 2 van de 3 panelleden het eens waren met een bepaalde stelling $(70 \%)$. 
Bij de kwantitatieve verwerking van de antwoorden is de 5 puntsschaal teruggebracht tot een 3 puntsschaal (eens-neutraal-oneens). Hiertoe is besloten nadat bleek dat de panelleden nauwelijks gebruik hadden gemaakt van de antwoordmogelijkheden "enigszins eens" en "enigszins oneens". In de terugrapportage aan de panelleden werd bij elke stelling de score angegeven. Hierbij werd de volgende indeling gehanteerd:

- score $>70 \%$; stellingen waarover consensus is bereikt;

- score tussen de $50 \%$ en $70 \%$; stellingen waarover het panel niet tot consensus komt;

- score $<50 \%$; stellingen waarover consensus is bereikt; panel is het niet eens met de stelling.

Tevens werd aangegeven of de panelleden vonden dat een stelling te generaliseren was:

Bij de kwalitatieve verwerking zijn alle aanvullingen en argumenten per stelling verzameld en uitgetypt. Dit overzicht werd gebruikt om in een volgende ronde bestaande argumenten te herformuleren en nieuwe argumenten aan de stelling toe te voegen.

\section{* De tweede en derde ronde}

\section{Kwantitatieve verwerking}

Per stelling zijn de volgende handelingen verricht om een antwoord te kunnen geven op de vraag of een meerderheid van het panell $(70 \%)$ het met een stelling eens is:

1. de som vari de argumenten "voor", die de respondent met meest aanspreken

+ eigen argumenten voor

+ de som van de argumenten "tegen" die doot de respondenten niet steekhoudend worden bevonden.

$=$ De totale score die pleit voor een bepaalde stelling.

2. Vervolgens is nagegaan hoeveel belangstelling de respondenten voor een bepaalde stelling toonden door de verschillende handelingen die zij per stelling uitvoerden bij elkaar op te tellen.

De kwalitatieve verwerking en analyse van de gegevens heeft op dezelfde wijze plats gevonden als in de eerste ronde. Aangezien het letterlijk uittypen van de reacties van de tweede ronde zoveel materiaal opleverde dat sprake was van een onoverzichtelijk geheel werd besloten om het verkregen materiaal te comprimeren. Uitvoerige uiteenzettingen werden door de onderzoeker samengevat en vervolgens in de terugrapportage opgenomen.

\subsubsection{Resultaten}

* Globale beschouwing

De respons bedroeg in alle drie de rondes $100 \%(\mathrm{n}=27)$; met uitzondering van de B-vragenlijst in de laatste ronde $(n=26)$. Bij $64 \%$ van de stellingen wordt in de 
eerste ronde reeds consensus bereikt. Naar aanleiding van de resultaten in de eerste ronde zijn enkele stellingen samengevoegd en nieuwe stellingen aan de lijst toegevoegd. De vragenlijst bestond in de tweede ronde uit 120 stellingen. Hierbij wordt bij 78 stellingen (65\%) consensus bereikt (schema 6.2). In de derde ronde komt het panel nog bij een stelling extra tot overeenstemming. Vermeldenswaard is dat het panel bij 15 stellingen $50 \%$ of minder scoort, hetgeen betekent dat het panel het met deze stellingen niet eens is. In schema 6.3 wordt aangegeven waarop deze stellingen betrekking hebben.

Uiteindelijk is het panel het van de 120 stellingen met:

- 79 stellingen eens

- 15 stellingen oneens

Bij 26 stellingen wordt geen consensus bereikt.

Enkele panelleden hebben op grond van de argumenten van de andere panelleden hun mening in de derde ronde herzien. Hierbij moet worden opgemerkt dat het aantal vragen in de derde ronde beperkter was dan in de tweede ronde. Hierdoor nam de aandacht voor de overgebleven stellingen toe. De panelleden hadden de mogelijkheid om hun mening op grond van nieuwe inzichten te herzien. De antwoorden in de derde ronde geven derhalve een meer valide en betrouwbaarder beeld van de meningen van de panelleden dan de antwoorden in de tweede ronde.

Ten aanzien van de generaliseerbaarheid van de stellingen kan worden opgemerkt dat de stellingen die volgens het panel in de eerste ronde te generaliseren zijn, tevens die stellingen blijken te zijn waarover consensus wordt bereikt, in de zin dat de panelleden het met de inhoud eens zijn (schema 6.2). Hierbij gaat het om stellingen die niet direct betrekking hebben op de rechtspositie van de patiènt. Opvallend is dat de meeste aspecten/onderdelen in de verwijsbrief van de huisarts en de ontslagbrief van de specialist te generaliseren zijn.

\subsubsection{Resultaten nader toegelicht}

In het nu volgende worden de resultaten van het onderzoek nader toegelicht. Hierbij zal eerst worden aangegeven over welke stellingen consensus is bereikt, in de zin dat de panelleden het met de stellingen eens zijn (score $>70 \%$ ). Daarna wordt ingegaan op de stellingen waarmee het panel het niet eens is (score $<50 \%$ ) en de stellingen waarover geen consensus wordt bereikt (score tussen de $50 \%$ en $70 \%$ ). $\mathrm{Bij}$ de beschrijving van de resultaten zal worden ingegaan op de argumentatie. Tenslotte dient te worden opgemerkt dat bij de beschrijving van de resultaten geen uitspraken worden gedaan over subgroepen (verpleegkundigen, artsen etc.).

\subsubsection{Stellingen waarover consensus is bereikt (score $>70 \%$ )}

In schema 6.2 wordt aangegeven over welke stellingen de panelleden tot consensus komen. Achtereenvolgens worden de in paragraaf 6.3 genoemde aspecten te weten: informatie aan de patiënt, kennis van elkaars werk, professionele informatie-overdracht, bereikbaarheid, opnameprocedure bij een niet-acute verwijzing, ontslagprocedure, verstrekking hulpmiddlelen en inzage, nader toegelicht. 
Schiema 6.2 Stellingen watrover consensus is bereikt: score $\geq 70 \%$. * stellingen die voor elke overdrachtsuatie geldig zijn.

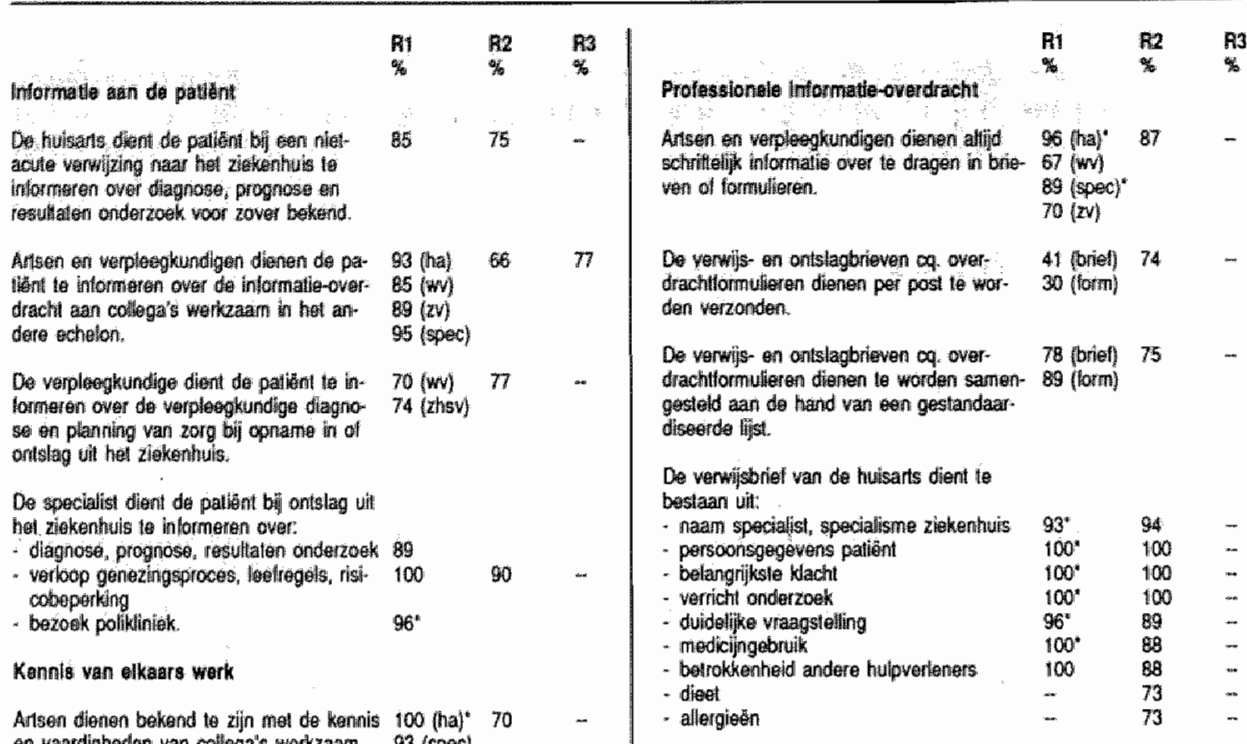

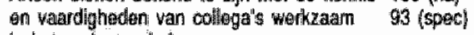
in hiet andere ochelon.

Artsen dienen bekend te zijn mot de moge. iljkheden binnen ziwkenhuiszorg an thuis" 74 (ha) 79 2009 .

Verpleegkundigen dienery bekend te zling

$74(w) 70$ mot de wijze van verzorgen van collega's $B 9$ (zv) workzaam in thet andere echellon.

Varpleagkundigen dienen bukend to zilin meil do aanwezighteid van verplesgartikation bili collega"s werkzaam in het andere ocho. koin.

Andare mogallikhodon voar arsen gn wer:

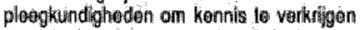
over daskundighoden an kwalltoiten van

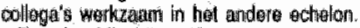

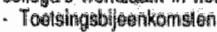

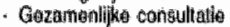

- Gozamenlifita werkgroepen

- Wirkallspraken

- Stages wiknempleagkundigen in hot zio. kankiviss

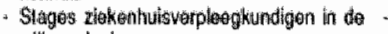
wifkvatploging

- Mezowk huisarts in hot zirkanthuis

- Bezook specialist in de huisat senpraktijk

- Conginessen en studiedtagen

* Persoonlijke contacter

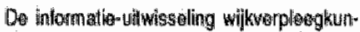
digo-specialisi en huitarts tiekentuiswer.

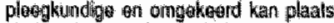
vinden met behulo van koptoen wan wer-

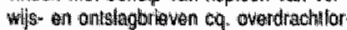
muliesen.

De inhoud van de ontslagbinel wan de spo cialisit dienti: le bestaan ut:

- verricht onderzoek

- Litgowoerde bohandeling

- diagnose an prognoso

- Medicingebru ilk

- botrokkenheid andere hulpwerlaners

- beantwoording vradgstelling huisarts

- (on) riogelijkheden pationnt na ontstang

- worisen lert aanzien van de thuiszorg

- beroek patiönt potlidiniek

- aast palienti verstrekte informatiog (in welhe bewoordingen is informatio varstrekt?

- laakverdeling thutilsarts-specialist

- hulpmiddelen

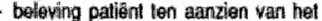
Zieklepuoces

- wie nog mier gatnformeterd mag wrorden

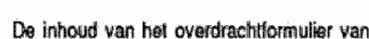
werpleagkndigen diant to bestaan uf

- naam, adres en geboortedatumi

- in we vili zorg einds:

- verplecgkundige antannesso

- venplaugproblemen

- verplengdoelen

- ondemonen adilias

aanpassingen in huis, dieet

- belrokken hulpverteners on rol instellinngan

- mogetijke problemen in die toekons:

- aangevraagde zorg opsiteller owerdrachitionumilier

- baleving van de paliênt ten ajanzizan van thet zilekileproces.

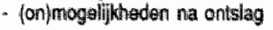

\section{3}

6 
- (oriwasy) wensen pationt

- weinsen then aanzisen vall de thusuzorg

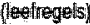

- noodzaals bezoek polikdin

- intentelitarg

Verplegegundinge overdrach wan zorg dien uthstulend domr werplewgkundingen gedaan te wordent.

\section{Berelkbaanheld}

Artisen werpleagkundigen dienen, woof collenglas werkan in hall andere ochelon, bereukbaar la zin op algesproken lijdstipperm.

Artsert wen wogkundigen dienen, woor

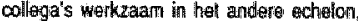

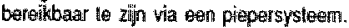

Artsen werpleegkundigen dienen, voor colloga's werhzarm in hell andero ocholon.

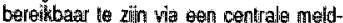
posst.

Opname procedure bil eam nlet-acite verwitizing

De huisiarts dient de palient expliciet too stemririg le wagen voor verwilizing faar hell zilokentuluts.

\section{Ontsilagprocedure}

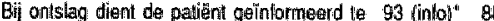
worden over hel ovenliues irschakelen wan 89 floest) terden en hienoor loestemring te geven.
70

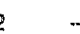

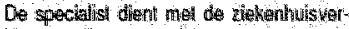

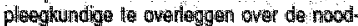

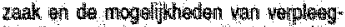

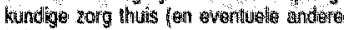
mulp.

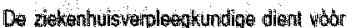

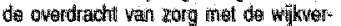
plesgkundige to ow riteggen owor de now

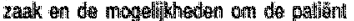
thuts to varplogen an ont arentwala ver. pleogartikelen ta bosiolen.

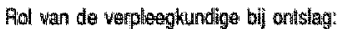

- aqviserende rol

- regelen van piraiktische zalkian

- medistesissisender noll

- reflevante informatio amodragen

De specialist dient do huisarts uhlarlifk 1

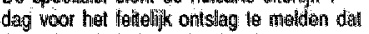
da pationt thuis komt (natial as owereen-

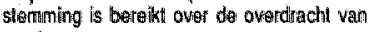
rorg).

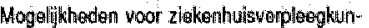

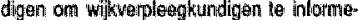
nen dat de palkant thuis kom:

- montaling. tollelonis ch

- sehrifitalink

Inrage

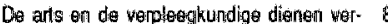
wijs- an onls aglorieven cq. owerdiachtior:

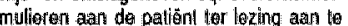
bieden.

De arts en de werpleegkundiga dienern de verwils mulieren to laten lezen op werzoek wan de pationit.

\begin{tabular}{|c|c|}
\hline$\frac{74}{*}$ & $\begin{array}{l}\mathrm{R2} \\
*\end{array}$ \\
\hline 81 & 8 \\
\hline 29 & 缕 \\
\hline$*$ & 100 \\
\hline .. & 95 \\
\hline 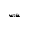 & 88 \\
\hline$-\infty$ & 100 \\
\hline 81 & 96 \\
\hline 78 & 71 \\
\hline$=x$ & 95 \\
\hline 81 & 74 \\
\hline 78 & 87 \\
\hline
\end{tabular}

\section{* Informatie aan de patiënt}

Over de informatie die de huisarts bij verwijzing naar het ziekenhuis aan de patiënt dient te verstrekken over diagnose, prognose en resultaten van onderzoek, zijn de meningen van de panelleden meer verdeeld (R1: 85\%; R2: 75\%), dan over de informatie die de specialist bij ontslag aan de patient dient te verstrekken (R1: diagnose, prognose, resultaten van onderzoek $89 \%$, eventueel bezoek polikliniek $96 \%$, verloop genezingsproces, leefregels en risicobeperking $100 \%$; $\mathrm{R} 2$ : alles bij elkaar 90\%). Aan de ene kant wordt gesteld dat "het geen heilig moeten is" en dat de informatie dient te worden afgestemd op de behoefte van de patiênt. Aan de andere kant erkent men het recht op informatie van de patiënt. Bovendien zou gefaseerde informatieverstrekking het herstel van een patiënt bevorderen en hem in staat stellen keuzes te maken. Over het feit dat informatie de patiënt ongerust kan maken wordt gesteld dat onrust nooit te voorkomen is. 
De verpleegkundige dient de patient te informeren over de verpleegkundige diagnose en planning vatn zorg bij opname in of ontslag uit het ziekenhuis (R3: 77\%). Verschillende panelleden vinden dat de patiênt hier recht op heeft en dat het hoort bij de voorbereiding van de patiënt op de opname en het ontslag. Door enkele panelleden wordt zelfs gesteld dat het verpleegplan in overleg met de patiënt dient te worden opgesteld. Een aantal panelleden vindt deze informatie echter te zwaar; informatie over de verpleegkundige zorgverlening in het algemeen zou voldoende zijjn. Een enkel panellid vindt dat de huisarts de patiênt hierover dient te informeren omdat hij het aanspreekpunt is voor de patiënt.

Artsen en verpleegkundigen dienen de patiënt te informeren over de informatieoverdracht aan collega"s werkzaam in het andere echelon (R3: 77\%). Argumenten hiervoor zouden zijn:

- patiënt moet weten wat over hem verteld wordt/ welke informatie wordt overgedragen, verstrekt in aangepaste bewoordingen;

- patiënt moet weten wie in het bezit zijn gekomen van zijn gegevens;

- recht op privacy van de patiënt;

- patiênt moet kunnen verzoeken om bepaalde informatie niet over te dragen;

- geeft de patiënt de mogelijkheid om zich voor te bereiden op de confrontatie met bijwoorbeeld specialisten en ziekenhuisverpleegkundigen;

- patiënt dient in te stemmen met het verstrekken van vertrouwelijke gegevens aan derden en moet dus op de hoogte worden gebracht van deze informatieoverdracht.

Argumenten tegen:

- professionele informatie-overdracht is niet goed toegankelijk voor de patiënt;

- het verstrekken van de informatie valt onder de verantwoordelijkheid van de hulpverlener.

\section{* Kennis van elkaars werk}

De stellingen die betrekking hebben op het aspect "kennis van elkaars werk" geven enerzijds aan waarover artsen en verpleegkundigen geînformeerd dienen te zijn, anderzijds geven ze aan op welke wijze ze over elkaars deskundigheden en kwaliteiten geinformeerd dienen te worden. In de stellingen wordt geen verband gelegd tussen de inhoud van de informatie en de wijze waarop men over de inhoud geinformeerd dient te worden. Zo is niet expliciet gevraagd op welke wijze de verpleegkundige geïnformeerd moet worden over de aanwezigheid van verpleegartikelen bij collega's werkzaam in het andere echelon. Bij de wijze waarop artsen en verpleegkundigen geìnformeerd dienen te worden wordt steeds gevraagd naar kennis over deskundigheden en kwaliteiten van collega's werkzaam in het andere echelon. Al dekken deze begrippen niet alle aspecten waarover beroepsbeoefenaren geïnformeerd dienen te zijn (bijvoorbeeld kennis over aanwezigheid hulpmiddelen), zij vormen wel een belangrijk onderdeel. Men dient zich echter bij de presentatie van de resultaten te realiseren dat de informatie-uitwisseling op congressen en studiedagen van een andere orde is dan de informatie die beroepsbeoefenaren krijgen tijdens stages, werkbezoeken en persoonlijke contacten. Met name tijdens deze lastste wordt veelal informatie uitgewisseld over een bepaalde patiënt. 
Artsen en verpleegkundigen geven verschillende mogelijkheden aan op welke wijze zij over deskundigheden en kwaliteiten yan collega"s werkzaam in het andere echelon geünformeerd dienen te worden. Informatie over deskundigheden verkrijgt men bij voorkeur via speciaal hiervoor georganiseerde bijeenkomsten/ontmoetingen zoals multidisciplinaire bijeenkomsten of bezoeken wan verschillende beroepsgroepen aan collega's werkzaam in het andere echelon. Hierbij wordt het bezoek van de huisarts aan het ziekenhuis meer gewaardeerd (R2: 86\%) dan het bezoek van de specialist aan de huisartsenpraktijk (R2: $77 \%$ ). Bij verpleegkundigen liggen de percentages ongeveer gelijk; de score voor stages van ziekenhuisverpleegkundigen in de wijk bedraagt $85 \%$ (R2) en die voor de stages van wijkverpleegkundigen in het ziekenhuis $83 \%$ (R2).

Artsen dienen volgens het panel bekend te zijn met zowel de kennis en vaardigheden van collega's werkzaam in het andere echelon (R2: 70\%), als met de mogelijkheden binnen ziekenhuiszorg en thuiszorg (79\%). Interessant is om na te gaan of wijk- en ziekenhuisverpleegkundigen volgens het panel geïnformeerd dienen te zijn over de wijze van verzorgen van collega's werkzaam in het andere echelon. Hierover komt men tot consensus (R2: $70 \%$ ). Kennis over de aanwezigheid van verpleegartikelen in het andere echelon vindt men echter belangrijker (R2: 81\%).

Schriftelijke multidisciplinaire informatie-uitwisseling wordt vooral gezocht in copieën van verwijs- en ontslagbrieven c.q. overdrachtformulieren (R2: $75 \%$ ).

\section{* Professionele informatie-overdracht}

De stellingen die betrekking hebben op de professionele informatie-overdracht hebben enerzijds betrekking op de wijze waarop deze informatie dient te worden overgedragen, anderzijds hebben zij betrekking op de inhoud van de verwijs- en ontslagbrieven c.q. overdrachtformulieren.

Het panel vindt dat artsen en verpleegkundigen de professionele informatie altijd in brieven of formulieren dienen over te dragen (R2: 87\%). Argumenten hiervoor zijn dat deze informatie altijd aanwezig is en gemakkelijk is terug te vinden. Aan de andere kant worden ook twee interessante argumenten tegen schriftelijke informatie-overdracht genoemd: de informatie zou de patiënt blijvend achtervolgen en er zou onvoldoende zorgvuldig met de schriftelijke informatie worden omgesprongen, waardoor de privacy van de patiënt zou worden aangetast.

Het panel is een voorstander van het gebruik van een gestandaardiseerde lijst (R2: $75 \%$ ). Deze zou kunnen worden gebruikt als checklist; bij minder gegevens kan minder worden ingevuld. Bovendien zou het de mogelijkheid geven om methodisch en procesmatig werken te beschrijven. Als tegenargument stelt een panellid dat de samenhang in de informatie verloren zou gaan. Ook zou het creatieve denken worden belemmerd en hierdoor zou informatie vergeten worden.

Over de inhoud van de verwijs- en ontslagbrief en het verpleegkundig overdrachtformulier komt het panel zonder moeite tot consensus. Bijna alle gegevens worden van belang geacht. Een aantal panelleden voelt zich te weinig betrokken bij de zorg om deze vraag te kunnen beantwoorden. Opvallend is overigens dat "de 
informatie die aan de patient is verstrekt" in de verwijsbrief niet zo relevant wordt gevonden als de overige gegevens ( $\mathrm{R} 2 ; 70 \%)$. Bij de aspecten uit het verpleegkundig overdrachtformulier wordt een paar maal de opmerking gemaakt dat de lijst erg uitvoerig is. Hierdoor zou het invullen routinematig gebeuren en zou men nietszeggende informatie krijgen. Gepleit wordt door én panellid om de "standaard-inhoud" te beperken tot een overzichtelijk aantal onderdelen/aspecten.

Het panel vindt dat de verpleegkundige overdracht van zorg uitsluitend door verpleegkundigen gedaan dient te worden en niet door bijvoorbeeld artsen. Argumenten die hiervoor genoemd worden hebben betrekking op de specifieke (verpleegkundige) kennis en vaardigheden waarvoor verpleegkundigen zijn opgeleid. Bovendien zou het de meest rechtstreekse weg zijn waardoor minder informatie-vervorming zou optreden. Een panellid geeft aan dat de arts verantwoordelijk is voor het overdragen van informatie betreffende medische handelingen: de zogenaamde voorbehouden handelingen (toekomstige Wet beroepen individuele gezondheidszorg, art. 53).

\section{* Bereikbaarheid}

Het panel geeft, naast de in de eerste ronde gepresenteerde mogelijkheden, zelf ook aan op welke wijze artsen en verpleegkundigen voor elkaar bereikbaar kunnen zijn. Consensus wordt bereikt over de bereikbaarheid via het piepersysteem (R2: $77 \%$ ), de bereikbaarheid op afgesproken tijdstippen (R3: 76\%) en de bereikbaarheid via een centrale meldpost (R2: $70 \%$ ). Het piepersysteem wordt vooral gewaardeerd om zijn mogelijkheid om elkaar te bereiken in acute overlegsituaties. Bereikbaarheid op afgesproken tijdstippen zou een te beperkte mogelijkheid geven om met elkaar in contact te komen. Het zou wel de communicatie tussen beroepsbeoefenaren bevorderen; zij zouden zich aan moeten passen aan elkaars behoeften. De centrale meldpost heeft het yoordeel dat deze altijd bereikbaar zou zijn. Bovendien zou het als filter kunnen dienen; alleen relevante verbindingen worden tot stand gebracht. Als tegenargument wordt gesteld dat het de persoonlijke cornmunicatie tussen beroepsbeoefenaren zou belemmeren.

\section{* Opnameprocedure bij een niet-acute verwijzing}

Over de verschillende stappen bij de opnameprocedure bij een niet-acute verwijzing komt het panel, met uitzondering van eén stelling, niet tot een consensus. De enige stelling waarover men het eens is, is dat de huisarts de patiënt expliciet toestemming zou dienen te vragen voor de verwijzing naar het ziekenhuis (R2: 92\%). Argumenten hiervoor zijn dat de patiënt bij de behandelling moet worden betrokken; informed consent is een vereiste, de patiënt heeft een eigen verantwoordelijkheid en mening en die zouden door de hulpverlener gerespecteerd dienen te worden. Enkele panelleden stellen dat "de patiënt wel protesteert als hij het niet met de gang van zaken eens is", terwijl andere panelleden zich afvragen wat het toestemming vragen aan de patiënt voor nut heeft als toch een belangrijk deel van de patiènten geen nee durft te zeggen.

\section{* Ontslagprocedure}

Binnen het panel bestaat consensus over het feit dat de patiënt geïnformeerd dient te worden over het eventueel inschakelen van derden en hiervoor toestemming 
dient te geven (R2: 88\%). Als argumenten worden genoemd dat de patient recht heeft op deze informatie. Het zou hem stimuleren in zijn zelfzorg en door de informatie zou hij minder snel voorstellen afwijzen. Als tegenargument wordt gesteld dat de patiënt onvoldoende inzicht zou hebben in de reden waarom een derde ingeschakeld dient te worden en zou hij voorstellen die vervelend voor hem zijn afwijzen.

Consensus bestaat ook over het feit dat de specialist over de noodzaak en de mogelijkheden van verpleegkundige zorg thuis dient te overleggen (R2: 86\%). De verpleegkundige zou meer inzicht hebben in de mogelijkheden van de patiënt met betrekking tot de Algemeen Dagelijkse Levenswerrichtingen (ADL-functies). Bovendien zou de specialist niet degene zijn die bepaalt of niet-medische hulp moet worden aangevraagd.

Het panel is het eens over het feit dat de ziekenhuisverpleegkundige met de wijkverpleegkundige dient te overleggen over de mogelijkheden om de patiènt thuis te verplegen en over eventuele bestelling van verpleegartikelen (R2 $86 \%$ ). Dit zou de continuitteit van zorg bevorderen. Aan de andere kant stellen enkele panelleden dat eerst met de huisarts zou moeten worden overlegd over de noodzaak van wijkverpleegkundige zorg; andere panelleden zijn het hier weer niet mee eens omdat de huisarts hierin niet de eindbeslissing zou hebben.

De rol van de verpleegkundige bestaat volgens het panel uit verschillende aspecten. "Adviseren" en "relevante informatie aandragen" scoren het hoogst (R2: beide $100 \%$ ). Het "regelen van praktische zaken" scoort ook nog hoog (R2: 95\%). Over het feit dat de verpleegkundige ook een medebeslissende rol heeft, is het panel het wel eens, doch dit aspect scoort het laagst (R2: 88\%). Het panel geeft duidelijk aan dat de verpleegkundige een volwaardig teamlid is. Haar rol wordt van belang geacht omdat ze een ander soort contact heeft met de patiënt, "ze maakt veel meer mee".

Het panel komt tot consensus over het feit dat de specialist uiterlijk een dag voor het feitelijk ontslag dient te melden dat de patiënt thuis komt (R2: 96\%). Een panellid vraagt zich af aan wie dit gemeld zou moeten worden. Bedoeld wordt de huisarts. Het merendeel van de panelleden interpreteert de vraag op deze manier. De panelleden geven aan dat mede door het grote aantal kortdurende opnames, huisartsen niet binnen zo'n korte periode geinformeerd kunnen worden. Toch geeft het merendeel van de panelleden aan dat het een goed streven zou zijn. Enkele panelleden achten deze melding alleen noodzakelijk als nazorg gewenst is.

Als mogelijkheid om de wijkverpleegkundige te informeren over de thuiskomst van de patiënt, scoort de schriftelijke melding het hoogst (R2: 95\%). Mondelinge, telefonische melding is ook mogelijk (R2: 71\%). Panelleden noemen bij de argumentatie dat mondelinge informatie weliswaar het snelst gaat, maar dat schriftelijk materiaal uiteindelijk gewenst is om vergissingen te voorkomen. Telefax kan hierbij een uitkomst bieden. 
De arts en de verpleegkundige dienen volgens het panel verwijs- en ontslagbrieven c.q. overdrachtformulieren te laten lezen op verzoek van de patiënt ( $R 2$ : 87\%). Naast het argument dat de patient recht heeft op inzage wordt gesteld dat inzage de betrokkenheid en de medewerking van de patiènt zou bevorderen.

Ook komt het panel tot consensus over het feit dat artsen en verpleegkundigen verwijs- en ontslagbrieven c.q. overdrachtformulieren aan de patiënt ter lezing aan dienen te bieden (R2: 74\%). De patiënt zou recht hebben op deze informatie en het werd gezien als een uiting van respect.

\subsubsection{Stellingen waarmee het panel het niet eens is (score $<50 \%$ )}

In schema 6.3 wordt aangegeven met welke stellingen het panel het niet eens is. $\mathrm{Zij}$ hebben betrekking op de volgende aspecten: informatie aan de patiënt, kennis wan elkaars werk, professionele informatie-overdracht, bereikbaarheid en opnameprocedure bij een niet-acute verwijzing.

\section{* Informatie aan de patiënt}

Volgens het panel dient de wijkverpleegkundige de patiënt, bij opname in het ziekenhuis, niet te informeren over de wijze van verzorgen in verschillende ziekenhuizen in de regio (R3: 40\%). Argumenten die voor de stelling pleiten geven aan dat deze informatie belangrijk is voor de keuzevrijheid van de patiënt; hij zou beter weten wat hem te wachten staat. Argumenten tegen deze stelling geven aan dat de wijkverpleegkundige deze informatie niet hoeft te verstrekken. Het zou door ziekenhuisverpleegkundigen worden gedaan. Bovendien zou deze kennis bij wijkverpleegkundigen ontbreken. Tenslotte wordt aangegeven dat adviezen van zowel de wijkverpleegkundige als van de huisarts verwarrend kunnen overkomen bij de patiënt.

\section{* Kennis van elkaars werk}

Wijkverpleegkundigen dienen volgens het panel niet bekend te zijn met de wijze van verplegen (bijv. taak- of patiëntgericht verplegen) op de ziekenhuisafdeling (R3: 44\%). Hiervoor worden onder andere als argumenten genoemd dat het voor wijkverpleegkundigen in het algemeen en in de grote steden in het bijzonder, zeer moeilijk zou zijn om deze kennis te achterhalen. Ook zou de keuze van de patiënt, door deze informatie, niet worden beïnloed. Hij zou hier niets van begrijpen en hij zou van te voren niet in kunnen schatten welk systeem prettiger voor hem zou zijn. Als argument vór deze stelling wordt gesteld dat deze kennis van bellang is voor werkcontacten tussen verpleegkundigen; wijkverpleegkundigen zouden weten met welke ziekenhuisverpleegkundige ze contact op zouden moeten nemen.

Informatie over deskundigheden en kwaliteiten van collega's werkzaam in het andere echelon dienen artsen en verpleegkundigen niet te verkrijgen via werwijsen ontslagbrieven c.q. overdrachtformulieren (R2: 50\%). Als argument hiervoor wordt onder andere genoemd dat deze middelen dienen voor de uitwisseling van patiënteninformatie. De werkwijze wan de hulpverlener zou hier slechts indirect uit kunnen worden afgeleid. 
Schema 6.3 Stellingen waarover consensus is bereikt

(parnel is het niet eens met de stellingen), scone $\leq 50 \%$

\begin{tabular}{|c|c|c|c|c|c|c|c|}
\hline & $\underset{81}{R i}$ & $\begin{array}{l}\mathrm{R} 2 \\
\%\end{array}$ & $\begin{array}{l}83 \\
\%\end{array}$ & & Ri & $\begin{array}{l}\mathrm{R} 2 \\
*\end{array}$ & $\begin{array}{l}\text { H3 } \\
\%\end{array}$ \\
\hline Infonmate atan de petient & & & & Bereikboiatheld & & & \\
\hline 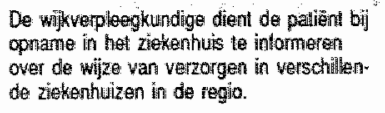 & 81 & 49 & 48 & 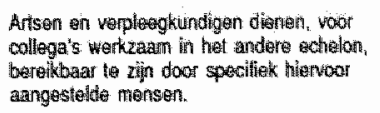 & $\therefore$ & $i$ & 26 \\
\hline Kennis wan elkears werk & & & & 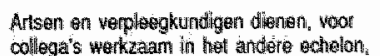 & - & 32 & आ \\
\hline 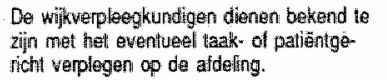 & 85 & 49 & 44 & 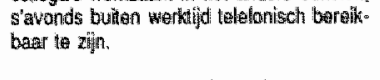 & & & \\
\hline 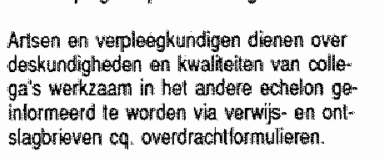 & $\begin{array}{l}44 \text { hal } \\
59(\mathrm{spec}) \\
67(\mathrm{wW}) \\
63(2 \mathrm{w})\end{array}$ & 50 & 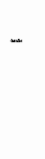 & 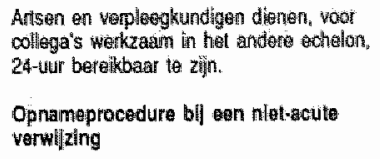 & $-\cdots$ & 46 & 48 \\
\hline 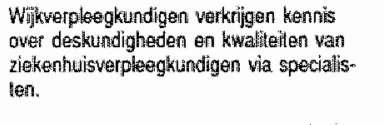 & - & 17 & 15 & 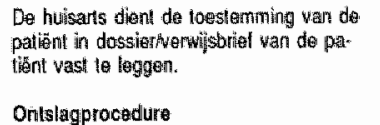 & 52 & 46 & 해낸다. \\
\hline 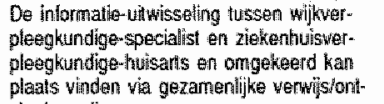 & $\omega$ & 50 & $-\cdots$ & 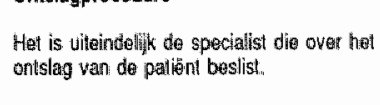 & 52 & 36 & 34 \\
\hline $\begin{array}{l}\text { slaglomilitienen. } \\
\text { Professionele Informatle -overdracht }\end{array}$ & & & & 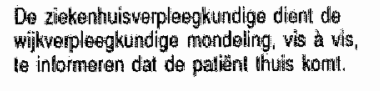 & - & 71 & 19 \\
\hline 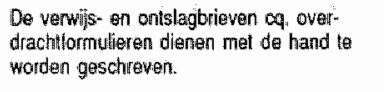 & $\begin{array}{l}11 \text { bret) } \\
22 \text { (tormy }\end{array}$ & 44 & 37 & & & & \\
\hline $\begin{array}{l}\text { De beroepsbeostenaren dienen zich slechts } \\
\text { te baseren op objectieve leiten. }\end{array}$ & 81 & 33 & 44 & & & & \\
\hline $\begin{array}{l}\text { De beroepsbeoetenaren dienen informatie } \\
\text { over derden in de verslaglegging wan de } \\
\text { palienl te wirmijden. }\end{array}$ & 78 & 30 & 34 & & & & \\
\hline 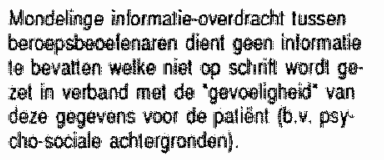 & 33 & 30 & 38 & & & & \\
\hline
\end{tabular}

Het panel geeft aan dat wijkverpleegkundigen niet via de specialist geïnformeerd dienen te worden over kwaliteiten van ziekenhuisverpleegkundigen (R2: 15\%). Argumenten als "betutteling, omslachtig en onnodig" worden hierbij genoemd. Bovendien zou "een extra schakel een vertekening geven van de informatie".

De informatie-uitwisseling tussen wijkverpleegkundige en specialist en ziekenhuisverpleegkundige en huisarts en omgekeerd dient niet plaats te vinden via gezamenlijke verwijs- of ontslagformulieren (R2: $50 \%$ ). Het zou de informatie-uitwisseling vertragen en de bureaucratie vergroten. Aparte formulieren bevorderen dat iedere 
discipline zich verantwoordelijk voelt voor de informatie-overdracht. Als argumenten wóbr de stelling wordt onder andere gesteld dat het gezamenlijk overleg zou bevorderen en hulpverleners van elkaar zouden zien wat en hoe iets gedaan wordt.

\section{* Professionele informatie-overdracht}

Verwijs- en ontslagbrieven c.q. overdrachtformulieren dienen volgens het panel niet met de hand te worden geschreven (R3; 37\%). Een argument is dat de informatie onleesbaar zou zijn.

Het panel vindt niet dat beroepsbeoefenaren zich bij de professionele informatieoverdracht uitsluitend dienen te baseren op objectieve feiten (R3: 44\%). Zo wordt onder andere gesteld dat artsen en verpleegkundigen hun eigen subjectiviteit nooit kunnen uitsluiten. Onder objectieve gegevens verstaat het panel: zichtbare feiten, meetbare gegevens, gegevens die in cijfers zijn uit te drukken en die gebaseerd zijn op professionele normen. Onder subjectieve gegevens verstaat het panel: eigen interpretaties, indrukken, vermoedens en veronderstelligen. Overigens stelt een aantal panelleden dat subjectieve zaken mondeling dienen te worden doorgegeven.

Volgens het panel dient informatie over derden in de verslaglegging van de patiënt niet te worden vermeden (R3: $34 \%$ ). Informatie over bijvoorbeeld mantelzorg wordt (afhankelijk van de context) beschouwd als relevante informatie. Het zou het beeld rondom een patiënt verduidelijken. Bovendien wordt gesteld dat de invloed van derden met name bij ziekte erg groot is. Een aantal panelleden noemt well de voorwaarde dat de patiënt hiervan op de hoogte dient te zijn, een panellid lid vindt bovendien de toestemming van de patiënt voor het vastleggen van gegevens over een derde noodzakelijk.

Het mondeling uitwisselen van informatie, die niet op schrift wordt gezet in verband met de "gevoeligheid" van deze gegevens, wordt door het panel niet afgekeurd ( $R$ 3: 38\%). Mondelinge informatie zou genuanceerder zijn. Het verbieden van mondelinge informatie-uitwisseling zou ten nadele zijn van de patiënt. De patiënt zou worden beschermd door bepaalde informatie niet vast te leggen. Een enkel panellid acht deze gang van zaken in strijd met de privacy van de patiënt.

\section{* Bereikbaarheid}

Artsen en verpleegkundigen dienen niet bereikbaar te zijn via speciaal hiervoor aangestelde mensen (R3: 26\%). Als argument wordt hiervoor gegeven dat een centrale meldpost een beter alternatief is. De 24-uurs bereikbaarheid en de bereikbaarheid buiten werktijd wordt door het merendeel van de panelleden tot niet-reële mogelijkheden gerekend (R3: 30\%).

\section{* Opnameprocedure bij een niet-acute verwijzing}

Het panel vindt niet dat de toestemming van de patiënt voor de verwijzing in het dossier/verwijsbrief van de patiënt dient te worden vastgelegd (R3: 44\%). In de argumenten die pleiten voor de stelling wordt gesteld dat het schriftelijk vastleggen van de toestemming zou thuishoren in het overdrachtsproces en een belangrijk punt zou zijn bij verantwoord handelen. Bovendien zou de 'administratieve belasting' gering zijn. Panelleden stellen daarentegen dat het vastleggen van de toestem- 
ming de communicatie en de werkprocedures zou verlammen. Een panellid associeert het vastleggen van de toestemming met de handtekening van de patient. Volgens hem zou de relatie met de patiènt verzakelijken indien men de patiënt om zijn handtekening zou verzoeken. Het zou bureaucratisch zijn en getuigen van weinig praktisch inzicht. De patiënt zal zelf wel uitmaken of hij wel of niet van de verwijzing gebruik maakt.

\section{* Ontslagprocedure}

Het panel geeft aan dat het niet alleen de specialist is die over het ontslag van de patiënt beslist (R3: 34\%). Als argument wordt hiervoor gegeven dat een patient die ontslag wenst, moet kunnen vertrekken. Enkele panelleden stellen dat overleg met de huisarts nodig is omdat hij de zorg na ontslag moet (kunnen) overnemen en hij de thuissituatie beter kan beoordelen. Als argument vóor de stelling wordt gesteld dat het een medische beslissing is omdat het verblijf van een patiënt in het ziekenhuis berust op een medische indicatie.

De ziekenhuisverpleegkundige dient de wijkverpleegkundige niet mondeling, vis à vis, te informeren dat de patiënt thuis komt (R3: 19\%). Dit zou teveel tijd kosten. Bovendien geeft thet panel de voorkeur aan schriftelijke berichtgeving.

\subsubsection{Stellingen waarover geen consensus wordt bereikt (score tussen de $50 \%$ en $\mathbf{7 0 \%}$ )}

In schema 6.4 wordt aangegeven over welke stellingen het panel niet tot consensus komt. Zij hebben betrekking op de volgende aspecten: informatie aan de patiënt, kennis van elkaars werk, professionele informatie-overdracht, bereikbaarheid, opname procedure bij een niet-acute verwijzing, ontslagprocedure, verstrekking hulpmiddelen en inzage.

\section{* Informatie aan de patiënt}

Het panel bereikt geen consensus over de informatie bij verwijzing van de huisarts aan de patiënt over deskundigheden en persoonlijke kwaliteiten van specialisten en instellingen. Argumenten die voor de stelling pleiten hebben betrekking op de keuzemogelijkheid van de patiënt en de mogelijkheid van de patiënt om zich goed voor te bereiden. Tegenargumenten geven aan dat de huisarts hier onvoldoende inzicht in zou hebben en dat deze kennis een subjectief gegeven zou zijn.

\section{* Kennis van elkaars werk}

De panelleden komen niet tot overeenstemming over de informatie over deskundigheden en kwaliteiten van collega's werkzaam in het andere echelon via refereerbijeenkomsten in de eerste en tweede lijn (R2: 67\%), via de patiënt (R3: $58 \%$ ) of via een brief of folders van vakgroepen over functies en taken (R2: $58 \%$ ). Refereerbijeenkomsten zouden niet motiverend werken en men zou slechts een indruk krijgen van de attitudes van collega's ten aanzien van bepaalde protocollen. De patiënt zou een goede informatiebron zijn om een (subjectieve) indruk te krijgen van de kwaliteit van de arts- of verpleegkundige-patiênt relatie, maar niet zozeer om een indruk te krijgen van technische kwaliteiten van hulpverleners of instellingen. Het panel geeft geen argumenten voor de informatieverstrekking via brief of folders. 
Schema 6.4 Stellingen waarover het panel niet tot consensus komt: score tussen $50 \%$ en $70 \%$

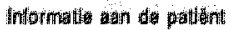

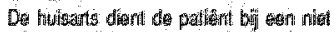

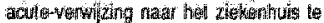
inflorneren ower derskundightedent on per.

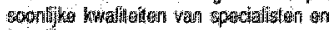
ingut lengert.

\section{Horinis van mkaxime werk}

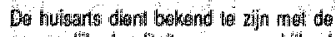

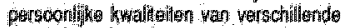

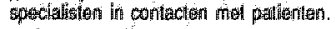

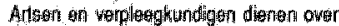

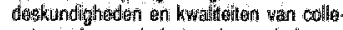

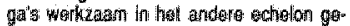

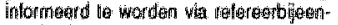
komsigen in het ziekenhuls

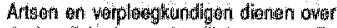

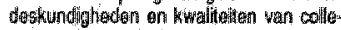

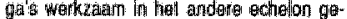

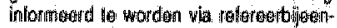
komsten lin de errsite lifin.

Ansen on vitplasglimudigen disner over desikundighodon on kwalineilion van colle. gia's wotkzadm is thet andere echelon gra. intlormend te worden via de palierrit.

Artsen wn verplateghiundigen kunnen over deskundigheder en kwalieiten vas collega's wroraam in thet andere echelon go intormeerd worden via briefifloiders van wakgrosepen over functiosi en taken.

\section{Prolessionete Inionmatio-owerdracht}

De verwijis en ontslagbrineven cq. overdrachilotmulieren dienen door de patièri persoantilitk to worden algelewerd.

De venwilss en ontslagbriaven co. overdrachifformutituren diarien per daki-com-

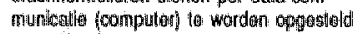
on vertiondan:

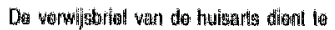
b的新就 㛺:

* vorn van sampenterking

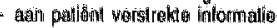

- betrokhentuid pationt

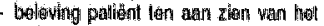
ziekiloppraces

- korte zlaktegeschliodenis

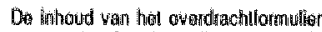

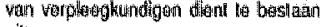
vit:

betrókknonhidd paliènt

- wio nog mear gointormeerd mag wor. den

\begin{tabular}{|c|c|c|c|}
\hline 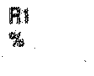 & $\begin{array}{l}\frac{m_{2}^{2}}{2} \\
\%\end{array}$ & $\begin{array}{l}\text { R3 } \\
\% \\
\%\end{array}$ & Berentkaarhild \\
\hline 59 & 6 & - & 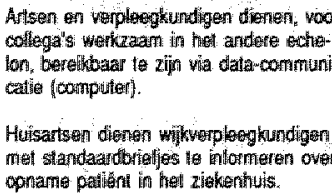 \\
\hline 78 & 62 & $s$ & 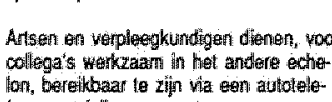 \\
\hline 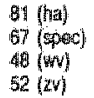 & 67 & $\ldots$ & 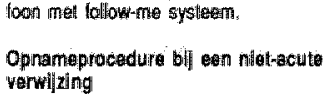 \\
\hline
\end{tabular}

70 that

70 ispac)

$52|w|$

$59(z v)$

33 that

30 (spoc)

37 |wi|

$33(2 v)$

67

Oe spocialist dient de huisarts direct le informeren indien hi: tot de beslissing is gekomen de pationt tan hel zieknenteris op te nement.

De husisarts disent meteen naddal hil weet dal de patient in thell ziekentusisi is opge nomen, de wijkverpleegkundige his rover to inlormenen.

\section{Ontslagprocedure}

De specialis! diend, îndiem hil toil de betsilissing is gokomen dia pationt tra antstatan, dieze hilervor expliciet inestemming te vragen.

De spaciallist dient de lowstemming van de patiént in dossiemiontstagbrival van de patioñ wast le loggen.

3o roriel)

37 (lorm)

64

44 (brial) 48 (form) wijkvenploegkindige for witer ilik 1 dag voor hel feitelijic ontslag to melden dat de pelis nil thuils kont (nadiat al overeanstemining tis bereikt ower de overdrach vain zorg)

\section{Vors trakking fulpmldidellan}

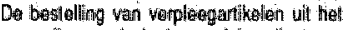
muagaijin wan de kuisweranighing obent

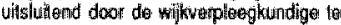
gasselhieden.

\section{lnarage}

De aris en de verplosigkndige dienten de verwits en onlslagktiewen oq. overdrachllontulleven in samenwerkinglowerleg mel die patiênt op to stellein:

63 -. De ats en de verploegkindige dienten op verzoli van de paliunt onjuiste gegewens c. atiot mear rellevanle gergewens in nes-

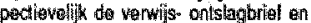
owerdracthtlormulter te veibeleren of te verwijgleren.

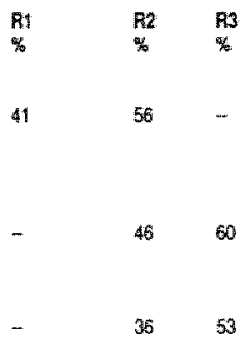




\section{* Professionele informatie-overdracht}

Het panel kiest niet unaniem voor het persoonlijk afleveren van de brieven en formulieren door de patient (R2: 61\%). Aan de ene kant wordt gesteld dat het sneller zou gaan, dat de patiënt minder wantrouwig zou zijn en dat het de betrokkenheid van de patiënt zou verhogen, maar aan de andere kant zou die betrokkenheid een legitimatie zijn voor een situatie die men handig vindt. Ook zou de patiênt de brief kunnen verliezen of vergeten af te geven. Tenslotte wordt gesteld dat de patiënt bepaalde informatie niet zou mogen lezen.

Over het gebruik van de computer voor het verzenden van verwijs- en ontslagbrieven en formulieren wordt eveneens geen consensus bereikt. Naast het argument dat het snelle en overzichtelijke berichtgeving bevordert, wordt gesteld dat het technisch nog niet mogelijk zou zijn en dat de brieven erg stereotiep zouden worden. Bovendien zou de patiënt geen enkel zicht hebben op de gegevens.

Over een vijftal aspecten uit de verwijsbrief van de huisarts wordt geen consensus bereikt: de vorm van samenwerking tussen huisarts en specialist, de aan de patiënt verstrekte informatie, de betrokkenheid van de patiënt, de beleving van de patiënt ten aanzien van het ziekteproces en een korte ziektegeschiedenis. De betrokkenheid en de beleving van de patiënt worden door enkele panelleden gezien als subjectieve gegevens, die tot ongewenste vooringenomenheid van de specialist zouden kunnen leiden. Op de andere aspecten gaat het panel niet in.

Bij het verpleegkundig overdrachtformulier wordt geen consensus bereikt over een tweetal aspecten: de betrokkenheid van de patiënt (R2: 63\%) en wie nog meer geïnformeerd mag worden (R2: 69\%). De panelleden beargumenteren hun keuze niet.

\section{* Bereikbaarheid}

Over de bereikbaarheid via de computer wordt door het panel geen consensus bereikt. Aan de ene kant wordt gesteld dat dit in de toekomst een goed alternatief is, anderzijds wordt geopperd dat het uiteindelijk niet praktisch zou zijn: men zou steeds de computer in de gaten moeten houden. Een aantal panelleden stelt dat soft- en hardware in de eerste en tweede lijn op elkaar dienen te worden afgestemd en dat voorwaarden moeten worden gesteld ter bescherming van de privacy van de patiènt.

Over de informatie-uïtwisseling tussen huisarts en wijkverpleegkundige omtrent de opname van een patiënt in het ziekenhuis wordt evenmin consensus bereikt ( $\mathbb{R} 3$ : $60 \%$ ). De panelleden lichten hun keuze verder niet toe. Eén panellid stelt dat standaardbriefjes een alternatief vormen.

Over het gebruik van een autotelefoon met follow-me systeem komt het panel niet tot overeenstemming (R3: 53\%). Panelleden geven de voorkeur aan het piepersysteem, de centrale meldpost en de bereikbaarheid op afgesproken tijdstippen (schema 6.2). 


\section{* Opnameprocedure bij een niet-acute verwijzing}

Het panel komt niet tot consensus over het feit dat de specialist de huisarts dient te informeren zodra hij heeft besloten de patiënt in het ziekenhuis op te nemen (R2: 65\%). Aari de ene kant wordt gesteld dat de huisarts van opname op de hoogte kan zijn als hij de patiënt verwijst, aan de andere kant wordt gesteld dat de hüisarts zo snell mogelijk geînformeerd dient te worden, zodat hij weet dat hij "zijn begeleidingstalk" kan uitoefenen. Zeker bij een afwijkende diagnose wordt deze informatie van belang gevonden, mede door het feit dat de familie vaak op de huisarts zal terugvallen. Door een aantal panelleden wordt de mogelijkheid genoemd om de huisarts binnen een week te informeren.

Over de berichtgeving door de huisarts aan de wijkverpleegkundige omtrent de opname van cen patiënt in het ziekenhuis wordt geen overeenstemming bereikt (R3: 63\%). Enkele panelleden vinden preventief huisbezoek door de wijkverpleegkundige aan achtergebleven familieleden zinvol. Derhalve dient de huisarts, indien hij problemen verwacht, de wijkverpleegkundige omtrent de opname van de patiënt in het ziekenhuis, te informeren. Als tegenargument wordt gesteld dat de huisarts hier niet toe in staat zou zijn, ondat hij zelf hierover niet of te laat wordt ingelicht. Enkele panelleden geven aan dat de ziekenhuisverpleegkundige de wijkverpleegkundige kan informeren. "Ook wordt gesteld dat de patiënt zelf of zijn familie de wijkverpleegkundige kan informeren.

\section{* Ontslagprocedure}

Het panel bereikt geen consensus over de vraag of de toestemming van de patiënt voor het ontslag vereist is (R3: 66\%). Volgens een aantal panelleden is de hotelfunctie secundair ten opzichte van de medische indicatie; de specialist dient derhalve te bepalen of de patiënt ontslagen kan worden. Aan de andere kant wordt gesteld dat het vragen van toestemming de patiënt de mogelijkheid geeft om zijn opvattingen zelf kenbaar te maken: "niet elke patiènt is zo assertief om te vertellen dat het thuisfront klaar is voor ontslag".

Ook over het vastleggen van de toestemming voor het ontslag wordt geen consensus bereikt (R3: 55\%). Argumenten die onder andere genoemd worden voor het vastleggen van de toestemming zijn: het geeft duidelijkheid en het is een kleine moeite. Als tegenargument wordt gesteld dat de patiënt niet in staat zou zijn om een goede inschatting te maken van het moment van ontslag. Ook zou de specialist zich later kunnen beroepen op het feit dat de patiënt zelf toestemming heeft gegeven, terwijl deze zijn toestemming baseert op de informatie van de specialist. Overigens wordt door enkele panelleden wel gesteld dat in de verslaglegging altijd moet worden vermeld of de patiënt tegen medisch advies in het ziekenhuis verlaat.

Het panel komt niet tot consensus over het feit dat de ziekenhuisverpleegkundige de wijkverpleegkundige uiterlijk een dag voor het feitelijk ontslag dient te melden dat de patiènt thuis komt $(\mathrm{R} 3 ; 68 \%)$. Het zou in dit geval een goede voorbereiding zijn op het ontslag van een patiënt en inzicht geven in de mogelijkheden van de thuiszorg. Verschillende panelleden stellen echter dat voor de voorbereiding meer tijd nodig is; het tijdstip waarop de wijkverpleegkundige geïnformeerd dient te worden zou afhankelijk zijn van de acties die de wijkverpleegkundige moet onder- 
nemen. Slechts enkele panelleden beschouwen de bevestiging van het ontslag van een patiënt als zinvol.

\section{* Verstrekking hulpmiddelen}

Het panel bereikt geen consensus over het feit dat eventueel thuis benodigde verpleegartikelen uitsluitend door de wijkverpleegkundige dienen te worden bestelä (R2: 63\%). In de eerste ronde had de vraag betrekking op hulpmiddelen in plaats van verpleegartikelen. Voor de duidelijkheid is in tweede instantie voor ver-

pleegartikelen gekozen. Argumenten die pleiten voor deze stelling geven onder andere aan dat andere hulpverleners vaak onvoldoende op de hoogte zijn van wat er in het magazijn - de opslagruimte bij een kruisorganisatie - aanwezig is. Bovendien zou het de continuilteit van de verpleegkundige zorg bevorderen. Als tegenargument wordt onder andere gesteld dat dit overleg via de huisarts zou moeten verlopen, vanwege zijn coördinerende functie. Ook zou de wijkverpleegkundige niet altijd ingeschakeld worden, terwij] wel verpleegartikelen nodig zijn.

\section{* Inzage}

De panelleden komen niet tot consensus over het opstellen van verwijs- en ontslagbrieven c.q. overdrachtformulieren in samenwerking/overleg met de patiënt (R3: 59\%). Naast een aantal argumenten die pleiten vóór de stelling, zoals het vergroten van de betrokkenheid van de patiënt, het voorkomen van wantrouwen bij de patiënt, het voorkomen van fouten en de mogelijkheid tot het verwerken van ideeën van de patiënt in de verslaglegging, worden ook een aantal tegenargumenten gegeven. Het zou niet te realiseren zijn door tijdgrebrek. Bovendien zou de verslaglegging onder de verantwoordelijkheid vallen van artsen en verpleegkundigen; het betreft informatie-uitwisseling tussen collega's, waar de patient niet bij betrokken zou hoeven te worden. Het wordt immers gezien als resultaat van het overleg tussen hulpverlener en patiënt.

Het panel bereikt geen consensus over het zogenaamde correctierecht (R3: 65\%). Een argument tegen de stelling is dat de mening van de patiënt naast die van de arts of verpleegkundige kan worden vastgelegd. Ook zou het moeilijk zijn om te bepalen wat juiste informatie is. Aan de andere kant wordt gesteld dat degene die de brief opstelt en tekent de verantwoordelijkheid draagt voor de juistheid van de gegevens.

\subsection{Conclusies}

In deze paragraaf worden conclusies getrokken ten aanzien van de verkregen resultaten, de opvattingen van het panel ten aanzien van rechten en plichten en de bruikbaarheid van de Delphi-methode.

\subsubsection{Conclusies ten aanzien van de resultaten}

Uit het voorafgaande kunnen verschillende conclusies worden getrokken. Aangezien dit onderzoek zich richt op de rechten van de patiënt bij overdracht van zorg, beperken we ons in deze paragraaf tot die stellingen die direct betrekking hebben op de rechtspositie van de patiënt. De stellingen die indirect betrekking hebben op 
de rechtspositie, wormen veelal een voorwaarde om met bepaalde rechten op correcte wijze on te kunnen gaan. Bijvoorbeeld, als de wijkverpleegkundige vindt dat ze niet over bepaalde kennis dient te beschikken, dan kan ze deze kennis ook niet overdragen aan de patiënt.

\section{* Stellingen waarover consensus wordt bereikt}

Over een aantal stellingen die direct betrekking hebben op de rechtspositie van de patient komt het panel tot consensus. Hiervan heeft een aantal betrekking op de informatieverstrekking aan de patiënt. De huisarts dient de patiënt bij een nietacute verwijzing naar het ziekenhuis te informeren over diagnose, prognose en resultaten van onderzoek. De specialist dient de patiënt bij ontslag op zijn beurt te informeren over diagnose, prognose, resultaten van onderzoek, verloop van het genezingsproces, leefregels, risico en bezoek polikliniek. De verpleegkundige dient de patiënt bij verwijzing en ontslag te informeren over de verpleegkundige diagnose en planning van zorg. De wijkverpleegkundige dient de patiënt bij opname in het ziekenhuis niet te informeren over de wijze van verzorgen in verschillende ziekenhuizen in de regio.

Ten aanzien wan de professionele informatie-overdracht komt het panel over een aantal stellingen tot consensus. Artsen en verpleegkundigen dienen de patiënt te informeren over de informatieoverdracht aan collega's werkzaam in het andere echelon. Bovendien dienen zij de informatie altijd via verwijs- en ontslagbrieven c.q. overdrachtformulieren over te dragen, gebruik makend van een gestandaardiseerde lijst. Over het merendeel van de onderdelen van deze lijst wordt eveneens consensus bereikt. Hierbij hoeven artsen en verpleegkundigen zich niet alleen te baseren op objectieve feiten en hoeven zij geen informatie over derden te vermijden. Het mondeling overdragen van "gevoelige gegevens" wordt door het panel niet afgekeurd.

Voor de verwijzing dient de huisarts de patiënt expliciet toestemming te vragen. Deze toestemming hoeft echter niet in het dossier of de verwijsbrief van de patiënt te worden vastgelegd.

Bij het ontslag - waarover overigens niet alleen de specialist besluit - dient de patiënt geïnformeerd te worden over het eventueel inschakelen van derden en hiervoor toestemming te geven.

Tenslotte dienen artsen en verpleegkundigen verwijs- en ontslagbrieven c.q. overdrachtformulieren te laten lezen op verzoek van de patiënt of deze ter lezing aan de patiënt aan te bieden.

Samenvattend kan worden gesteld dat de stellingen waarover consensus wordt bereikt voor een groot deel aansluiten bij het juridisch kader zoals in hoofdstuk 4 is uiteengezet. Dit geldt in mindere mate voor de stellingen die betrekking hebben op het overdragen van schriftelijke informatie over niet alleen objectieve feiten, het mondeling overdragen van "gevoelige gegevens" en het opnemen van informatie over derden in de verslaglegging van de patiënt. 
Het merendeell van de stellingen waarover geen consensus wordt bereikt, heeft slechts indirect betrekking op de rechtspositie van de patient. Ten aanzien van de stellingen die direct betrekking hebben op de rechten van de patiernt kan het volgende worden geconcludeerd.

Het panel komt niet tot consensus over de volgende elementen:

* de informatieverstrekking door de huisarts bij verwijzing over deskundigheden en persoonlijke kwaliteiten van specialisten en instellingen;

* het feit dat de toestemming van de patiènt voor ontslag vereist is en dat deze dient te worden vastgelegd in de verslaglegging;

* het opstellen van verwijs- en ontslagbrieven c.q. overdrachtformulieren in samenwerking/overleg met de patiënt;

* het verbeteren of verwijderen van niet-relevante gegevens in brieven en formulieren op verzoek van de patiënt.

Kortom, de stellingen waarover het panel niet tot consensus komt zijn voor een groot deel niet in strijd met het juridisch kader. Dit geldt niet voor de mogelijkheid van de patiënt om gegevens te verbeteren en/of te verwijderen. Wettelijk heeft de patiënt hier wel recht op, al zou bij verschil in mening de rechter moeten oordelen. Eventueel zou een verklaring van de patiënt aan de brieven en/of formulieren van de patiënt kunnen worden toegevoegd.

\subsubsection{Opvattingen van het panel ten aanzien van rechten en plichten}

In de medische praktijk zijn geluiden te beluisteren dat de arts-patiënt relatie in toenemende mate juridiseert. Niet alleen betreft dat wetenschappelijk onderzoek (o.a. Vandenbroucke 1990), maar ook de individuele patiëntenzorg (van der Mijn 1972). Deze geluiden worden in dit onderzoek niet bevestigd. Het panel vindt de beschreven rechten en plichten blijkbaar acceptabel. Dit komt mogelijk enerzijds door de panelselectie, anderzijds door de inhoud en de functie van de stellingen. Ten aanzien van het eerste punt kan worden opgemerkt dat het panel bestaat uit deskundigen ten aanzien van overdracht van zorg; voor het merendeel beroepsbeoefenaren in de gezondheidszorg. Mogelijk heeft binnen deze groep een zekere acceptatie van juridische normen plaatsgevonden. Met andere woorden, de panelleden hebben ingezien dat georganiseerde structuren onmisbaar zijn om de gezondheidszorg maatschappelijk te laten functioneren. Dergelijke structuren kunnen volgens Leenen (1981, p. 79) zowel beklemmend als bevrijdend zijn. Zij bevrijden als zij ordenen en verdelen, zodat de chaos wordt beperkt en rechtvaardigheid wordt betracht. Tegelijkertijd beklemmen zij, omdat iedere ordening beperking inhoudt, afdamming van (individuele) mogelijkheden.

In de tweede plaats kan worden gesteld dat de resultaten van het Delphi-panel zich beperken tot de opvattingen ten aanzien van de stellingen. Zo kunnen de opvattingen van de beroepsbeoefenaren afwijken van hun werkwijze in de praktijk. Enerzijds omdat beroepsbeoefenaren in het onderzoek sociaal wenselijke antwoorden kunnen hebben gegeven, anderzijds omdat zij in de praktijk aan de ontwikkelde voorwaarden kunnen vergeten te voldoen of moeite hebben met de naleving. Dit onderzoek beperkt zich tot het formuleren van voorwaarden/normen. In volgend onderzoek verdient het aanbeveling na te gaan of in de praktijk aan de in dit 
onderzoek geformuleerde voorwarden wordt voldaan. Indien hiervan wordt afgeweken zall moeten worden onderzocht wat hiervan de reden is.

Tevens kan worden opgemerkt dat in de stellingen niet alleen de zelfbeschikking en de autonomie van de patiënt centraal staan, maar dat ook aandacht wordt geschonken aan het principe van een soepele en continue samenwerking tussen beroepsbeoefenaren die werkzaam zijn in de intra- en extramurale gezondheidszorg. De stellingen zoals in dit onderzoek geformuleerd bieden beroepsbeoefenaren een kader waarbinnen zij zich kunnen bewegen. Niet alleen de patiënt, maar ook de beroepsbeoefenaar is met dergelijke voorwaarden gediend.

Het ontwikkelen van voorwaarden voor overdracht van zorg die onder andere gebaseerd zijn op de rechtspositie van de patiënt, lokt de reactie uit dat hierdoor het "overdrachtsproces gejuridiseerd wordt". In dit onderzoek is geen sprake van uitbreiding van wetgeving, maar van toespitsing van bestaande rechten en plichten in (toekomstige) wettelijke regelingen op het overdrachtsproces. Kritiek kan bestaan op wettelijk regelingen ten aanzien van de rechten van patiënten in het algemeen. Leenen (1981, p. 105) merkt over de uitbreiding van wetgeving - als een aspect van het juridiseringsproces - op dat deze voortvloeit uit het feit dat de maatschappelijke organen op vele terreinen van dat handelen niet of te laat eigen regelingen hebben getroffen, respectievelijk deze regelingen onvoldoende bindende kracht hebben gekregen dan wel onvoldoende in de openbaarheid functioneren. Daarbij komt hij tot de conclusie dat overheden, beroepsbeoefenaren en gezondheidszorginstellingen veellal hun positie in wettelijke regelingen hebben weten te verankeren. Hij stelt: "Merkwaardigerwijs zijn het soms degenen die zelf hun juridische positie hebben weten veilig te stellen, die het bezwaar van juridisering aanvoeren als het gaat om de rechten van de patiënt waarvan de regeling in een eerste fase verkeert. De juridisering - ook buiten het wettelijk kader - heeft vooral aan de aanbodzijde plaats gehad en niet ten aanzien van de positie van de patiënt" (Leenen 1988, p. 155).

\subsubsection{Conclusies ten aanzien van de Delphi-methode}

De Delphi-methode in het onderzoek naar voorwaarden voor overdracht van zorg is met succes toegepast, dit mede dankzij een maximale medewerking van de panelleden . Dit wijst op een grote betrokkenheid bij en interesse in het onderzoek. De methode is bruikbaar gebleken voor het formuleren van voorwaarden voor overdracht van zorg. Reeds in de eerste ronde wordt bij meer dan de helft van de stellingen consensus bereikt. In de daarop volgende rondes kregen de panelleden de mogelijkheid om hun opvatting te herzien en te nuanceren. Enkele panelleden hebben op grond van de argumenten van de andere panelleden hun eigen mening herzien. Hierbij moet worden opgemerkt dat het aantal vragen in de derde ronde beperkter was dan in de tweede ronde. Hierdoor nam de aandacht voor de overgebleven stellingen toe. De antwoorden in de derde ronde geven derhalve een meer valide en betrouwbaarder beeld van de meningen van de panelleden over een stelling dan de antwoorden in de tweede ronde. De scores over de verschillende rondes zijn redelijk constant hetgeen betekent dat de opvattingen van de panelleden zijn uitgekristalliseerd en een vierde ronde niet noodzakelijk wordt geacht. 
Kan men concluderen dat de Delphi-methode bruikbaar is geweest voor het formuleren van voorwaarden voor owerdracht van zorg? In de literatuur worden de volgende factoren genoemd die consensusontwikkeling - een proces tot het al of niet bereiken van overeenstemming (Van Everdingen 1988, p. 11) - ongunstig kunnen be beînvloeden (Sackman 1975; Pauker 1986; Van Everdingen 1988, Enzing 1988; Van Houten 1988):

- wetenschappelijke gegevens worden selectief gebruikt;

- men baseert zich op ervaringen en vooroordelen;

- het eindprodukt komt soms tot stand onder grote tijdsdruk;

- niet-experts hebben een geringe inbreng, terwijl ze wel afhankelijke zijn van het gekozen standaard/protocol;

- dominante leden kunnen hun mening doordrukken.

Van bovengenoemde nadelen hebben wij in dit onderzoek niet veel gemerkt. De panelleden konden zich niet uitsluitend baseren op eigen ervaringen en (voor)oordelen, maar moesten tevens reageren op argumenten van anderen. Hierdoor werd hun blikveld mogelijk vergroot en was er bovendien geen sprake van selectief gebruik van wetenschappelijke gegevens. Het panel bestond uit respondenten die allen vanuit een eigen positie/functie deskundig waren op het gebied van rechten van de patiënt bij overdracht van zorg. Er was geen sprake van niet-experts. Dit was - naast de anonimiteit - mede de reden waarom dominante leden niet in staat waren hun mening door te drukken. Bovendien konden de respondenten binnen de 2 à 3 weken respons-tijd net zoveel tijd uittrekken om de vragenlijst in te vullen als zij mogelijk en/of nodig achtten. Ook konden zij hun mening in de verschillende rondes geleidelijk, niet onder druk, bijstellen. Een dergelijk werkwijze biedt hiervoor meer ruimte dan consensus-bijeenkomsten tijdens discussiedagen, conferenties, symposia of workshops die met hetzelfde doel worden opgezet. Dit komt met name panelleden ten goede, die niet zoveel ervaring hebben in het mondeling presenteren en verdedigen van standpunten. 


\section{BESCHOUWING, CONCLUSIES EN AANBEVELINGEN}

\section{$7.1 \quad$ Beschouwing}

In dit proefschrift is beschreven op welke wijze voorwaarden zijn ontwikkeld voor overdracht van zorg, rekening houdend met rechten van patiënten. Alvorens hier conclusies aan te verbinden moeten enkele relativerende opmerkingen worden gemaakt ten aanzien van de gehanteerde onderzoeksmethodiek en de reikwijdte van de resultaten.

In de eerste plaats zijn de interviews gehouden rondom een beperkt aantal casus, waardloor wij geen generaliserende uitspraken kunnen doen over de feitelijke kenmerken van het overdrachtsproces in het algemeen. Aangezien de patienten wijkverpleegkundige zorg moesten hebben gekregen na ontslag uit het ziekenhuis, zijn alleen patiënten ouder dan 65 jaar in het onderzoek betrokken. Daardoor hebben de resultaten uit de interviews niet meer dan een signalerende functie. Als ondanks deze beperkingen behalve uit de interviews met patiënten ook uit die met andere betrokkenen uit de casus - waarin vooral werd gesproken over opvattingen en ervaringen bij overdrachtsituaties die niet specifiek betrekking hadden op een bepaalde patiënt - de resultaten steeds in een bepaalde richting wijzen, lijkt toch een redelijk betrouwbaar beeld van het owerdrachtsproces te ontstaan.

Tevens kan worden opgemerkt dat niet alle fases binnen het kwalitatieve onderzoek zijn doorlopen. Wij hebben ons beperkt tot een analyse-in-eerste-instantie (Maso 1987, p. 83). Dit wil zeggen dat we alle kennis die wij hadden verworven tijdens het formuleren van de probleemstelling en onderzoeksopzet, evenals de gedachten die we tijdens het verzamelen van de gegevens, tussen haakjes hebben gezet. In de analyse-in-tweede-instantie wordt gebruik gemaakt wan de kennis die de analyse-in-eerste-instantie tussen haakjes is gezet en van de kennis die deze laatste analyse heeft opgeleverd. Maso (1987, p. 115) maakt hierbij een onderscheid in de kennis die niet bestaat uit theorieèn - meningen - en de kennis die daaruit wel bestaat - theorieën. De stappen binnen deze analyse zijn in dit onderzoek niet gezet, aangezien wij - gezien de vraagstelling - niet geinteresserd waren in een theoretische verklaring voor de verschillende verschijnselen. Bovendien leent het normatief juridisch kader zich niet voor een dergelijke analyse. Met de analyse-in-eerste-instantie hebben wij een bevredigend - zij het niet volledig inzicht verkregen in opvattingen en ervaringen van patiënten en hulpwerleners ten aanzien van het overdrachtsproces.

In de tweede plaats kunnen een paar kritische opmerkingen worden gemaakt ten aanzien van de stellingen in het Delphi-onderzoek. Omwille van de lengte van de vragenlijst zijn in de tweede ronde enkele stellingen vit de eerste ronde samenge- 
woegd. Ook zijn om dezelfde reden meer aspecten zoals bijvoorbeeld informatie en toestemming in én stelling opgenomen. Ook al werd hier alleen toe overgegaan nadat bleek dat het percentage voor de afzonderlijke stellingen in de eerste ronde ongeveer even hoog was, geeft het toch een minder zuiver en genuanceerd beeld. Aan de andere kant zouden de panelleden een zeer lange vragenlijst mogelijk niet of minder zorgvuldig hebben ingevuld.

Een tweede kritische opmerking ten aanzien wan de stellingen betreft de wijze waarop panelleden de stellingen interpreteerden. Zo gaven panelleden aan dat de huisarts de wijkverpleegkundige alleen diende te informeren omtrent de opname van een patiënt in het ziekenhuis, als zij bij de zorg van desbetreffende patiënt betrokken was. Bij het formuleren van deze stelling gingen wij al van deze veronderstelling uit, maar dit kwam niet in de stelling tot uitdrukking. Dit lijkt op een onzorgvuldigheid, doch uit de argumentatie van de panelleden begrepen wij op welke wijze de stelling werd geinterpreteerd. Dit leildde overigens niet tot herformulering van de stelling, doch tot aanvulling van de argumenten. Er waren namelijk ook panelleden die vonden dat de wijkverpleegkundige ook geïnformeerd diende te worden als zij nog niet bij de zorg betrokken was, om bijvoorbeeld een preventief huisbezoek te verrichten bij een thuis achtergebleven hoogbejaarde echtgenote die in het dagelijks leven hulp kreeg van haar man, die nu in het ziekenhuis lag. Door de stelling met de aangepaste argumenten opnieuw aan de panelleden aan te bieden verkregen wij een meer valide en betrouwbaarder beeld van de opvattingen van de panelleden ten aanzien van deze stelling.

Onafhankelijk hiervan is nog een derde beperking, het feit dat de resultaten verkregen met de Delphi-methode de mening weergeven van 27 panelleden. Of hun mening wordt aanvaard door andere beroepsgenoten is weliswaar aannemelijk, maar is nog niet bewezen.

\subsection{Conclusies}

De bedoeling van dit onderzoek was het verkrijgen van inzicht in de voorwaarden voor overdracht van zorg, rekening houdend met de rechtspositie van de patiënt. We menen hierin grotendeels geslaagd te zijn. Bij de Delphi-methode vormden de in de interviews gesignaleerde knelpunten en het juridisch kader de basis voor de verschillende stellingen, die zijn gepresenteerd aan een selecte groep deskundigen. De stellingen waarover consensus is bereikt kunnen worden beschouwd als de voorwaarden, die in de praktijk volgens het panel gehanteerd dienen te worden bij overdracht van zorg. Een aantal hiervan heeft direct betrekking op de rechtspositie van de patient. De stellingen die indirect betrekking hebben op de rechtspositie, vormen veelal een voorwaarde om met bepaalde rechten op correcte wijze om te kunnen gaan.

Verwacht werd dat de controverse tussen de meningen van de panelleden groot zou zijn gezien de resultaten uit de interviews, die onduidelijkheid te zien geven omtrent bepaalde aspecten in het overdrachtsproces, en gezien het feit dat het panel bestond uit deskundigen met verschillende achtergronden en belangen. Reeds 
in de eerste ronde bleek deze veronderstelling niet geheel juist; over meer dan de helft van de stellingen werd consensus bereikt, in die zin dat de panelleden het met deze stellingen eens waren. Hiervan heeft een aantal direct betrekking op de rechtspositie van de patiënt:

* de informatie bij verwijzing verstrekt door de huisarts over diagnose, prognose en resultaten van onderzoek;

* de informatie van artsen en verpleegkundigen over de informatie-overdracht aan collega's werkzaam in het andere echelon;

* de informatie van de verpleegkundige over de verpleegkundige diagnose en planning van zorg bij opname in of ontslag uit het ziekenhuis;

* de informatie van de specialist over diagnose, prognose, resultaten onderzoek, verloop genezingsproces, leefregels, risicobeperking, bezoek polikliniek;

* het toestemmingsvereiste voor verwijzing naar het ziekenhuis;

* de informatie over en het toestemmingsvereiste voor het inschakelen van derden bij ontslag uit het ziekenhuis;

* de mogelijkheid tot inzage op verzoek van de patiënt zelf of na voorstel van de arts of verpleegkundige.

Deze stellingen sluiten aan bij het juridisch kader zoals weergegeven in hoofdstuk 3. Hierbij dient te worden opgemerkt dat in de stelling over de inhoud van de informatie van een verpleegkundige bij overdracht van zorg, meer dan in het juridisch kader het geval is, wordt ingegaan op verschillende aspecten waaruit deze informatie kan bestaan.

Er zijn ook stellingen die direct betrekking hebben op de rechtspositie van de patiënt en waarover de panelleden wel tot consensus komen, maar in de zin dat zij het niet met de stellingen eens zijn. Deze gaan met name in op de professionele informatie-overdracht. De panelleden zijn het eens met het feit dat:

* beroepsbeoefenaren zich bij professionele informatie-overdracht niet alleen hoeven te baseren op objectieve feiten;

* zij informatie over derden in de verslaglegging niet hoeven te mijden;

* de mondelinge informatie-overdracht ook mag bestaan uit gegevens die in verband met de "gevoeligheid" van deze gegevens niet op schrift worden gezet;

* de toestemming van de patiënt voor de verwijzing niet in het dossier/de verwijsbrief van de patiënt hoeft te worden vastgelegd.

In tegenstelling tot de vorige stellingen sluiten de eerste 3 stellingen niet geheel aan op de rechtspositie van de patiënt zoals deze in het juridisch kader is weergegeven. Dit betekent dat deze opvattingen niet tot norm kunnen worden verheven; normatieve regels kunnen niet onderzoeksmatig worden afgeleid uit de feitelijkheid.

Tevens komt het panel tot de conclusie dat de wijkverpleegkundige de patient niet dient te informeren over de wijze van verzorgen in verschillende ziekenhuizen in de regio. Deze opvatting is niet in strijd met het juridisch kader.

De stellingen die direct betrekking hebben op de rechtspositie van de patiënt, maar waarover het panel niet tot consensus komt, gaan over: 
* de informatie van de huisarts over deskundigheden en persoonlijke kwaliteiten wan specialisten en instellingen:

* het toestemmingsvereiste yoor ontslag uit het ziekenhuis;

* het vastleggen van deze toestemming in het dossier/de ontslagbrief van de patiënt;

* het in overleg met de patiënt opstellen van verwijg- en ontslagbrieven c.q. overdrachtformulieren;

* de mogelijkheid tot correctie of verwijdering van onjuiste of niet meer relevante gegevens in respectievelijk de verwijs- en de ontslagbrief en het overdrachtformulier.

De eerste vier stellingen komen niet in het juridisch kader terug. Dit geldt niet voor de stelling omtrent de mogelijkheid tot correctie of verwijdering van bepaalde gegevens. De patiënt heeft hier wel wettelijk recht op, al zou bij verschil van mening de rechter moeten oordelen.

Ten aanzien van de informatie van de huisarts over deskundigheden en persoonlijke kwaliteiten van specialisten en instellingen kan worden gesteld dat de patiënt deze informatie nodig kan hebben bij het kiezen van een bepaalde specialist. Het vragen van toestemming van een patiënt bij ontslag uit het ziekenhuis en het vervolgens vastleggen van deze toestemming is weliswaar niet wettelijk vastgelegd, maar kan worden beschouwd als een goede gewoonte. Bovendien geeft het blijk van een systematische afhandeling van zaken. Het ontbreken van toestemming van de patiënt dient op zijn minst vermeld te worden.

Het in overleg met de patiënt opstellen van verwijs- en ontslagbrieven c.q. overdrachtformulieren lijkt van minder belang indien de informatie als resultaat kan worden beschouwd van het overleg tussen arts/verpleegkundige en patiënt en indien de patiënt geïnformeerd wordt over het doel en de inhoud van de professionele informatie-uitwisseling. Deze werkwijze hoeft een snelle verzending van de informatie niet te belemmeren.

De mogelijkheden en beperkingen van deze geformuleerde voorwaarden voor overdracht van zorg betreffende, dient men zich te realiseren dat ze in algemene zin zijn opgesteld, dat ze nog niet binnen de verpleegkundige en geneeskundige beroepsgroep als consensus-richtlijnen zijn aanvaard en dat er altijd omstandigheden zijn die een bijzondere aanpak vereisen. Ook kan de arts of de verpleegkundige bij een bepaalde patiënt afwijken van de richtlijn. Zij moeten dit dan wel beargumenteren en vanzelfsprekend dient de keuze in overleg met de patiënt te worden gemaakt.

\section{3}

\section{Aanbevelingen}

De nu volgende aanbevelingen zijn gerangschikt naar aanbevelingen voor volgend onderzoek en aanbevelingen ten aanzien van de implementatie van de resultaten van dit onderzoek.

Bij onderzoek verdient het aanbeveling om alvorens tot een Delphi-methode over te gaan, eerst te onderzoeken op welke wijze inzicht kan worden verkregen in de dagelijkse praktijk, in al zijn gevarieerdheid. In dit onderzoek is om verschillende 
redenen gekozen woor het bestuderen van wet- en regelgeving, jurisprudentie en zelfregulering in combinatie met het houden van diepte-interviews rondom verschillende casus. Gezien de grote tijdsinvestering in verhouding tot het verkregen inzicht in de dagelijkse praktijk bij overdracht van zorg, dienen andere methoden worden overwogen c.q: te worden toegepast en onderzocht. Hierbij kan in ieder geval worden overwogen om de casus-benadering los te laten, ondanks de in dit onderzoek genoemde woordelen van deze selectie van onderzoekseenheden.

Zoals reeds in het vorige hoofdstuk is opgemerkt is onderzoek gewenst naar de wijze waarop in de praktijk met de in dit onderzoek geformuleerde voorwaarden door beroepsbeoefenaren wordt omgegaan. Indien van de voorwaarden wordt afgeweken, moet worden onderzocht wat hiervan de oorzaak is.

Verder dient in volgend onderzoek te worden nagegaan welk effect de resultaten hebben in de dagelijkse praktijk, opdat meer inzicht wordt verkregen in de werkelijke betekenis van consensusmethoden. Een dergelijk evaluatie-studie zou kunnen bestaan uit enquêtes gericht aan betrokkenen en een analyse van beleidsplannen, richtlijnen en adviezen van verschillende organisaties.

Ten aanzien van de implementatie van de resultaten uit dit onderzoek kan worden opgemerkt dat op grond van de stellingen waarover consensus is bereikt een begin kan worden gemaakt met het verbeteren van het overdrachtsproces. In dit onderzoek is aangegeven in hoeverre de mening van het panel afwijkt van het juridisch kader. Hieruit blijkt dat de patiënt - omdat hij hier wettelijk recht op heeft - toch de mogelijkheid dient te krijgen om onjuiste gegevens c.q. niet meer relevante gegevens in respectievelijk verwijs- en ontslagbrief en overdrachtformulier te verbeteren of te verwijderen. In een volgend onderzoek kan een stelling met een dergelijke strekking gepresenteerd worden aan een deskundig panel, met het verzoek aan te geven op welke wijze dit aspect allsnog in het proces kan worden opgenomen.

In het laatste deel van dit onderzoek zijn opvattingen gevraagd van een multidisciplinair panel, waardoor een mengeling plaatsvindt van verschillende waarden en normen. Het lijkt gerechtvaardigd te veronderstellen dat de bereikte consensus niet direct gehoor zal vinden in een bepaalde beroepsgroep, bijvoorbeeld artsen. De resultaten uit dit onderzoek kunnen echter wel als basis worden gebruikt om door middel van "Delphi-rondes in eigen kring" - waarbij vooral die stellingen gepresenteerd worden die direct betrekking hebben op de betreffende groep - ook specifieke beroepsgroepen te bewegen zich aan te sluiten bij de in dit onderzoek verkregen consensus. De overtuigingskracht van de resultaten zal groter zijn indien de stellingen aan een grote groep praktizerende beroepsbeoefenaren zouden worden aangeboden. Hierbij dient men zich wel te realiseren dat de antwoorden van het panel binnen een korte tijd verwerkt en teruggekoppeld dienen te worden om de interesse onder panelleden voor het onderzoek te behouden. Vooral de analyse en terugkoppeling van de argumenten van panelleden kost veel tijd.

Het verdient aanbeveling om de resultaten van dit onderzoek onder betrokkenen in de dagelijks praktijk bekend te maken en ter discussie te stellen. Hiervoor is niet alleen publikatie in de vakbladen nodig, maar dienen betrokkenen ook zoveel 
mogeijijk op andere wijze te worden bereikt. Hierbij kan gedacht worden aan het informeren van functionarissen die de samenwerking in de eerste- en tweede lijn coördineren, zoals functionarissen belast met ondersteuning van huisartsen, coördinatoren eerstelijnsgezondheidszorg, werpleegkundigen continuiteit van zorg, coördinatoren van diagnostische centra en beleids- en stafmedewerkers in ziekenhuizen en patièntenorganisaties. 


\section{LITERATUUR}

Aghina, M.J., Patiëntenrecht, een kwestie van gewicht, Assen/Amsterdam, Van Gorcum, 1978.

Balfoort, C., Dieleman $\mathrm{H}$., Waarde en rol van methoden bij onderzoeksprogrammering, RAWB, serie achtergrondstudies (nr.12), Den Haag, 1983.

Beleidsadviescollege Automatisering Gezondheidszorg, Advies inzake privacy- en gegevensproblematiek, Leidschendam, 1985.

Beugeling, A., Wouden, J.C., van der, De verwijsbrief in zijn context, Medisch. Contact, 44, 1989, blz. 873-876.

Beusekom, J.H.H., van, Geerling, J., De ontslagbrief. Nederlands Tijdschrift voor Geneeskunde, 132, 1988, blz. 2315-2316.

Bins-Vunderink, N., Patiëntenorganisaties, Tijdschrift voor gezondheidsrecht, 3, 1979, blz. 102-106.

Bleeker, H., Mulderij, K., Pedagogiek op je knieën, Aspecten van kwalitatiefpedogogisch onderzoek, Boom, Meppel/Amsterdam, 1984.

Brauw, P.J.W. de, Kalkman-Bogerd, L.E., Rechtspraak Medisch Tuchtrecht 19761987, Serie Gezondheidsrecht nr.21, Kluwer, Deventer, 1988.

Brorsson B., Wall S., Assessment of medical technology, Problems and methods. Medicinska Forskingsradet, Swedisch Medical Research Council, 1985.

Bijl, N.P.Y.M. de, Betrokkenheid van de patiënt bij de zorg in thet ziekenhuis, in: Mur, I.M., (red.), Patiëntenzorg onderzocht: naar een betere afstemming van vraag en aanbod, Congresbundel IWZ symposium, De Tijdstroom, LochumGent, 1988, blz. 101-109.

Bogdan, R.C., Biklen, S.K., Qualitative research for education, an introduction to theory and methods, Allyn and Bacon, Boston, 1982.

Busschbach, J.T., Verhaak, P., Patiëntenvoorlichting bekeken, Gezondheid en Samenleving, 8, 1987, blz. 11-22.

Casparie, A.F., Gestructureerde samenwerking, Medisch Contact, 40, 1985, blz. 97100.

Centrale Raad voor de Volksgezondheid, Deeladvies betreffende de juridische relatie tussen patiënt en arts, het recht van de patiënt op informatie en het toestemmingsvereiste, Rijswijk, 1980.

Centrale Raad voor de Volksgezondheid, Deeladvies inzake de bescherming van de privacy van de patiënt, Rijswijk, 1981,

Centrale Raad voor de Volksgezondheid, Deeladvies inzake medische experimenten met mensen, Rijswijk, 1982.

Centrale Raad voor de Volksgezondheid, Deeladvies inzake de bemiddeling bij klachten bij patiënten, Rijswijk, 1982.

Centrale Raad woor de Volksgezondheid, Deeladvies inzake kernbepalingen voor de regeling van de relatie tussen patiënt en arts, Rijswijk, 1982.

Commissie Structuur en Financiering Gezondheidszorg, Bereidheid tot verandering, Den Haag, 1987. 
Couper, MAR., The Delphi technique: characteristics and sequence model, Advances in nursing science, 1984 , blz. $72-77$.

Dekkers, A.F.M. De patient en het recht op informatie (diss.), Excerpta Medica, Amsterdam, 1980 .

Denzin, $_{*}$ N.K., The research act: a theoretical introduction to sociologocal methods, McGraw-Hill, New York, 1970.

Donabedian A. The criteria and standaards of quality, Arbon, A.N. 1982, blz. 149199.

Enzing, E.M.* Implicaties van biotechnologische ontwikkelingen voor het voortgezet onderwijs op de (middel)lange termijn, Studiecentrum voor Technologie en Beleid-TNO. Apeldoorn, 1988.

Everdingen, J. van, Consensusontwikkeling in de geneeskunde (diss.), Bohn, Scheltema en Holkema, Utrecht, 1988.

Fahrenfort, M., Een doktersroman, een verkenning van de ervaringswereld van arts en patiént op een polikliniek interne geneeskunde (diss.), VU Uitgeverij, Amsterdam, 1985.

Glaser, B., Strauss, A., The discovery of the grounded theory: strategies of qualitative research, Aldine Publishing Co, Chicago, 1967.

Gevers, J.K.M., De rechter en het medisch handelen, Serie Gezondheidsrecht nr.12, Kluwer, Deventer, 1984a.

Gevers, J.K.M., Widdershoven, T.P.J.C., De rechtspositie van de patiënt, inventarisatie van regelgeving, aanbeveling voor onderzoek, Instituut voor sociale geneeskunde, Universiteit van Amsterdam, $1987 \mathrm{~b}$.

Groodman, C.M., The Delphi technique: a critique. Journal of Advanced Nursing $1987,12, \mathrm{blz} .729-734$.

Hageman, H.J., Giffen, H. van, Meyboom, W.A., Verslaglegging van specialist aan huisarts, Medisch Contact, 39, 1984, blz. 513-514.

Have, H.A.M.J. ten, Thung, P.J., Leeuwen, E. van, Beleid, ethiek en waarden in de gezondheidszorg, Nederlands Tijdschrift voor Geneeskunde, 23, 1985, blz. $1102-1105$.

Have, H.A.M.J. ten, Gezondheid en haar wetenschappen, Nederlands Tijdschrift voor Geneeskunde, 29, 1987, blz. 1274-1278.

Houten, H.J. wan, Mogelijkheden en dilemma's van beleidsgericht Delphi-onderzoek. Amsterdam, 1988.

Houten, HJ. van, Vijf variaties op het Delphi-thema, in: Delphi: methode of mode? Daniëls, J.J.M.C, Duijzer, G. SISWO, Amsterdam, 1988.

Hubben, H.J., Psychotherapie en recht (diss.), Ars Aequi Libri, Nijmegen, 1984.

Institute of Medicine, Assessment of medical technologies, Washington DC, National Academy Press, 1985.

Jacobs, H.M., Touw-Otten, F.W.M.M., Melker, R.A. de, Taakopvatting en ziekenhuisbezoek, Huisarts en Wetenschap, 22, 1979, blz. 226-234.

Kastelein, W., Modelregeling arts-patiënt, Medisch Contact, 44, 1989, blz. 527529.

Kaufmann, C.L., Informed Consent and the patient decisionmaking: two decades of research, Social Science and Medicine, 17, 1983, blz. 1657-1664.

Klop, R., Automatisering bij overdracht van zorg, in: Roscam Abbing, H.D.C. (red.), Terugblik en vooruitzien, Vakgroep Gezondheidsrecht, Rijksuniversiteit Limburg, Maastricht, 1987, blz. 103-118. 
Koninklijke Nederlandsche Maatschappiji tot bevordering der Geneeskunst, Gedragsregels voor artsen, Utrecht, 1978.

Koninklijke Nederlandsche Maatschappij tot bevordering der Geneeskunst, Besluit en Rapport inzake Geneeskundige Verklaringen, Intercollegiale Informatie, Medische Informatie, Utrecht, 1982.

Koninklijke Nederlandsche Maatschappij tot bevordering der Geneeskunst, Landelijk Patiënten/ Consumenten Platform, Modelregeling arts-patiënt, Medisch Contact, 44, 1989, blz. 551-555.

Kuiper, J.P., Het zail onze zorg zijn, Inleiding tot de gezondheidkunde, Van Gorcum, Assen, 1975.

Landelijke Specialisten Vereniging der KNMG, De beroepsverantwoordelijkheid en -aansprakelijkheid van de specialist, LSV-informatiereeks, nr.3, 1979.

Leenen, H.J.J., Sociale Grondrechten en Gezondheidzorg, De Boer/Brand, Bussum, 1966.

Leenen, H.J.J., Structuur en functioneren van de gezondheidszorg, Samsom, Alphen aan den Rijn/Brussel, 1981.

Leenen, H.J.J., Rechten van mensen in de Gezondheidszorg, Samsom, Alphen a/d Rijn, 1878.

Leenen, H.J.J., Privacy en de gezondheidszorg, Kwartaaltijdschrift Privacy en Persoonsregistratie, 4, 1983, blz. 47-48.

Leenen, H.J.J., Roscam Abbing, H.D.C., Bestuurlijk Gezondheidsrecht, Samsom/Tjeenk Willink, Alphen a/d Rijn/Brussel, 1986.

Leenen, H.J.J., Handboek gezondheidsrecht, Samsom, Alphen a/d Rijn, 1988.

LeCompte, M.D., Goetz, J.P., Problems of reliability and validity in ethnographic research, Review of Educational Research, 52, 1982, blz. 31-60.

Leininger, M.M., Qualitative research methods in nursing, Grune and stratton inc., Orlando, 1985.

Markenstein, L.F., te Braake, Th.A.M., De patiènt en zijn medische gegevens; een analyse van de jurisprudentie, Vakgroep Gezondheidsrecht, Rijksuniversiteit Limburg, Maastricht, 1985.

Meyboom, W.A., Casparie, A.F., Berichtgeving aan de huisarts bij ontslag wit het ziekenhuis, Medisch Contact, 35, 1980, blz. 989-993.

Melker, R.A. de, Ziekenhuis, huisarts, huisgezin (diss.), Dekker en van der Vegt, Nijmegen, 1973.

Maso, I., Kwalitatief onderzoek, Boom, Meppel, 1987.

Munhall, P.L., Oiler, C.J., Nursing Research, a qualitative perspective, AppletonCentury-Crofts/Prentice-Hall, Norwalk Connecticut, 1986.

Mijn, W. van der, Wetgever en het medisch handelen, Medisch Contact, 1972, blz. 1168.

Nationale Kruisvereniging, Inventarisatie kontinuilteit van verpleegkundige zorg, Bunnik, juli 1985.

Nationale Raad voor de Volksgezondheid, Advies Verpleegkundig Beroepsprofiel, Zoetermeer, 1984.

Nationale Raad voor de Volksgezondheid, Rapport Reacties Verpleegkundig Beroepsprofiel, Zoermeer, 1988.

Nationale Raad voor de Volksgezondheid, Nota bouwstenen voor Beroepscodes en Gedragsregels, Zoetermeer, 1988.

Nooy, A., Meten en wegen, in: L. Brunt, Anders bekeken, Boom, Meppel, 1977. 
Nota Patiëntenbeleid. Tweede Kamer, zitting 1980-1981, 16771, nr.2.

Nederlands Huisartsen Genootschap, De verwijsbrief naar de Tweede lijn, Huisarts en Wetenschap, 3, 1989, blz. 102-105.

Njoo, K.H., Wouden, J.C. van der, Wouterlood-wan Cleef, I.E., Dokter, H.J., Samenwerking tussen huisarts en specialist bij mensen die lijden aan kanker, Medisch Contact, 44, 1989, blz. 994-996.

Oosterhuis, W.W., De communicatieve waarde van correspondentie tussen huisarts en specialist, Medisch Contact, 29, 1974, b]z. 963-964.

Oosterman-Meulenbelt, A.C., De wijkverpleegkundige, "verlengde arm" van de huisarts? Verpleegkunde, 2, 1987, blz. 26-32.

Pauker, S., Decision analysis as a synthetic tool for achieving consensus in technology assessment, International Journal Technology Assessment in Health Care, 2, 1986, blz. 82-87.

Peters, V., Kwalitan, ondersteunend programma bij de analyse van kwalitatieve gegevens, Katholieke Universiteit Nijmegen, 1987.

Philipsen, H., Steekproeven (inaug. rede), Universitaire Pers, Leiden, 1969.

Philipsen, H., Rationaliteit en ons oordeel over de verdwijnende patiënt, Gezondheid en Samenleving, 6, 1985, blz. 142-151.

Philipsen, H., Het deelproject continuiteit van zorg: blauwdruk, Rijkuniversiteit Limburg, Maastricht 1986.

Philipsen, H., Zorgen maken over zorg, Gezond Limburg, 39, 1986, nr.3, blz. 1-7.

Philipsen, H., Gezondheidzorg als project en bejegening, waarden ten aanzien van ziekte, gezondheid en samenleving, Rijksuniversiteit Limburg, Maastricht, 1988.

Pop, P., Keysers, L.L.J.M, Communicatie tussen huisarts en specialist, Medisch Contact, 40, 1985 " blz. 203-206.

Rang, F.F., Patiëntenbeleid (inaug. rede), Leiden, Staffleu, 1973.

Reuling, A., Methodologeën, H. Nelissen, Baarn, 1986.

Rink, J.E., Rijkeboer, J., Bruikbaar onderzoek in de hulpverlening, Wolters-Noordhoff, Groningen, 1983.

Roscam Abbing, H.D.C., Rechten van de patiënt, grondslagen en knelpunten, Acta Hospitalia, 2, 1984, blz. 21-29.

Roscam Abbing, H.D.C., Rechten van patiënten en wettelijke ziektekostenverzekeringen, Tijdschrift voor Gezondheidsrecht, 8, 1984, blz. 161-174.

Roscam Abbing, H.D.C., Onderzoek naar invulling van erkenningseisen Ziekenfondswet/Algemene wet bijzondere ziektekosten, Vakgroep Gezondheidsrecht, Rijksuniversiteit Limburg, Maastricht, 1987.

Roscam Abbing, H.D.C., De rechtspositie van de patiënt en het rapport van de Commissie-Dekker, Tijdschrift voor Gezondheidsrecht, 11, 1987, blz. 404-416.

Roscam Abbing, H.D.C., Rechten van patiënten: individuele en sociale grondrechten in de Gezondheidszorg, in: Beaufort, I., (red.), Handboek Gezondheidsethiek, van Gorcum, Assen/ Maastricht, 1988, blz. 207-216.

Ruhe, H.A.M., De verwijskaart in relatie huisarts-specialist: hoeksteen of obstakel? Medisch Contact, 29, 1974, blz. 769-770.

Sackman H; A Delphi-Critique, Lexington Books, Lexington, Massachucetts, 1975.

Scheibe, M.; Skutsch, M., Schofer, J., Experiments in Delphi Methodology, in: The Delphi-method, techniques ans applications, Linstone H.A., Turoff, M. Addison-Wesley Publ., Massachusetts (USA), 1975. 
Scheuder, R.F., Participatie door en vanuit patiënten, in: Wijmen, F.C.B. van, (red.), Democratisering, Kwartaalschrift Leiding en Organisatie in de gezondheidszorg, 3, Alphen a/d Rijn/Brussel, 1983, blz. 134-166.

Seegers, J.H.G., Sociologische onderzoeksmethoden, Van Gorcum, Assen/Amsterdam, 1977.

Smaling, A., Methodologische objectiviteit en kwalitatief onderzoek, Swets en Zeitlinger, Lisse, 1987.

Smitz, L., Werd u al geholpen? Verpleegkundige overdracht van zorg, De Bevrijding, Amsterdam, 1988.

Stichting Nationale Ziekenhuisraad en Stichting Samenwerkende Landelijke Kruisverenigingen, Informatie rond het thema continuteit van zorg, Utrecht, 1972.

Strauss, A.L., Qualitative analysis for social scientists, Cambridge University Press, New York, 1987.

Swanborn, P.G., Methoden van sociaal wetenschappelijk onderzoek, Boom, Meppel, 1987.

Swinkels, M.M.A., Lodewick, L., Samenwerking tussen huisarts en specialist, een inventarisatie in de regio Gouda, Medisch Contact, 39, 1984, blz. 205-206.

Vandenbroucke, J.P., Medische ethiek en gezondheidsrecht, hinderpalen voor de verdere toename van kennis in de geneeskunde?, Nederlands Tijdschrift voor geneeskunde, 134, 1990, blz. 5-6.

Thomas, W.I., The child in America, New York, 1928, blz. 572.

Tweede Voortgangsnota Patiëntenbeleid, Tweede Kamer, zitting 1987-1988, 16771, nr.31.

Velthuis, F., Boorsma, Y., Communicatie ziekenhuis-thuisfront, Medisch Contact, 36,1981 , blz. 1496.

Voorontwerp geneeskundige behandelingsovereenkomst, 1987.

Warmenhoven, N.E., De rechten van de patiënt, Opvattingen van huisartsen en patiënten, Nivel, Utrecht, 1985.

Warmenhoven, N.E., De rechten van de patiënt, Medisch contact, 40, 1985, blz. 1373-1378.

Wester, F., Strategieën voor kwalitatief onderzoek, Coutinho, Muiderberg, 1878.

Wet persoonsregistraties, Staatsblad 665, 1988.

Wolffers, I., Patiëntenboek, Een handleiding voor patiënten en mensen uit hun naaste omgeving, Amsterdam, Bert Bakker, 1978.

Wouden, J.C. van der, Dokter, H.J., Samenwerking tussen huisarts en specialist bij mensen die lijden aan kanker, Medisch Contact, 44. 1989, blz. 959-961.

Wijshoff-Vogelzang, R.L.M., Arts-patiënt, Enige juridische aspecten in hun relatie (diss.), Serie Gezondheidsrecht nr.14, Kluwer, 1984.

Wijmen, F.C.B., Recht op kwaliteit (inaug. rede), Kluwer, Deventer, 1983.

Wijmen, F.C.B. van, Hoe bijzonder is de rechtspositie van de patiënt? Nederlands Juristen Blad, 60,1985 , blz. 541-548.

Wijmen, F.C.B. van, Juridische aspecten van patiëntenvoorlichting, in: Damioseaux., $V$ en Visser, A. (red), Patiëntenvoorlichting, een interdisciplinaire benadering, Van Gorcum, Assen/Maastricht, 1988, blz. 26-46.

Uzendoorn, H.M. van, Miedema, S., De kwaliteit van kwalitatief onderzoek, Pedagogische Studien, 63, 1986, p.498-505.

Voortgangsnota Patiëntenbeleid, Tweede Kamer, zitting 1982-1983, 16771, nr.14.

Ziekenfondsraad, Modelovereenkomst specialist-ziekenfonds, 1988. 
Ziekenfondsraad, Modelovereenkomst ziekenfonds-huisarts, 1988

Ziekenfondsraad, Modelowereenkomst kruiswerk AWBZ, 1988. 


\section{SAMENVATTING}

In dit onderzoek vormt overdracht van zorg van een patiènt tussen artsen en verpleegkundigen werkzaam in de eerste en tweede lijn onderwerp van studie. Het accent ligt op de wijze waarop daarbij omgegaan wordt met de rechten van de patiënt, zoals privacy, informatie, toestemming, vrije keuze en inzage. Onder overdracht van zorg wordt verstaan, de overdracht van verantwoordelijkheid voor de zorg van een patiënt. Van belang bij dit proces zijn de informatie aan de patiënt en tussen hulpverleners, beslissingen over verwijzing, behandeling, ontslag en nazorg alsmede de vertrouwelijke omgang met persoonsgegevens.

In hoofdstuk 1 worden de aanleiding en de vraagstelling van het gezondheidswetenschappelijke onderzoek gepresenteerd. Enkele oorzaken voor de problematiek rondom overdracht van zorg worden benoemd, zoals de afhankelijkheid van de patiënt, de toename van medische mogelijkheden , de vergrijzing van de bevolking, het substitutiebeleid van de overheid en de specialisering in de gezondheidszorg. Dit onderzoek gaat in op de vraag aan welke woorwaarden het overdrachtsproces, zoals dat plaatsvindt van de eerste naar de tweede lijn en vice versa, moet voldoen. Hierbij vormt het juridisch kader, met in het bijzonder de rechten van de patiënt, het normatief wetenschappelijk uitgangspunt.

In hoofdstuk 2 wordt een methodologische verantwoording van de gekozen overwegend kwalitatieve - onderzoeksopzet gegeven. Het onderzoek bestaat uit de volgende drie delen:

- een literatuurstudie van wet- en regelgeving, jurisprudentie en zelfregulering om inzicht te verkrijgen in de rechtsposistie van de patiënt bij overdracht van zorg;

- interviews met patiënten, artsen en verpleegkundigen om inzicht te krijgen in hun opvattingen en ervaringen ten aanzien wan het overdrachtsproces;

- de Delphi-methode om na te gaan in hoeverre consensus kan worden bereikt over de voorwaarden voor overdracht van zorg.

In hoofdstuk 3 wordt het juridisch kader beschreven, dat grotendeels gebaseerd is op (toekomstige) wetgeving. De reden voor deze keuze is dat wetgeving in deze context beschouwd kan worden als condensatie van rechtsontwikkelingen ten aanzien van de rechten van patiënten an omdat die - in tegenstelling tot jurisprudentie en zelfregulering - beoogt een algemene geldigheid te hebben.

In hoofdstuk 4 worden de resultaten van de interviews gepresenteerd met patienten $(n=11)$, artsen $(n=22)$ en verpleegkundigen $(n=22)$ rondom 11 casus. Hierbij ging het om de de wijze waarop de respondenten over hun ervaringen en opvattingen met het overdrachtsproces zouden praten. Patiënten bleken zich meer te richten op eigen ervaringen, terwijl hulpverleners meer spraken over overdrachtssituaties in het algemeen. De resultaten zijn niet te generaliseren naar een algemeen overdrachtsproces; de interviews vormen slechts een illustratie van de werkelijkheid, zoals wij die in de praktijk aantroffen. 
Verder wordt in dit hoofdstuk ingegaan op de bedreigingen van de validiteit en de betrouwbaarheid en wordt angegeven welke maatregelen zijn genomen om de kwaliteit van de onderzoeksresultaten te bewaken.

In hoofdstuk 5 wordt ingegaan op de resultaten uit de interviews in het licht wan de rechtspositie van de patiënt. Hieruit blijkt dat artsen en verpleegkundigen veelal niet geheel volgens het in hoofdstuk 3 beschreven juridische kader handelen. Dit geldt voor enkele stappen in het verwijs- en ontslagproces, zoals de informatieverstrekking door artsen en verpleegkundigen aan de patiënt en het toestemmingsvereiste, maar ook voor de wijze waarop patiênten inzage kunnen krijgen in verwijsen ontslagbrieven c.q. overdrachtformulieren en hierin gegevens kunnen verbeteren, aanvullen of verwijderen.

In hoofdstuk 6 wordt beschreven op welke wijze de Delphi-methode is toegepast. De resultaten uit het juridisch kader en de interviews zijn in de vorm van stellingen, in drie Delphi-rondes, voorgelegd aan een deskundig panel bestaande uit patiënten $(n=4)$, artsen $(n=9)$, verpleegkundigen $(n=8)$, juristen $(n=3)$ en onderzoekers $(n=3)$. Zij waren allen deskundig op het gebied van de samenwerking tussen de eerste en tweede lijn en/of rechten van patiënten. De stellingen zijn drie maal aan het panel voorgelegd. De resultaten uit iedere ronde werden in de volgende ronde gespresenteerd.

De stellingen - die kunnen worden beschouwd als de voorwaarden voor overdracht van zorg - hadden direct of indirect betrekking op de rechtspositie van de patiënt. Indirecte stellingen vormen voorwaarden om op correcte wijze met de rechten van patiënten om te kunnen gaan. Het panel bleek het na 3 rondes met 97 stellingen eens te zijn en met 15 stellingen oneens. Over 26 stellingen is geen consensus bereikt.

De stellingen waarover consensus is bereikt sluiten voor een groot deel aan bij het juridisch kader. De huisarts dient, volgens het panel, de patiënt bij een niet-acute verwijzing naar het ziekenhuis te informeren over diagnose, prognose, resultaten onderzoek "voor zover bekend. De specialist dient de patiënt bij ontslag uit het ziekenhuis op zijn beurt te informeren over verloop diagnose, prognose, resultaten onderzoek, verloop genezingsproces, leefregels, risico en bezoek polikliniek. De verpleegkundige dient de patiënt bij verwijzing en ontslag te informeren over de verpleegkundige diagnose en planning van zorg. De wijkverpleegkundige hoeft de patiênt bij opname in het ziekenhuis niet te informeren over de wijze van verzorgen in verschillende ziekenhuizen. Zowel artsen als verpleegkundigen dienen de patiënt te informeren over de professionele informatie-overdracht aan collega"s werkzaam in het andere echelon.

Volgens het panel dient de huisarts voor de verwijzing de patiënt expliciet toestemming te vragen. Deze toestemming hoeft echter niet in het dossier of de verwijsbrief van de patiënt te worden vastgelegd. Artsen en verpleegkundigen dienen de professionele informatie altijd via verwijs- en ontslagbrieven c.q. overdrachtformulieren over te dragen, gebruik makend van een gestandaardiseerde lijst. Over het merendeel van de onderdelen van deze lijst wordt eveneens consen- 
sus bereikt. Bovendien dienen artsen en verpleegkundigen verwijs- en ontslagbrieven c.q. overdrachtformulieren op verzoek van de patiènt te laten lezen of deze ter lezing aan de patiënt aan te bieden. Tenslotte dient de patiênt bij het ontslag geïnformeerd te worden over het eventueel inschakelen van derden en hiervoor toestemming te geven.

Drie stellingen blijken niet aan te sluiten bij het juridisch kader. Het panel komt tot de conclusie dat beroepsbeoefenaren zich bij het uitwisselen van informatie over een patiënt niet alleen hoeven te baseren op objectieve feiten. Bovendien dienen zij informatie over derden niet in de verslaglegging te mijden en tenslotte mag informatie welke niet op schrift wordt gezet in verband met de "gevoeligheid" van deze gegevens voor de patiënt mondeling worden overgedragen.

De stellingen waarover het panel niet tot consensus komt, hebben op é́n na, niet direct betrekking op de rechtspositie van de patiënt zoals deze in het juridisch kader is weergegeven. De huisarts hoeft de patiënt bij verwijzing naar het ziekenhuis niet te informeren over deskundigheden en persoonlijke kwaliteiten van specialisten en instellingen. In de literatuur wordt echter aangegeven dat informatie hierover voor de patiënt soms van belang kan zijn om beslissingen te kunnen nemen. De toestemming van de patiënt voor het ontslag is volgens het panel niet vereist.

Verwijs- en ontslagbrieven c.q. overdrachtformulieren hoeven niet in samenwerking/overleg met de patiënt te worden opgesteld. Het panel komt niet tot consensus ten aanzien van de mogelijkheid van de patiënt om niet meer relevante c.q. onjuiste gegevens in de verslaglegging te verbeteren of te verwijderen. De patiënt heeft hier echter wel wettelijk recht op, al zou bij verschil van mening de rechter moeten oordelen.

Ten aanzien van de Delphi-methode kan worden opgemerkt dat deze bruikbaar is gebleken om inzicht te verkrijgen in de voorwaarden voor overdracht van zorg. Van de in de literatuur benoemde factoren die consensus-ontwikkeling ongunstig kunnen beïnvloeden hebben wij in dit onderzoek niet veel gemerkt. De panelleden konden zich niet uitsluitend baseren op ervaringen en (voor)oordelen, maar moesten tevens reageren op argumenten van anderen. Herdoor werd hun bikveld vergroot en was er bovendien geen sprake van selectief gebruik van wetenschappelijke gegevens. Dominante panelleden konden in dit onderzoek niet hun mening doordrukken en alle panelleden hadden de mogelijkheid on zonder tijdsdruk en vooroordelen op elkaars argumenten te reageren.

Tenslotte kan worden opgemerkt dat de in dit onderzoek beschreven voorwaarden voor overdracht van zorg in algemene zin zijn opgesteld, waarbij de rechtspositie van de patiënt als uitgangspunt is genomen. Dit betekent dat, ondanks dat de beschreven voorwaarden binnen de verschillende beroepsgroepen nog niet aanvaard zijn als de voorwaarden voor overdracht van zorg, artsen en verpleegkundigen ze toch als uitgangspunt dienen te hanteren. De arts of verpleegkundige kan bij een bepaalde patiënt afwijken van de richtlijn. Zij moeten dit dan wel beargumenteren en vanzelfsprekend dient de keuze in overleg met de patiënt te worden gemaakt. 


\section{SUMMARY}

This research reports a study of the patient's admission and discharge process as carried out by doctors and nurses working in hospital and in the community. The main Issue is the way in which the patient's rights are respected, such as the right to be informed, the right to consent, the right to a free choice, the right to privacy, and the right to have access to referral and discharge forms and letters.

Admission to and discharge from hospital entails the transfer or assignment of responsibility for the care of a patient. During this process the exchange of information between health care professionals, and to the patient is of importance, as well as the decisions about referral, treatment, discharge and after care. In addition, doctors and nurses will have to treat all information about the patient confidentally.

This study was undertaken from a health sciences point of view. Chapter 1 outlines the rationale of the inquiry and describes the lay-out of this book.

Chapter 2 presents the arguments justifying the research methodology, which is largely of a qualitative nature. The study comprises the following three parts:

- a review of the literature covering professional standards, government directives and jurisprudence in order to obtain an insight in the patient's legal status;

- interviews with patients, doctors and nurses to elicit their views and personal experience with the adrmissiont and discharge process;

- the use of the Delphi technique to generate opinions and arguments on the conditions formulated for the admission and discharge process, with the objective of reaching consensus about these conditions.

Chapter 3 describes the legal framework which is largely based on (future) legislation, since this legislation can be considered as a condensation of the legal trends in the development of patients rights. Contrary to jurisprudence and selfregulation, legislation aims at general validity.

The interviews with patients $(n=11)$, doctors $(n=22)$ and nurses $(n=22)$ are presented in chapter 4 . We were interested in the way respondents would describe their opinions and experiences with the admission and discharge process. Obviously , patients talked about their own experiences, whereas health care professionals were focused on the admission and discharge process in general.

Specific attention is paid to the threats to which the quality of qualitative research is exposed in general and to the enhancement of the reliability and validity of this investigation in particular.

Chapter 5 presents and discusses the results of the interviews in the light of the patient's legal status. The results show that doctors and nurses do not always respect patients' rights as laid down by the law. 
A description of the Delphi technique is given in chapter 6. Propositions were presented to patients $(n=4)$, doctors $(n=9)$, nurses $(n=8)$, jurists $(n=3)$ and researchers $(n=3)$. Similarly, they were all experts on the admission and discharge process and/or patients' rights.

The propositions were presented to the panel three times, the results of the first round being presented in the second round, and so on. The aim was to reach a consensus about the conditions for the admission and discharge process.

The propositions, which can be considered as the conditions for the transfer of care, refer directy and indirecty to the patient's legal status. The indirect propositions can be considered as the conditions relating to the correct observance of a patient"s rights. The experts reached an agreement on 97 propositions after three rounds. They disagreed on 15 propositions, and did not reach consensus on 26 propositions.

The accepted propositions correspond largely to the legal framework. However, there are three areas of disagreement. Firstly, written information may not deal only with objective facts. Secondly, information about third parties may included in the patient's record, and thirdly, "sensitive information" may be given verbally.

In case of an acute referral, the general practitioner should inform the patient about the diagnosis, prognosis and results of the examination so far as is known. In case of discharge from hospital, the specialist should similarly inform the patient about the progress of the relevant illness, prognosis, results of the examination, regimen, risks, and visits to the outpatients' department.

In case of referral and discharge, the nurse should inform the patient about nursing diagnosis and how the care will be executed. In case of referral, the community nurse does not inform the patient about the possible differences in care facilities in hospitals. Doctors as well as nurses will have to inform a patient about the professional exchange of information between colleagues working in hospital and in other ancillary and outpatient services. The general practitioner must explicity ask patient's consent for the referral. It is not necessary to record this consent in the patient's record.

Doctors and nurses should always exchange information by way of referral or discharge letters, and forms using a standard list of items. The experts achieve consensus on the majority of iterns in the list. Doctors and nurses should allow a patient access to the various referral and discharge letters and forms. Finally, a patient should give his/her consent if other health care professionals are called in.

All but one of the propositions where the experts do not reach consensus refer indirectly to the patient's legal status as mentioned in the legal framework. When referring a patient to hospital, the general practitioner does not need to inform the patient about the expert knowledge and personal expertise of specialists and instititionsworking in hospitals. The literature, however, states that the information pertaining to specific expert services may be of importance in the patient's decision-making process. 
In case of discharge, the patient's consent is not needed. Consequently, it is not necessary to record the consent, neither in medical or nursing records, nor in discharge forms or letters. Referral and discharge letters and forms need not be composed in consultation with the patient.

The experts have not reached consensus about the possibility for a patient to change or remove irrelevant or incorrect information from the record. Nevertheless, the patient has the right to do so. In the event of a difference of opinion between patient and health care professional, it is for the courts to decide.

The Delphi technique has proven to be a useful tool to gain insight in the conditions for the admission and discharge process. The experts were not allowed to state their opinions based simply upon their experiences and prejudices, but they had to respond to arguments presented by other members. This has ensured enlargement of their overall view and scientific data could not be used selectively. Dominant members were not able to force their opinion on to others, and all the panel members were allowed to react to the arguments presented.

Finally, the conditions for the transfer of care specified in this study have been formulated in a general way, taking the legal status of the patient as the starting point. This means that doctors and nurses should respect all the propositions formulated, in spite of the fact that the experts have not reached consensus on all of them. A doctor or nurse may have to deviate from a certain condition in a specific case. Should such a case occur, he or she should support his/her opinion with well-defined arguments. It goes without saying that any option decided by the health care professional should be discussed with the patient. 


\section{DANKWOORD}

Ondanks het feit dat ik in de beginjaren van mijn onderzoek het vermoeden had dat mijn dankwoord zich zou beperken tot een enkeling, moet ik nu constateren. dat ik veel meer mensen dank verschuldigd ben.

Om te beginnen mijn twee promotores, professor Frans van Wijmen en professor Hans Philipsen, die mij de mogelijkheid hebben gegeven om een gezondheidswetenschappelijk onderzoek te 'verrichten. Frans, ik realiseer mij dat het niet eenvoudig moet zijn geweest om een niet-jurist te introduceren in het gezondheidsrecht. Mijn oprechte dank voor je geduldige begeleiding. Ik heb het erg gewaardeerd dat je mij hierbij toestond om me vol overgave te verdiepen in kwalitatieve onderzoeksmethoden en deze ook toe te passen.

Hans, met jouw manier van begeleiden leverde je een aanslag op mijn gezonde bestaan. Toch draag ik je een warm hart toe. Het waren vooral de gesprekken over thema's van het onderzoek die zeer verhelderend waren. Je liet een nieuw licht schijnen op alledaagse verschijnselen en bracht je boodschap veelal in een humoristische context.

De leden van de vakgroep Gezondheidsrecht dank ik voor hun collegialiteit. Het was goed toeven in deze deskundige groep. Van het commentaar van Trees te Braake op hoofdstuk 3 heb ik dankbaar gebruik gemaakt. De computer assistentie van het secretariaat en met name van Lydie Coenegracht was onmisbaar. Misschien heb ik jullie achteraf gezien inhoudelijk te weinig bij het onderzoek betrokken, maar mijn ei kon ik in ieder geval bij jullie kwijt. Mijn kamer- en tevens lotgenoot Anke Oosterman wil ik hierbij in het bijzonder bedanken.

Verschillende mensen hebben een belangrijke rol gespeeld in de periode waarin de interviews werden afgenomen. In de eerste plaats de patiënten, artsen en verpleegkundigen die bereid waren mij te woord te staan. Om calamiteiten te voorkomen heeft Pim Assendelft er voor gezorgd dat kopieën werden gemaakt van de tientallen cassettebandjes en Monique Latour heeft mij enorm geholpen met het uittypen van de interviews.

Gezien mijn belangstelling voor de kwalitatieve onderzoeksmethoden waren de bijeenkomsten van de werkgroep symbolisch interactionistische onderzoeksmethoden bijzonder leerzaam. Bovendien gaven zij mij het gevoel dat ik op de goede weg was.

De Delphi-methode had ik niet kunnen toepassen zonder de medewerking van de 27 zeer gemotiveerde panelleden die zich keurig hielden aan het strakke tijdsschema. Bij de verwerking van de gegevens en de presentatie van de nieuwe vragenlijsten was de steun van Gregor Franssen van het Memic onmisbaar. Gregor, het was een gezellige en succesvolle samenwerking. Veel dank ook voor de laatste correcties van het manuscript. 
De leden van de beoordelingscommisie dank ik voor hun prikkelende kritiek waardoor het proefschrift aan waarde gewonnen heeft.

Mijn huisgenoten van de Heggenstraat 5 zorgden voor een goede thuisbasis. Het is inmiddels welbekend dat ik niet alleen door de lokatie maar ook door de sfeer in dit (studenten)huis in al die jaren niet weg te branden was.

Vrienden en vriendinnen hebben een zeer belangrijke rol gespeeld bij het verwerken van teleurstellingen en het vieren van heugelijke feiten. Het zou te ver gaan om hier iedereen bij naam te noemen. Een uitzondering wil ik maken voor Djoeke van Dale, Bart Koes en Frank van Dorsten. Jullie zorgen niet alleen voor de emotionele steun, maar hielpen me ook rationeel een eind verder op weg.

Mijn vriend Frank Huele heeft de afgelopen jaren veelal op afstand doch met nauwe betrokkenheid en vol vertrouwen het onderzoeksproces gevolgd. Zijn telefoontjes deden soms wonderen...

Mijn ouders hebben mij destijds zeer nieuwsgierig gemaakt voor allerlei verschijnselen om me heen en hebben uren geïnvesteerd in boeiende discussies. Kijk, dit komt er nou van! 


\section{CURRICULUM VITAE}

Renata Klop werd op 26 november 1960 in Amsterdam geboren. Na het doorlopen wan de lagere school en gedeelte van de middelbare school in Brussel, behaalde zij in 1980 het VWO diploma op het Stedelijk Lyceum te Maastricht. Vanaf 1980 tot 1984 studeerde zij aan de Rijksuniversiteit Limburg Gezondheidswetenschappen met als afstudeerrichting Verplegingswetenschap. Tijdens de laatste twee jaren van haar studie was zij student-assistent bij de vakgroep medische psychologie. Na het behalen van haar doctoraal diploma combineerde zij een eenjarige onderzoekersopleiding aan dezelfde universiteit met de functie van onderzoeker bij het Instituut Verplegingswetenschap te Utrecht.

In november 1985 werd zij aangesteld als wetenschappelijk assistent bij de vakgroep Gezondheidsrecht van de Rijksuniversiteit Limburg binnen het deelproject continuiteit van zorg. Gedurende een periode van vier jaar specialiseerde zij zich enerzijds op de problematiek rondom de verwijzing en het ontslag van patiënten in en uit het ziekenhuis, anderzijds op de toepassing van kwalitatieve onderzoeksmethoden. Sinds 1986 is zij lid van de onderzoeksgroep symbolisch interactionistische onderzoeksmethoden van de werkgemeenschap Sociaal Methodologisch Onderzoek. 